\title{
LOCA Simulation in the NRU Reactor
}

Materials Test - 1

Prepared by G. E. Russcher, R. K. Marshall, G. M. Hesson, N. J. Wildung, W. N. Rausch, L. L. King, C. L. Wilson, L. J. Parchen, B. J. Webb, W. D. Bennett, C. L. Mohr

Pacific Northwest Laboratory

Operated by

Battelle Memorial Institute

Prepared for

U.S. Nuclear Regulatory

Commission 


\title{
NOTICE
}

This report was prepared as an account of work sponsored by an agency of the United States Government. Neither the United States Government nor any agency thereof, or any of their employees, makes any warranty, expressed or implied, or assumes any legal liability or responsibility for any third party's use, or the results of such use, of any information, apparatus product or process disclosed in this report, or represents that its use by such third party would not infringe privately owned rights.

\author{
Avàilable from \\ GPO Sales Program \\ Division of Technical Information and Document Control \\ U. S. Nuclear Regulatory Conmission \\ Washington, D. C. 20555 \\ Printed copy price: $\$ 6.00$
}

and 
NUREG/CR-2152

PNL-3835

Vol. 1

R3

\section{LOCA Simulation in the NRU Reactor}

Materials Test - 1

Manuscript Completed: August 1981

Date Published: October 1981

Prepared by

G. E. Russcher, R. K. Mershall, G. M. Hesson, N. J. Wildung, W. N. Rausch,

L. L, King, C. L. Wilson, L. J. Parchen, B. J. Webb, W. D. Bennett, C. L. Mohr

Pacific Northwest Laboratory

Richland, WA 99352

\section{Prepared for}

Division of Accident Evaluation

Office of Nuclear Regulatory Research

U.S. Nuclear Regulatory Commission

Washington, D.C. 20555

NRC FIN B2277 

SUMMARY

A pressurized water reactor loss-of-coolant accident (LOCA) simulation test program is being conducted in the National Research Universal (NRU) Reactor to evaluate the thermal-hydraulic and mechanical deformation behavior of a full-length fuel rod bundle. The last three phases of a LOCA--heatup, reflood, and quench--are performed in situ using nuclear fissioning to simulate the low-leve1 decay power during a LOCA.

This document reports the data and initial results from the second experiment of the LOCA program. The first experiment was a prototypic thermalhydraulic (PTH) test series using parametric combinations of reflooding delay times and reflooding rates to evaluate the thermal-hydraulic characteristics of simulated LOCA's. The first materials test experiment (MT-1) used a selected set of LOCA test parameters taken from PTH-110 to produce a peak fuel cladding temperature of $1148 \mathrm{~K}\left(1607^{\circ} \mathrm{F}\right)$, and to rupture test fuel rods. Although coplanar ballooning, fuel rupture, and fuel dispersal were evident after the test, the reflood coolant quenched the test fuel bundle somewhat faster than the companion PTH-110 test fuel, which did not deform or rupture.

Graphical data and photographic information present the preliminary thermal-hydraulic, mechanical, and neutronic results of the MT-1 experiment. These results are compared to measured data from the earlier PTH-110 test and to analytic predictions from several computer codes designed to model nuclear fuel rods under transient LOCA conditions. Fuel rod mechanical deformation and rupture effects are summarized, but data will be reported in a subsequent document . 



\section{ABSTRACT}

A simulated loss-of-coolant accident was performed with a full-length test bundle of pressurized water reactor fuel rods. This second experiment of the program produced peak fue $1 \mathrm{cladding}$ temperatures of $1148 \mathrm{~K}\left(1607^{\circ} \mathrm{F}\right)$ and resulted in six ruptured fuel rods. Test data and initial results from the experiment are presented here in the form of photographs and graphical sumaries. These results are also compared with the preceding prototypic thermal-hydraulic test results and with computer model test predictions. 


\section{ACKNOWLEDGMENTS}

The authors would like to thank the Chalk River Nuclear Laboratories (CRNL) for their assistance in performing this test series. A special acknowledgment is due to CRNL staff members--D. T. Nishimura, P. E. Kelly, S. Z. Hart, I. D. Ross, J. W. Logie, C. A. Herriot, and B. DeAbreu, who made major contributions in keeping this work on schedule.

The assistance of R. Van Houten, NRC/RSR/FBR, Program Manager is also acknowledged for providing helpful directives to the program.

The authors would also like to thank B. Breizy for preparation of this manuscript, and J. 0. Barner for careful review and editorial guidance. 


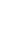




\section{CONTENTS}

SUMMARY

1.0 INTRODUCTION

1.1 TEST SCOPE AND OBJECTIVES

1.2 APPLICABILITY OF RESULTS . . . . . . . . . . 2

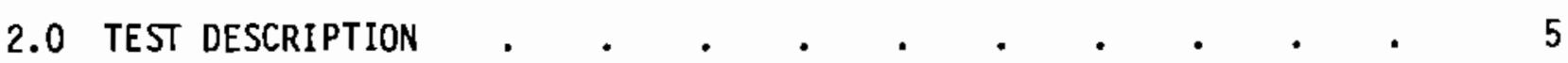

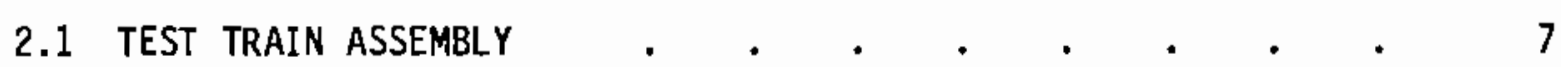

2.2 MT-1 OPERATION $\quad$. . . . . . . . . . . . 10

3.0 TEST CONDITIONS AND RESULTS . . . . . . . . . . . . . 15

3.1 TEST ASSEMBLY TEMPERATURES . . . . . . . . . . . 15

3.1.1 Preconditioning Test Assembly Temperatures $\quad$. $\quad 15$

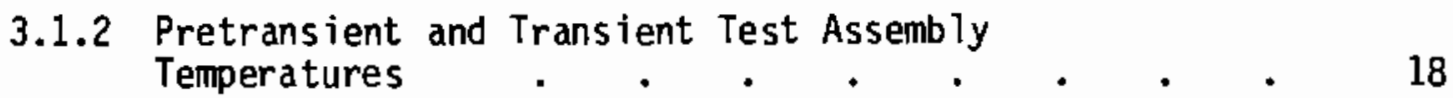

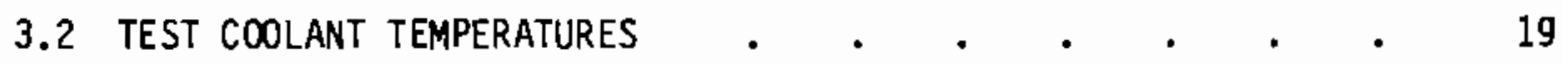

3.2.1 Preconditioning Outlet Temperatures . $\quad . \quad$. 19

3.2.2 Pretransient and Transient Outlet Temperatures . . 19

3.2.3 Steam Probe Temperatures . . . . . . . 20

3.3 PONER COUPLING $\quad$ - . . . . . . . . . . . . . 20

3.3.1 Test Assembly Preconditioning . . . . . . 20

3.3.2 Test Assembly Pretransient . . . . . . . 21

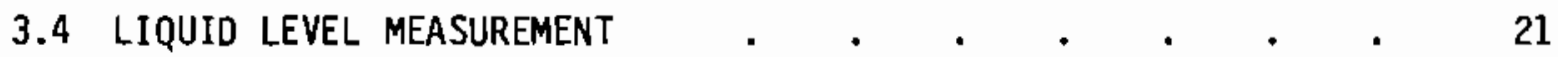

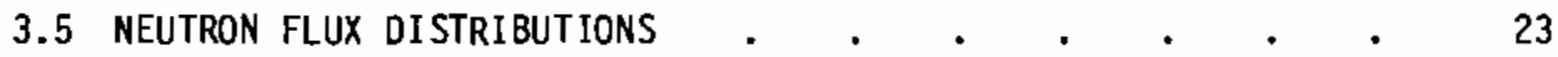

3.5.1 Preconditioning Neutron Flux . . . . . . 23

3.5.2 Pretransient and Transient Neutron Flux . . . 25 


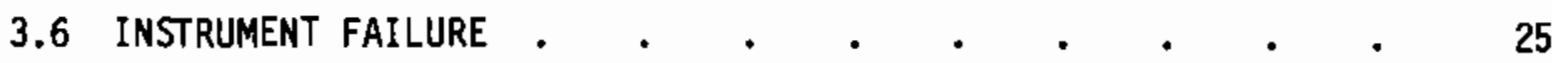

3.6.1 Final Test Assembly Pretest Instrument
Conditions

3.6.2 Instrument Failures $\quad$ - . . . . . . 27

3.7 REFLOOD FLOW MEASUREMENTS . . . . . . . . . . . . 28

3.8 FUEL ROD PRESSURE.$\quad$. . . . . . . . . . . 30

3.8.1 Pressure Switches . . . . . . . . 30

3.8.2 Pressure Transducers . . . . . . . . . 31

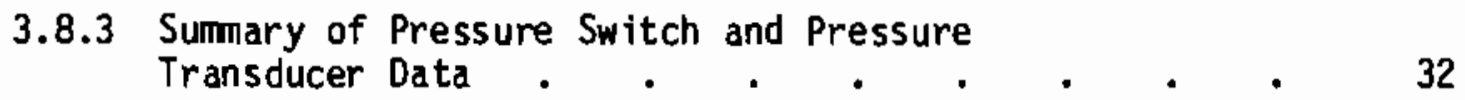

4.0 ANALYSIS AND COMPARISON OF TEST DATA $\quad . \quad$. . . . . . . . . 35

4.1 COMPARISON OF THE PTH-110 TEST AND THE MT-1 TEST . . . . 35

4.2 COMPARISON OF DATA WITH COMPUTER CODE PREDICTIONS . . . 38

5.0 VISUAL AND PHOTOGRAPHIC EXAMINATION $\quad . \quad \ldots \quad$. $\quad . \quad$. $\quad$. 45

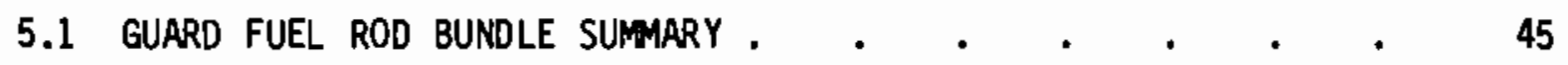

5.2 TEST FUEL ROD BUNDLE SUMMARY . $\quad . \quad$. . . . . . . . . . 45

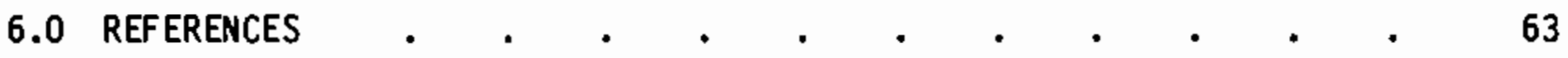

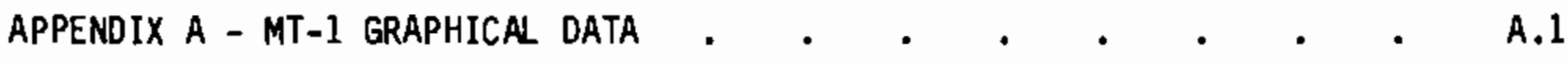

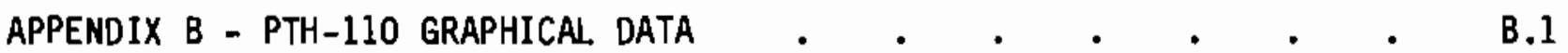

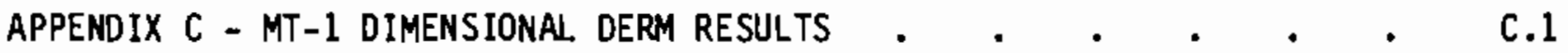




\section{FIGURES}

1.1 Cross Section of Test Assembly, Pressure Tube, Liner Tube, and Instrumentation Channel Identification . . . . 3

2.1 NRU Reactor Core Configuration . . . . . . . 6

2.2 Schematic of the NRU LOCA Test Train . . . . . 8

2.3 Instrumentation at Levels 1 Through 3 . . . . . 11

2.4 Instrumentation at Levels 4 Through 12 . . . . . . 12

2.5 Instrumentation at Levels 13 Through 21 . . . . . . 13

3.1 Instrumentation for Materials Test-1 . . . . . 17

3.2 Change in Fluid Level During the Transient . . . . 22

3.3 Neutron Flux In and Outside the MT-1 Test Assembly . . . 24

4.1 Comparison of Peak Fuel Rod $\mathrm{Cl}$ adding Temperatures
at Level 15 for Tests $M T-1$ and PTH-110 . . . . . 36

4.2 Comparison of Peak Guard Fuel Rod Cladding Temperatures

4.3 Comparison of Predictions and Guard Fuel Rod Cladding

Temperature Measured at Leve1 13 .

4.4 Comparison of Predictions with Guard Fuel Rod Cladding

Temperature Measured at Level $15 . . .540$

4.5 Comparison of Predictions with Guard Fuel Rod Cladding

Temperature Measured at Level 17 . . . . . . 41

4.6 Comparison of TRLMP-FLECHT Predictions with MT-1 Guard
Fuel Rod Cladding Temperature at Level 13 . . . . 42

4.7 Comparison of TRLMP-FLECHT Predictions with MT-1 Guard

Fuel Rod Cladding Temperature at Level 15 . . . . . 43

5.1 External Shroud and Inlet Nozzle . . . . . . . 47

5.2 External Shroud and Locking Clip Near Level 13 . . . 48

5.3 Bottom Third of Open Test Assembly--Guard Fuel Rods
in Position 
5.4 Center Third of Open Test Assembly--Guard Fuel Rods

5.5 Side View of Guard Fuel Rods at Lower Tie Plate-$\mathrm{Z}=0.0$ Reference

5.6 Side View of Guard Fuel Rods Where Internal Test

Fuel Rods Ruptured . . . . . . . . . 52

5.7 Side View of Test Assembly Upper End With Instrument Hard Lines. . . . . . , . . . .

5.8 Lower Third of Test Fuel Rod Bundle--Guard Fuel Rod Bundle Removed . . . . . . . . . 54

$5.9 \quad$ Center Third of Test Fuel Rod Bundle and Rupture Region . . $\quad 55$

5.10 Side View of Test Fuel Rods at the Lower Tie Plate-$\mathrm{Z}=0.0$ Reference. .5 .5 .56$

5.11 Side View of Test Fuel Rods With Fuel Pellet Fragments . . 57

5.12 Side View of Test Fuel Rods at Rupture Region . . . . 58

5.13 Top View of Test Fuel Rods at the Lower Tie Plate . . . 59

5.14 Top View of Test Fuel Rods at the Fuel Rupture Region . . 60

5.15 Closeup of Test Fuel Rod Rupture Region . . . . . 61

5.16 Closeup of Test Fuel Rod Rupture Region . . . . . . 62 


\section{TABLES}

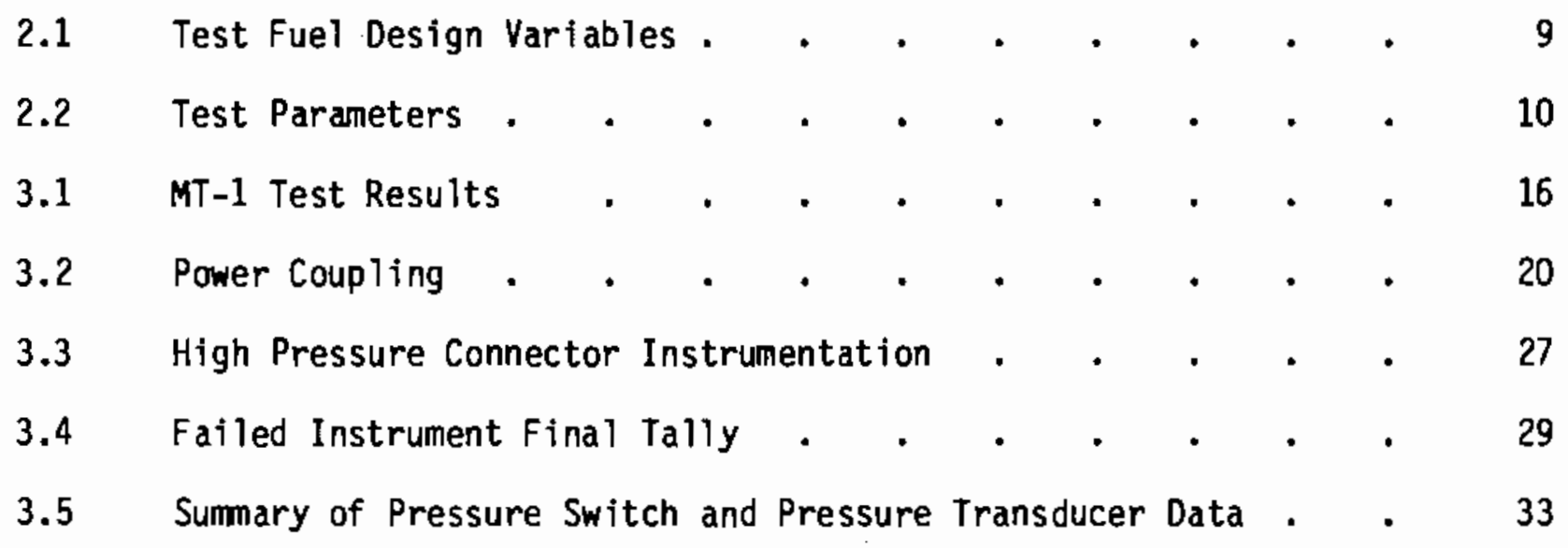




\subsection{INTRODUCTION}

A loss-of-coolant accident (LOCA) simulation test program is being conducted in the National Research Universal (NRU) reactor at Chalk River Nuclear Laboratories ${ }^{(a)}$ by Pacific Northwest Laboratory (PNL). (b) The program is sponsored by the Fuel Behavior Research Branch of the U.S. Nuclear Regulatory Commission (NRC) to evaluate the thermal-hydraulic and mechanical deformation behavior of a full-length, $3 \%$ enriched pressurized water reactor (PWR) fuel rod bundle during heatup, reflood and quench phases of a LOCA. The tests are driven by low-level fission heat and simulate the decay heat temperature gradients in the fuel and cladding typical of a LOCA (Hann 1979).

The test program is composed of 1) a series of prototypic thermalhydraulic (PTH) tests using a single test assembly, and 2) five subsequent cladding material tests (MT) using different test assemblies for each test. The results of the thermal-hydraulic test series have been reported (Mohr et a). 1981). The series consisted of 28 tests using unpressurized fuel rods that deformed but did not dilate or rupture during the tests. The results of that test series provided a reference for evaluating the quenching characteristics of Zircaloy-clad fuel rods.

This report provides the results of the first of several planned cladding material tests (MT-1). The MT-1 test uses pressurized test fuel rods and concentrates on evaluating not only fuel cladding ballooning and rupture due to a LOCA, but also the thermal-hydraulic effects of resultant flow blockage. The MT-1 test duplicated the reflood rate and delay time used in test PTH-110 of the thermal-hydraulic test series. The comparison of MT-1 and PTH-110 data shows the relative effects of rupture and blockage on bund le heat transfer characteristics.

(a) Operated by Atomic Energy of Canada, Ltd. (AECL).

(b) Operated for the U.S. Department of Energy (DOE) by Battelle Memorial Institute. 


\subsection{TEST OBJECTIVES AND SCOPE}

The primary objective of the MT-1 test was to determine the effects of fuel cladding dilatation and rupture on heat transfer with in a full-length LWR fuel bund le during a LOCA, as compared to the PTH-110 test series. The test conditions were selected to provide peak cladding temperatures of up to $1172 \mathrm{~K}$ $\left(1650^{\circ} \mathrm{F}\right)$ with a temperature time history that would permit the cladding to fail by a creep/creep-rupture failure process.

A secondary objective was to determine the fuel rod rupture time during the simulated LOCA experiment. Current fuel rod rupture computer models were used to predict fuel cladding rupture. Test results are compared here with predictions based on computer modeling of fuel behavior during the measured test operating conditions.

The 11 pressurized test fuel rods expected to rupture were assembled in the cross-sectional configuration of a cruciform, shown in Figure 1.1. Twenty outer guard fuel rods provided an adiabatic thermal boundary and were designed not to fail but to be reused with the test train in subsequent materials tests. Preliminary LOCA and fuel failure test results are summarized here; detailed postirradiation examination data will be provided in the test program final report or possibly subsequent topical reports.

\subsection{APPLICABILITY OF RESULTS}

The MT-1 test results provide the first ful1-length nuclear heated cladding rupture data. The test conditions are the most prototypic of any test performed to date with the power levels, temperature distributions, and heat fluxes similar to current PWR conditions. The postirradiation observations of the fuel bund le have shown that the fuel cracking and fuel relocation are probably typical of commercial light water reactor (LWR) fuel. This means that the resulting azimuthal cladding temperature variations and the resulting failure strains and blockage zones are also typical of LWR LOCA conditions. 


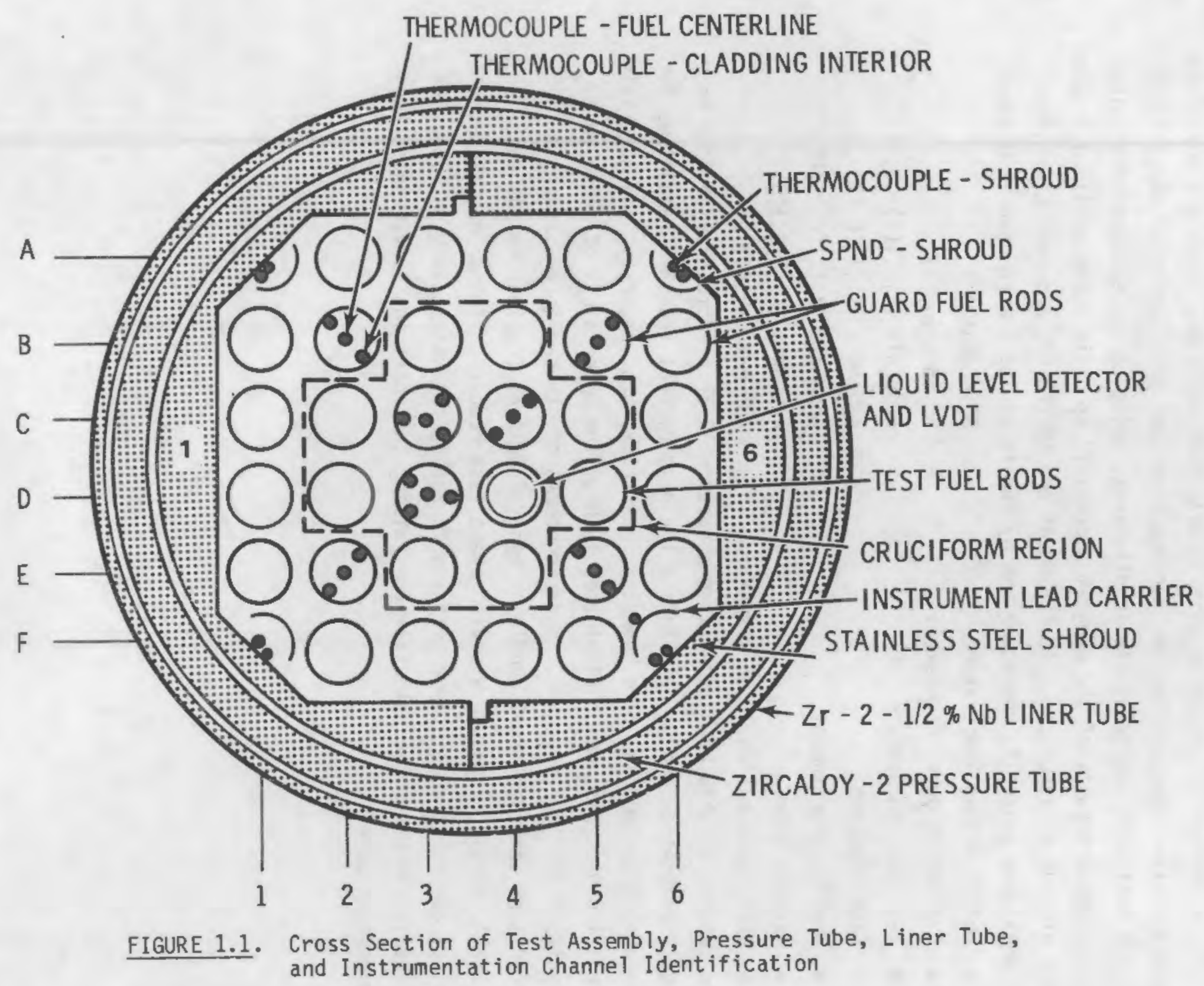


The data will be used to assess various calculational models for reactor safety analyses and conclusions derived from the large series of electrically heated tests and smaller scale in-pile tests being conducted elsewhere. The experimental results of the program address 17 specific items outlined in the Code of Federal Regulations 10 CFR 50.46 and 10 CFR 50, Appendix K. These 17 areas are generally characterized by the following 7 more general groups:

- Peak Cladding Temperature

50.46 (b) (1)

- Evaluation Model Assessment 50.46 (b) (5) (2)

- Swelling and Rupture Appendix $(K)(I)(B)$

- Flow Blockage Appendix $(K)(I)(C)(2)$

- Droplet Entrainment Appendix $(K)(I)(C)(1)(C)(2)$

- Reflood Rate Appendix $(K)(I)(D)(3)$

- Refill and Reflood Heat Transfer Appendix $(K)(I)(D)(5)$

The results of this LOCA simulation program will be used to provide data for model calibration and to help define the primary heat transfer mechanisms for new analytical models. The geometry, mass flux, heat capacity, and materials are all prototypic, which eliminates much of the uncertainty of prior test results from other programs. Major concerns of other programs, such as the effects of length of fuel bundle or type of heating (nuclear versus electrical), should be answerable with these test results. The major LWR technology contribution of these tests is to reduce the uncertainty on licensing criteria and offer the potential for raising the operating limits on certain commercial LWRs. 


\subsection{TEST DESCRIPTION}

The MT-1 experiment was designed to evaluate the effects of deformation and rupture of the fuel cladding on the cooling characteristics of PWR fuel during a LOCA. The test parameters were selected to provide peak fuel cladding temperatures of up to $1172 \mathrm{~K}\left(1650^{\circ} \mathrm{F}\right)$ with sufficient time at temperature to allow swelling and rupture of the cladding in the high $\alpha / \alpha+\beta$ microstructure range. The test operating variables of reflood rate and delay time were selected to duplicate PTH-110. Because PTH-110 used unpressurized rods and thus the rods did not dilate or rupture, the comparison of MT-1 test data with PTH-110 test data shows the incremental effects of dilatation and rupture on bundle heat transfer. The MT-1 experiment was composed of 3 test phases: preconditioning, pretransient, and the simulated LOCA transient. These three test phases all utilized position L-24 of the NRU reactor (Figure 2.1).

The preconditioning test phase was conducted at an average fuel rod power of about $18.7 \mathrm{~kW} / \mathrm{m}(5.7 \mathrm{~kW} / \mathrm{ft})$, with the U-2 loop providing water cooling. Three short runs at full power were made to permit the fuel to crack and relocate with in the fuel cladding in a prototypic manner. System pressure was held at $8.62 \mathrm{MPa}$ (1250 psi).

The pretransient phase was conducted with steam cooling (provided by the $\mathrm{U}-1$ loop) at a mass flow rate of about $0.378 \mathrm{~kg} / \mathrm{s}(3000 \mathrm{lbm} / \mathrm{hr})$ and an average fuel rod power of $1.24 \mathrm{~kW} / \mathrm{m}(0.38 \mathrm{~kW} / \mathrm{ft})$. This operation brought the test assembly up to the final pretransient power with a cladding temperature of $727 \mathrm{~K}\left(850^{\circ} \mathrm{F}\right)$ and a system back pressure controlled at $0.276 \mathrm{MPa}$ (40 psia).

In the transient phase, the test assembly (and fuel cladding) was permitted to heat up in stagnant steam. At a preselected delay time (32s), reflood water was introduced at a preselected rate $[0.051 \mathrm{~m} / \mathrm{s}(2 \mathrm{in} / \mathrm{s})]$. At the time when either the test section was reflooded or all of the test assembly thermocouples (TCS) were quenched, the test was terminated and the NRU reactor was tripped. The system back pressure was controlled at $0.276 \mathrm{MPa}$ (40 psia) during this portion of the test also. 
SOUTH

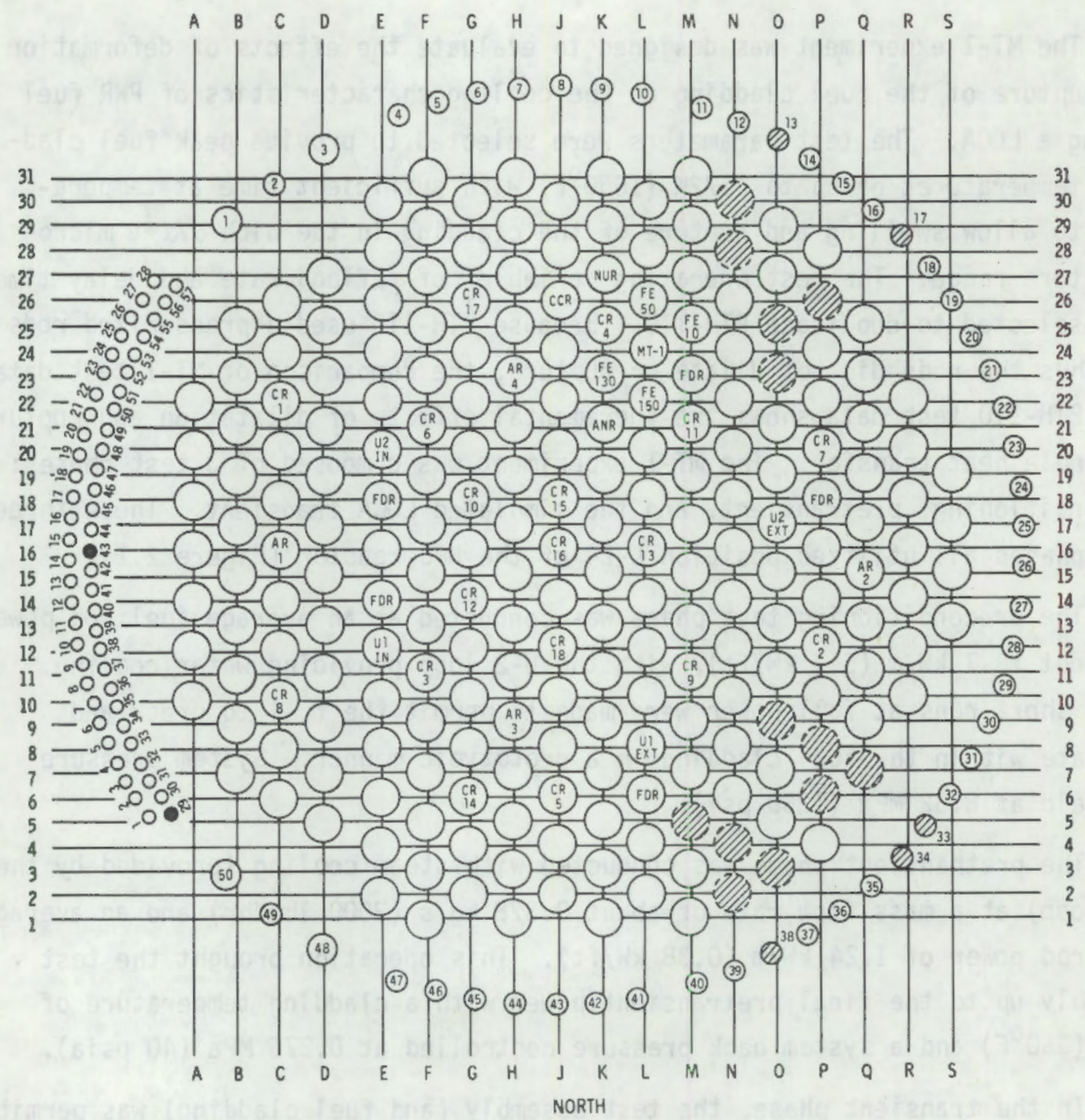

CR CONTROL ROD

AR ADJUSTER ROD

FDR FLUX DETECTOR ROD

$U-1$ IN
$U-2$ IN DOWN FLOW CHANNEL-DUMMY FUEL

CCR COBALT CARRIER ROD

NUR NATURAL URANIUM ROD

ANR ALUMINUM NITRIDE ROD

FE 50 FUEL ELEMENT - 50 MWO BURNUP FE 10 FUEL ELEMENT - 10 MWD BURNUP

$U-1$ EXT
$U-2$ EXT UP FLOW CHANNEL - DUMMY FUEL

FE 130 FUEL ELEMENT - 130 MWD BURNUP

FE 150 FUEL ELEMENT - 150 MWD BURNUP

STANDARD LATTICE POSITION

BLOCKED CHANNEL-NOT FUELED

FIGURE 2.1. NRU Reactor Core Configuration 


\subsection{TEST TRAIN ASSEMBLY}

A schematic of the overall test train is depicted in Figure 2.2. The total length of the test train, including the head closure, hanger tube, and the test assembly, was $9.18 \mathrm{~m}$ ( $30 \mathrm{ft}, 1.5 \mathrm{in.}$ ). The closure region provided the primary pressure boundary and included penetrations for 183 instrumentation leads. The hanger tube was used to suspend the test bundle and shroud from the head closure plug, and instrument leads were attached to the hanger to protect them during transport and testing. The shroud supported the fuel bundle; it served as a protective liner during the experiment and transfer operations and provided proper flow distribution during various stages of the experiment. The stainless steel (SS) shroud consisted of two halves clamped together at $17.78-\mathrm{cm}(7-\mathrm{in.})$ intervals and attached at the end fittings. The split shroud design made it possible to remotely disassemble, examine, and reassemble the test train underwater. The shroud and test assemblies were approximately $4.27 \mathrm{~m}(14 \mathrm{ft})$ long and were highly instrumented. The Experiment Operations Plan (Russcher et al. 1981) contains a detailed instrumentation listing.

The fuel bundle consisted of a $6 \times 6$ segment of a $17 \times 17$ PWR design with the four corner rods removed (Figure 1.1). This provided a basic test array of $6 \times 6-4$ or 32 rods. The outer row of 20 rods, including the corner rods of the next inner ring, were not pressurized and served as guard fuel rods (heaters) during the test. The test section consisted of 11 pressurized fuel rods (Table 2.1) and 1 instrument tube arranged in a cruciform pattern. The 11 test fuel rods were pressurized with helium to $3.2 \mathrm{MPa}$ ( $465 \mathrm{psia}$ ) to provide the internal cladding stress condition that simulated a PWR rod at beginning-oflife. This pressurization caused simulated LOCA fuel rod rupture while minimizing the released radioactive fission product inventory.

The test train instrumentation included self-powered neutron detectors (SPND) (24), thermocouples (TC) $(114)$, steam probes (SP)(20), pressure transducers $(P T)(2)$, pressure switches (PS)(9), and for this test, a liquid level detector (LLD) float tube with a linear variable differential transformer (LVDT) sensor in the instrument tube location 4D. The LLD design was based on the buoyant principle, with a float supported by a spring and an LVDT to 


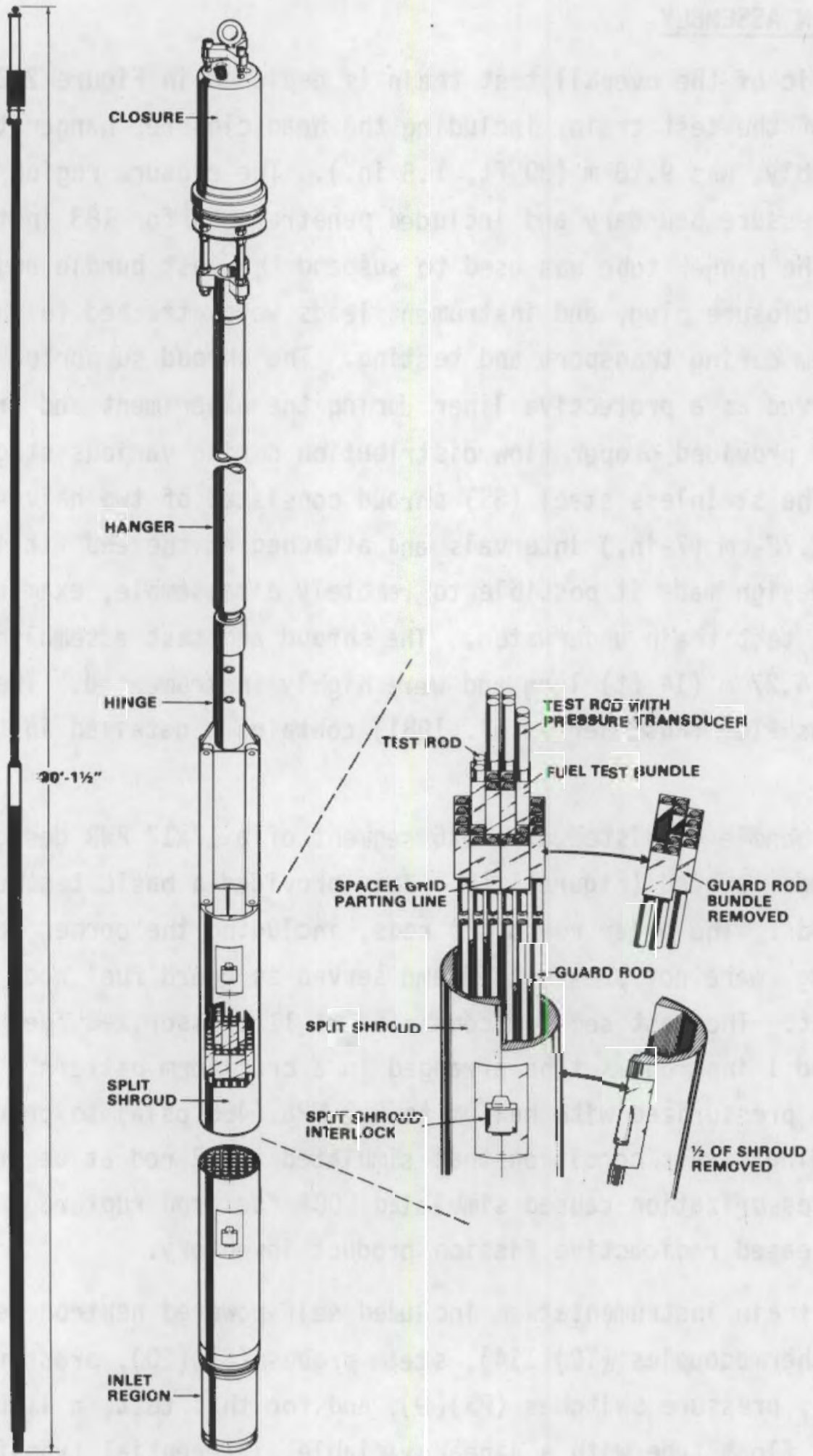

FIGURE 2.2. Schematic of the NRU LOCA Test Train 


\section{TABLE 2.1. Test Fuel Design Variables}

$\begin{array}{lll}\text { Cladding Material Specification } & =\text { Zircaloy-4 } \\ \text { Cladding Outside Diameter (OD) } & =0.963 \mathrm{~cm}(0.379 \mathrm{in.}) \\ \text { Cladding Inside Diameter (ID) } & =0.841 \mathrm{~cm}(0.331 \mathrm{in.}) \\ \text { Pitch (rod to rod) } & =1.275 \mathrm{~cm}(0.502 \mathrm{in.}) \\ \text { Fuel Pellet Diameter } & =0.826 \mathrm{~cm}(0.325 \mathrm{in.}) \\ \text { Fuel Pellet Length } & =0.953 \mathrm{~cm}(0.375 \mathrm{in.}) \\ \text { Active Fueled Length } & =365.76 \mathrm{~cm}(144 \mathrm{in.}) \\ \text { Total Shroud Length } & =423.1 \mathrm{~cm}(170.125 \mathrm{in.}) \\ \text { Helium Pressurization } & =3.2 \mathrm{MPa}(465 \mathrm{psia})\end{array}$

measure the relative displacement. These instruments were monitored on a real-time basis with the Data Acquisition and Control System (DACS). The recorded data characterized the temperature, power, and operating history of the MT-1 test train and provided a record of when cladding rupture occurred and its thermal-hydraulic effects.

TC measurements provided the main source of the thermal-hydraulic data. Local coolant temperatures were determined from the steam probe (SP) thermocouples. TCs were also attached to the inside of the cladding surface to measure azimuthal temperature variations. These cladding TCS were spot welded to the interior cladding surface and permitted the monitoring of the cladding temperature without interference from fuel pellet chips or unintentional TC relocation.

SPNDs provided relative neutron power measurements within the fuel bundle during steady-state operation. These neutron detectors also detected coolant density variations associated with the reflooding coolant front that was present during the reflood phase of the transient.

Each test fuel rod had a pressure transducer or a pressure switch attached to the top end cap. Pressure transducers monitored the internal pressure for test fuel rods $3 C$ and $5 \mathrm{C}$, and pressure switches identified the depressurization time for the plenums of other test fuel rods. 
Instrumentation was located at 22 elevations along the axial length of the test train assembly. Figure 2.3 defines the axial elevation of each of these levels and Figures 2.3, 2.4, and 2.5 show the associated instruments at each level. Additional detail is provided on the blue prints referenced on Figure 2.3, and the nomenclature used to identify the instrumentation channels is also noted in Figure 2.3.

\subsection{MT-1 OPERATION}

The materials test was performed to match as nearly as possible the prototypic thermal-hydraulics test PTH-110. The boundary conditions that were most closely matched were steam flow rate, reflood rate, reflood temperature, reflood delay time, and average linear rod power. In addition, the initial fuel cladding temperature (at the beginning of the transient) and the temperature difference between inlet and outlet steam flow were adjusted to match PTH-110. Table 2.2 lists the test data measured in PTH-110 and predicted for MT-1.

TABLE 2.2. Test Parameters

\begin{tabular}{|c|c|c|}
\hline Test $P$ arameter & $\begin{array}{l}\text { Predicted for } \\
\text { MT-1 }\end{array}$ & $\begin{array}{l}\text { Test Data } \\
\text { PTH-110 } \\
\end{array}$ \\
\hline $\begin{array}{l}\text { Reflood Rate, } \\
\mathrm{m} / \mathrm{s} \text { (in./s) }\end{array}$ & $\begin{array}{l}0.048 \\
(1.9)\end{array}$ & $\begin{array}{l}0.053 \\
(2.1)\end{array}$ \\
\hline Delay Time, s & 30.0 & 30.0 \\
\hline $\begin{array}{l}\text { Peak } \mathrm{Cl} \text { adding Temperature, } \\
\mathrm{K}(\mathrm{OF})\end{array}$ & $\begin{array}{l}1172 \\
(1650)\end{array}$ & $\begin{array}{l}1163 \\
(1633)\end{array}$ \\
\hline $\begin{array}{l}\text { Initial Cladding Temperature, } \\
\quad \mathrm{K}(\mathrm{OF})\end{array}$ & $\begin{array}{l}728 \\
(850)\end{array}$ & $\begin{array}{l}727 \\
(848)\end{array}$ \\
\hline $\begin{array}{l}\text { Reflood Coolant Temperature, } \\
\quad K\left(\mathrm{O}_{\mathrm{F}}\right)\end{array}$ & $\begin{array}{l}305 \text { to } 322 \\
(90 \text { to } 120) \\
(70 \text { to } 130)\end{array}$ & $\begin{array}{l}305 \text { to } 322 \\
(90 \text { to } 120)\end{array}$ \\
\hline $\begin{array}{l}\text { Average Linear Rod Power, } \\
\mathrm{kW} / \mathrm{m}(\mathrm{kW} / \mathrm{ft})\end{array}$ & --- & $\begin{array}{l}1.23 \\
(0.375)\end{array}$ \\
\hline
\end{tabular}




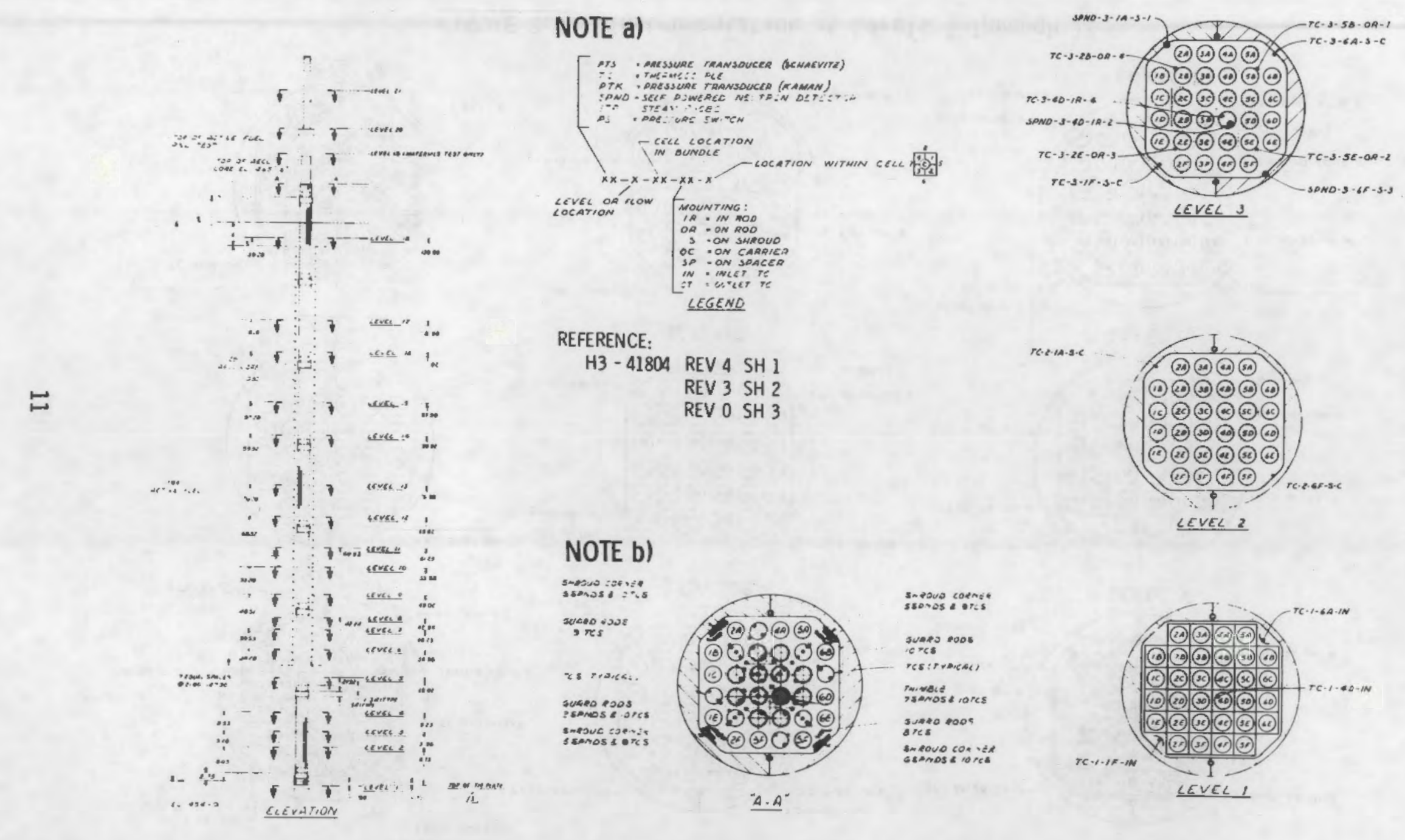

FIGURE 2.3. Instrumentation at Levels 1 Through 3 

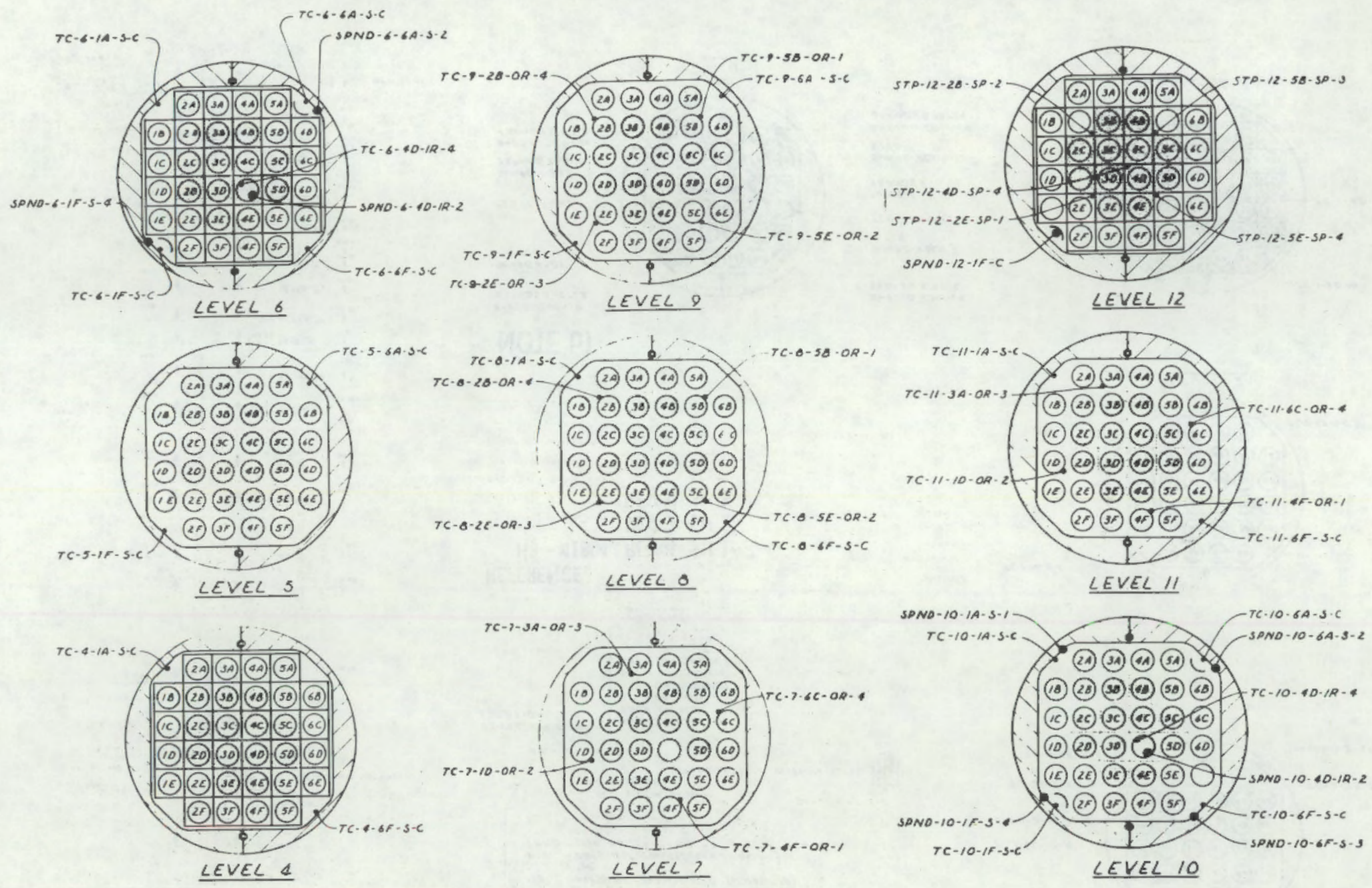

FIGURE 2.4. Instrumentation at Levels 4 Through 12 


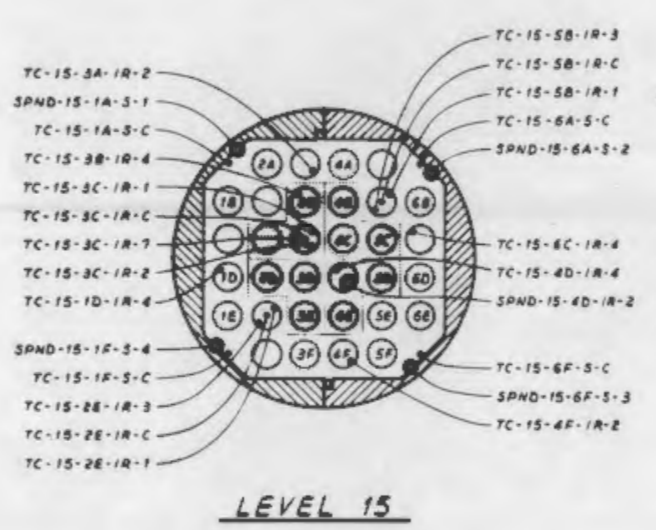

崩
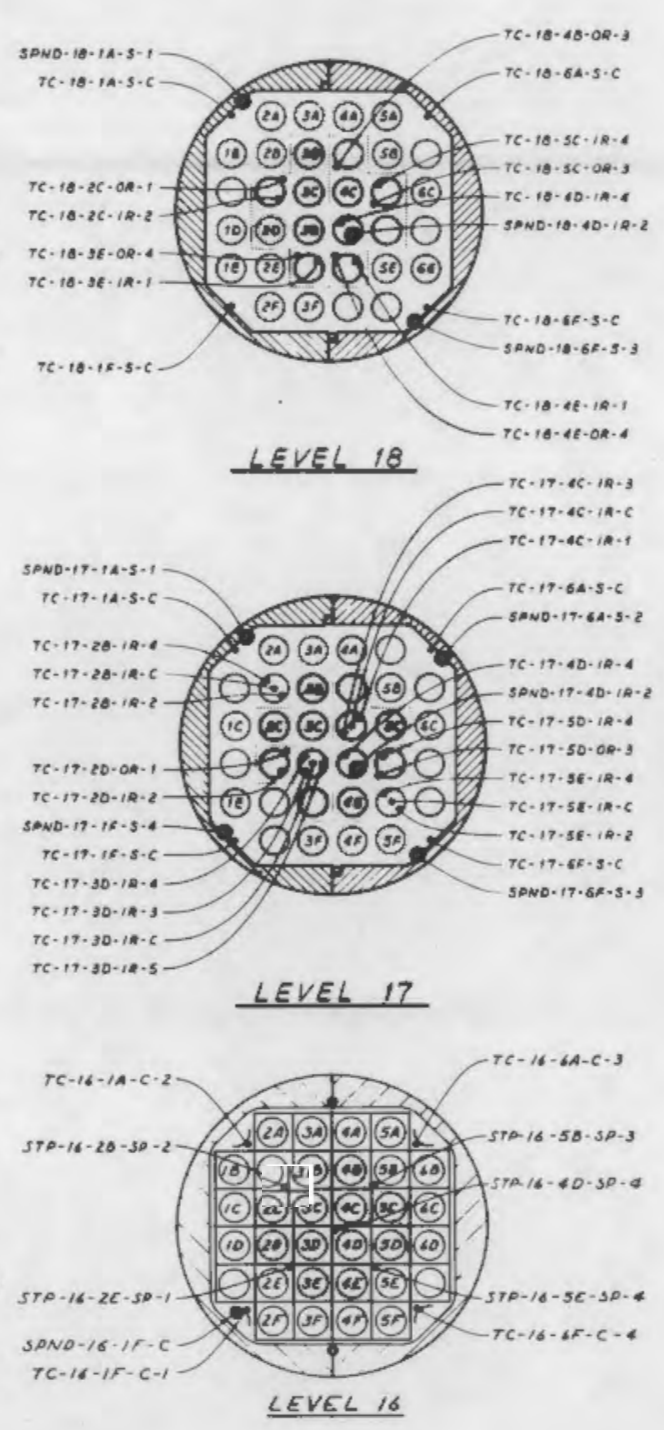
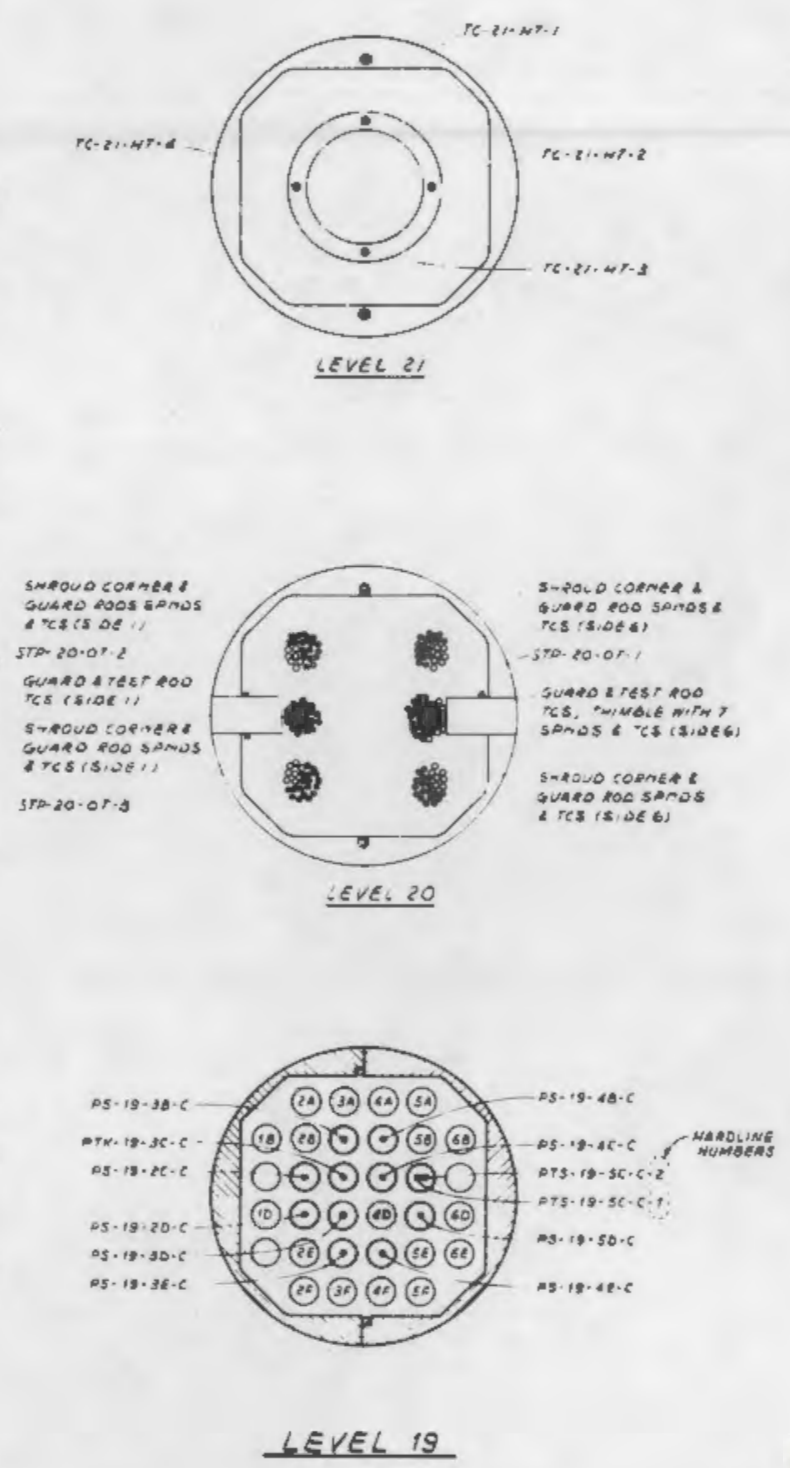

FIGURE 2.5. Instrumentation at Levels 13 Through 21 



\subsection{TEST CONDITIONS AND RESULTS}

A summary of the test conditions predicted for the MT-1 experiment is listed in Table 2.2. Test conditions achieved are described in Table 3.1, including reflood rate, reflood delay time, and peak cladding temperatures measured during the test. The peak cladding temperatures reported are those at the start of the transient (at the start of the adiabatic heatup), and the maximum temperatures measured during the transient. The peak cladding temperatures were measured by TCs on the inside surface of the fuel rods. Quench times for both the peak temperature fuel rod and the bundle are also summarized in Table 3.1 .

This section consists of summaries of the data resulting from the MT-1 experiment. In order to facilitate the use and comparison of the graphic data presented here, they are collected in the appendices. Computer-generated plots for each general section of the MT-1 data can be found in Appendix A. Comparable data plots from the PTH-110 test are repeated in Appendix B for comparison to MT-1. These graphic data are presented in similar numerical sequence (e.g., Figure A.1.1.1.1 versus Figure B.1.1.1.1). The base data for the PTH test series are reported (Mohr et al. 1980).

\subsection{TEST ASSEMBLY TEMPERATURES}

The test assembly temperatures were measured on the following components: test fuel rods, inner and outer guard fuel rods, shroud, and the instrument lead carrier. The temperature of the coolant in 5 subchannels was also measured. Temperature data for each of these locations can be found in Part 1 of Appendix A. The data for preconditioning operation are contained in Part 1.1, and the data for pretransient and transient test operations are contained in Part 1.2. The locations of the thermocouples and other instruments of the test train are shown in Figure 3.1.

\subsubsection{Preconditioning Test Assembly Temperatures}

MT-1 data were recorded during the power ascension and during the fullpower, steady-state preconditioning phase of NRU reactor operation. The average 
TABLE 3.1. MT-1 Test Results

\begin{tabular}{|c|c|c|}
\hline Test Parameter & Measured & Predicted \\
\hline Reflood Delay Time, s & 32.0 & 30.0 \\
\hline Reflood Coolant Flow Rate, m/s (in./s) & $0.053(2.1)$ & $0.048(1.9)$ \\
\hline Reflood Temperature Range, $\mathrm{K}$ ( $\left.{ }^{\circ} \mathrm{F}\right)$ & $\begin{array}{l}294 \text { to } 328 \\
(70 \text { to } 130)\end{array}$ & $\begin{array}{l}305 \text { to } 322 \\
(90 \text { to } 120)\end{array}$ \\
\hline Initial Cladding Temperature, $\mathrm{K}\left({ }^{\circ} \mathrm{F}\right)$ & $734(861)$ & $728(850)$ \\
\hline Peak Cladding Temperature, $\mathrm{K}\left({ }^{\circ} \mathrm{F}\right)$ & $1148(1607)$ & $1172(1650)$ \\
\hline Average Linear Rod Power, $\mathrm{KW} / \mathrm{m}(\mathrm{kW} / \mathrm{ft})$ & $1.24(0.38)$ & -- \\
\hline Fuel Rod Plenum Depressurization, $s$ & 60 to $95^{(c}$ & -- \\
\hline Earliest Fuel Rod Failure, s & $<60^{(a)}$ & -- \\
\hline Peak Cladding Quench Time, s & $\sim 155^{(a)}$ & -- \\
\hline Fuel Bundle Quench Time, s & & 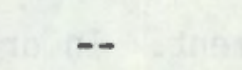 \\
\hline Fuel Rod Rupture Elevation, m (in.) & $\sim 2.0(81)^{(b)}$ & -- \\
\hline
\end{tabular}

(a) Time after beginning of transient, $t=10 \mathrm{sec}$ on historical plots in Appendix A.

(b) Above bottom of fuel column; top of the tie plate $=0.0$

axial temperature profile for the shroud is shown (see Figure A.1.1.1.1 of Appendix $A$ ) as are the individual corner channel axial temperature profiles (see Figure A.1.1.1.2). Negligible $\left[ \pm 4 K\left( \pm 8^{\circ} \mathrm{F}\right)\right]$ coolant temperature gradients across the test assembly are evident from this comparison of individual corner channel temperatures. Inlet piping temperature $27.43 \mathrm{~m}$ (1080 in.) upstream from the test assembly, the outlet region coolant temperature (Level 20), the coolant temperature at the hanger tube (Level 21), and the outlet piping temperature $8.23 \mathrm{~m}$ ( $324 \mathrm{in.}$ ) downstream from the test assembly are provided in Figure A.1.1.1.3. Intervening data (Levels 1 through 18) represent average shroud temperatures in the test assembly.

The average cladding temperatures of the guard fuel rods during preconditioning are shown in Figure A.1.1.2.1. TCS were located on both the interior (IR) and exterior (OR) of the guard fuel rod cladding, and axial temperature distributions are provided by both types of sensor. For comparison, the 


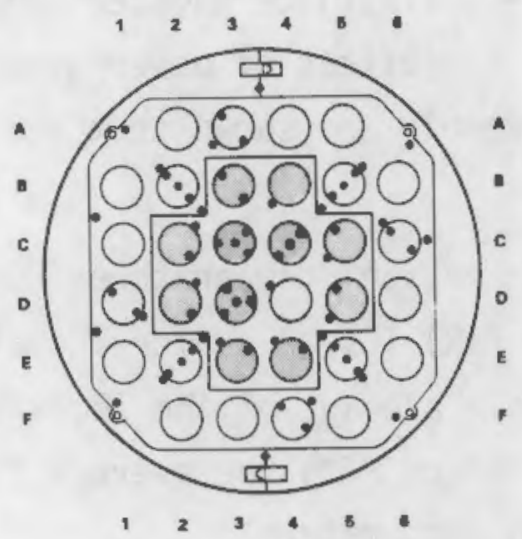

- meamocouple

- selF-pOWEREo NEUTRON Detector

PS = PRESSURE SWITCH

PTK = PRESSURE TRANSDUCER, KAMAN

PTS = PRESSURE TRANSDUCER, SCHAEVITZ

LVDT = UNEAR VARIABLE DIFFERENTIAL THANSFORMER
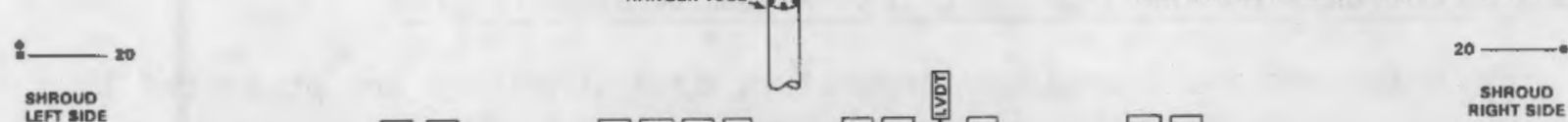

IEFT SIDE

PS PS PS PTK PS PS

PS PS PS

PTs PS

A LVEE
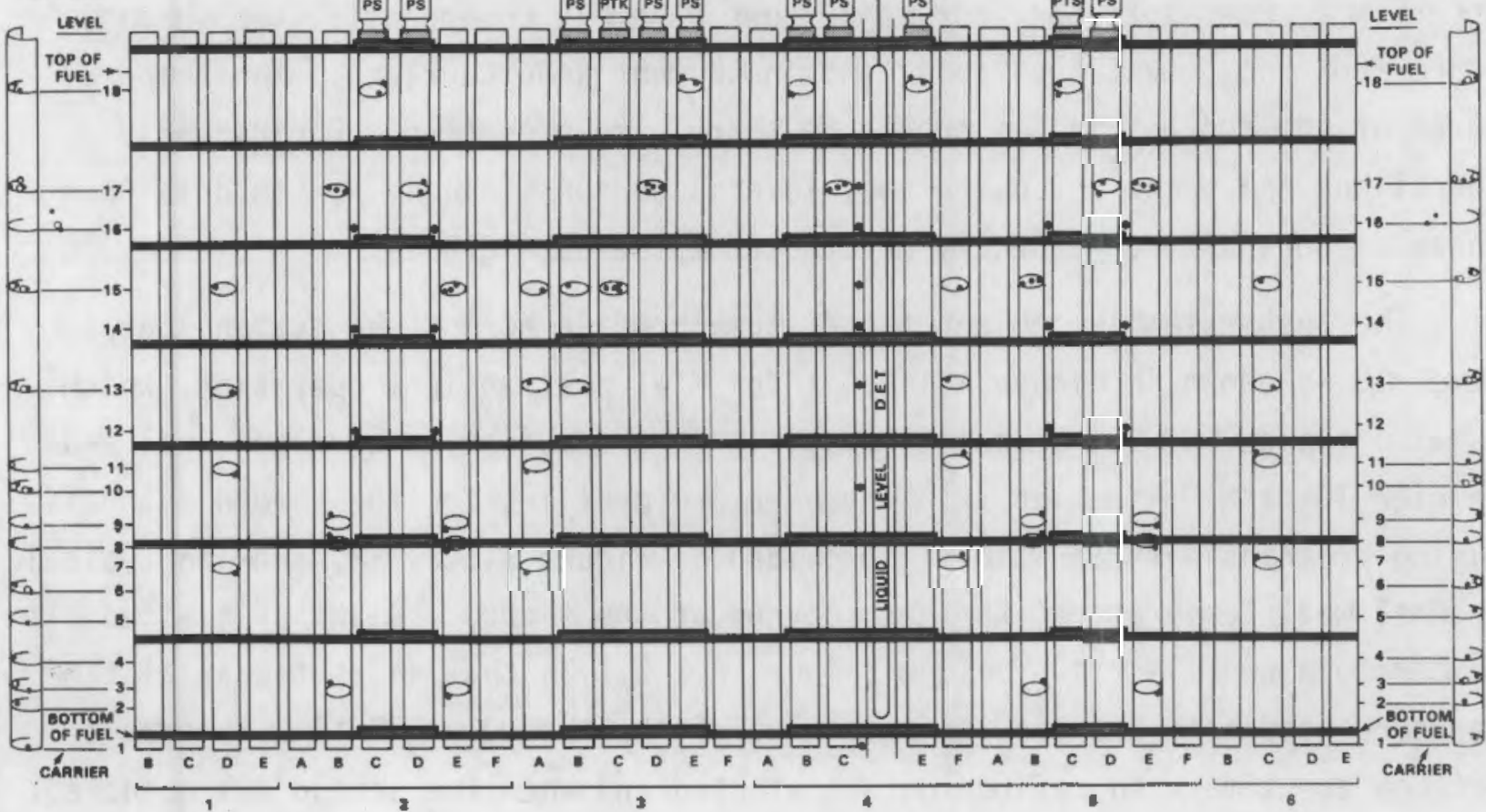

FIGURE 3.1. Instrumentation for Materials Test-1 
coolant temperatures determined by steam probes at three elevations are also included on Figure A.1.1.2.1. Data for the same type and instrument level are either averaged (Figure A.1.1.2.1) or plotted independently (see Figure A.1.1.2.2) to illustrate the effect of power gradients. Temperature gradients across the test assembly are shown at three levels. They are negligible.

Test fuel rod (cruciform region) temperatures during preconditioning were measured by several interior (IR) TCS, 2 center TCS at Level 17, and 1 Level 18 exterior (OR) TC. The probable average of the IR axial temperatures is shown in Figure A.1.1.3.1 for comparison with the average fuel center temperature and the average exterior cladding temperature.

\subsubsection{Pretransient and Transient Test Assembly Temperatures}

Pretransient and transient temperature data summaries are presented in Appendix A, Part 1.2, for four major test assembly components: the shroud, guard fuel rods, test fuel rods, and instrument lead carriers. The temperatures of the coolant in the subchannels are also presented. During early operations and transient operation, several sensors failed, so the data from these sensors are subsequently deleted from the data graphs.

The test assembly coolant temperature profile across the diagonal at Level 16 is shown in Figure A.1.2.1.1 for MT-1 pretransient operation, which is also typical of the transient test; it is a combination of subchannel and carrier TC data. A set of axial temperature profiles for the shroud channels during pretransient operation is provided in Figure A.1.2.1.2, showing typical channel wall temperatures for each corner of the shroud. A set of elapsed time temperature profiles is provided (Figure A.1.2.1.3) that shows the axial temperature gradients and peak temperatures of the shroud at 10 time intervals between the time when reflooding was started and when the shroud was quenched. TC data at the test assembly inlet (Level 1), the test assembly outlet (Level 20), and the hanger tube (Level 21) provide temperature data continuity over the entire test train. 
Guard fuel rod temperatures recorded during the transient test are presented in Figure A.1.2.2 as averaged values at each of the sensor levels $(13,15$, and 17). These data are from TCs located on the cladding interior. Typical temperature differences between these guard fuel rods can be seen in the preconditioning data sumary (Figure A.1.1.2.2).

Figure A.1.2.3 contains temperature histories for the test fuel rods at the same sensor levels $(13,15$, and 17) used for guard fuel rods in Figure A.1.2.2. These data are from interior TCs with the addition of a central TC at Level 17 for comparison. The data collected for all other fuel rod TCS on Levels 13, 15, and 17 are provided in Figures A.1.2.4.1 through A.1.2.4.10. Obviously, some of them failed during the MT-1 transient test, but some early data are probably valid. They are noted as failed, both here and in Section 3.6 below.

\subsection{TEST COOLANT TEMPERATURES}

A special section of coolant temperature data is not provided graphically in Appendix A. Rather, this information is included in the following subsections that present temperature data for the test assembly shroud and test train.

\subsubsection{Preconditioning Outlet Temperatures}

During water-cooled preconditioning operation, the test assembly outlet region, hanger tube, and outlet piping operated at less than $547 \mathrm{~K}\left(525^{\circ} \mathrm{F}\right)$ as shown in Figure A.1.1.1.3.

\subsubsection{Pretransient and Transient Outlet Temperatures}

The axial temperature profile of the shroud during pretransient operation is shown in Figure A.1.2.1.2; the outlet region temperatures did not exceed $589 \mathrm{~K}\left(600^{\circ} \mathrm{F}\right)$. During the transient, the test train axial temperature profiles (see Figure A.1.2.1.3) show that the maximum temperatures of the test assembly outlet region (Level 20 ) and hanger tube (Level 21) were about 644K $\left(700^{\circ} \mathrm{F}\right)$. 


\subsubsection{Steam Probe Temperatures}

Steam probes, or bare thermocouples projecting into the coolant channel, were located at 5 levels in the test assembly. Figure A.3.1.1 shows the axial temperature profile measured during preconditioning water-cooled operation. The steam-cooled pretransient temperature profile is shown in Figure A.3.2.1. The outlet region temperatures are also shown for comparison.

\subsection{POWER COUPLING}

The NRU reactor power was recorded by the NRU reactor REDACE computer as a percentage of full reactor power and as megawatts. The reactor powers presented here are based on the percentage of full-power values.

\subsubsection{Test Assembly Preconditioning}

The test assembly power during preconditioning was determined by calorimetric methods at several power levels during the first of the 3 rises to full reactor power. Data used were the flow rates provided by the loop instrumentation, and inlet and outlet temperatures obtained by averaging 2 of the 3 test assembly inlet region (Level 1) temperatures and 3 outlet region (Level 20) temperatures. Using the test assembly temperatures rather than the loop temperatures eliminated the effect of heat losses in the loop piping. The power coupling calculated in this manner is shown in Table 3.2.

\section{TABLE 3.2. Power Coupling}

\begin{tabular}{ccc} 
Reactor Power, \% & Test Assembly Power, $\mathrm{kW}$ & \multicolumn{1}{c}{ Coupling (a) } \\
\cline { 1 - 2 } 20.0 & 11.4 & -- \\
20.0 & 448.0 & 22.4 \\
50.0 & 1059.0 & 21.2 \\
100.0 & 2465.0 & 24.6 \\
& & Average $=22.7$
\end{tabular}

(a) Coupling is defined as Test Assembly Power divided by percent of full reactor power. 
The non-zero value of calculated test assembly power at zero reactor power is a measure of the accuracy of the inlet and outlet temperature difference. It is small, and it is also due to residual (shutdown) gamma heating.

The average coupling of 22.7 is slightly larger than 21.1 determined during preconditioning for the prototypic thermal-hydraulic (PTH) test series and probably represents a slight difference in the reactor loading between the two tests.

\subsubsection{Test Assembly Pretransient}

The test assembly power was also determined during the steady-state pretransient operation in the same manner as for preconditioning operation. The test assembly power obtained was $141.1 \mathrm{~kW}$. The reactor power was $5.8 \%$, which gives a coupling value of 24.3 . This value is also slightly higher than 22.8 found during the PTH test series.

\subsection{LIQUID LEVEL MEASUREMENT}

The liquid level during the transient was measured with a liquid displacement device positioned inside an open-ended cladding tube at rod location 4D (See Figure 1.1). This device replaced the thermocouples and SPNDs positioned in the instrument tube $4 D$ during the PTH test series.

The upper end of the liquid displacement float was connected to the core a of a linear variable differential transformer (LVDT) to measure the axial movement of the float. The liquid level detector (LLD) was designed so that a 12-ft change in fluid elevation inside the tube would produce a 1-in. change in movement of the float and LVDT core. The response of the LLD during the transient is shown in Figure 3.2.

The LLD responded in a questionable manner to reflood coolant injection; its short-term reaction is not fully explained. It responds to changes in liquid level, changes in fluid density, and hydrodynamic pressure of the reflood coolant flow. Perhaps its initial (60 to $80 \mathrm{~s}$ ) response was due to the hydraulic effects of reflood water and steam generation on the hot test assembly surfaces. After saturated steam flow was established ( $>120 \mathrm{~s})$, the LLD response was more realistic. 


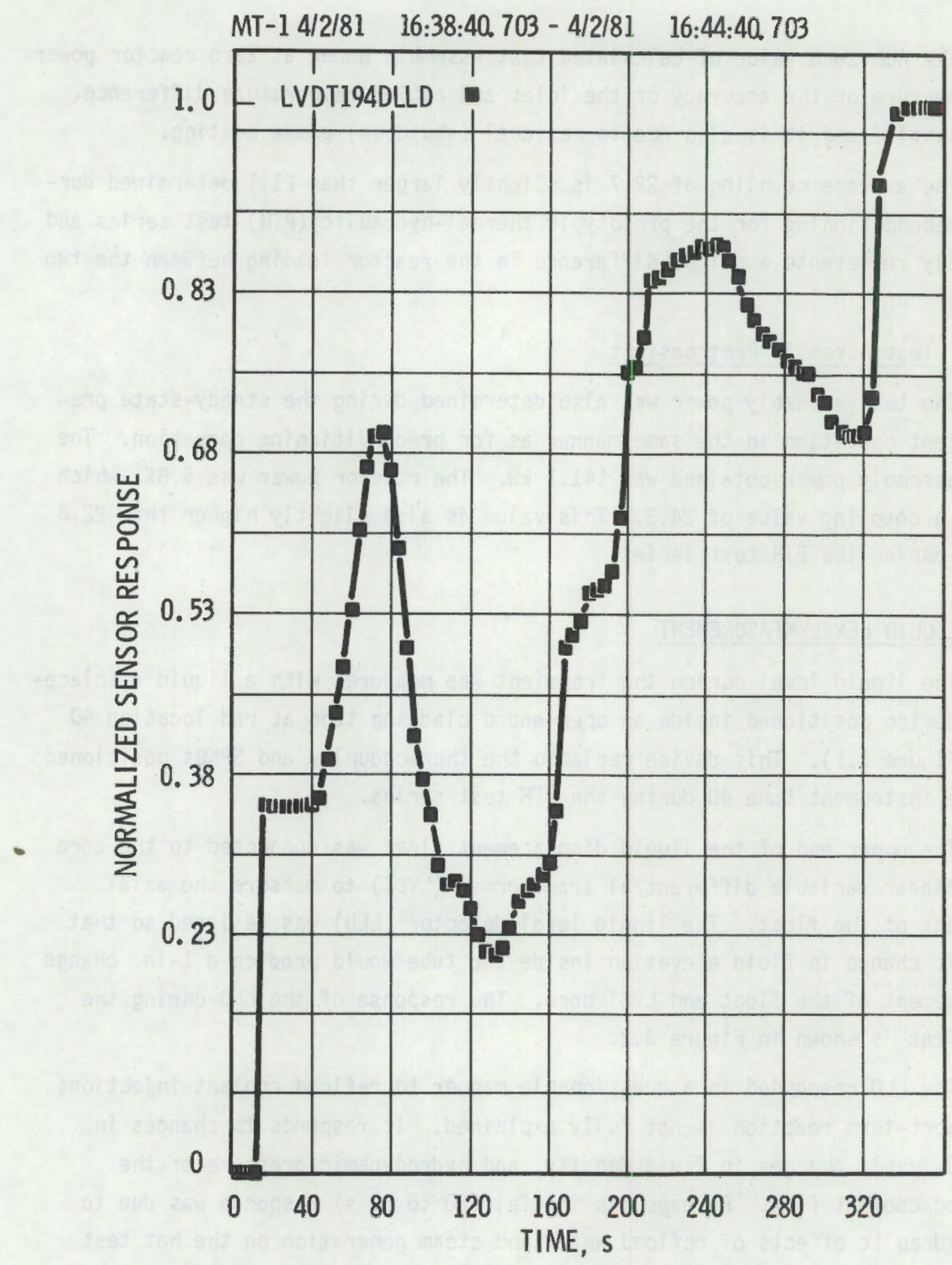

FIGURE 3.2. Change in Fluid Level During the Transient 


\subsection{NEUTRON FLUX DISTRIBUTIONS}

The neutron flux is measured by SPNDs mounted on the test assembly shroud at several locations, and by NRU flux detectors in neighboring reactor cell locations. Typical MT-1 locations are shown in Figure 3.1. MT-1 neutron flux data are provided in Section A.2 for comparison among preconditioning (watercooled), pretransient, and transient (steam-cooled) operations. NRU REDACE data are provided in Figure 3.3 to illustrate the comparable axial flux profiles inside the MT-1 test train (averaged) and in nearby locations of the NRU reactor.

\subsubsection{Preconditioning Neutron Flux}

The axial neutron flux distributions at full reactor power operation are shown in Figure A.2.1.1. When the SPND showing the greatest variance from the other sensors is discarded (SPND-16-1F-S-C), the resultant preconditioning axial flux profile (Figure A.2.1.1) conforms with the neutronic test design distribution (Heaberlin et al. 1979) and that measured in the PTH experiments (Mohr et al. 1981). The peak-to-average power profile calculated (Heaberlin et al. 1979) for the NRU experiments had an axial peak-to-average ratio of 1.56. The MT-1 neutron flux data, averaged at each shroud instrument level, were used to construct an axial flux profile in Figure 3.3. It has a peak-toaverage ratio of 1.57 . The diagonal flux profile across the MT-1 test assembly at full reactor power is shown in Figure A.2.1.2.

Neutron flux is measured both inside the MT-1 shroud and in flux detector rods (FDR) of the NRU reactor. The FDR core position closest to the test lattice position is $M-23$ (see Figure 2.1). The flux measured at position P-18 was also chosen for comparison because vanadium detectors in it had been corrected for burnup and calibrated for neutron flux. Other platinum detectors in both $M-23$ and $P-18$ provided a relative axial neutron flux profile (see Figure 3.3 ) near the L-24 position (where MT-1 was located). In the NRU, the true flux is more peaked than evident from these flux profiles, due to the $f$ act that flux detector burnout (degradation) occurs more rapidly in higher flux regions. These neutron flux profiles are compared in Figure 3.3 with 


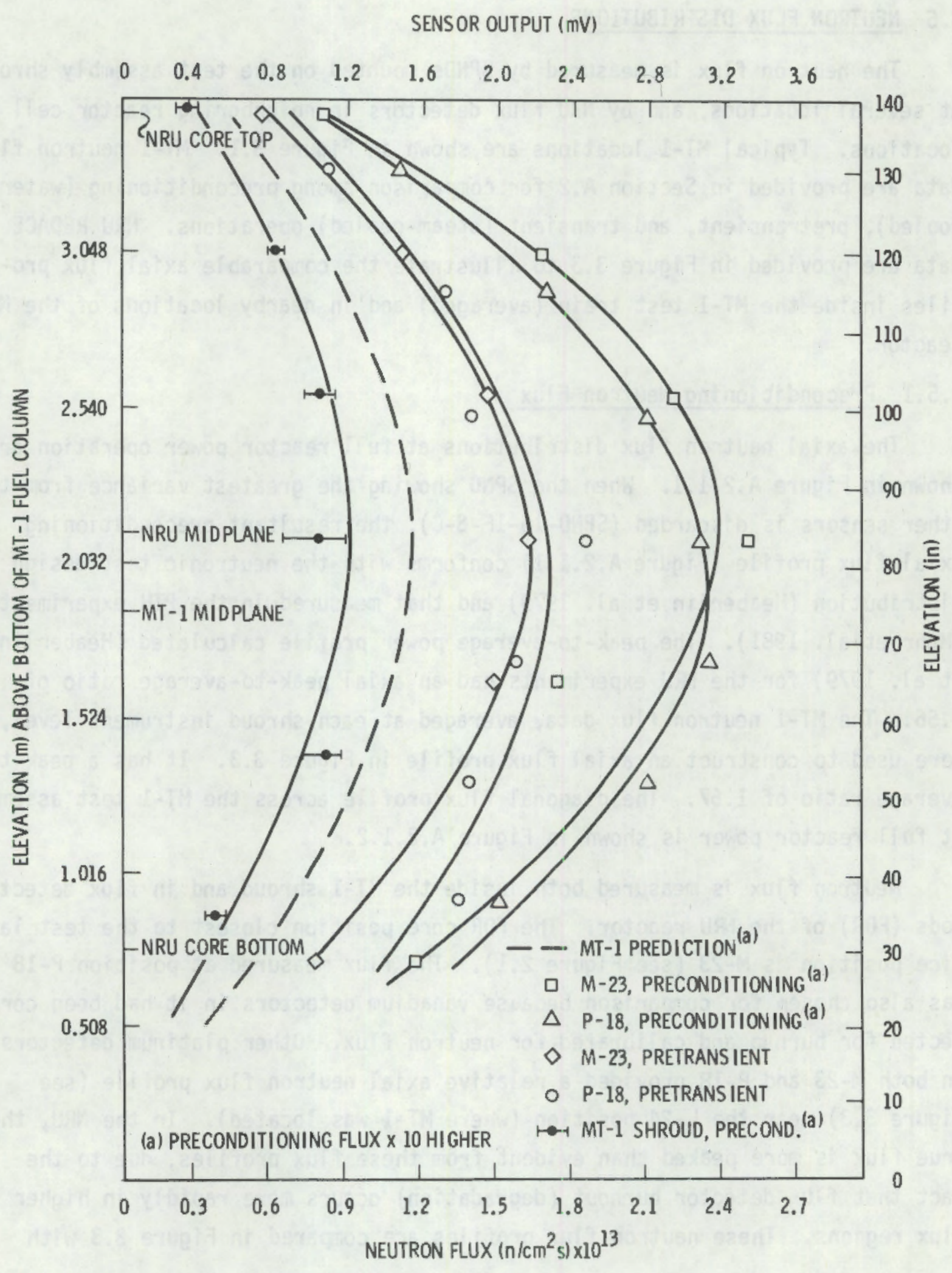

FIGURE 3.3. Neutron Flux In and Outside the MT-1 Test Assembly 
average neutron flux measured inside the MT-1 shroud. Midplane nonsymetry is due to the fact that the NRU reactor midplane is about $0.30 \mathrm{~m}$ (12 in.) above the midplane of the MT-1 fuel column. An axial flux skew results.

\subsubsection{Pretransient and Transient Neutron Flux}

NUU reactor operation at nominally $6 \%$ of full power provided the steadystate heat source for both the pretransient and transient operation. The neutron fluxes during pretransient and transient operation are summarized in Appendix A, Part 2.2. For a comparison between water- and steam-cooled neutron flux distributions, the diagonal neutron flux profiles across the test assembly are shown in Figure A.2.1.2 for preconditioning operation, and in Figure A.2.2.1 for pretransient operation, respectively.

The preconditioning axial neutron flux profile is provided in Figure A.2.1.1 for each corner of the shroud for comparison with the pretransient data provided in Figure A.2.2.2.

Subtle changes in the neutron flux were caused by the neutron absorption of the reflood water. To evaluate the changing density of the coolant, the changing neutron flux in selected shroud channels at various levels is presented in Figure A.2.2.3 for the transient operation. The plotted differential flux is the difference between the neutron flux at any time during the test and the average flux calculated for $10 \mathrm{~s}$ before reflooding began. The data presented probably include the effects of the NRU reactor control system response to the reflood water neutron absorption and the temperature sensitivity of SPND instrument leads.

\subsection{INSTRLMENT FAILURE}

Despite conservative design practices and careful fabrication, shipping, and assembly procedures, some instrumentation did not pass the installation and final checkout inspections and others failed during the experiment. The following describes problems, anomalies, and the final repairs or condition of the instrumentation at the beginning of the MT-1 experiment. A final tally of failed instrumentation at the end of the experiment is also provided. 


\subsubsection{Final Test Assembly Pretest Instrument Conditions}

- Steam probe. Steam probe brackets, that were spot-welded to the spacer grid at location 5B and Level 12, broke away. However, because the bracket is notched into the grid (captured), the steam probe was fust wired to fuel rod 5B (0.020 in. SS lockwire), to prevent flow-induced vibration.

- Thermocouples. All TCs we checked for operability, location, and lead connections with the reference drawing(a). Five failed TCS were identified: TC-10-1A-S-C, TC-13-3B-IR-2, TC-15-1F-S-C, TC-16-5E-SP-4, TC-17-2D-IR-2. The probable cause of failure was shipping/hand ling.

- High pressure connectors. Three high pressure connectors (\#3, \#4, and \#5) were installed on the MT-1 hangar tube. Connector \#4 was installed as designed ${ }^{(b)}$. The 3 torque-seals in connectors \#3 and $\# 5$ were eliminated and were brazed ${ }^{(c)}$. A 11 of the sensors $(d)$ are suspected to have failed due to improper sealing (see Table 3.3).

- Deleted thermocouples. Sensor TC-17-2D-IR-2 (e) was deleted from the instrument array due to the substitution of a duplicate of fue 1 rod $4 B$ for the faulty fuel rod $2 D$. Thermocouples associated with $\operatorname{rod} 4 D^{(f)}$, were also deleted from the test assembly (TC-3-4D-SP-4, $T C-6-4 D-5 P-4, T C-12-4 D-S P-4$, and TC-18-4D-SP-4) because rod 4D was replaced by the liquid level detector.

- General notes on final assembly.

(a) Stainless stee 1 lockwire (.040 in. dia.) was used (4 places) to restrain all leads associated with the test fuel rod bundle (including the liquid level detector at position 4D).

(a) Drawing H3-41804, sheets 1 (rev 5), 2 (rev 4), and 3 (rev 1 ).

(b) Drawing H3-41778, sheets 1 through 4 (all rev 0 ).

(c) Brazed seal.

(d) Drawing H3-41803, sheet 6 (rev 0).

(e) Drawing H3-41804, sheet 2 (rev 4).

(f) Drawing H3-41804, sheet 1 (rev 5) and sheet 3 (rev 1). 
TABLE 3.3. High Pressure Connector Instrumentation(a)

\begin{tabular}{lll}
\multicolumn{2}{c}{ Sensors } & \multicolumn{1}{c}{ Connector } \\
TC-13-3B-IR-2 & TC-18-2C-IR-2 & \\
TC-15-3B-IR-4 & TC-18-3E-0R-4 & High pressure connector \#3 \\
TC-18-3E-IR-1 & TC-18-2C-OR-1 & \\
TC-17-3D-IR-5 & TC-17-3D-IR-C & \\
TC-17-3D-IR-3 & TC-17-2D-0R-1 & High pressure connector \#4 \\
TC-17-3D-IR-4 & PS-19-3E-C & \\
& & \\
TC-15-2C-IR-1 & TC-15-3C-IR-7 & High pressure connector \#5 \\
TC-15-3C-IR-2 & TC-15-3C-IR-C &
\end{tabular}

(a) Drawing H3-41778, sheets 1 through 4 (a11 rev 0 ).

(b) A11 TC leads associated with the head seal "C", (a) but not part of the cruciform test fuel rod bundle, were separately bund led up to a level about $5 \mathrm{ft}$ below the feed-through plug.

(c) Guard fuel rod bundle leads and shroud leads were attached to the hanger tube over the full length, but the rest of the leads that must be fanned out at this hinge, are lockwired to the hanger tube, beginning about $4 \mathrm{ft}$ above the shroud.

\subsubsection{Instrument Failures}

A total of 41 instruments probably failed sometime during various operations before and during the MT-1 experiment. However, some "recovered" during MT-1 operation and at least 100 remained operational throughout the experiment.

- Five TCs failed during shipment and final assembly (see Section 3.6.1 for listing). 
- Nineteen sensors failed during the high pressure seal leak test-all instrument leads using the $3 \mathrm{high}$ pressure connectors (see Table 3.3 for listing) plus the following: TC-8-6F-S-C, TC-18-4E-OR-4, and SPND-17-1F-S4.

- Two TCs failed during preconditioning: TC-2-6F-S-C and TC-6-6A-S-C.

- Two TCs failed during reflood tests 1 and 2: TC-13-1F-S-C and TC-6-1A-S-C.

- The final tally of failed or "suspicious" instrumentation is given in Table 3.4.

\subsection{REFLOOD FLOW MEASUREMENTS}

Prior to the pretransient test phase, 2 reflood flow tests were performed at $0.010 \mathrm{~m} / \mathrm{s}(0.4 \mathrm{in.} / \mathrm{s})$ and $0.051 \mathrm{~m} / \mathrm{s}(2.0 \mathrm{in.} / \mathrm{s})$ to calibrate the reflood loop and monitor shroud leakage. See Figures A.4.1.1.1 and A.4.1.1.2 for the turbine meter flow rate recordings.

After the MT-1 transient test was completed: 3 more reflood tests were performed. They were run at $0.051 \mathrm{~m} / \mathrm{s}(2.0 \mathrm{in.} / \mathrm{si}), 0.098 \mathrm{~m} / \mathrm{s}(3.7 \mathrm{in.} / \mathrm{s})$, and $0.013 \mathrm{~m} / \mathrm{s}(0.5 \mathrm{in.} / \mathrm{s})$. The turbine meter flow rates are shown in Figures A.4.1.1.3 through Á.4.1.1.5.

The reflood flow system included series-connected Barton and FisherPorter turbine flow meters in a high flow rate line, and series-connected Barton and Fisher-Porter turbine flow meters in a paralle 1 low flow rate line. In addition, a parallel standby reflood line provided emergency reflood coolant if needed; none was required during the MT-1 experiment.

At the start of the reflood flow test, a fast reflood rate was used to bring the reflood coolant level up to the bottom of the fuel rods. The demand control valve in the high flow rate reflood line is preset fully open for $2 \mathrm{sec}$. After $2 \mathrm{sec}$, solenoid valves switch flow through the low flow line where the flow control valve was preset $[\mathrm{e.g.,} 0.051 \mathrm{~m} / \mathrm{s}(2.0 \mathrm{in.} / \mathrm{s})]$. 
TABLE 3.4. Failed Instrument Final Tally

$\begin{array}{ll}\text { TC-2 -6F-S-C } & \text { TC-18-1F-S-C } \\ \text { TC-6-1A-S-C } & \text { TC-18-2C-IR-2 } \\ \text { TC-6-6A-S-C } & \text { TC-18-2C-OR-1 } \\ \text { TC-7-4F-0R-1 } & \text { TC-18-3E-IR-1 } \\ \text { TC-8-5B-OR-1 } & \text { TC-18-3E-OR-4 } \\ \text { TC-8-6F-S-C } & \\ \text { TC-10-1A-S-C } & \text { SPND-6-IF-S4 } \\ \text { TC-10-1A-S-C } & \text { SPND-12-IF-C } \\ \text { TC-13-1F-S-C } & \text { SPND-13-6A-S2 } \\ \text { TC-13-3B-IR-2 } & \text { SPND-13-1A-S1 } \\ \text { TC-13-3C-IR-C } & \text { SPND-15-1A-S1 } \\ \text { TC-15-2C-IR-1 } & \text { SPND-16-1F-C } \\ \text { TC-15-3B-IR-4 } & \text { SPND-17-6A-S2 } \\ \text { TC-15-3C-IR-7 } & \text { SPND-17-1F-S4 } \\ \text { TC-15-3C-IR-1 } & \\ \text { TC-15-3C-IR-2 } & \text { PS-19-4C-C1 } \\ \text { TC-15-1F-S-C } & \text { PS-19-4C-C } \\ \text { TC-16-5E-SP-4 } & \text { PS-19-5D-C1 } \\ \text { TC-17-2D-IR-2 } & \text { PS-19-5D-C } \\ \text { TC-17-2D-OR-1 } & \\ \text { TC-17-3D-IR-3 } & \text { PTS-19-4C-C } \\ \text { TC-17-3D-IR-4 } & \\ \text { TC-17-3D-IR-5 } & \\ \text { TC-17-3D-IR-C } & \\ \text { TC-17-5D-OR-3 } & \end{array}$

Steam probe temperature histories were used to provide an independent measurement of the reflood coolant level (and reflood flow rate) in the test assembly. Figures A.4.2.1.1 and A.4.2.1.2 provide the data for pretest reflood rate calibration (measuring the time required between subsequent level quenches) and Figures A.4.2.2.1 through A.4.2.2.3 provide the data for posttest reflood rate calibrations. 
Similar information is presented in Section 5 of Appendix $A$ for the MT-1 transient. Figures A.5.1.1 and A.5.1.2 show the test assembly transient reflooding rate as measured by the turbine flow meters and Figure A.5.2.1 shows the average temperature history of steam probes at various levels in the test assembly to independently calibrate the reflood flow rate. The reflooding inlet coolant temperature history is shown on Figure A.5.2.2.

\subsection{FUEL ROD PRESSURE}

Changes in the gas pressure in the plenums of the test rods were determined using pressure switches attached to the upper end of nine of the test fue 1 rods and pressure transducers attached to two of the test fuel rods ( $3 C$ and $5 C$ ). See Figures A.6.1.1 and A.6.1.2. Eleven test fuel rods were pressurized with helium to $3.21 \mathrm{MPa}(465 \mathrm{psia})$ at room temperature. These test fuel rods are located in the bundle as shown in Figure 3.1.

\subsubsection{Pressure Switches}

The pressure switch was an electrical device that indicates a change in output when the pressure in the fuel rod plenum drops below a cutoff pressure leve1. However, it does not necessarily indicate the time of fuel rod rupture unless good pneumatic cormunication between the rupture site and the fuel rod plenum is maintained. The switch consisted of a bare thermocouple junction that was grounded when the plenum pressure exceeded the cutoff pressure level and switched to an ungrounded mode (open position) when the pressure dropped below the cutoff level. The temperature of the bare thermocouple junction, as 11 as the electrical output of the grounded circuit, are plotted in Figures A.6.2.1, A.6.2.2, and A.6.2.3. The upper grow of curves on each figure shows the temperature of the bare thermocouple junction as a function of time. The lower group of curves represents the output of the thermocouple junction to a grounded circuit and is plotted as relative output. The latter curves show a stable output as long as the plenum pressure is above the cutoff pressure wich, for the operating temperature of the MT-1 test, is about $-2.07 \mathrm{MPa}$ (300 psia). When the pressure drops below the cutoff pressure, the grounded circuit TC response either disappears or its behavior radically changes. 
If rupture of the cladding occurs, the change in output of the switch does not necessarily indicate the time of fue 1 rod rupture. The helium communication delay due to the tortuous path through the pellet stack between the location of the fuel rod rupture site and the fuel rod plenum must be considered.

Pressure switches on six fuel rods--3B, 4B, 2C, 2D, 3E, and 4E--indicated that plenum pressures dropped below the cutoff pressure of $\sim 2.07 \mathrm{MPa}$ (300 psia) between 60 and $90 \mathrm{~s}$ into the transient. The pressure switches on rods $4 \mathrm{C}$ and 3D indicated (Figure A.6.2.1) that their plenum pressure did not drop below $2.07 \mathrm{MPa}(300 \mathrm{psia})$ during the transient $(360 \mathrm{~s})$. The output from the rod $5 \mathrm{D}$ pressure switch circuit was out of range (failed) during the transient; however, the output from its thermocouple circuit was recorded (Figure A.6.2.2) even though it does not indicate when depressurization occurred.

\subsubsection{Pressure Transducers}

Two test fuel rods (positions $3 C$ and $5 C$ ) were each fitted with a pressure transducer to measure the changing fuel rod plenum pressure during the transient. One transducer operated on the eddy current principle (identified on Figure 3.1 as PTK) and the other utilized a linear variable differential transformer (LVDT) (identified on Figure 3.1 as PTS).

Figure A.6.1.1 is a plot of the PTS transducer output from the test fuel rod in the $5 \mathrm{C}$ location. It shows a modest increase in plenum pressure and subsequently, a decrease just prior to $65 \mathrm{~s}$ into the transient. This is followed by a rapid increase and slower decrease in pressure, reaching a peak pressure at about $100 \mathrm{~s}$ into the transient. The thermal sensitivity of this LVDT necessitated a pressure correction after $70 \mathrm{~s}$ because the temperature at the location of the transducer decreased. Figure A.6.1.2 shows that the corrected peak plenum pressure was $9.66 \mathrm{MPa}(1400 \mathrm{psia})$. After reaching the peak fuel plenum pressure, it gradually decreased to a corrected value of $3.10 \mathrm{MPa}$ (450 psia) at $360 \mathrm{~s}$.

The plot of the PTK eddy current tranducer (Figure A.6.1.1) shows a constant pressure from 0 to $60 \mathrm{~s}$ into the transient. A printout of the data during this period indicates that possibly the PTK transducer was stuck. 
Subsequently, the plenum pressure dropped rapidly to a minimum of $4.24 \mathrm{MPa}$ (615 psia) at $90 \mathrm{~s}$, then rapidly increased to $6.34 \mathrm{MPa}(920 \mathrm{psia}$ ) at $100 \mathrm{~s}$, and then decreased to $2.62 \mathrm{MPa}$ ( $380 \mathrm{psia}$ ) at $360 \mathrm{~s}$. Because the thermal sensitivity of the eddy current transducer was minimal, its pressure history data did not require a temperature correction. However, these results are not particularly meaningfut.

\subsubsection{Summary of Pressure Switch and Pressure Transducer Data}

The pressure switch and pressure transducer data are surmarized in Table 3.5 .

Three inner test rods (3C, 4C and 3D) remained above $2.07 \mathrm{MPa}$ (300 psia) a long with one corner test fuel rod (5C). A comparison of the times of pressure switch opening with the configuration of thermocouples in the fuel rods suggests a possible correlation between the thermocouple configuration and gas cormunication between the rupture location and fuel rod plenum. 
TABLE 3.5. Summary of Pressure Switch and Pressure Transducer Data

\begin{tabular}{|c|c|c|}
\hline Fuel Rod & Rupture Time (a) & Type of Instrument \\
\hline $3 B$ & 60 & $\mathrm{PS}^{(\mathrm{b})}$ \\
\hline $4 B$ & 80 & PS \\
\hline $2 \mathrm{C}$ & 95 & PS \\
\hline $3 C$ & (e) & $\operatorname{PTS}^{(c)}$ \\
\hline $4 C$ & (e) & PS \\
\hline $5 C$ & (e) & PTK $(d)$ \\
\hline $2 D$ & 75 & PS \\
\hline $3 D$ & (e) & PS \\
\hline 50 & failed & PS \\
\hline $3 E$ & 85 & PS \\
\hline $4 \mathrm{E}$ & 75 & PS \\
\hline
\end{tabular}

\footnotetext{
(a) Time into transient when plenum pressure dropped below $\sim 2.07 \mathrm{MPa}$ (300 psia)

(b) PS = Pressure switch

(c) PTS = Pressure transducer, LVDT bellows type

(d) PTK = Pressure transducer, eddy current type

(e) Remained above $2.07 \mathrm{MPa}$
} 


\subsection{ANALYSIS AND COMPARISON OF TEST DATA}

The test data were given a preliminary analys is to confirm that the test conditions were close to those of PTH-110. The results of this preliminary analys is are presented in this section. The imposed test conditions very closely dup licated PTH-110 test conditions.

Although it would be ideal to compare temperatures measured by TCs on fuel rods at the same locations in both PTH-110 and MT-1, it was not possible to do so for test fuel rods in the central core region. High instrument failure rates in the severe test environment precluded this direct comparison of data.

\subsection{COMPARISON OF THE PTH-110 TEST AND THE MT-1 TEST}

Test MT-1 was designed to match the prototypic thermal-hydraulics test PTH-110. PTH-110 was selected as a reference test because it provided temperatures in the high range, 1093 to $1143 \mathrm{~K}\left(1520\right.$ to $\left.1600^{\circ} \mathrm{F}\right)$, with a timeat-temperature long enough to cause the pressurized test fuel rods to rupture.

Tables 2.2 and 3.1 compare the predicted test conditions and test results, respectively. The differences between the peak cladding temperatures measured in tests PTH-110 and MT-1 (Figure 4.1) are due, in part, to the fact that these are temperatures measured by different positioned thermocouples in different fuel rods operating at different power. The MT-1 transient started out slightly hotter, $8 \mathrm{~K}\left(13^{\circ} \mathrm{F}\right)$, and at a higher power, about $1 \%$.

Another contributor to the temperature differences between the two tests is that the inside cladding thermocouples (e.g., TC-15-4F-IR2) for test PTH-110 were not spot-welded to the cladding as they were for test MT-1. Calculations show that this should cause the temperatures measured in the PTH-110 test to be 11 to $22 \mathrm{~K}\left(20\right.$ to $40^{\circ} \mathrm{F}$ ) higher than the corresponding temperatures measured in test MT-1.

Figure 4.1 compares the peak temperature of a PTH-110 guard fuel rod with . the peak test fuel rod cladding temperature history of the MT-1 test. The thermocouple in the MT-1 test fuel rod (TC-15-3B-IR4) failed sometime between 120 and $140 \mathrm{~s}$, so the hottest fuel rod cladding behavior out to the quench 


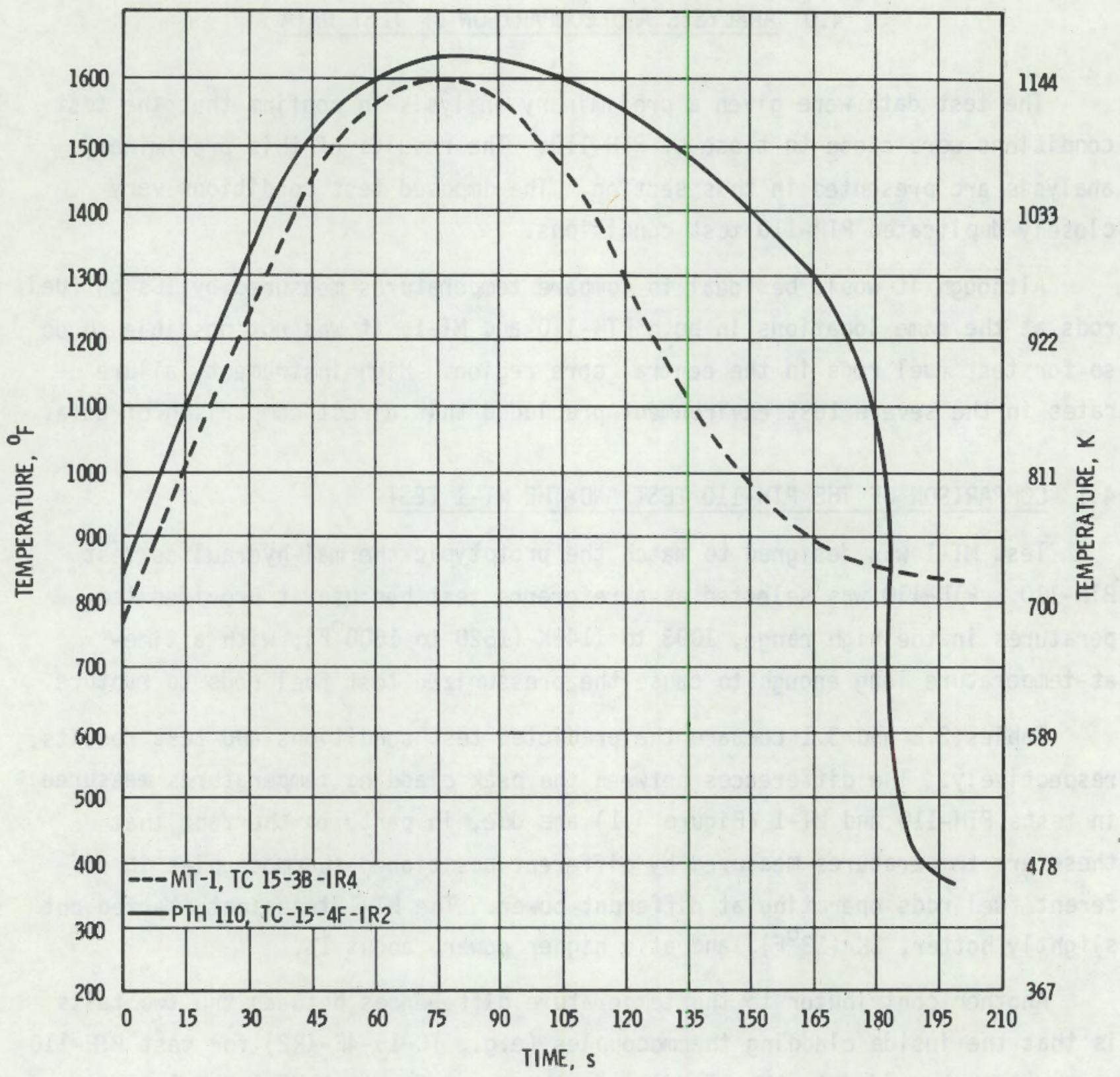

FIGURE 4.1. Comparison of Peak Fuel Rod Cladding Temperatures at Level 15 for Tests MT-1 and PTH-110

point cannot be defined. Consequently, Figure 4.2 uses the same data from test PTH-110 (TC-15-4F-IR2) for comparison with the temperature of a similar guard fuel rod (TC-15-5B-IR3) from test MT-1. They exhibit the second highest peak cladding temperatures. In Figure 4.2, the guard fuel rod temperature comparison out to the quench point is shown. 


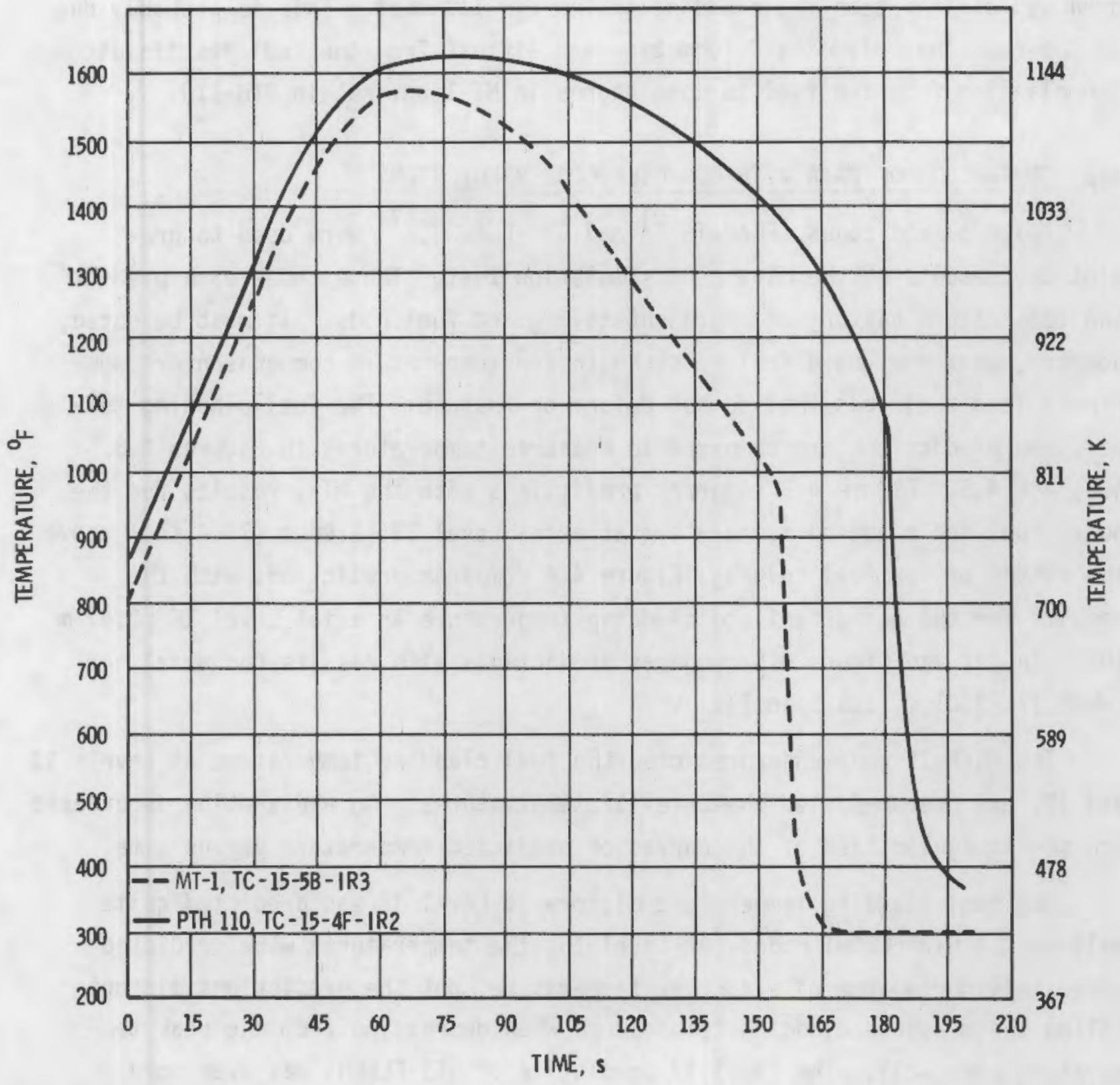

FIGURE 4.2. Comparison of Peak Guard Fuel Rod $\mathrm{Cl}$ adding Temperatures at Leve1 15 for Tests MT-1 and PTH-110

Agreement between the test results from the MT-1 and PTH-110 tests is good until the time when cladding temperature decreases. After that time, the thermocouples in the MT-1 test indicate that the cladding cools faster and 
quenches earlier than the cladding in the PTH-110 test. This is probably due to the fact that cladding deformation and liftoff from the fuel has isolated the cladding from the fuel to some degree in MT-1 but not in PTH-110.

\subsection{COMPARISON OF DATA WITH COMPUTER CODE PREDICTIONS}

Two fuel rod codes, FRAP-T5 ${ }^{(6)}$ and GT3-FLECHT, ${ }^{(7)}$ were used to predict the results of the MT-1 LOCA simulation test. These codes each predict the temperature history of representative guard fuel rods. It must be noted, however, that the guard fuel rods chosen for temperature comparison are nonpressurized fuel rods that do not deform or rupture. The fuel cladding temperature predictions are compared to measured temperatures in Figures 4.3, 4.4, and 4.5. Figure 4.3 compares predictions with the MT-1 results for the guard fuel rod cladding temperature at axial Level 13 [1.94 $\mathrm{m}$ (76.4 in.) above the bottom of the fuel column]; Figure 4.4 compares predictions with the results for the guard fuel rod cladding temperature at axial Level 15 [2.47 m (97.2 in.)]; and Figure 4.5 compares predictions with results for axial Level 17 [3.01 m (118.5 in.)].

The FRAP-T5 code underpredicted the fuel cladding temperature at Levels 13 and 15, and overpredicted the Level 17 temperatures. No explanation is offered for the irregularities of the curves of predicted temperature versus time.

The fuel cladding temperature history at Level 13 was predicted quite we 11 by the GT3-FLECHT code. At Level 15, the temperatures were predicted adequately during the rise to peak temperature, but the predictions did not follow the measured cladding temperature when decreasing from the peak temperature very well. The Level 17 prediction of GT3-FLECHT was even more conservative than the prediction at Leve1 15.

Cladding deformation predictions for test fuel rods by the two codes are fairly consistent with each other. Both codes predict very little cladding dilatation taking place until the onset of cladding instability, approximately $35 \mathrm{~s}$ after the start of the transient (or $3 \mathrm{~s}$ after reflooding begins). The FRAP-T5 code predicted the eventual cladding ballooning and failure to occur at an axial elevation of approximately $2.45 \mathrm{~m}$ (96.4 in.). The GT3-FLECHT 


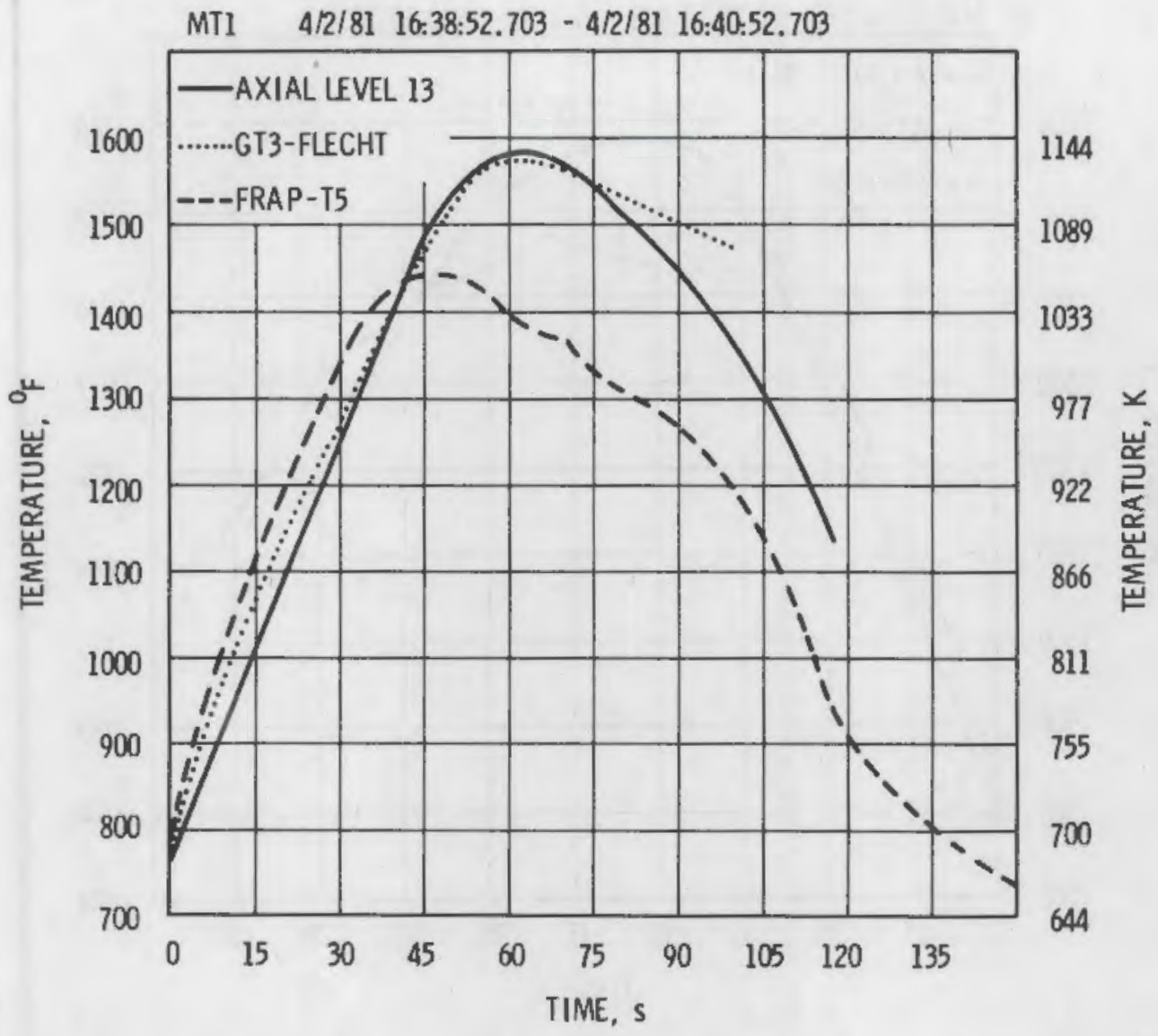

FIGURE 4.3. Comparison of Predictions and Guard Fuel Rod Cladding Temperature Measured at Level 13 (average of TC-13-4F-IR-4 and TC-13-1D-IR-2)

code predicted the failure to occur at an axial elevation of approximately $1.95 \mathrm{~m}(76.8 \mathrm{in}$.$) . The measured locations of test fuel rod ruptures were$ about $2.0 \mathrm{~m}(81 \mathrm{in.})$ above the bottom of the fuel column.

The FRAP-T5 code predicted fuel rod rupture time at approximately $45 \mathrm{~s}$ after the start of the transient. The GT3-FLECHT code predicted test fue 1 rod cladding rupture to occur about $50 \mathrm{~s}$ into the transient. Est imates of measured fuel rod ruptures range from less than $60 \mathrm{~s}$ to about $90 \mathrm{~s}$. See Section 3.8 for a discussion of the data and results.

Pretest calculations were also made using heat transfer coefficients determined from the FLECHT correlation ${ }^{(8)}$ as input to the TRUMP heat conduction code. The FLECHT correlation used in these calculations was outside 


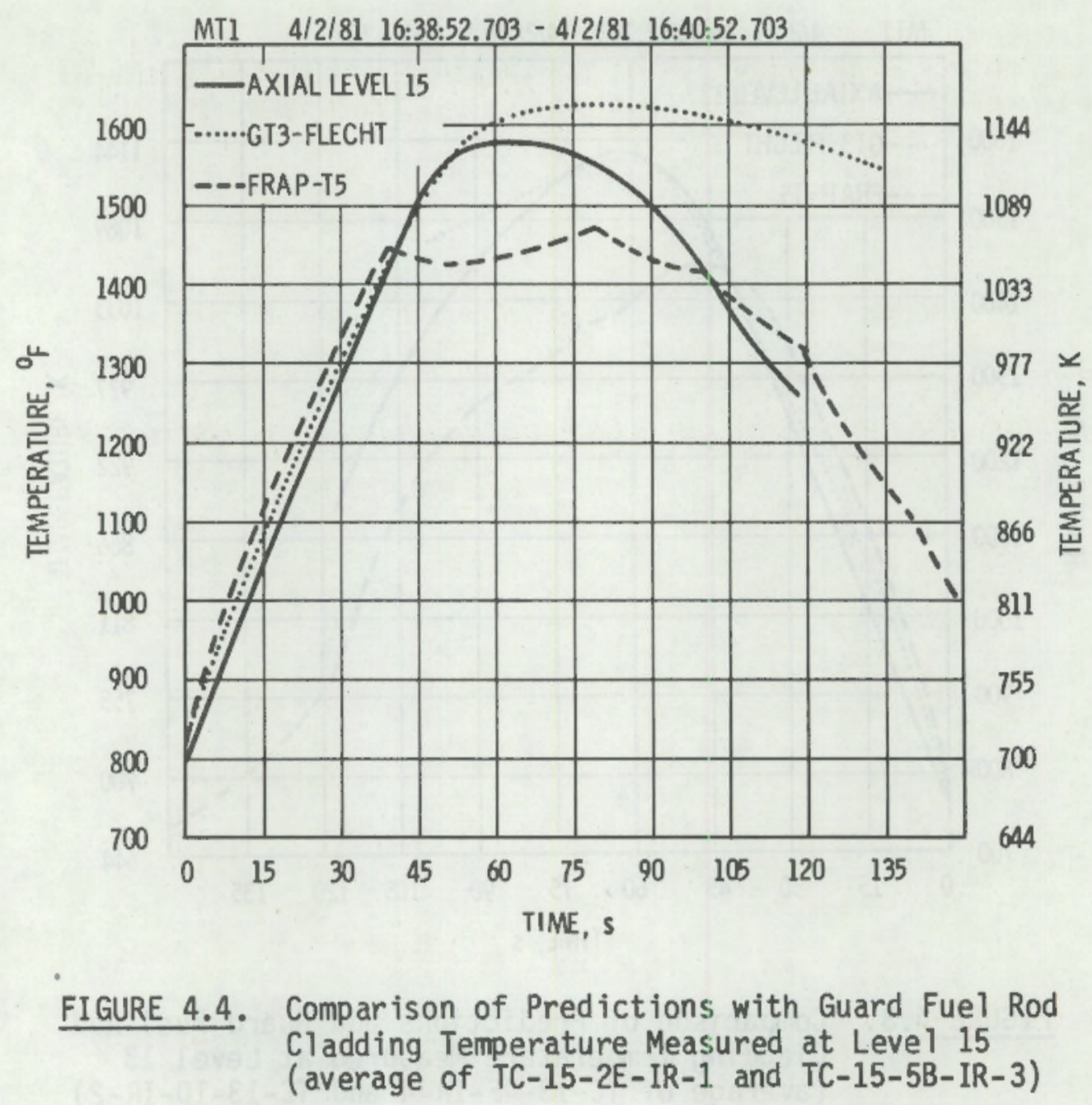

of the range of conditions for which it is valid. However, it did quite well in predicting the fuel cladding time-temperature relationship. The results are shown in Figures 4.6 and 4.7 together with measured peak cladding temperature for MT-1 guard fuel rods. Figures of this type were plotted prior to the test to provide guidance for the selection of the appropriate reflood delay and flow rate test conditions. 


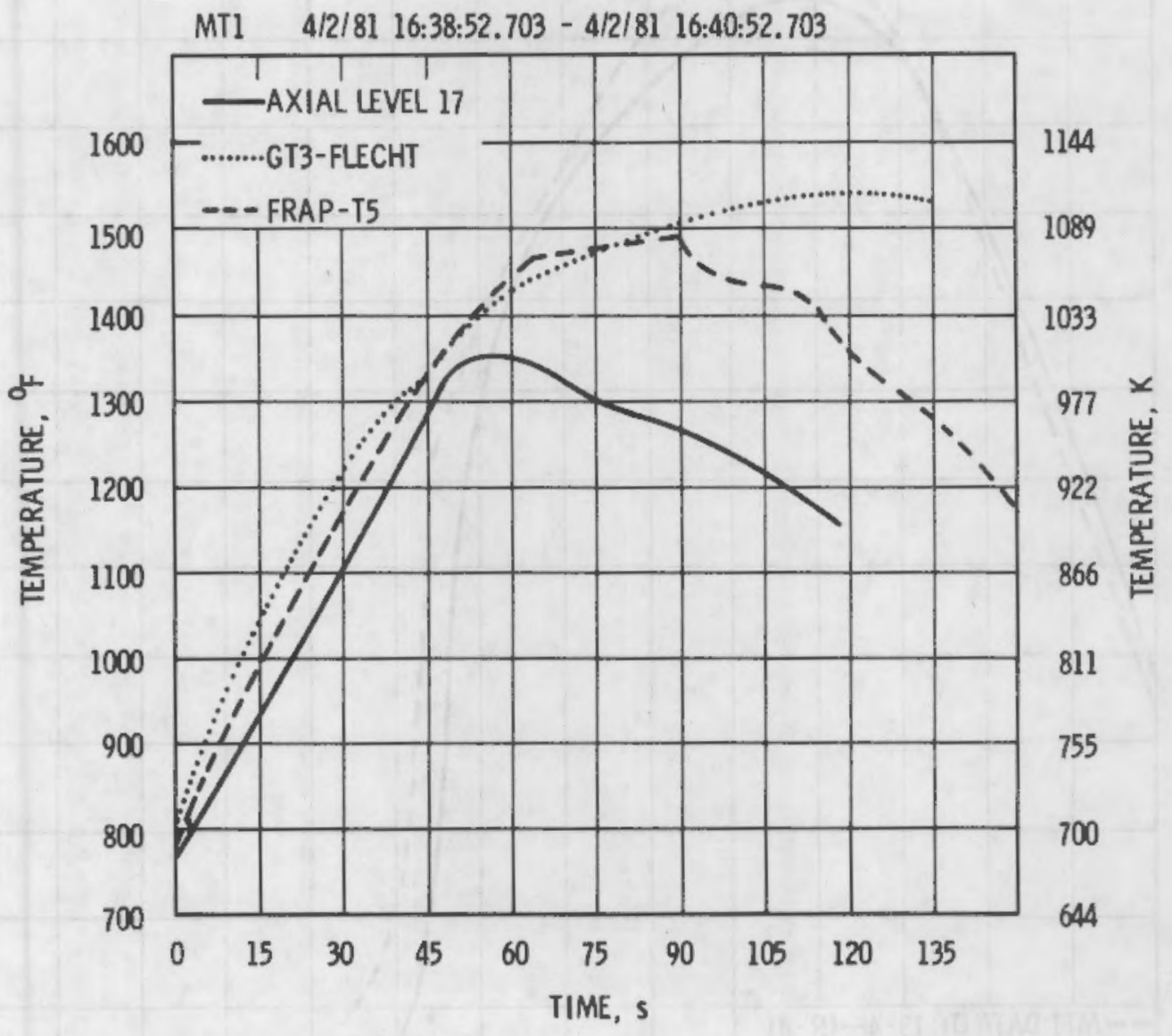

FIGURE 4.5. Comparison of Predictions with Guard Fuel Rod Cladding Temperature Measured at Level 17 (average of TC-17-2B-IR-4 and TC-17-5E-IR-2) 


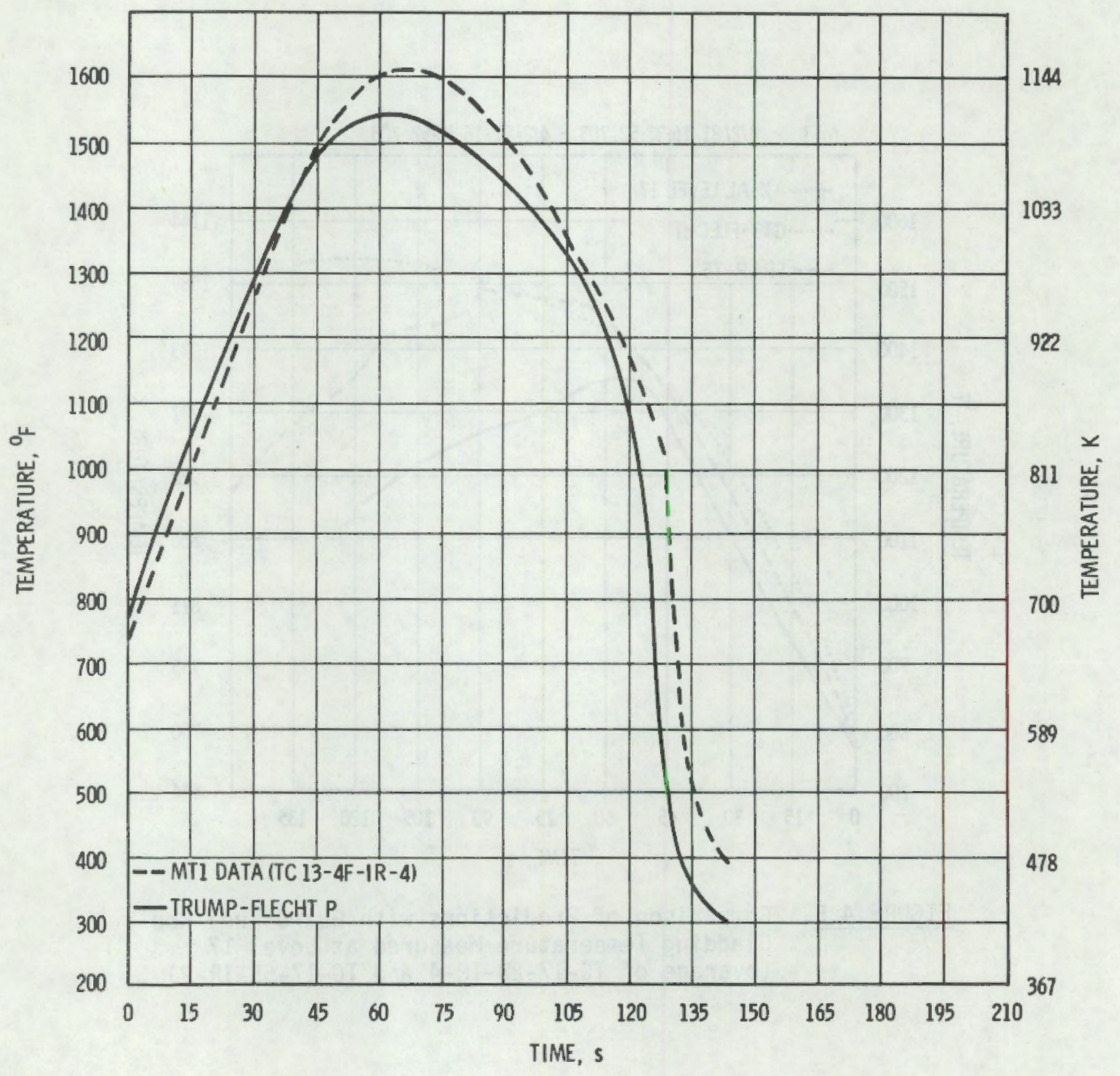

FIGURE 4.6. Comparison of TRUMP-FLECHT Predictions With MT-1 Guard Fuel Rod Cladding Temperature at Level 13 


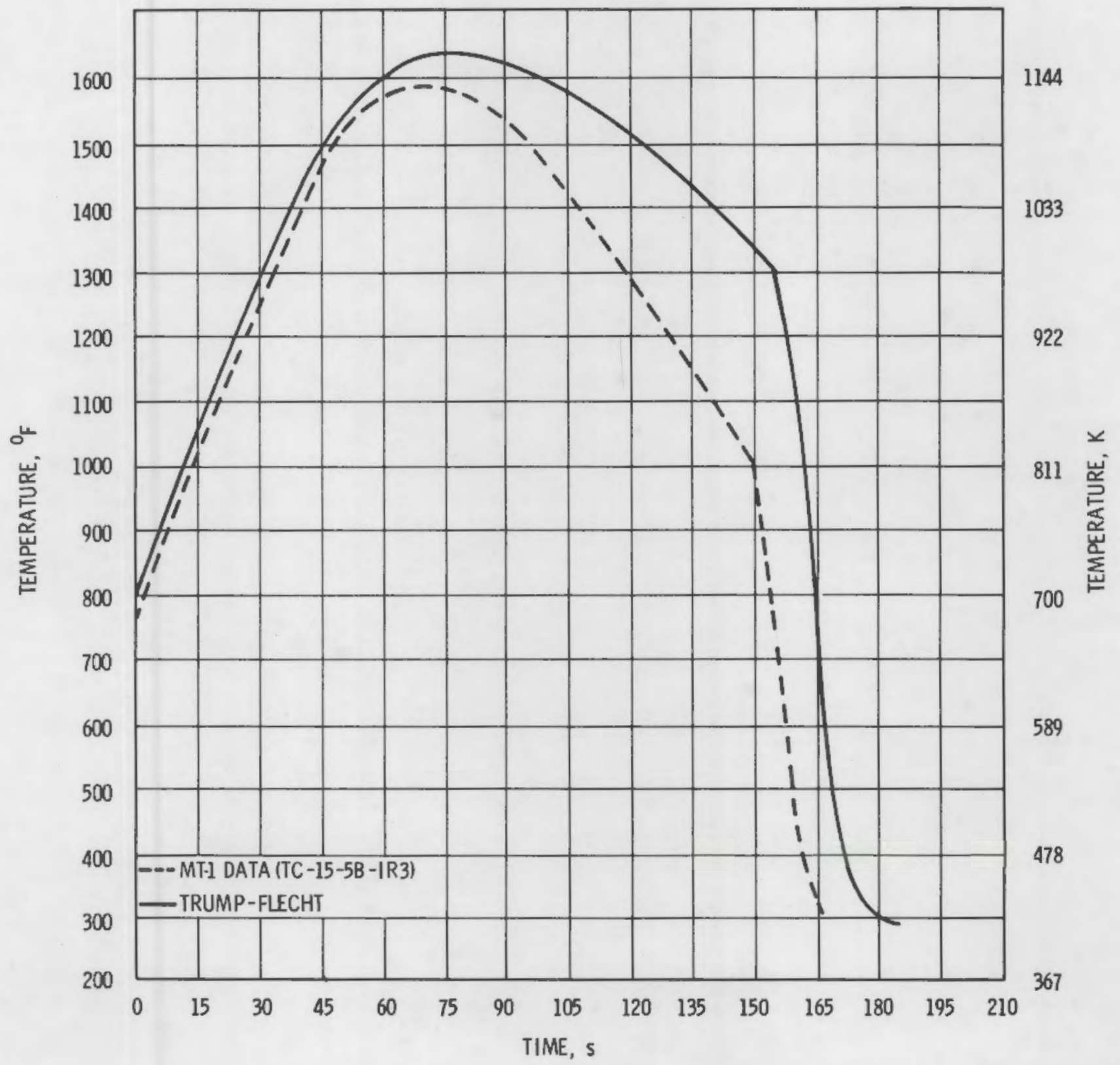

FIGURE 4.7. Comparison of TRUMP-FLECHT Predictions With MT-1 Guard Fuel Rod Cladding Temperature at Level 15 

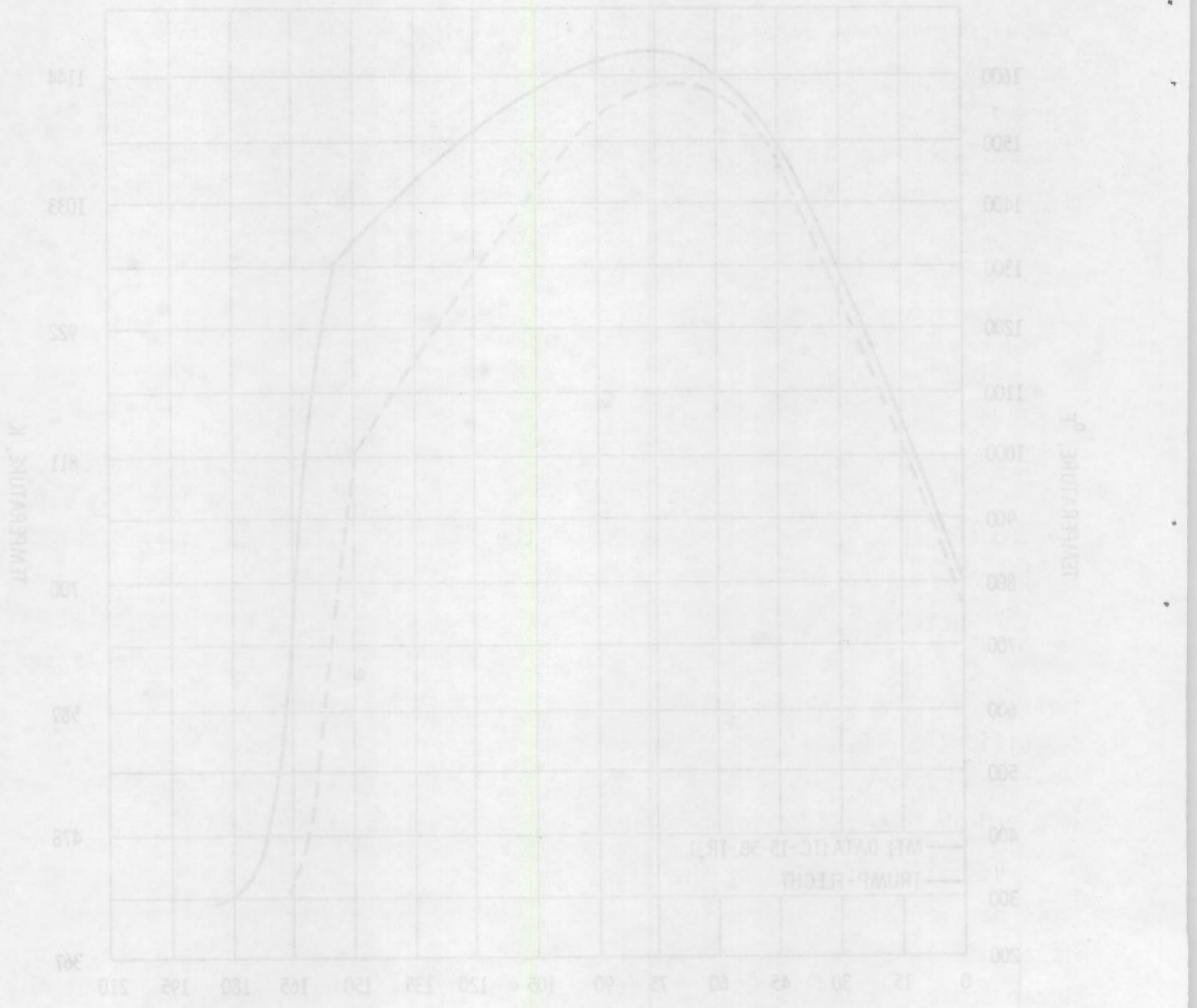

105.

natis

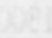

(1)
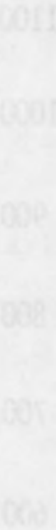


\subsection{VISUAL AND PHOTOGRAPHIC EXAMINATION}

The test train was placed on the Disassembly Examination and Reassembly Machine (DERM) approximately 10 days after removal from the NRU reactor for visual examination under $1.83 \mathrm{~m}(6.0 \mathrm{ft})$ of water at CRNL. The shroud appeared to be in good condition. Figure 5.1 shows a photograph of the shroud attached to the inlet nozzle with the $Z$ axis reference grid at 0.0 . Figure 5.2 shows the shroud and one of its interlocking clips at the $Z$ axis reference of $2.133 \mathrm{~m}$ ( $83.9 \mathrm{in.}$ ), which is near the initial fuel rod rupture zone. No shroud deformation was observed from this examination.

\subsection{GUARD FUEL ROD BUNDLE SUMMARY}

Side 1 of the shroud (Figure 1.1) was lifted off after the shroud interlocking clips were removed. Overall photographs were made by CRNL. Two of these are shown in Figure 5.3, which shows the bottom of the test train, and Figure 5.4, which shows the (undeformed) guard fuel rod bundle between spacer \#4 and spacer \#5. The latter region is the location of the fuel rod rupture, although the interior test fuel rods are not evident here. Additional photographs were taken of the side of the test train also showing the (undeformed) guard fuel rod bundle. Figure 5.5 shows the tie plate and the lower end of the fuel rod bundle with the $Z$ axis reference grid at 0.0 . Figure 5.6 is a higher magnification of the rupture region seen in Figure 5.4; it shows the side view near the rupture zone (though no damage is visible yet). Figure 5.7 shows the top end of the test train where instrumentation lines enter the fuel rods.

Visual examination of the guard fuel rod bundle indicated that some fuel rods may be slightly distorted (bowed). Because the distortion is so slight, it has been recomnended that the guard fuel rod bundle, shroud, and the test train can be reused.

\subsection{TEST FUEL ROD BUNDLE SUMMARY}

The guard fuel rod bundle was separated from the test train using a special lifting strongback. This permitted visual examination of the upper 
side (1) of the test fuel rod bundle. Both photographic and television examinations were made with the fuel rod bundles released from the tie plate on the disassembly station. Axial references on the test fuel bundle are approximate. Consequently, in the following photographs showing the rupture zone, the $Z$-axis dimension is located at 2.06 to $2.08 \mathrm{~m}$ ( 81 to $82 \mathrm{in.}$ ). Precise measurements were made later with fuel rods mounted on the DERM examination station.

Figure 5.8 (CRNL) shows an overview of the lower end of the test fuel rod bundle. Figure 5.9 shows the test fuel rod bundle between spacer \#4 and spacer \#5 (Level 13). Test fuel rod ruptures can be seen.

Side photographs of the bundle were made using the DERM periscope. With the $Z$ axis reference at 0.0 , Figure 5.10 shows the top of the lower tie plate [0.018 $\mathrm{m}$ ( $0.7 \mathrm{in.}$ ) below the bottom of the fuel column]. Figure 5.11 shows fragments of fuel pellets with the $Z$-axis reference at $1.78 \mathrm{~m}$ (70 in.). Figure 5.12 shows the fuel rod rupture zone with the $Z$-axis reference at $2.13 \mathrm{~m}$ (84 in.).

Photographs were also made looking down (side 1 - see Figure 1.1) on the test train using the DERM periscope. Figure $5.13^{(a)}$ shows the reference at the tie plate $(0.0)$ and Figure $5.14^{(a)}$ uses a reference at $2.13 \mathrm{~m}(84 \mathrm{in.})$ to show the fuel rod rupture zone from the top (side 1). Figure 5.15 and 5.16 are enlarged views of the fuel rod rupture area.

Dimensional results from the DERM measurements are summarized graphically in Appendix C. The system is now being qualified and calibrated. Data will be provided in a subsequent topical report.

(a) Figures 5.13 and 5.14 are mirror image photographs. 


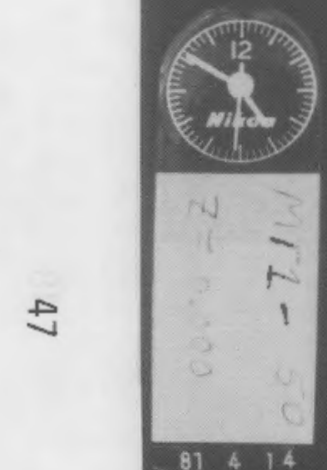

$\Longleftarrow Z \mathrm{ZAXIS}=0$ in.

$81+14$

\section{INLET NOZZLE}




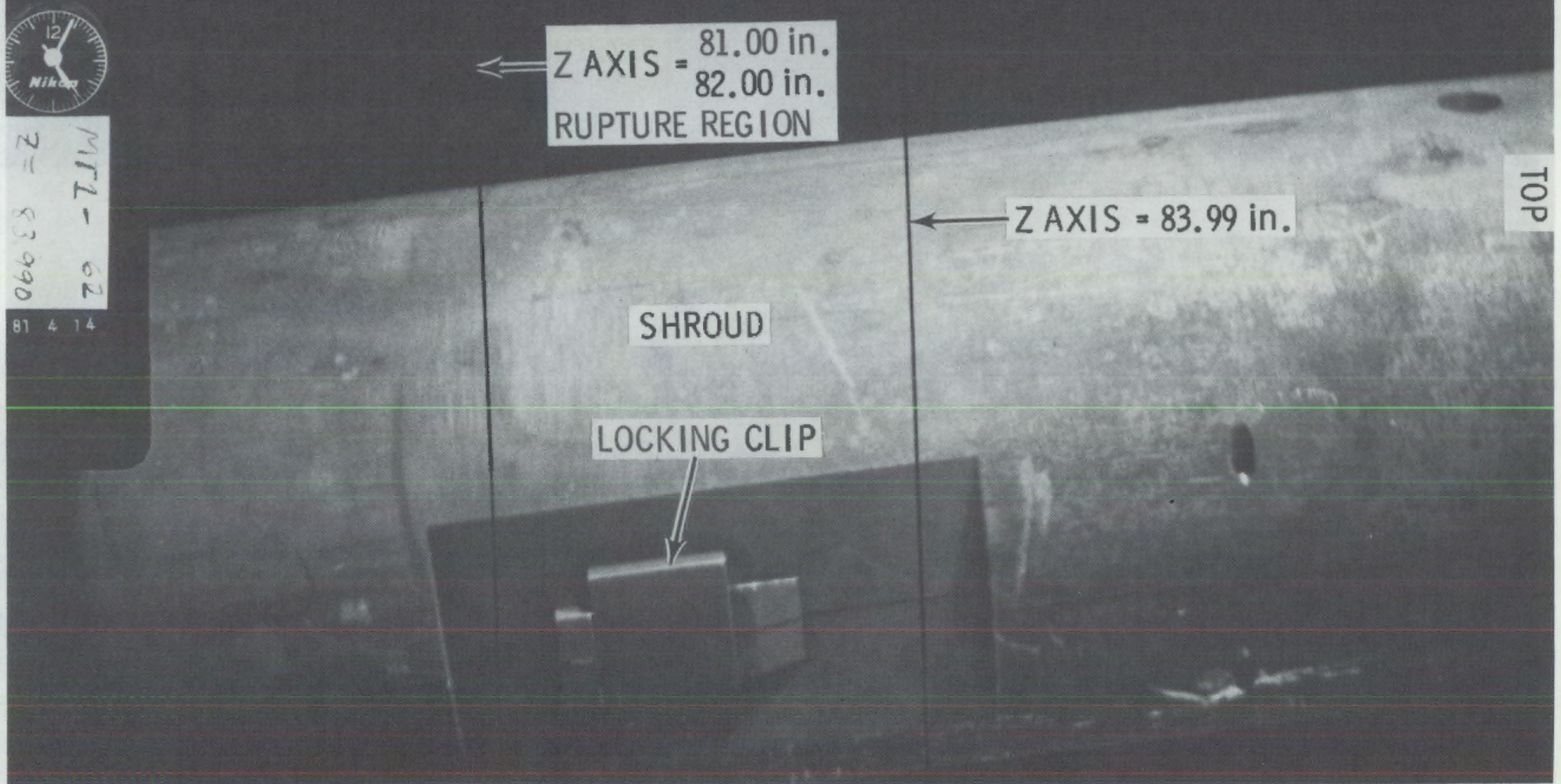

FIGURE 5.2. External Shroud and Locking Clip Near Level 13 


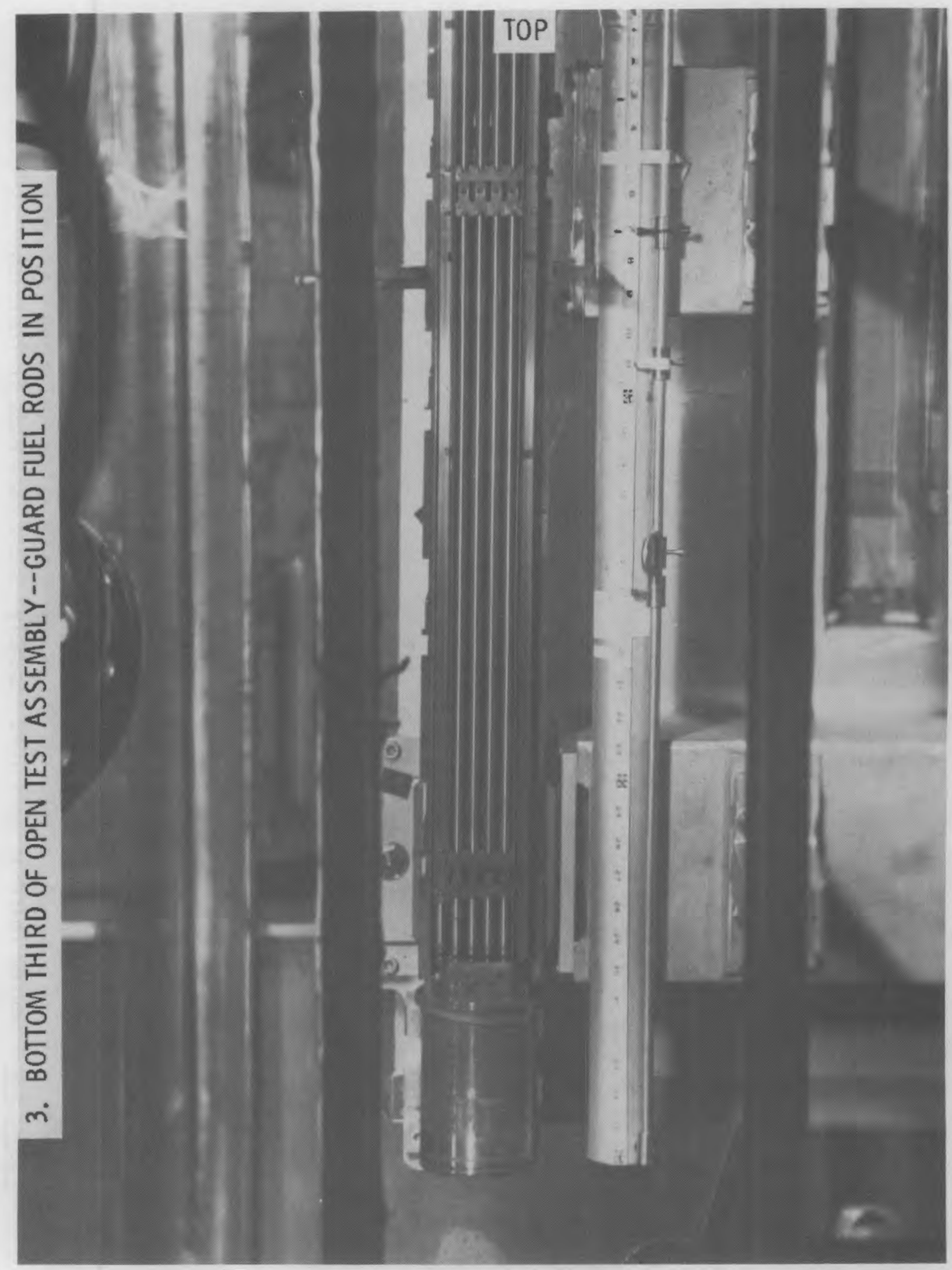

FIGURE 5.3. Bottom Third of Open Test Assembly-Guard Fuel Rods in Position 
4. CENTER THIRD OF OPEN TEST ASSEMBLY--GUARD FUEL RODS IN POSITION

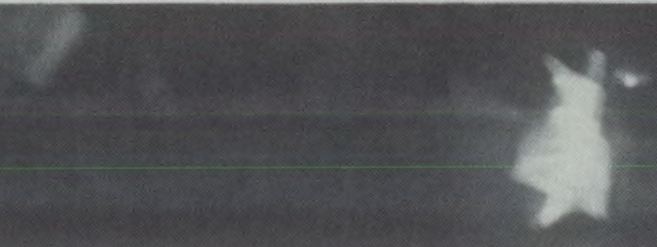

$\mathrm{ZAXIS}=77.00 \mathrm{in}$

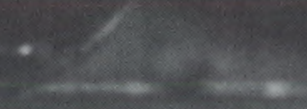

LEVEL 13
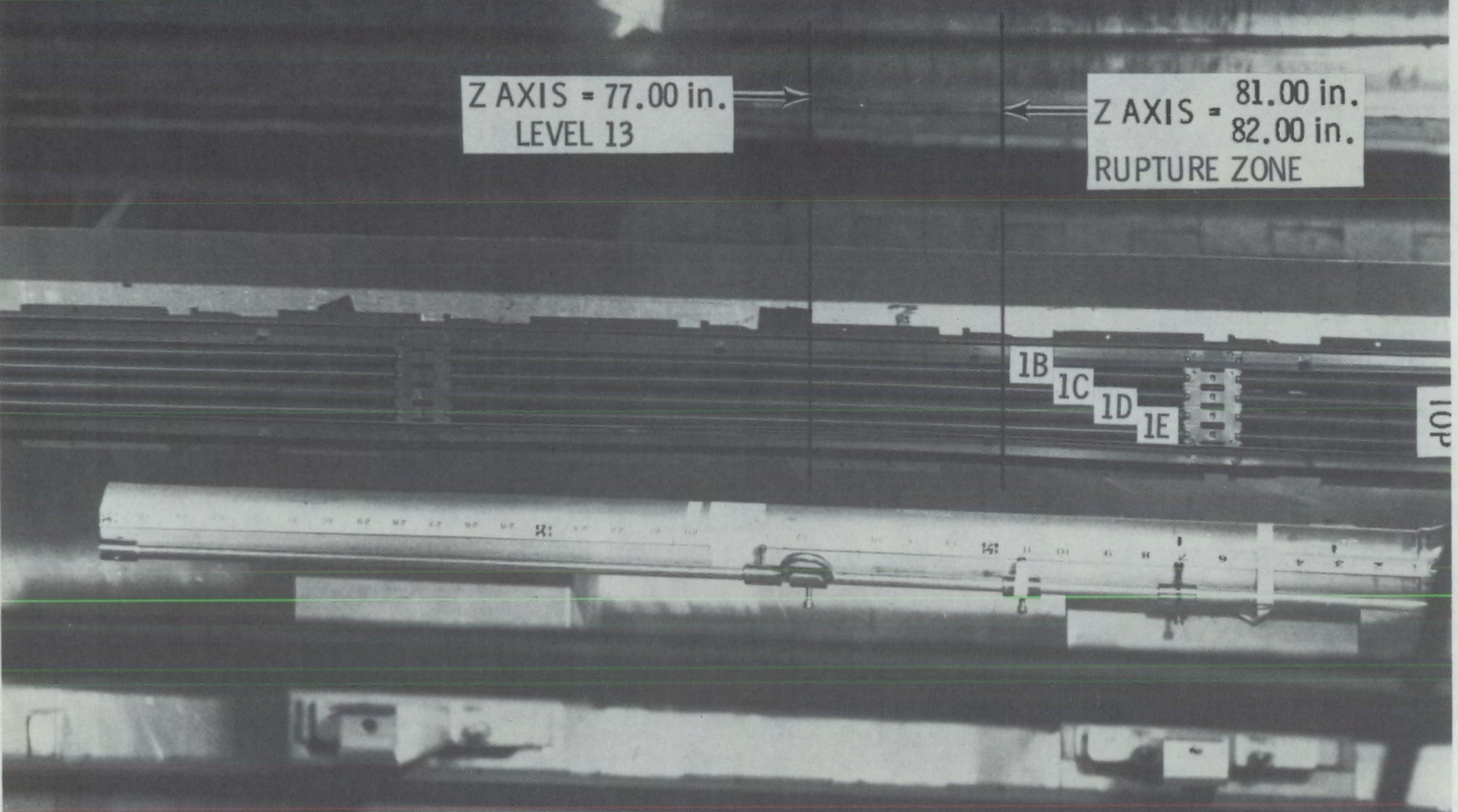

FIGURE 5.4. Center Third of Open Test Assembly--Guard Fuel Rods in Position 

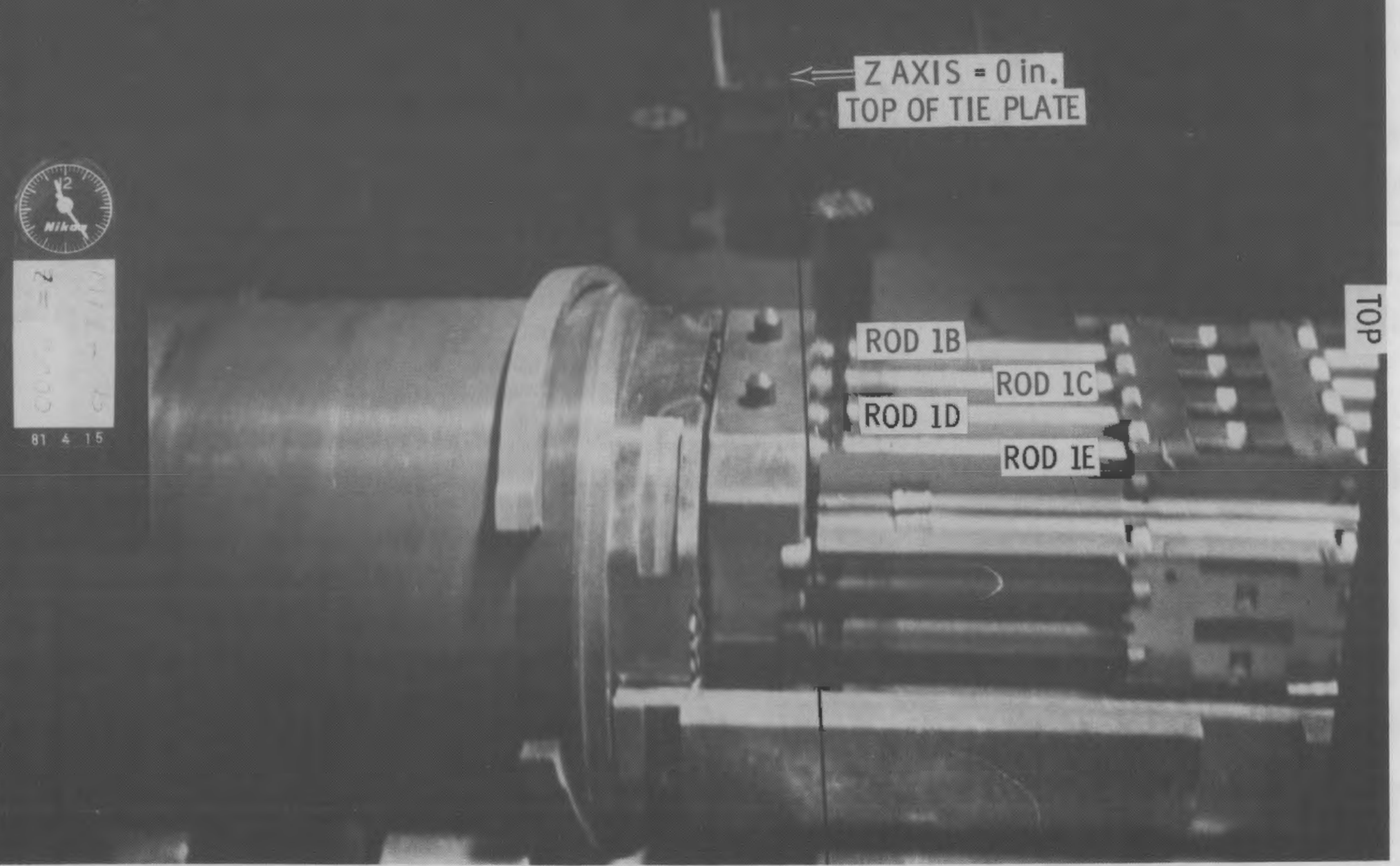

FIGURE 5.5. Side View of Guard Fuel Rods at Lower Tie Plate--Z $=0.0$ Reference 


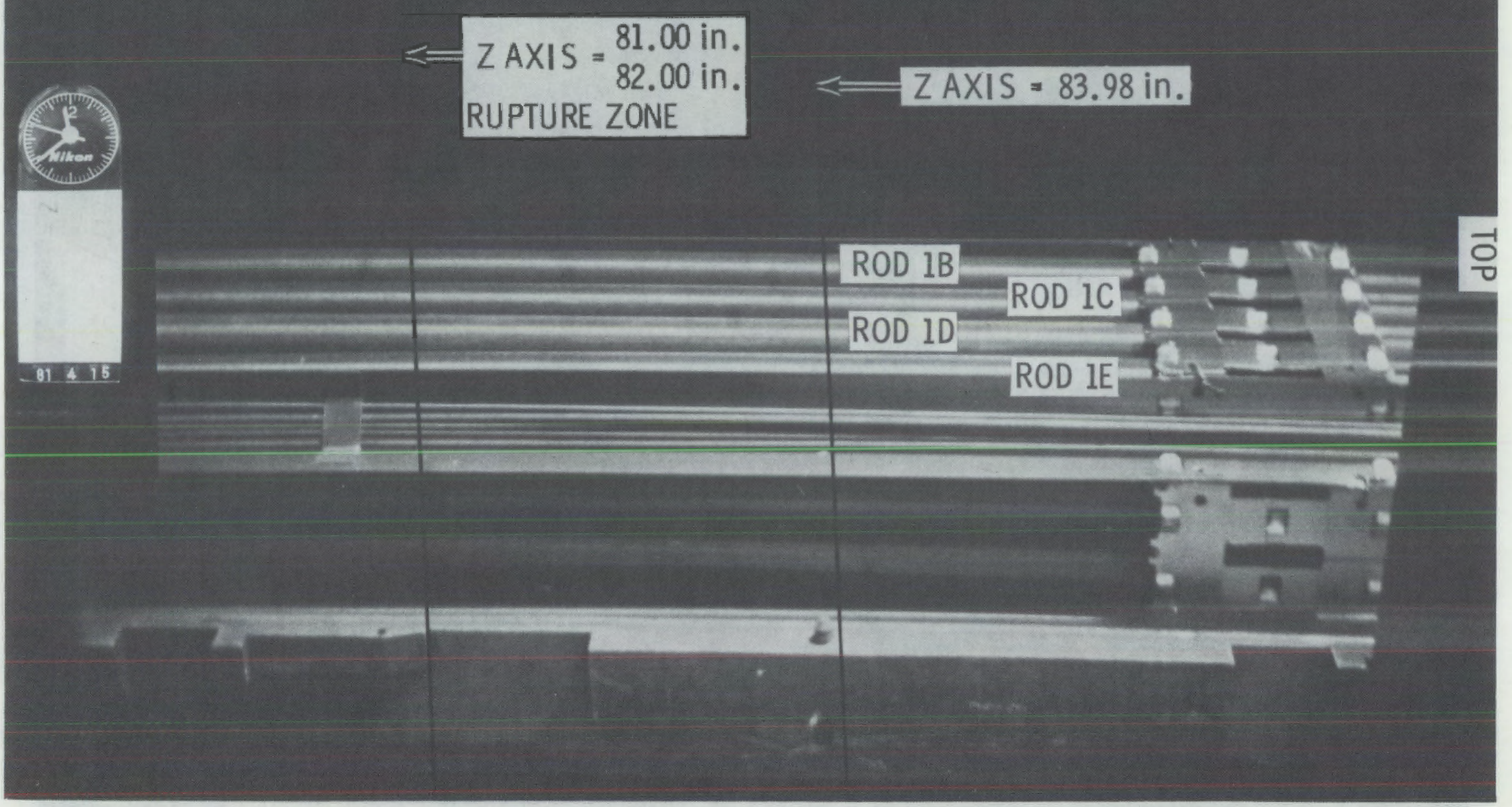

FIGURE 5.6. Side View of Guard Fuel Rods Where Internal Test Fuel Rods Ruptured 


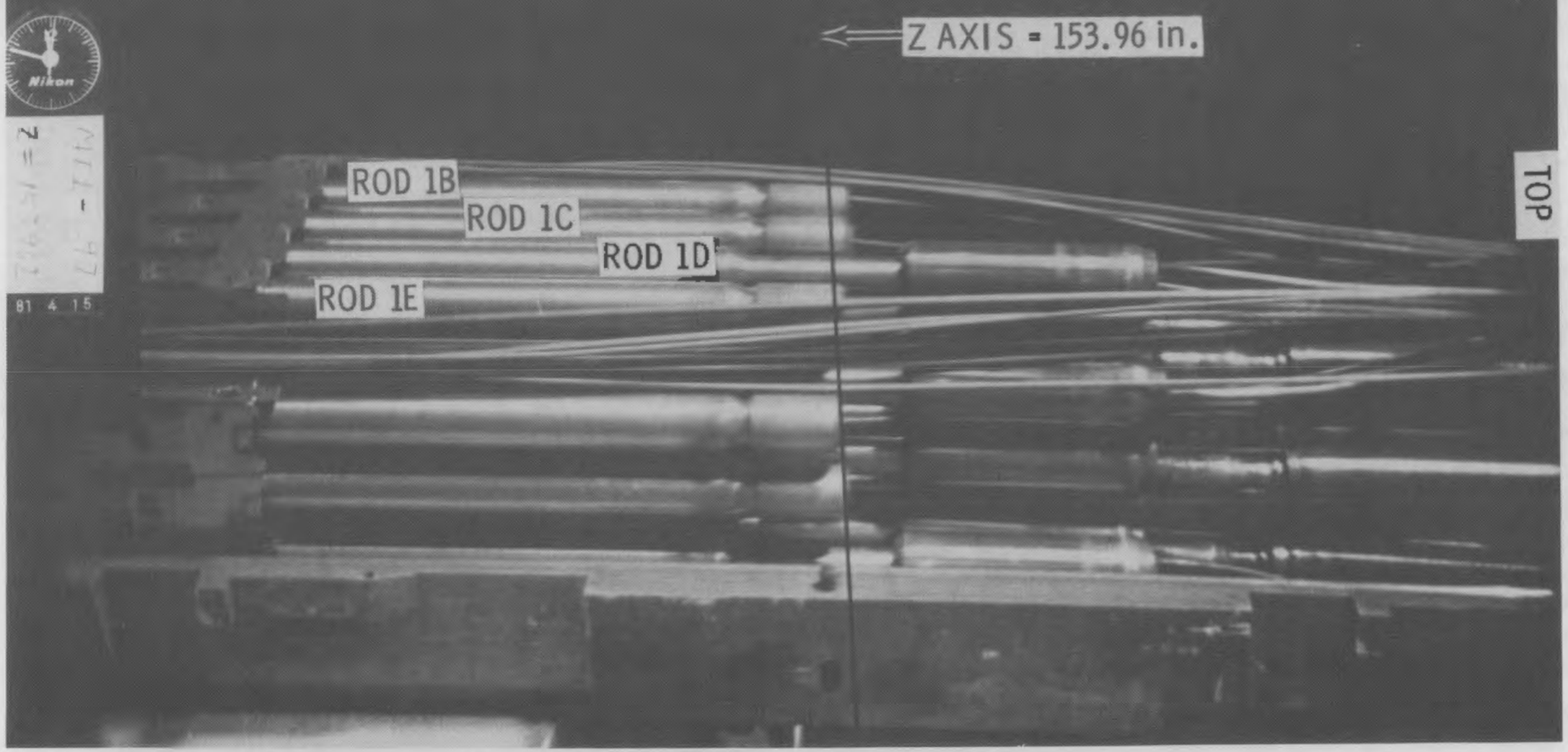

FIGURE 5.7. Side View of Test Assembly Upper End With Instrument Hard Lines 


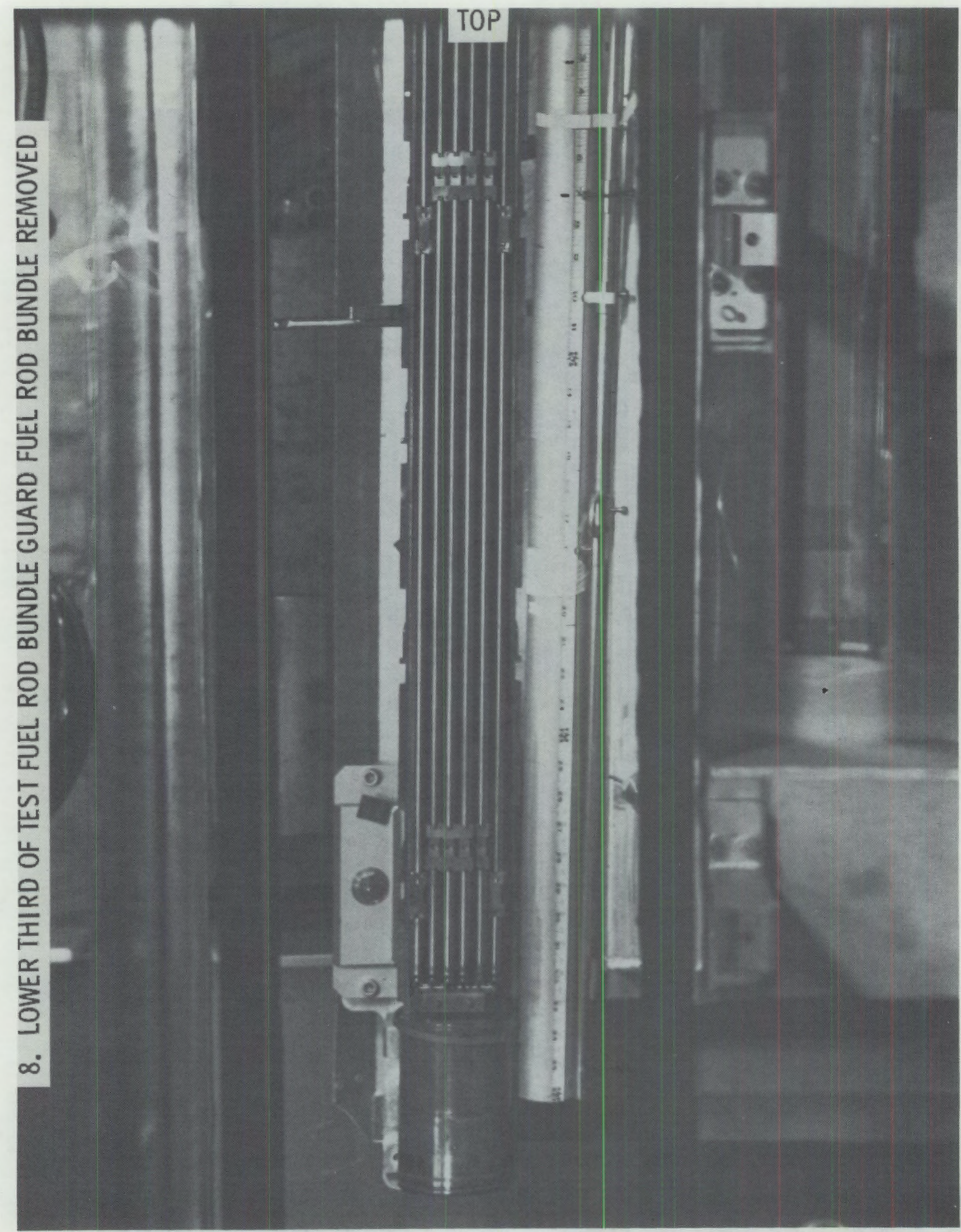

FIGURE 5.8. Lower Third of Test Fuel Rod Bundle-Guard Fuel Rod Bundle Removed 


\section{CENTER THIRD OF TEST FUEL ROD BUNDLE AND RUPTURE REGION}

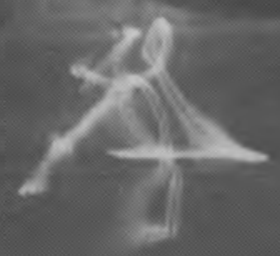

Z AXIS $=77.00$ in.
LEVEL 13

$\mathrm{ZAXIS}=81.00 \mathrm{in}$. RUPTURE ZONE

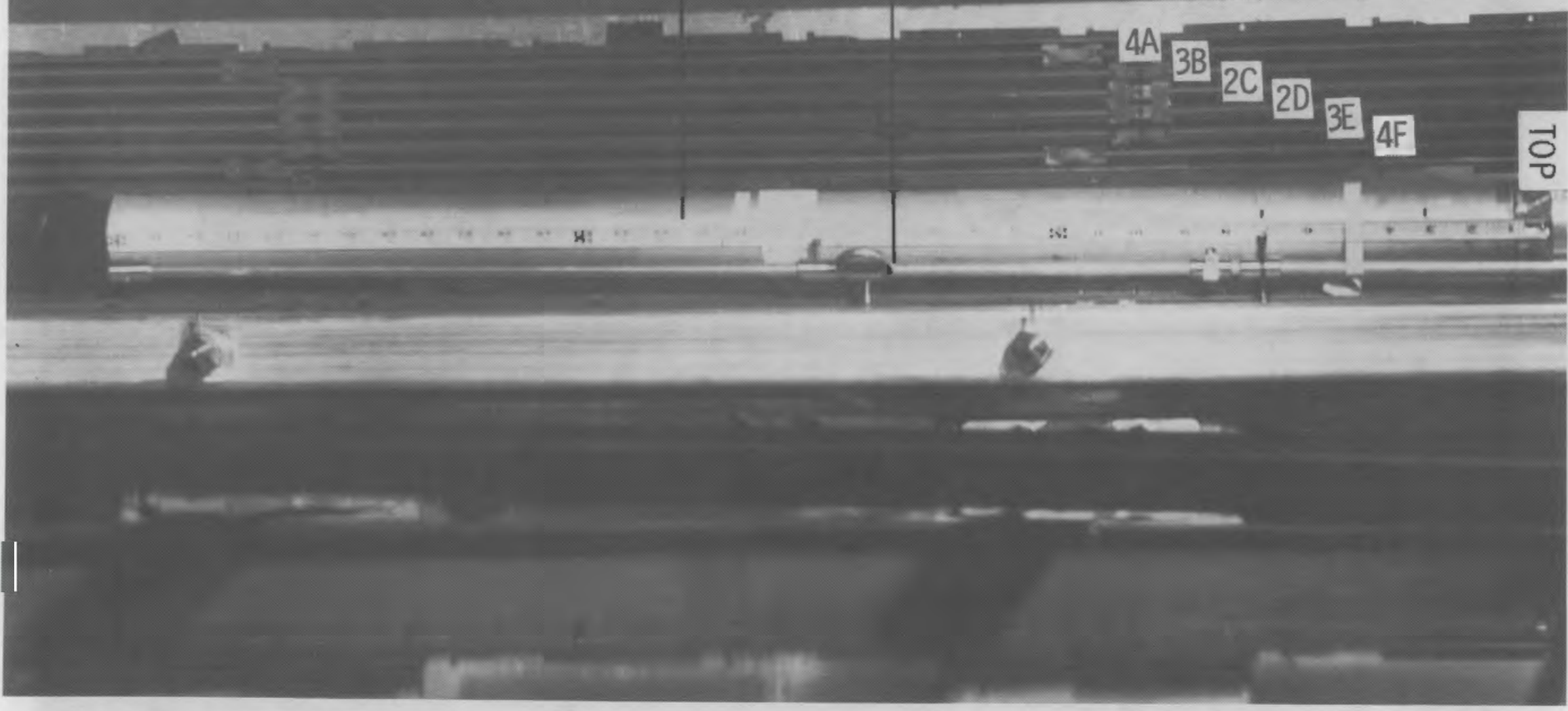

FIGURE 5.9. Center Third of Test Fuel Rod Bundle and Rupture Region 


\section{SIDE VIEW OF TEST FUEL RODS AT THE LOWER TIE PLATE $--Z=0.0$ REFERENCE}

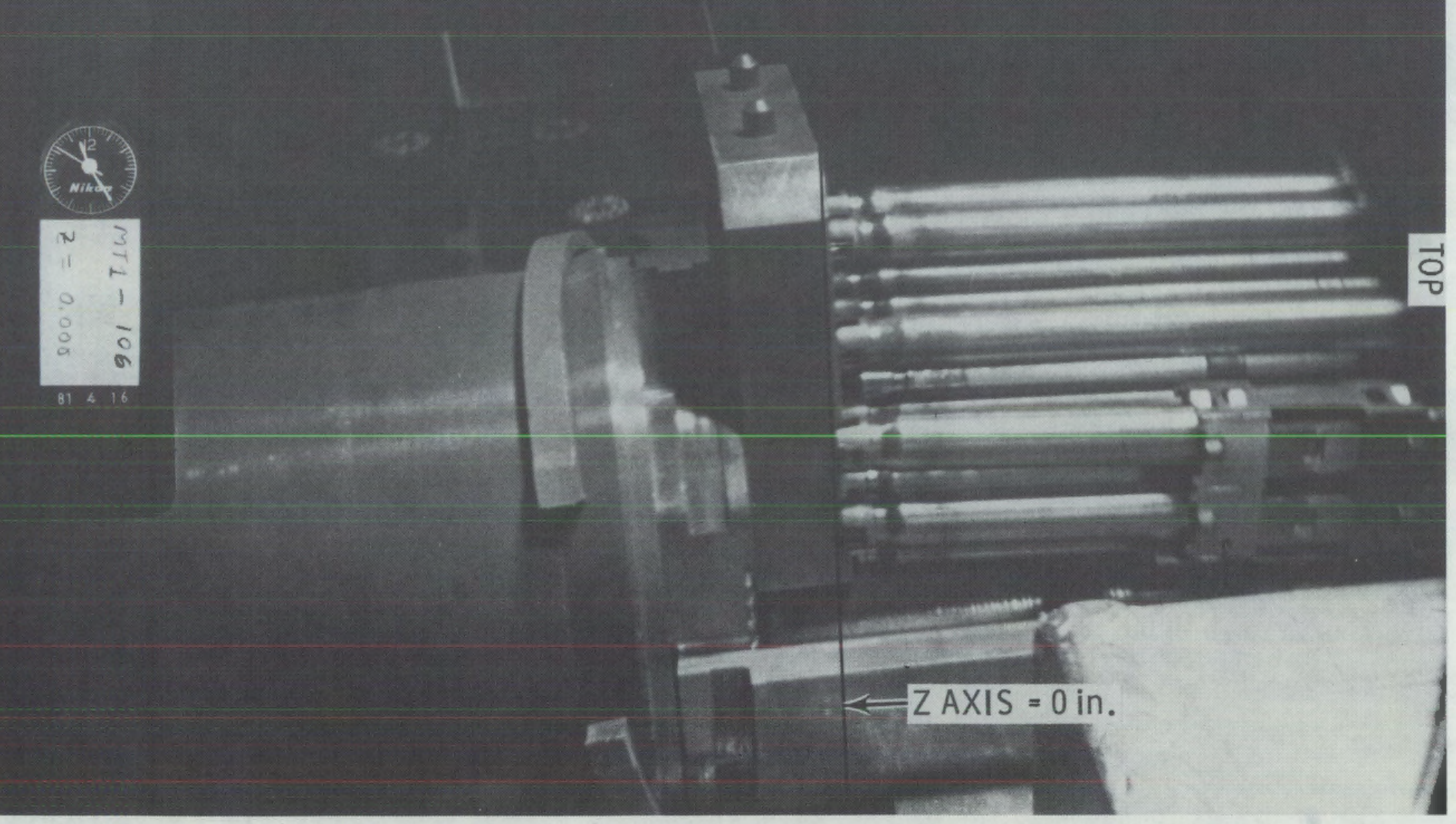

FIGURE 5.10. Side View of Test Fuel Rods at the Lower Tie Plate--Z $=0.0$ Reference 
g

$\overrightarrow{0}$ ROD 2C

ROD 2D

ROD 3E

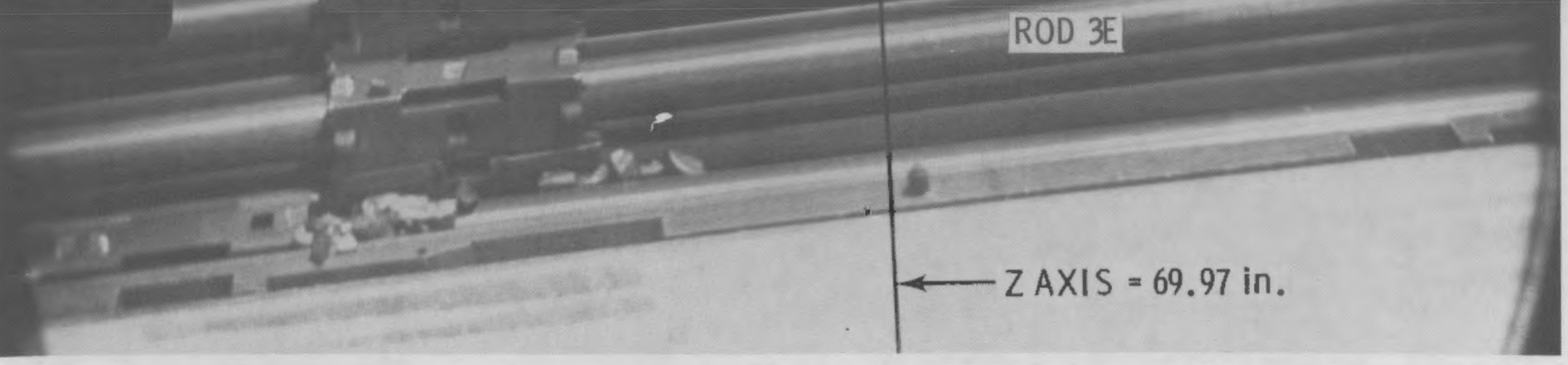

FIGURE 5.11. Side View of Test Fuel Rods With Fuel Pellet Fragments 


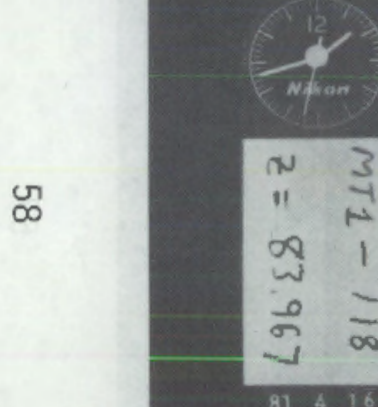

$$
\text { 1. }
$$
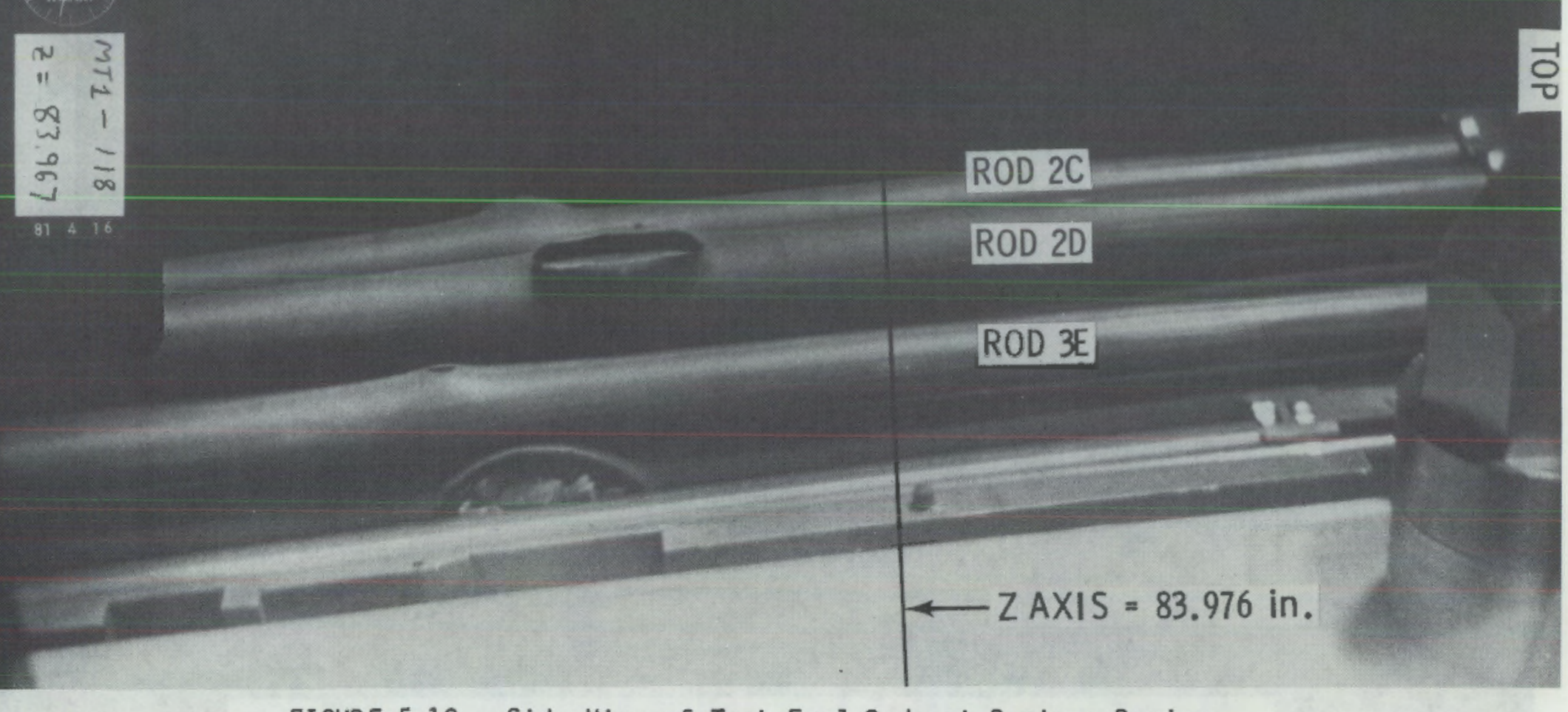

FIGURE 5.12. Side View of Test Fuel Rods at Rupture Region 


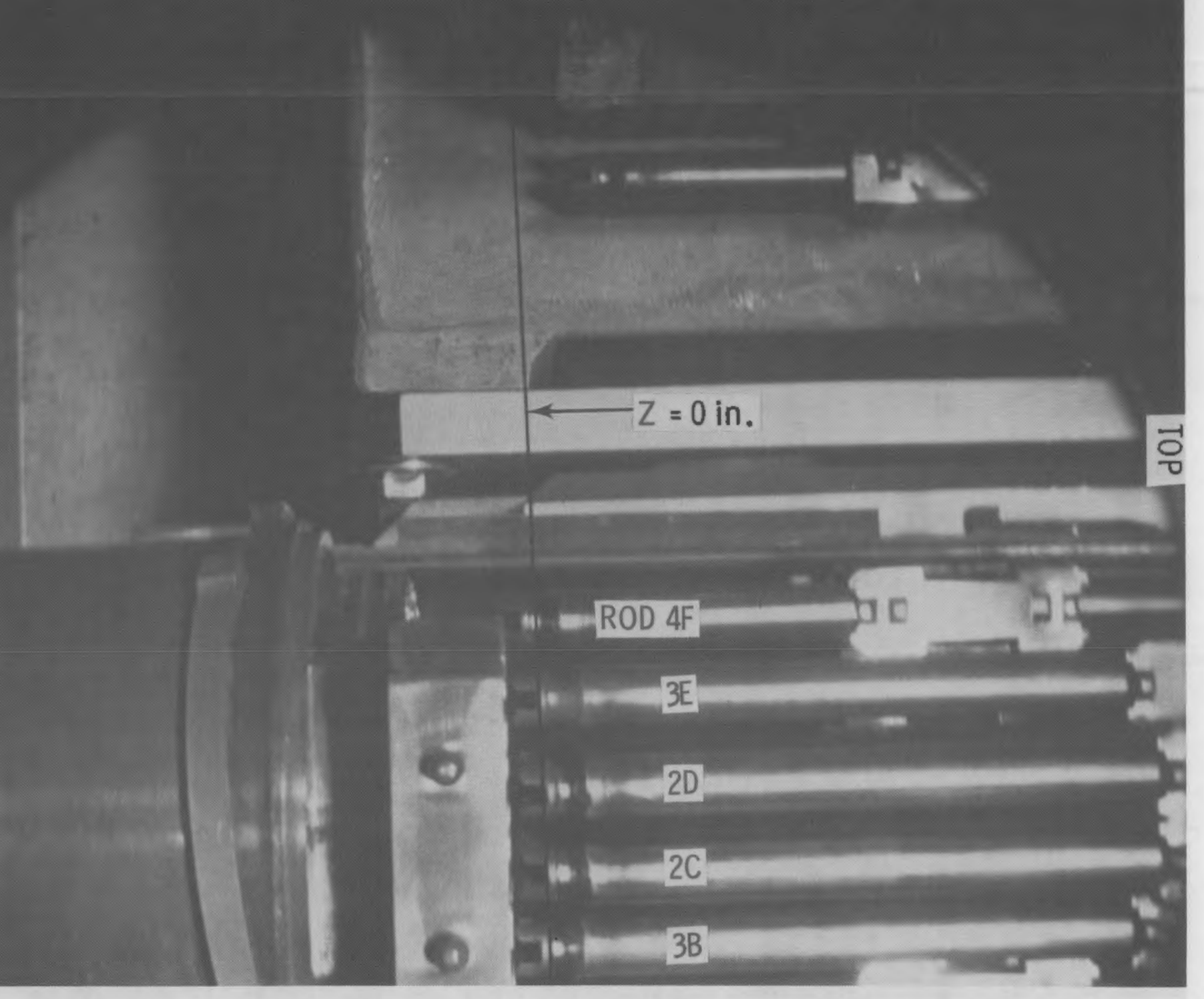

FIGURE 5.13. Top View of Test Fuel Rods at the Lower Tie Plate 


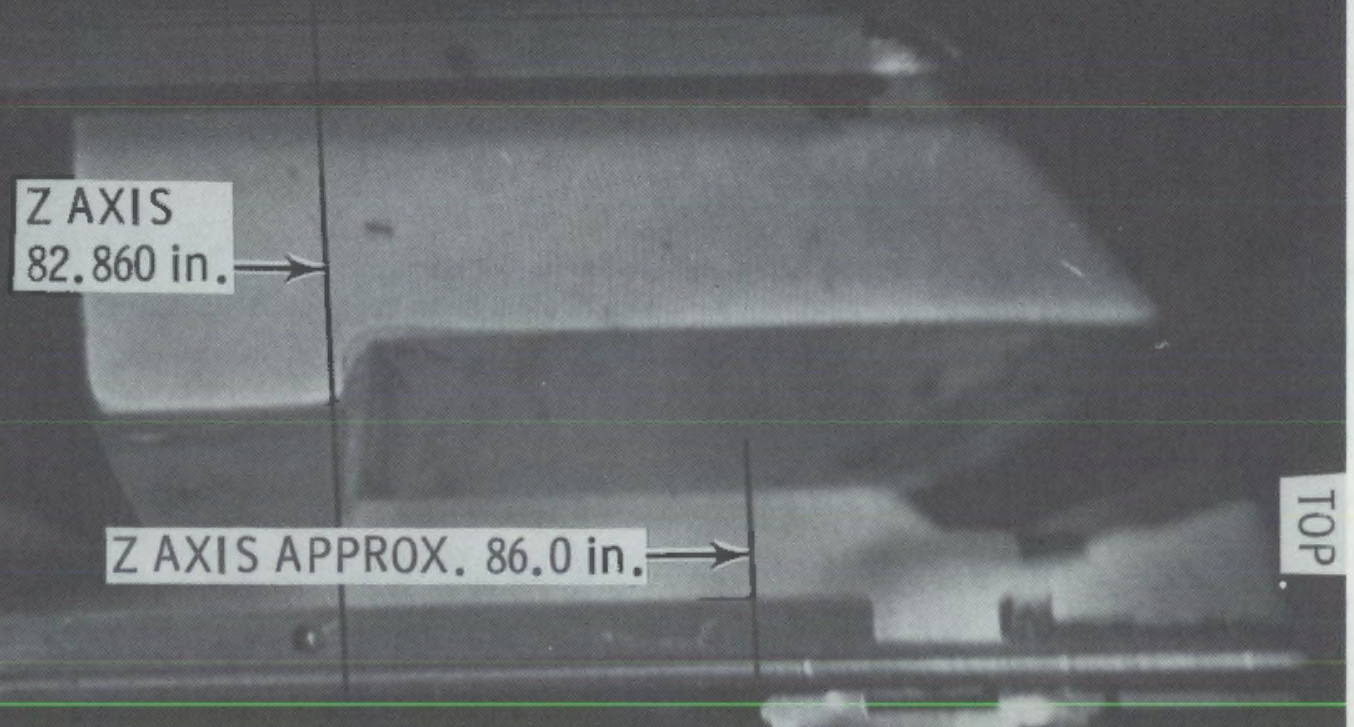

ROD 4F

3E

2D

$2 \mathrm{C}$

3B

FIGURE 5.14. Top View of Test Fuel Rods at the Fuel Rupture Region 


\section{CLOSEUP OF TEST FUEL ROD RUPTURE REGION}

\section{ROD 2C}

\section{ROD 2D}

2

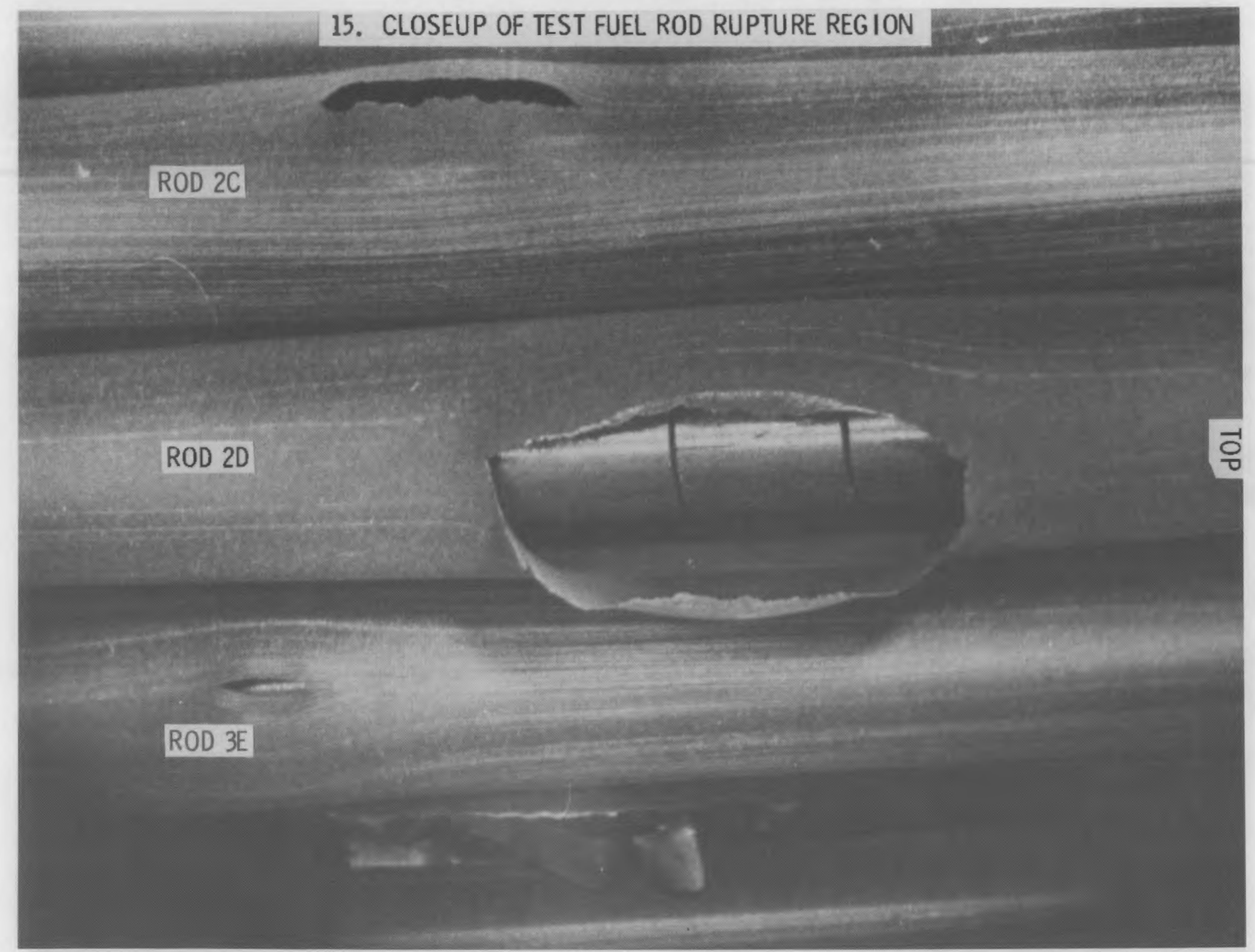

FIGURE 5.15. Closeup of Test Fuel Rod Rupture Region 


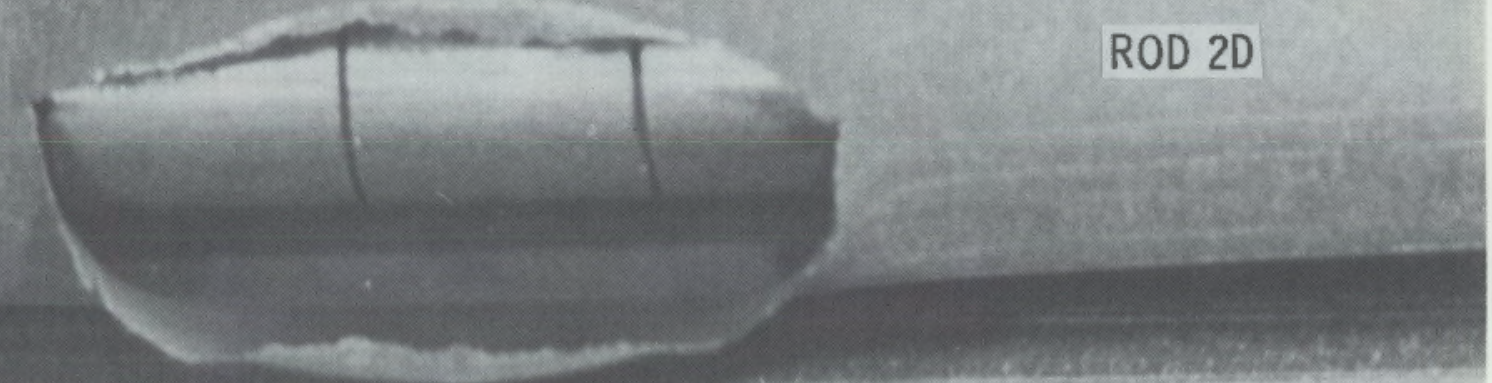

ROD 3E

ROD 4F

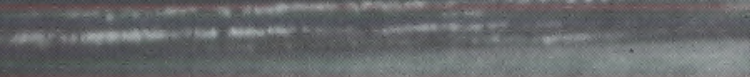

FIGURE 5.16. Closeup of Test Fuel Rod Rupture Region 


\subsection{REFERENCES}

1. Hann, C. R. 1979. "Program Plan for LOCA Simulation in the National Research Universal (NRU) Reactor." PNL-3056, Pac if ic Northwest Laboratory, Richland, Washington.

2. Mohr, C. L., et al. 1980. "Prototypic Thermal-Hydraulic Experiments in NRU to Simulate Loss-of-Coolant Accidents." PNL-3681, NUREG/CR-1882, Pacific Northwest Laboratory, Richland, Washington.*

3. Russcher, G. E., et a1. 1981. "Experiment Operations P1an for Loss-of-Coolant Accident Simulation in the National Research Universal Reactor. Addendum 1: Materials Tests 1 and 2." PNL-3765, NUREG/CR-1735, Add. 1, Pacific Northwest Laboratory, Richland, Washington.*

4. Russcher, G. E., et al. 1980. "Experiment Operations Plan for Loss-of-Coolant Accident Simulation in the National Research Universal Reactor." NUREG/CR-1735, PNL-3551, Pacific Northwest Laboratory, Richland, Washington.*

5. Heaberlin, S. W., et al. 1979. "Design Basis Neutronics Calculations for NRU LOCA Experiments." PNL-3113, Pacific Northwest Laboratory, Richland, Washington.

6. Siefken, L. J., M. P. Bohn, S. O. Peck, and J. A. Dearien. June 1979. "FRAP-T5: A Computer Code for the Transient Analys is of Oxide Fuel Rods." NUREG/CR-0840, TREE-1282, EG\&G Idaho, Inc.*

7. Mohr, C. L., D. D. Lanning, F. E. Panisko, and W. N. Rausch. May 1979. "GAPCON-THERMAL-3: A Technique for Evaluation of Transient Gap Conductance and Stored Energy." PNL-SA-7712, SMIRT-V, D-6/3, Battelle Pacific Northwest Laboratory.

8. Lilly, G. P., et al. 1977. "PWR FLECHT Cosine Low Flooding Rate Test Series Evaluation Report." WCAP-7931, Westinghouse Electric Corporation.

*AvaiTable for purchase from the NRC/GPO Sales Program, U.S. Nuclear Regulatory Commission, Washington, DC 20555 and/or the National Technical Information Service, Springfield, VA 22161. 

APPENDIX A

MT-1 GRAPHICAL DATA

Section 1 Temperature

1.1 Preconditioning

1.2 Pretransient and Transient

Section 2 Neutron Flux

2.1 Preconditioning

2.2 Pretransient and Transient

Section 3 Steam Probe Temperatures

3.1 Preconditioning

3.2 Pretransient and Transient

Section 4 Flow Test Reflood

4.1 Flow Rate

4.2 Steam Probe Temperatures

Section 5 MT-1 Transient Reflood

5.1 Flow Rate

5.2 Steam Probe Temperatures

(See Section 3.2)

Section 6 Fuel Rod Pressure

6.1 Pressure Transducers

6.2 Pressure Switches 
SECTION 1

TEMPERATURE DATA 


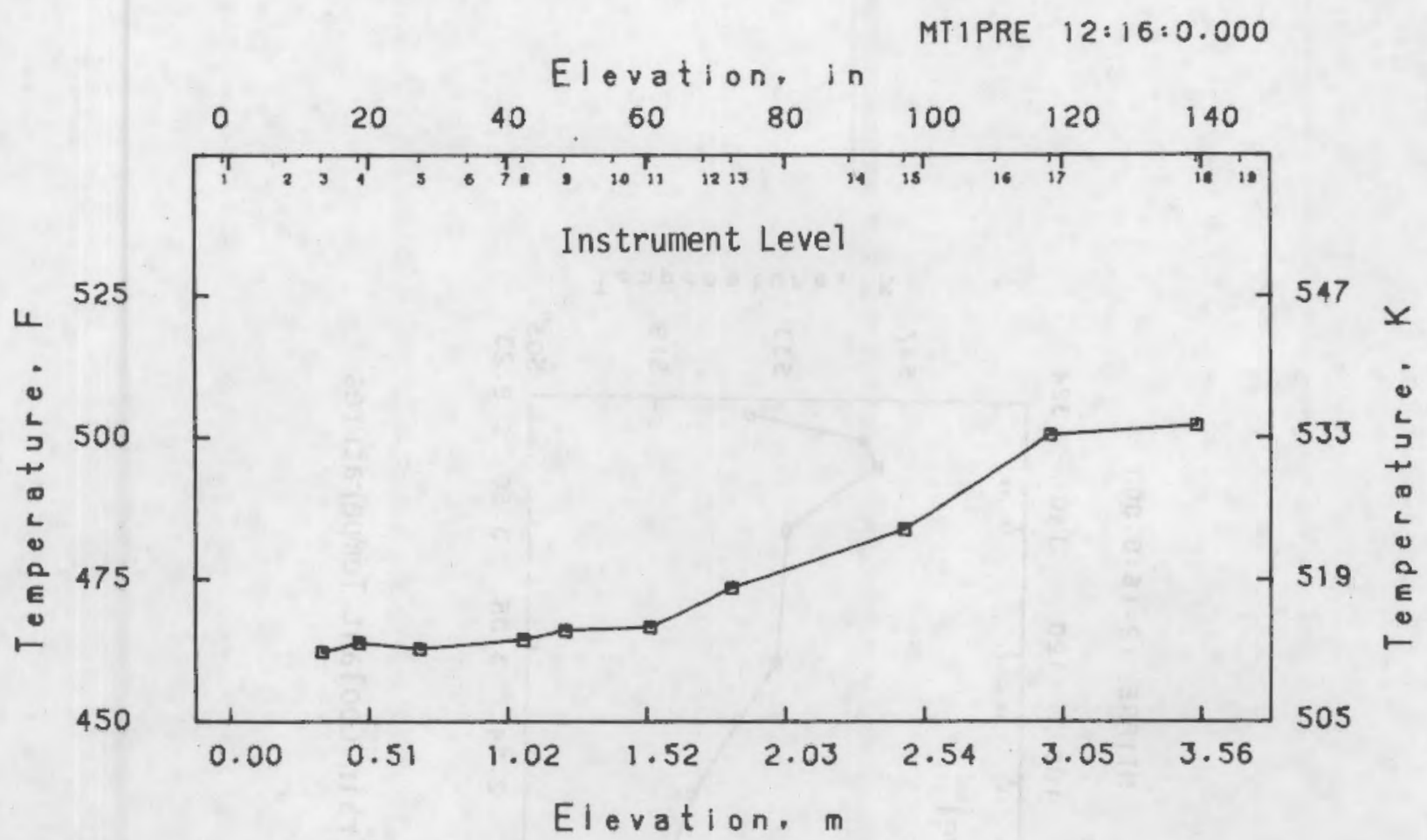

FIGURE A.1.1.1.1. Average Shroud Axial Temperature Profile

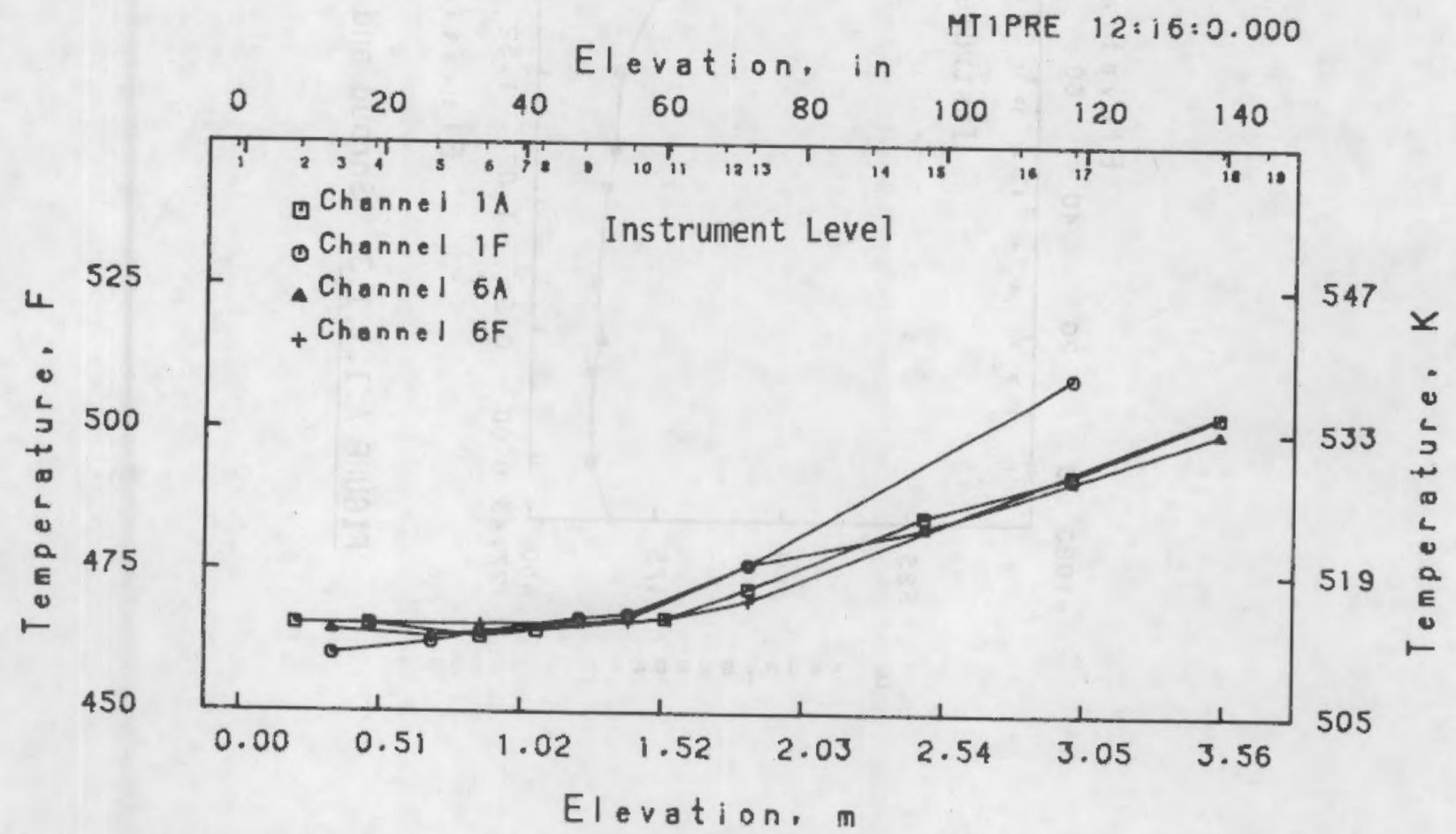

FIGURE A.1.1.1.2. Shroud Axial Temperature Profiles 


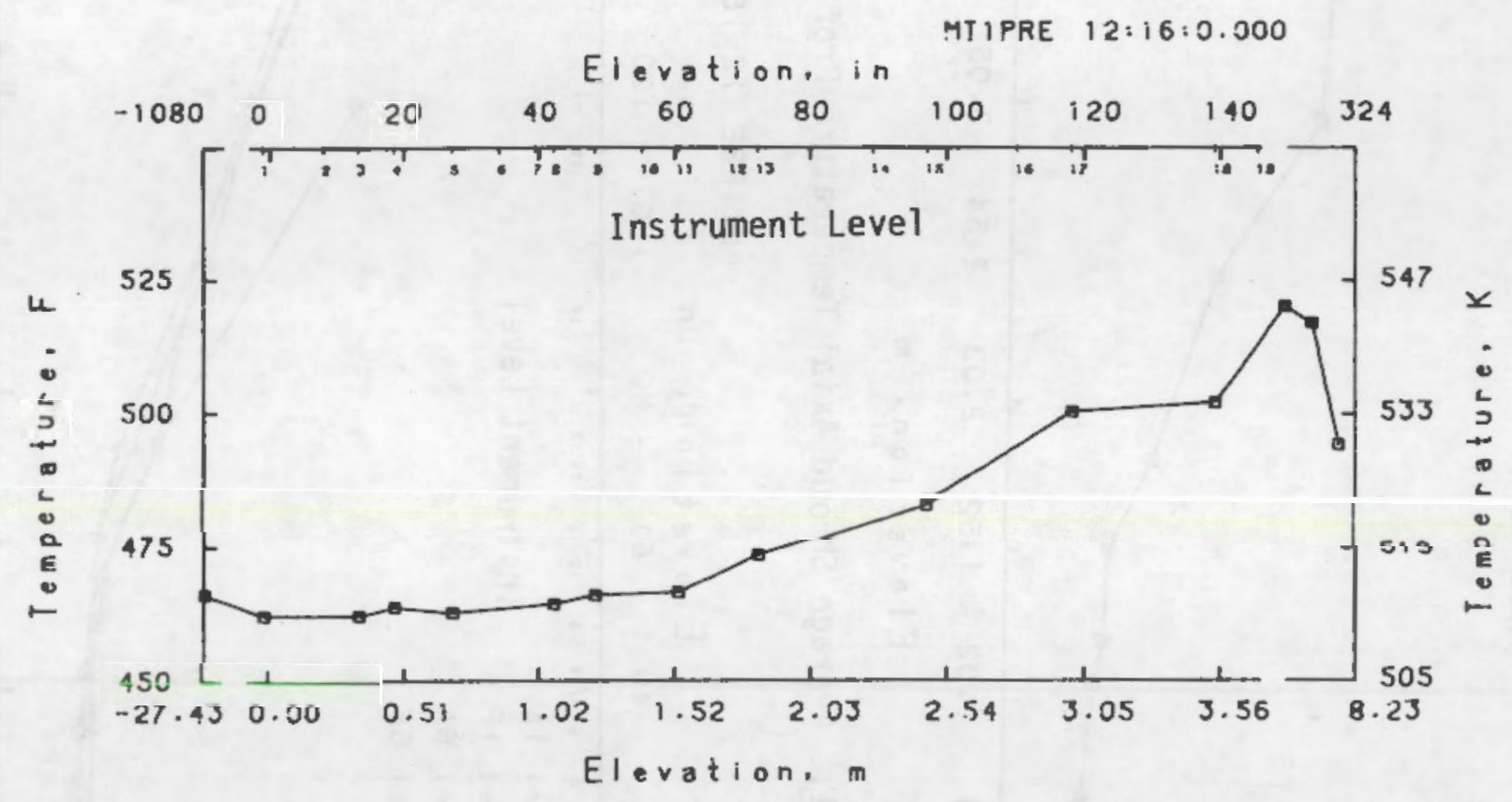

FIGURE A.1.1.1.3. Shroud and Test Train Coolant Temperatures 


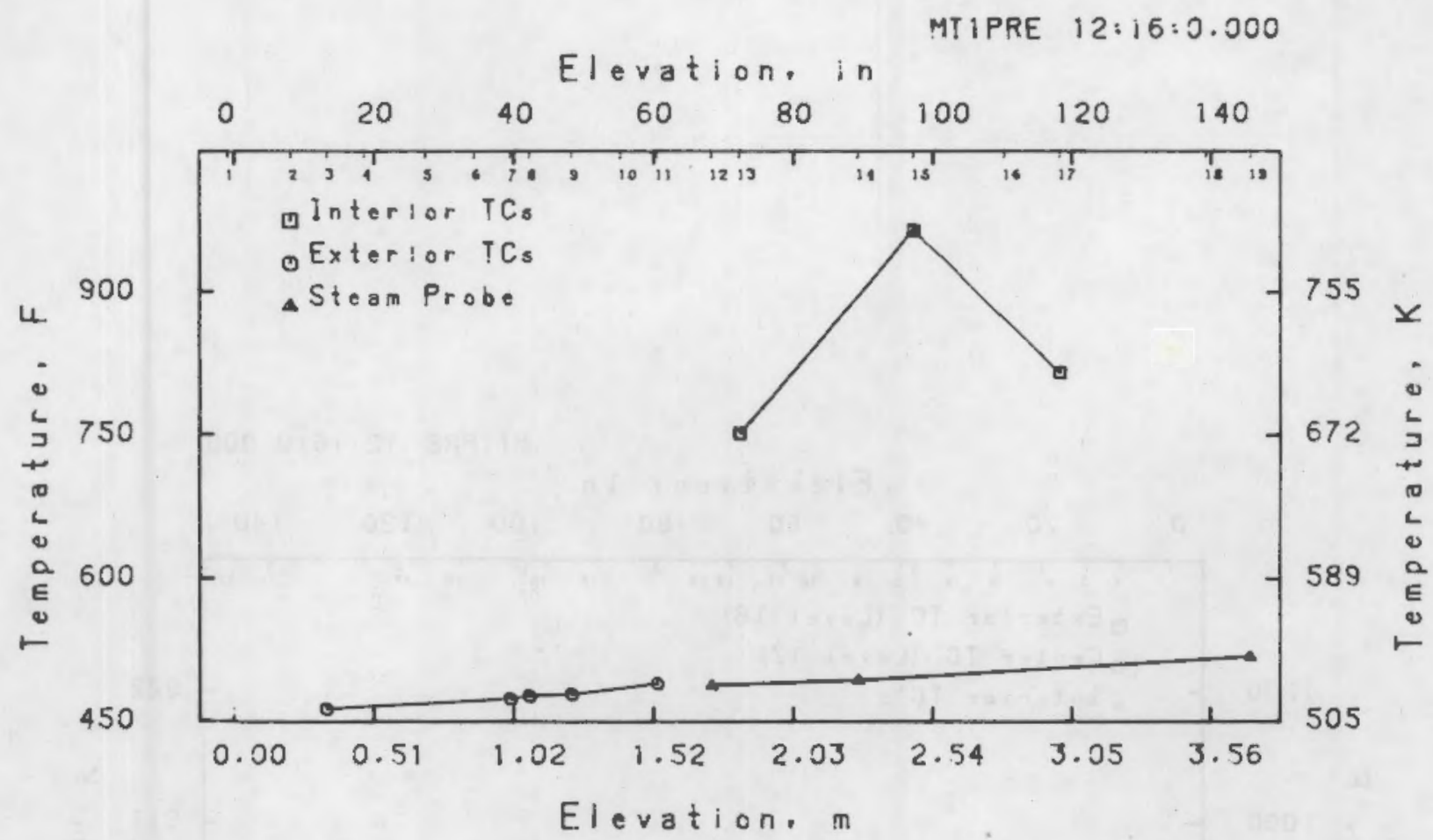

FIGURE A.1.1.2.1. Average Guard Fuel Rod $\mathrm{Cl}$ adding Temperature Profiles-Interior and Exterior TC's, Preconditioning MT-1

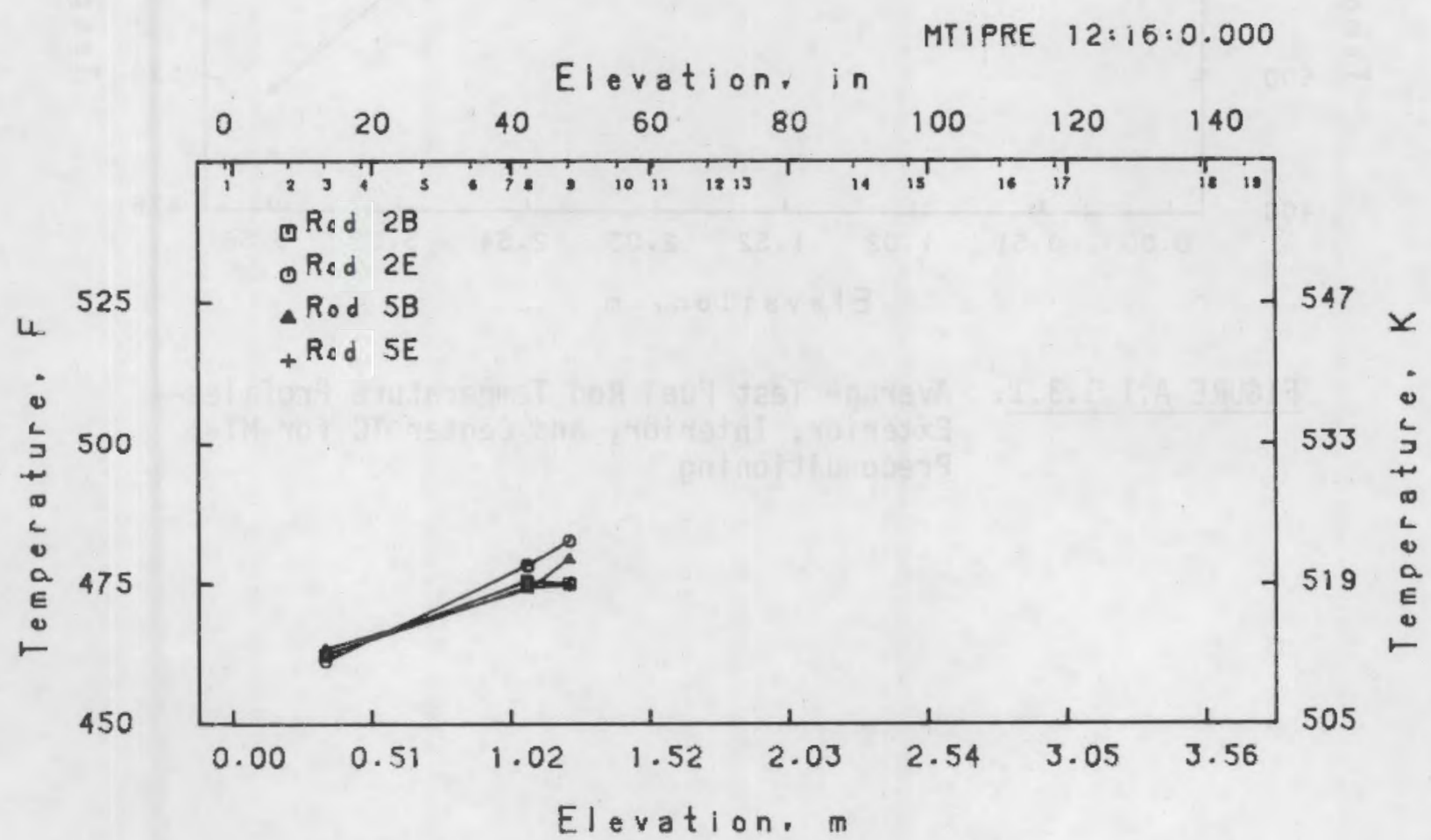

FIGURE A.1.1.2.2. Individual Guard Fuel Rod Cladding Exterior Temperature Profiles During Preconditioning 


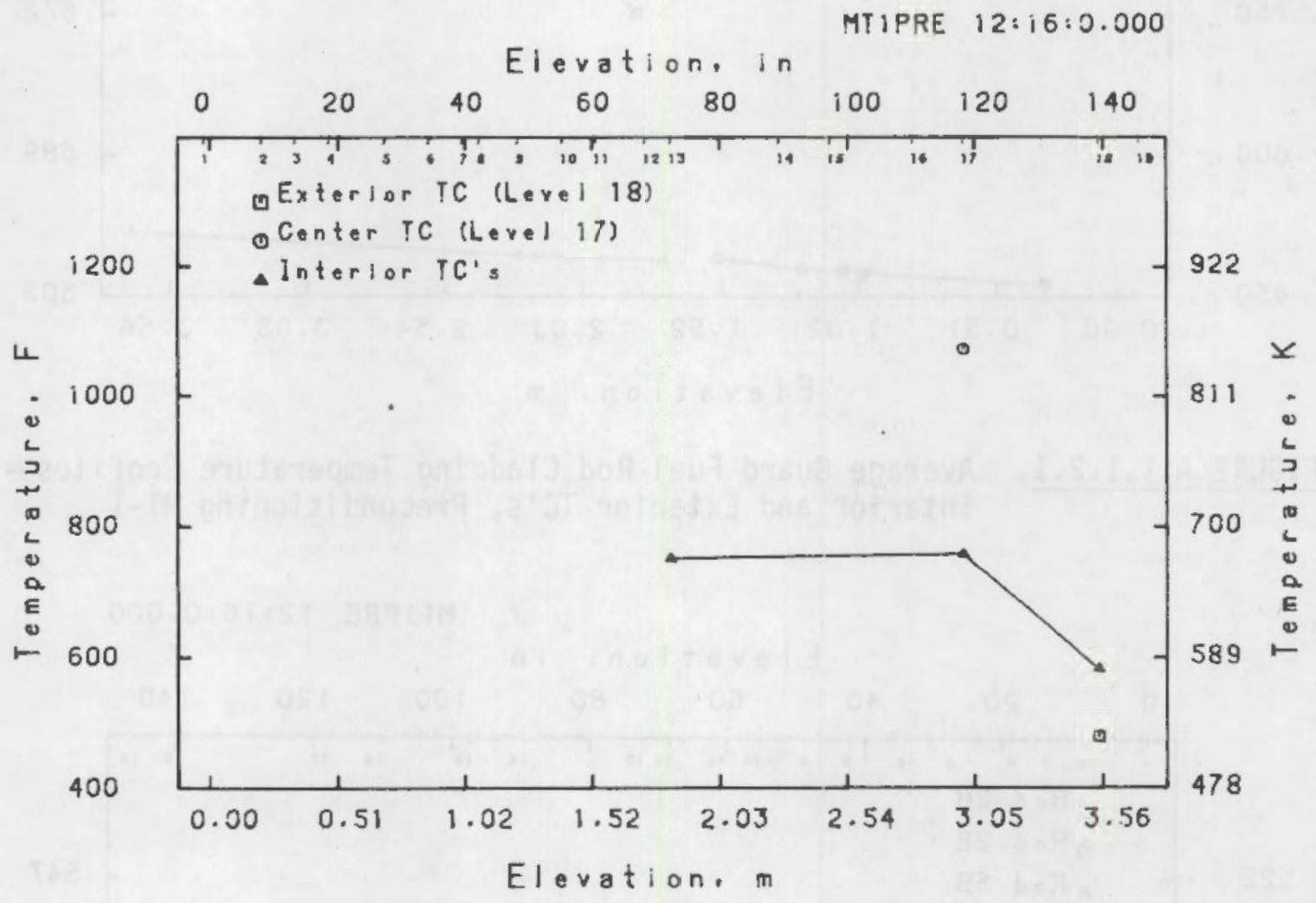

FIGURE A.1.1.3.1. Average Test Fuel Rod Temperature Profiles-Exterior, Interior, and Center TC for MT-1 Preconditioning 


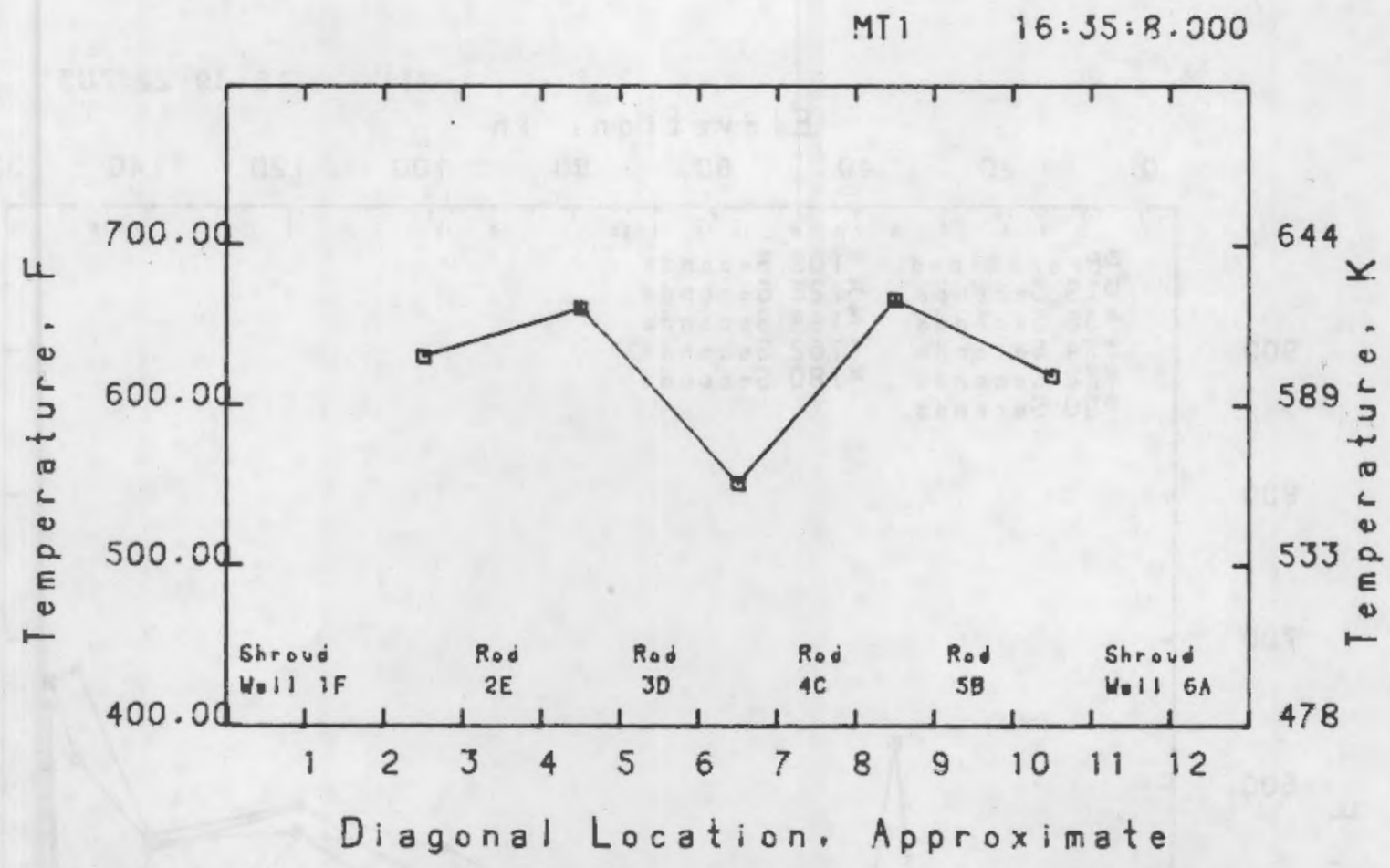

FIGURE A.1.2.1.1. Diagonal Temperature Profile Across Test Assembly Coolant During Pretransient - Level 16

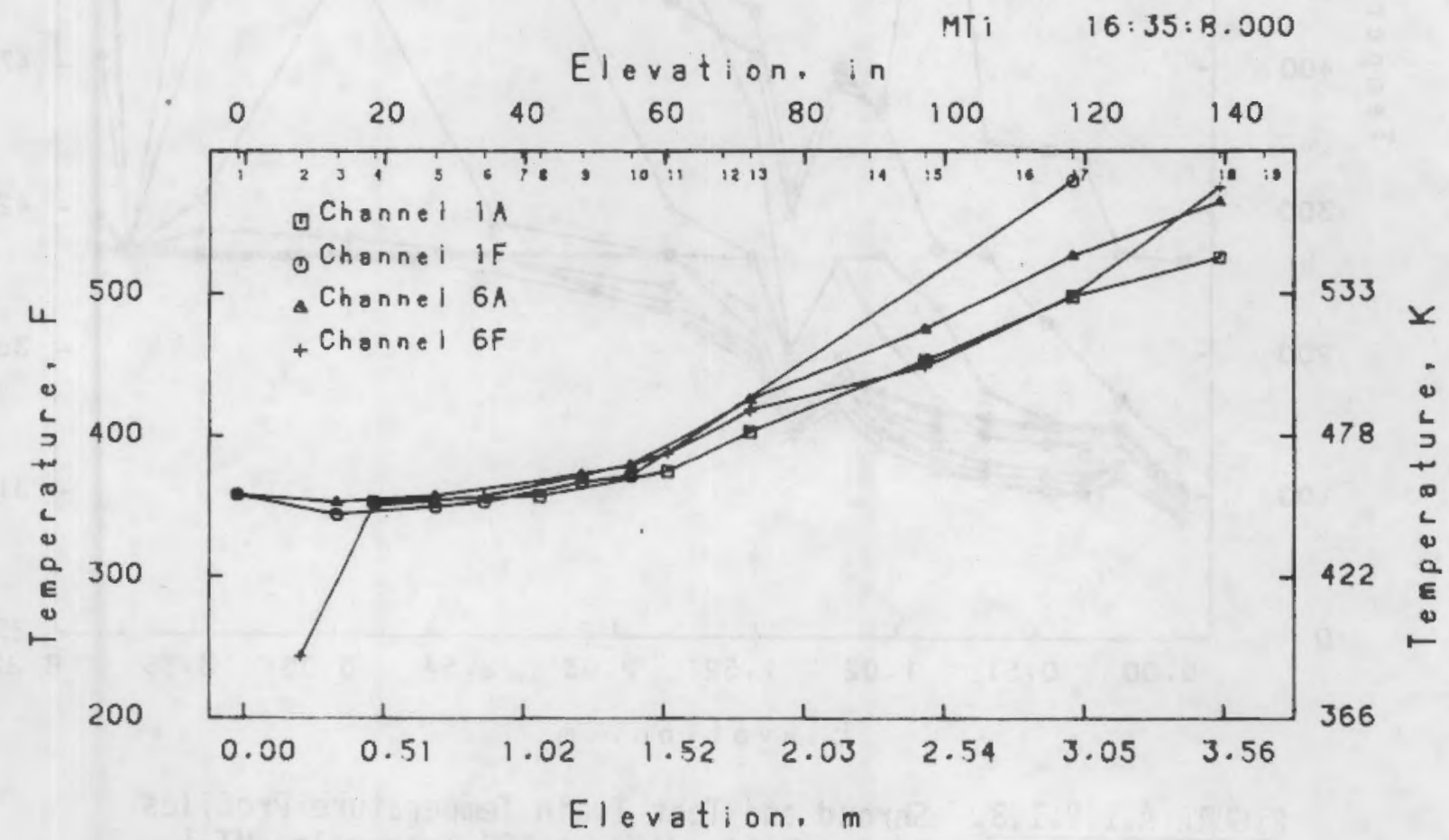

FIGURE A.1.2.1.2. Shroud Axial Temperature Profiles--

Pretransient MT-1 


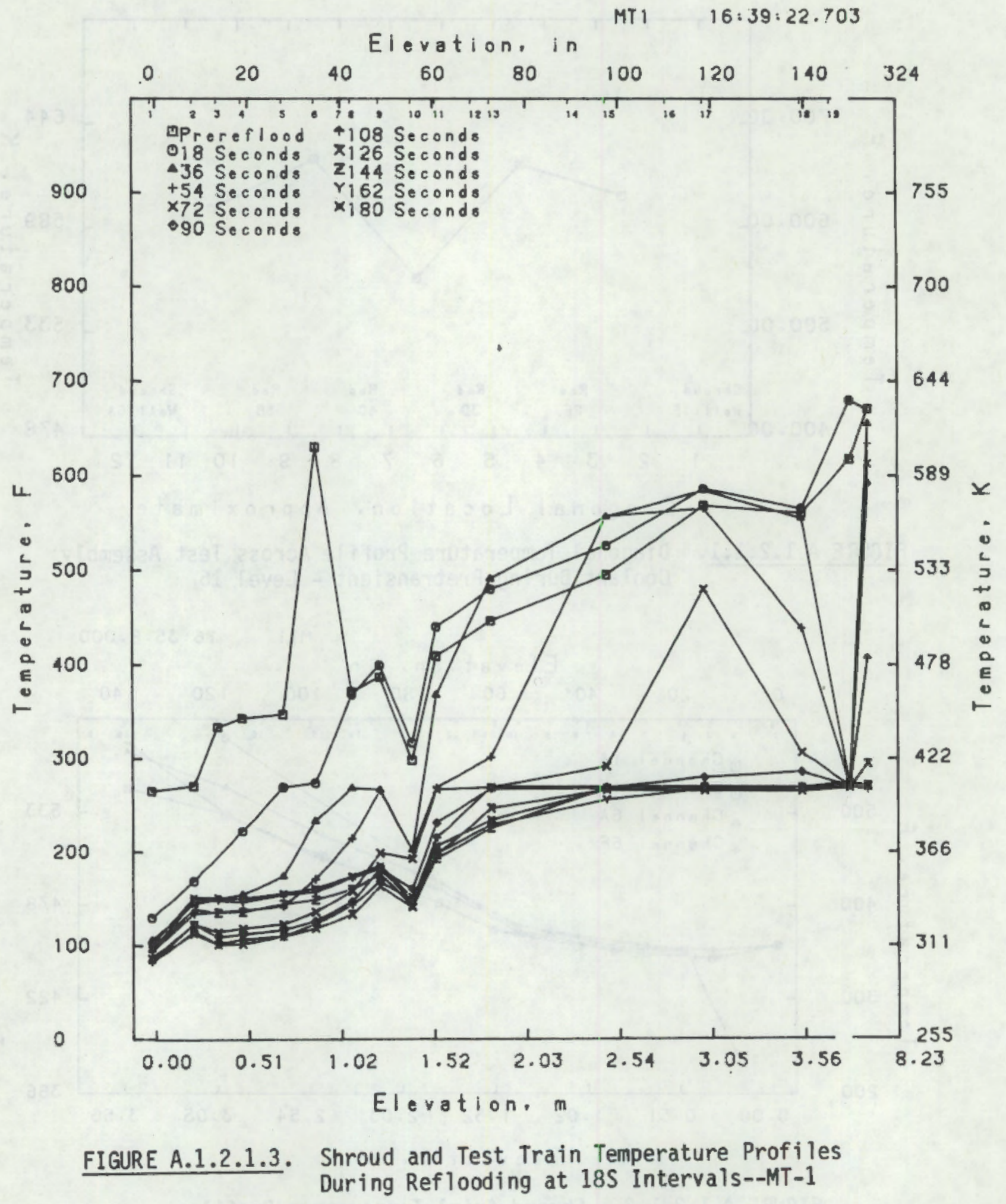




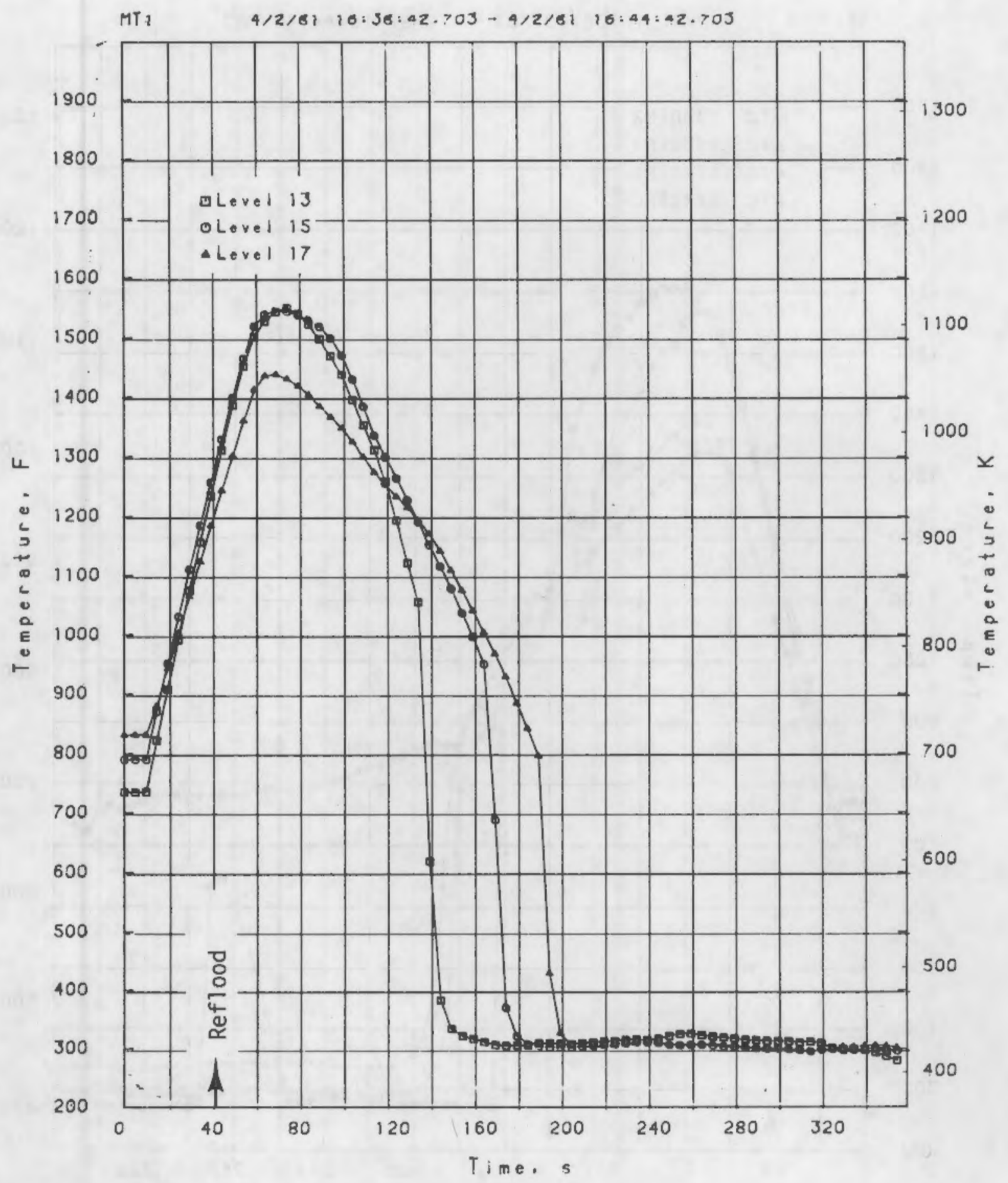

FIGURE A.1.2.2. Average Guard Fuel Rod $\mathrm{Cl}$ adding Temperature Histories (Interior TC's) During Transient MT-1 


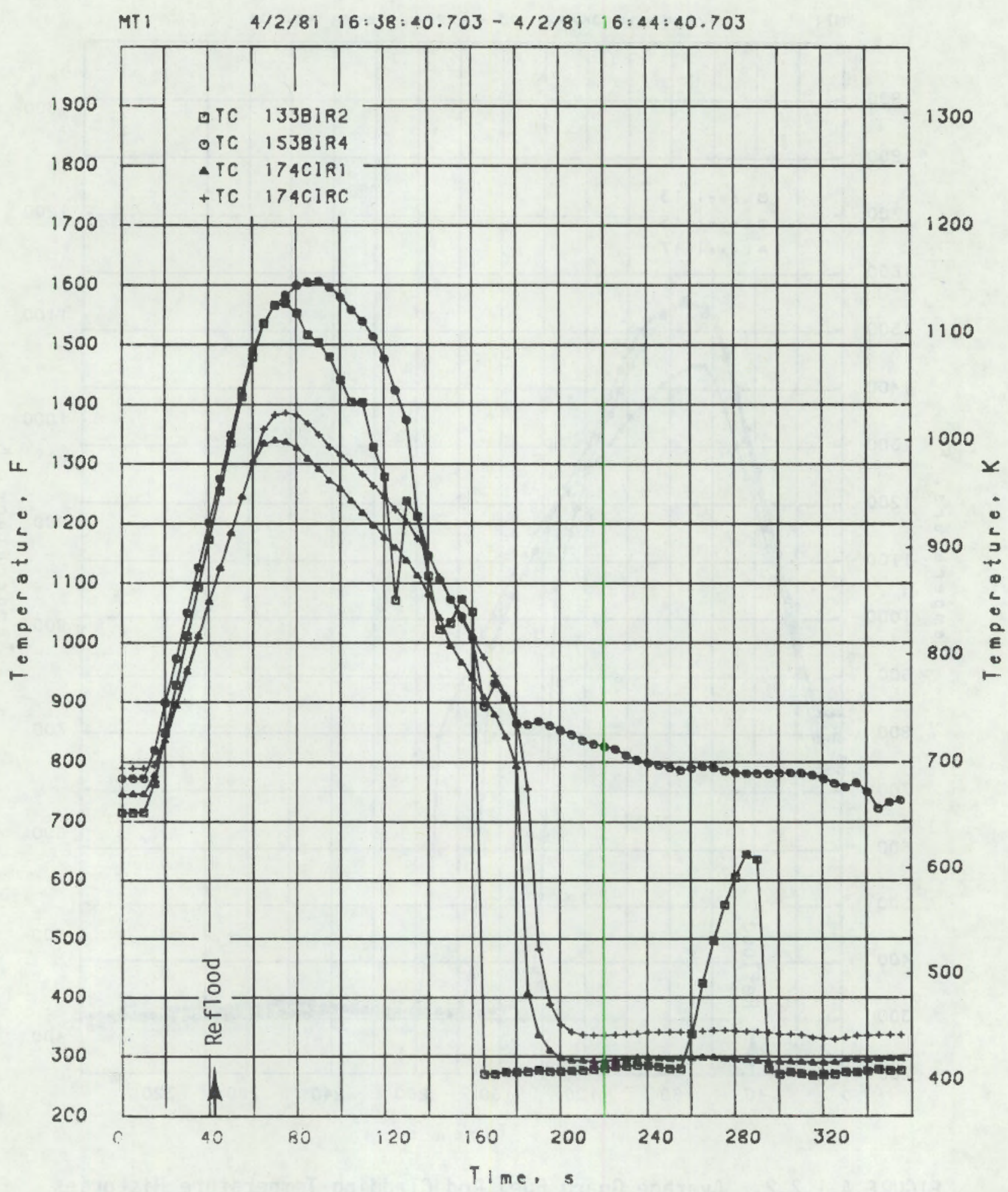

FIGURE A.1.2.3. Test Fuel Rod Center and Interior Cladding Temperature Histories During Transient MT-1 


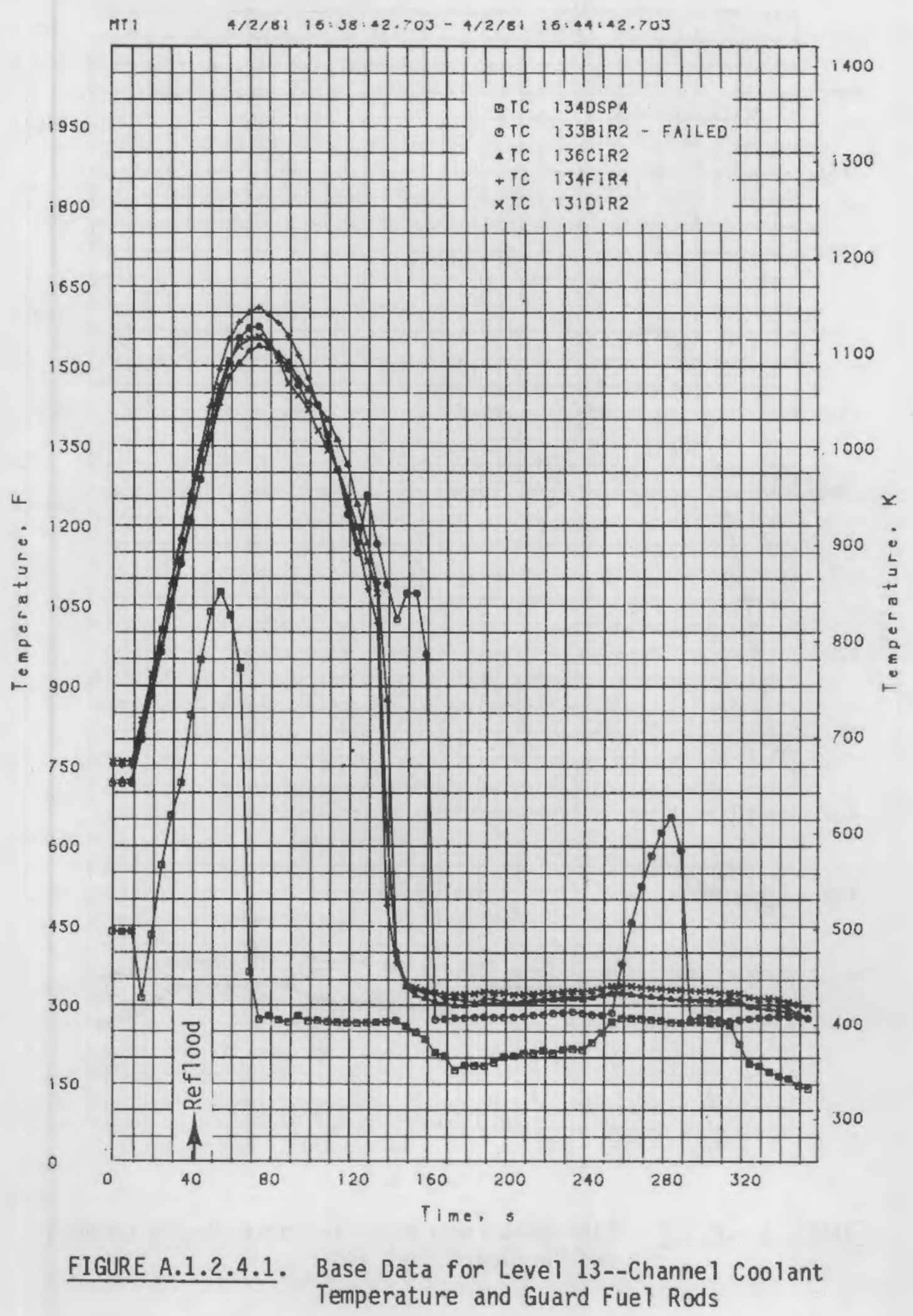

A. 9 


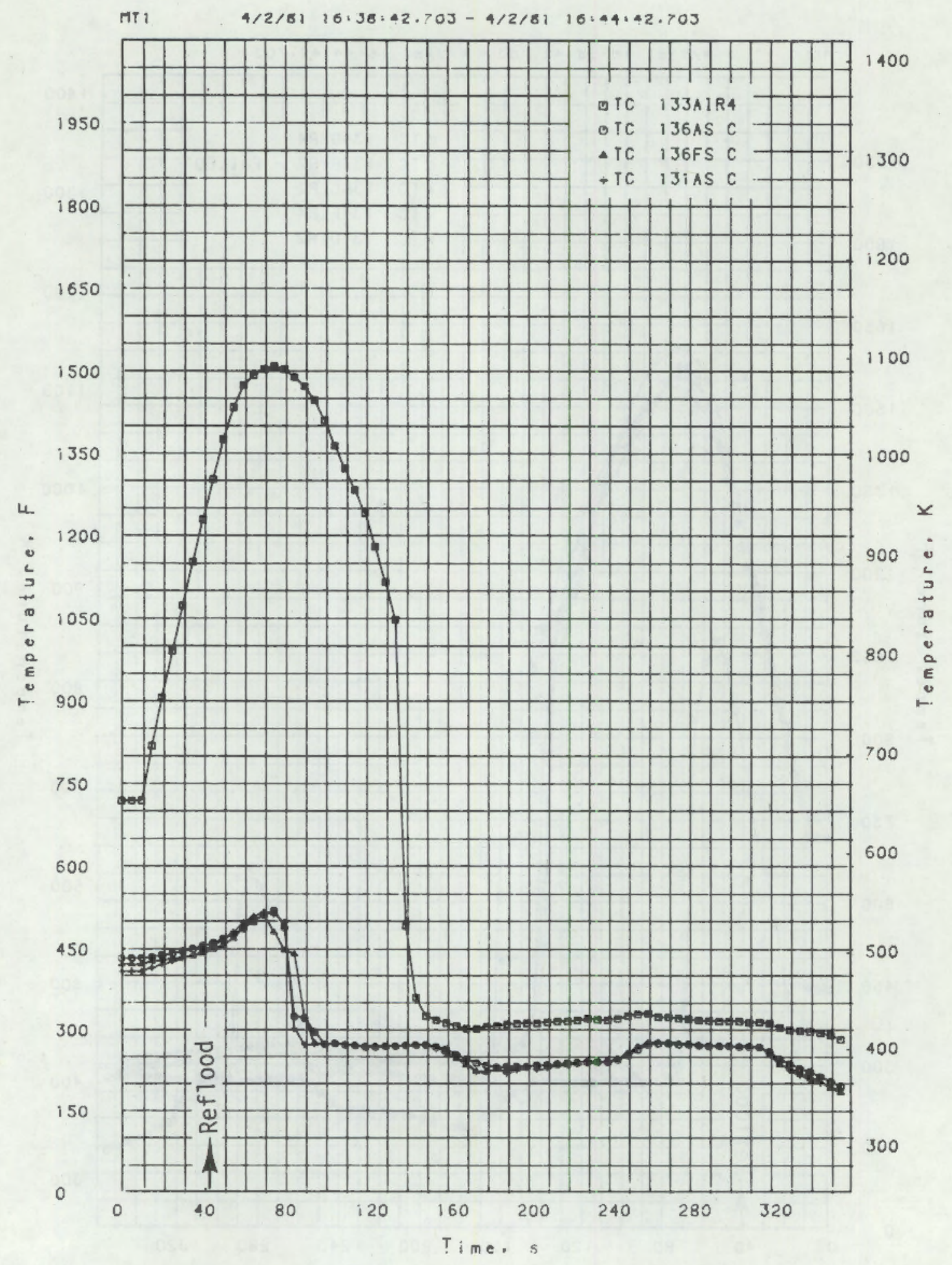

FIGURE A.1.2.4.2. Base Data for Level 13--Three Shroud Corners and One Guard Fuel Rod 


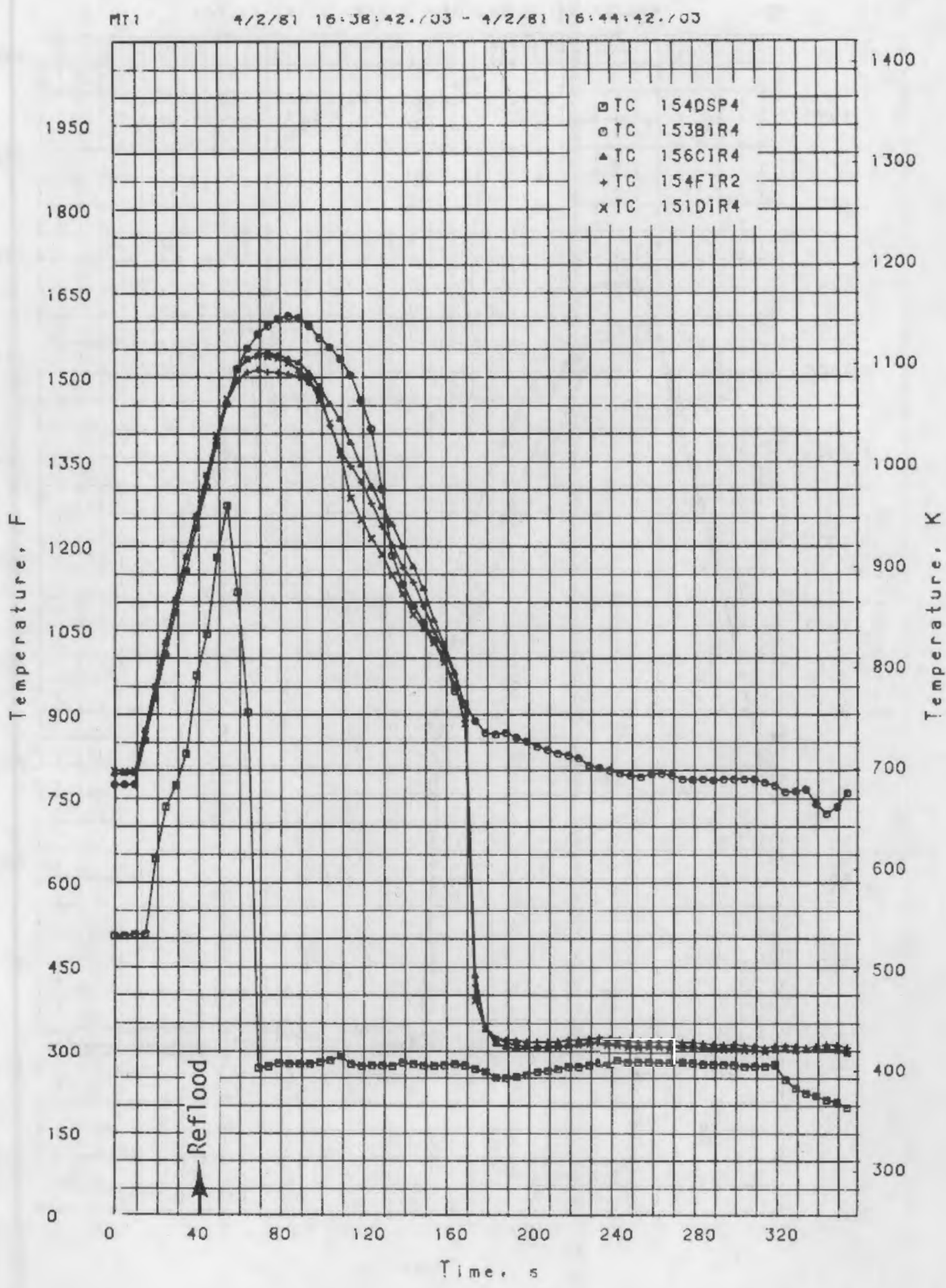

FIGURE A.1.2.4.3. Base Data for Level 15--One Channel Coolant Temperature, Three Guard Fuel Rods and One Test Fuel Rod 


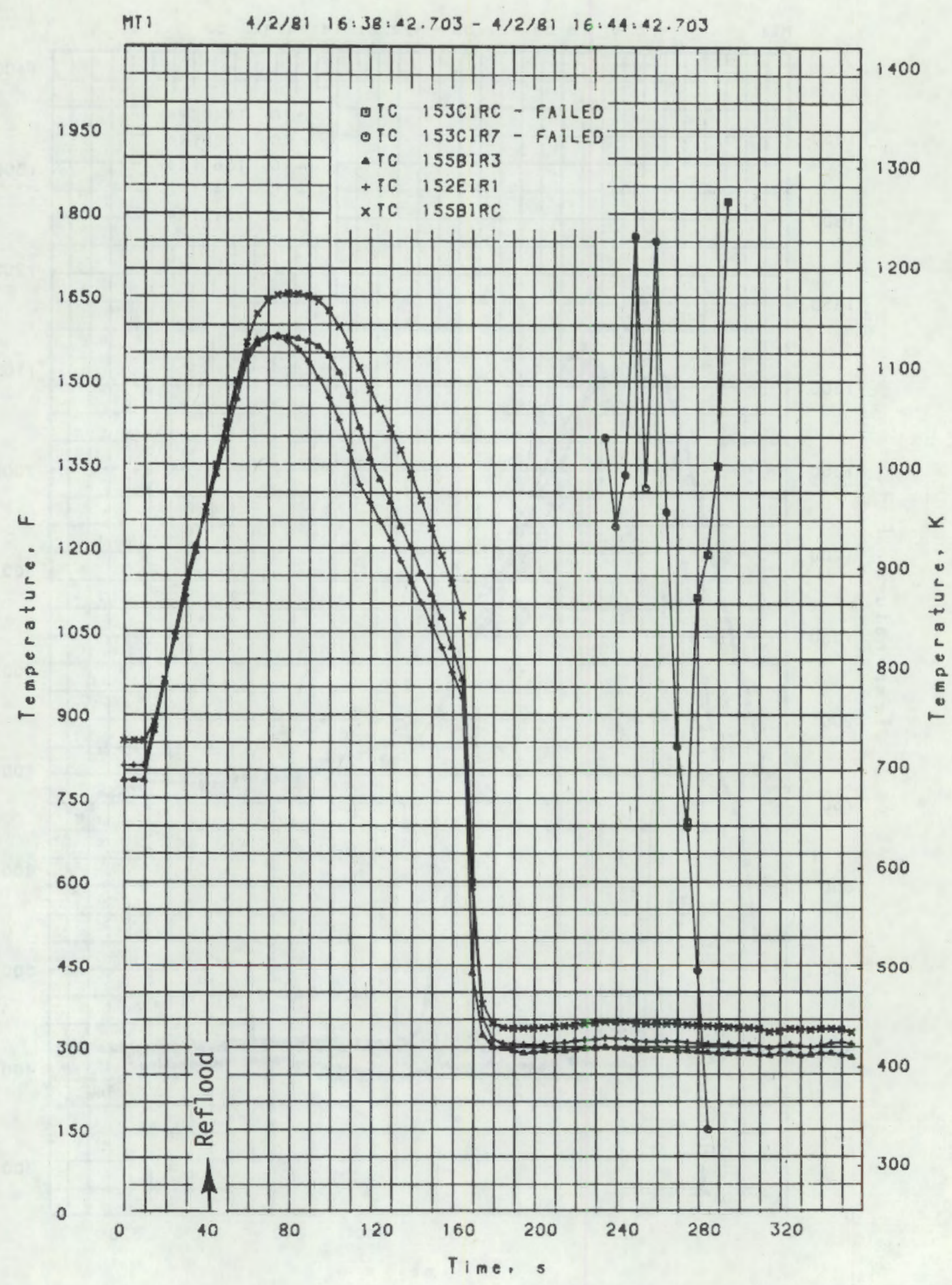

FIGURE A.1.2.4.4. Base Data for Level 15--Three Guard Fuel Rods, Cladding Inside and Fuel Centerline 


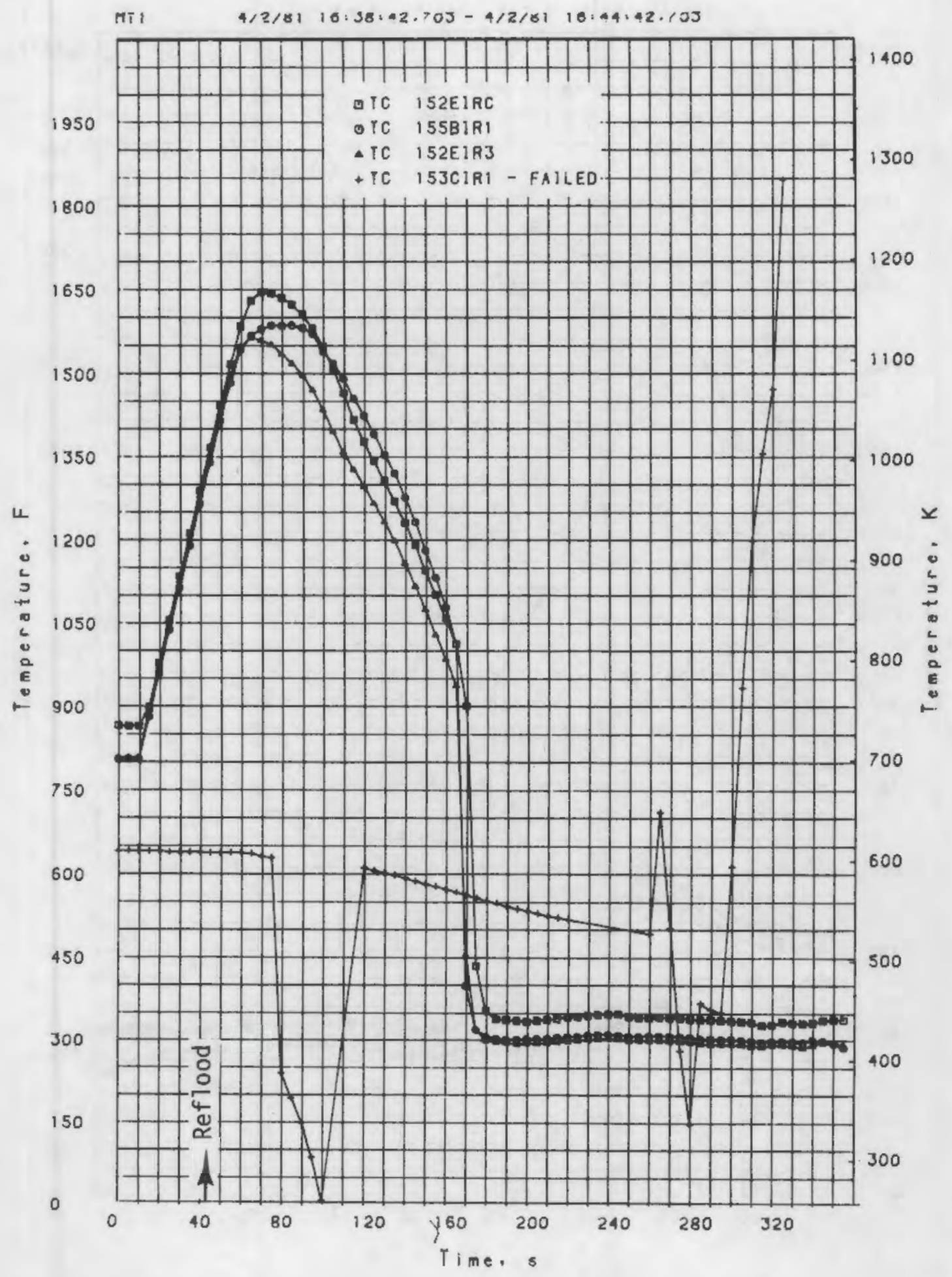

FIGURE A.1.2.4.5. Base Data for Level 15--Three Guard Fuel Rods, One Center line and Two $\mathrm{Cl}$ adding Inside 


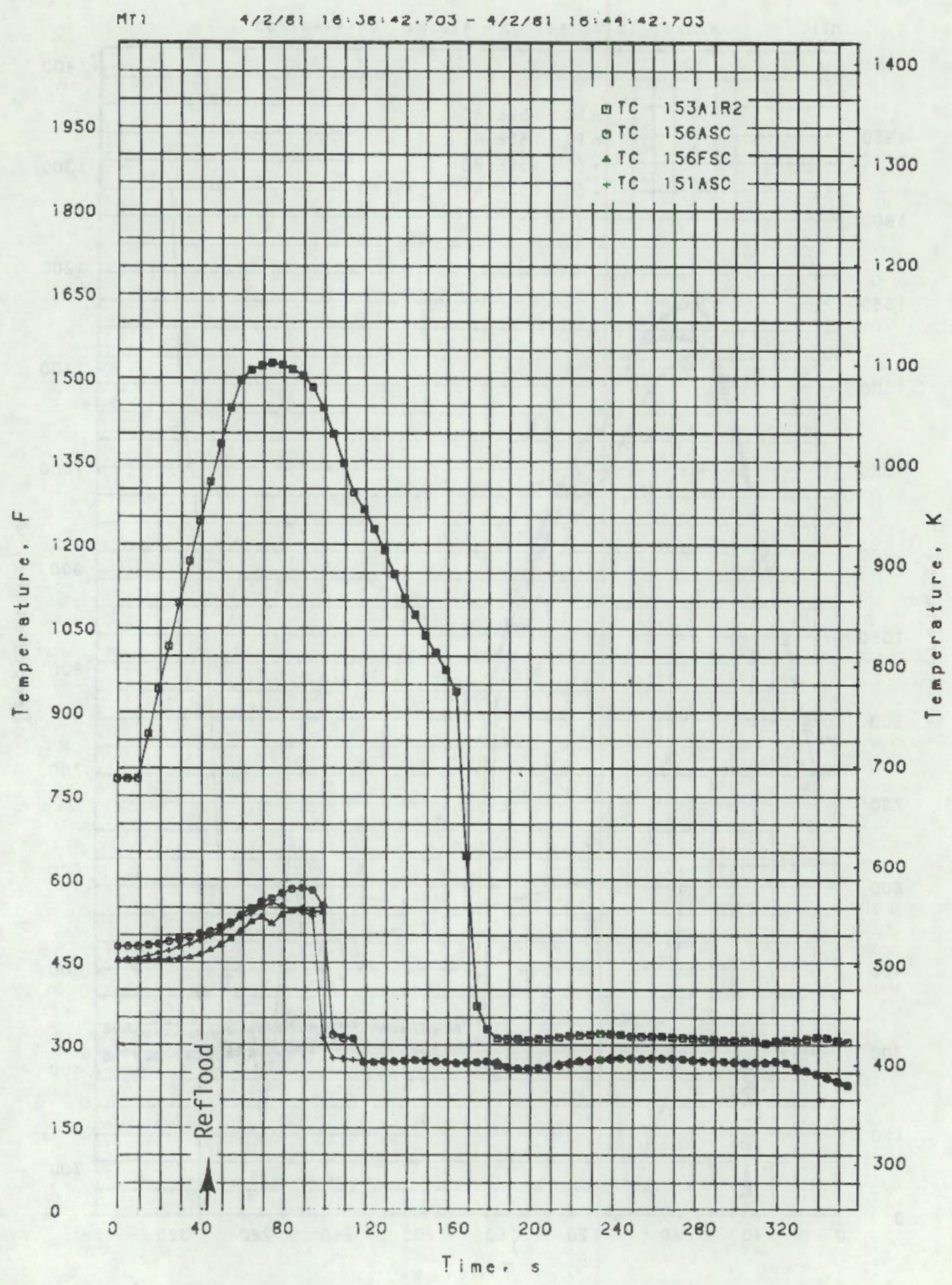

FIGURE A.1.2.4.6. Base Data for Level 15--One Guard Fuel Rod and Three Shroud Thermocouples 


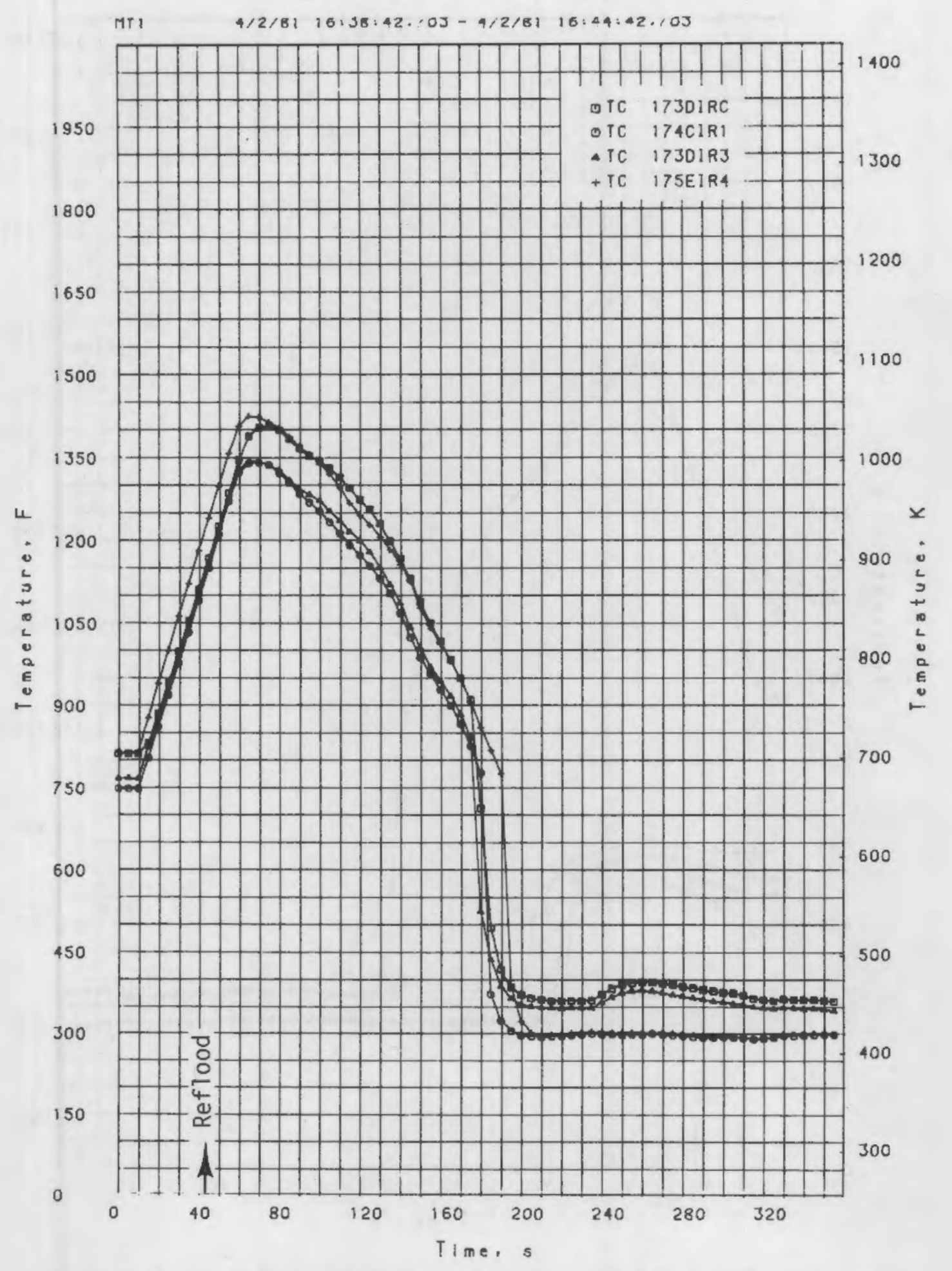

FIGURE A.1.2.4.7. Base Data for Level 17--Three Test Fuel Rods and One Guard Fuel Rod 


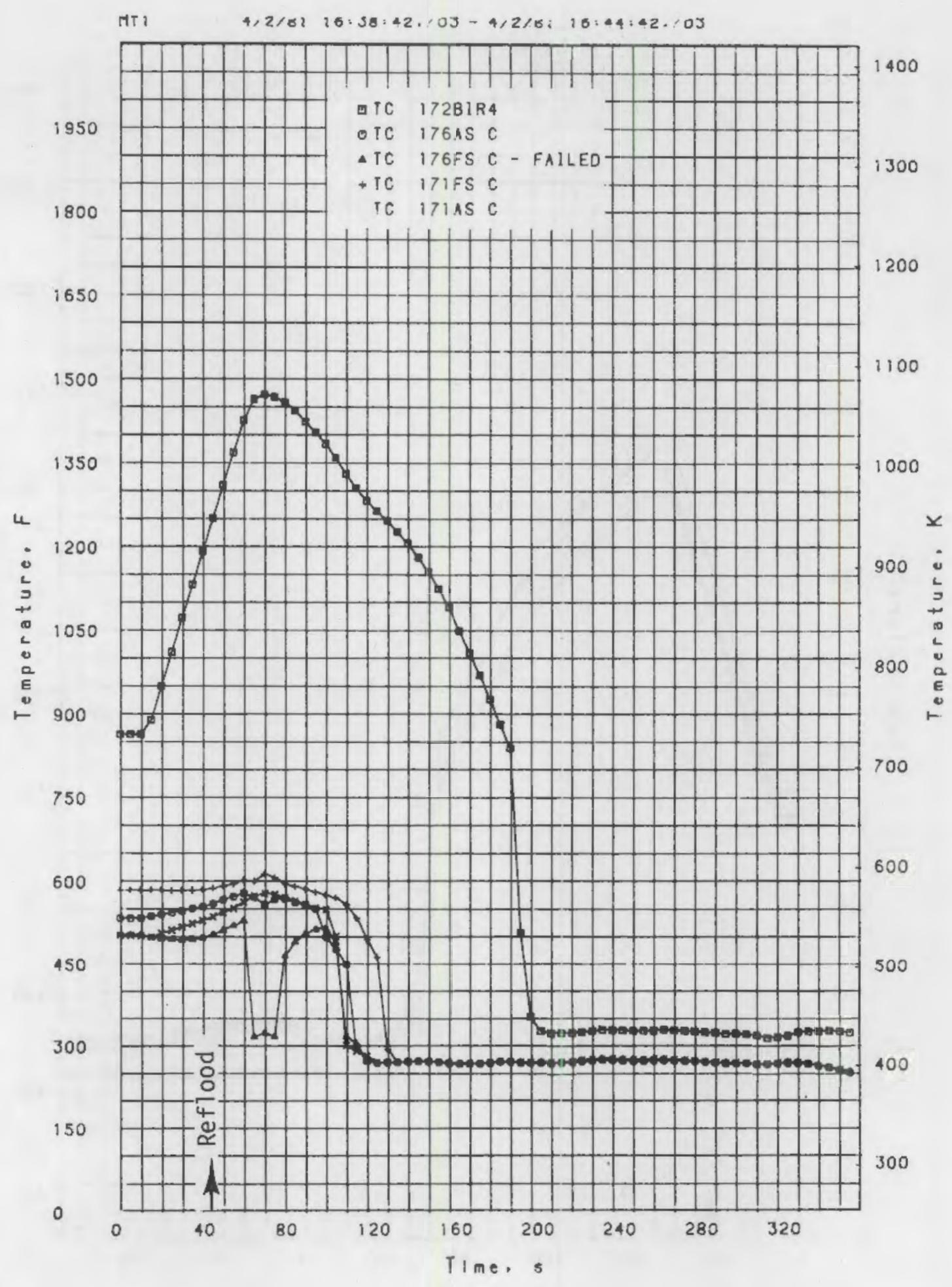

FIGURE A.1.2.4.8. Base Data for Level 17--One Guard Fuel Rod and Three Shroud Corners 


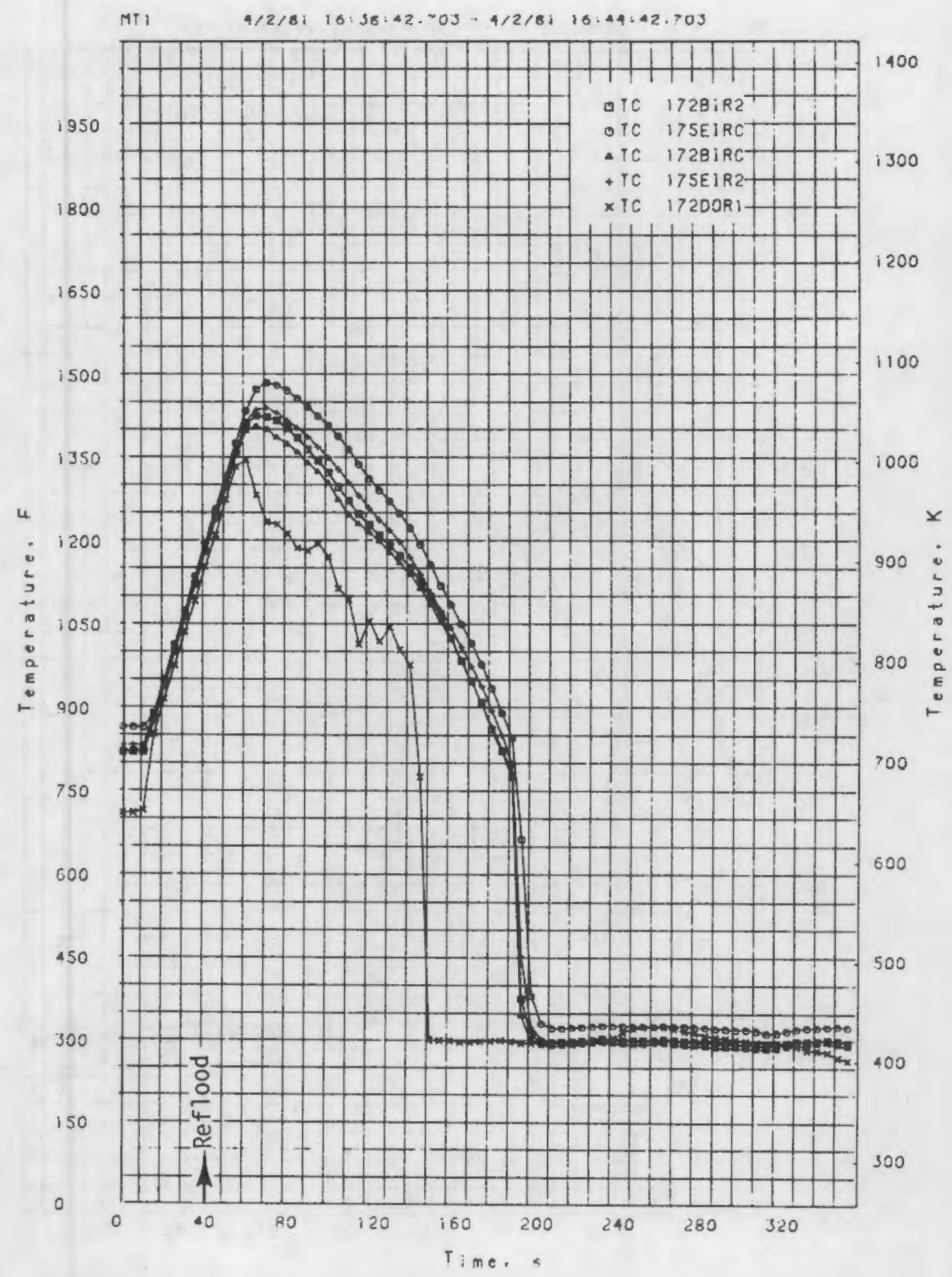

FIGURE A.1.2.4.9. Base Data for Level 17--Two Test Fuel Rods, Cladding Inside and One Fuel Rod, Cladding Outside 


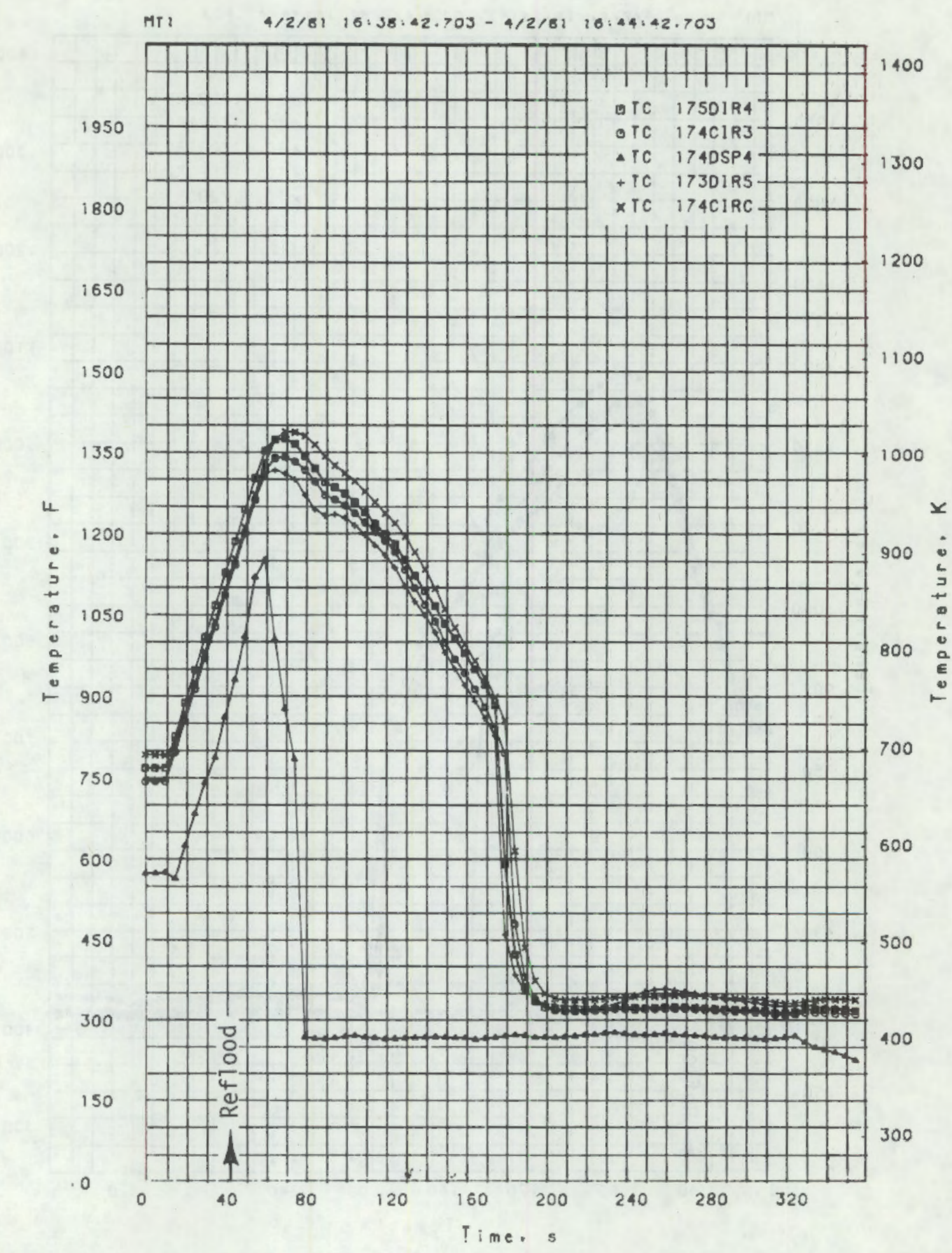

FIGURE A.1.2.4.10. Base Data for Level 17--Three Test Fuel Rods, Cladding Inside and Fuel Centerline, One Cool ant Channel 


\section{SECTION 2}

NEUTRON FLUX DATA 


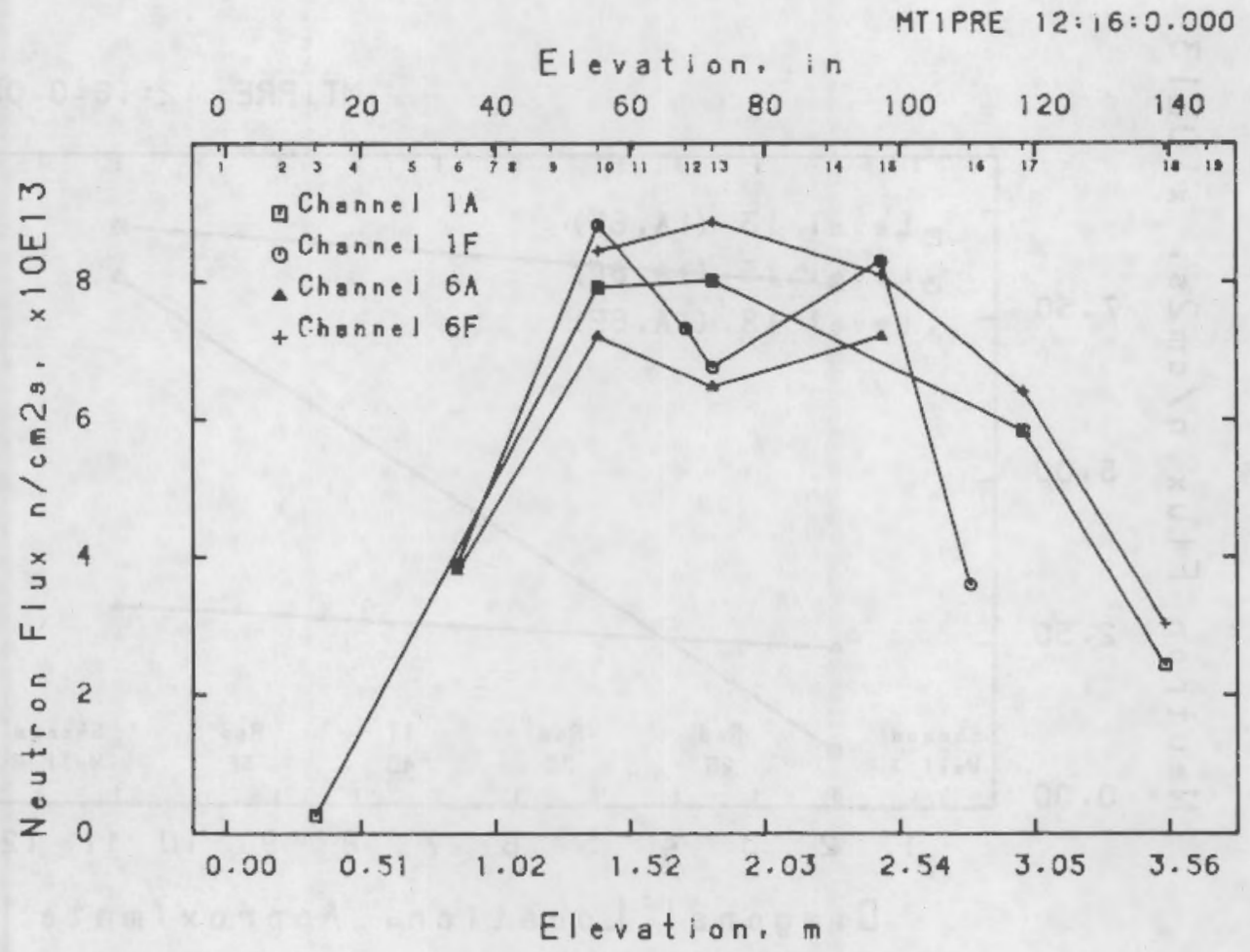

FIGURE A.2.1.1. Preconditioning (Shroud) Neutron Flux Axial Profiles 


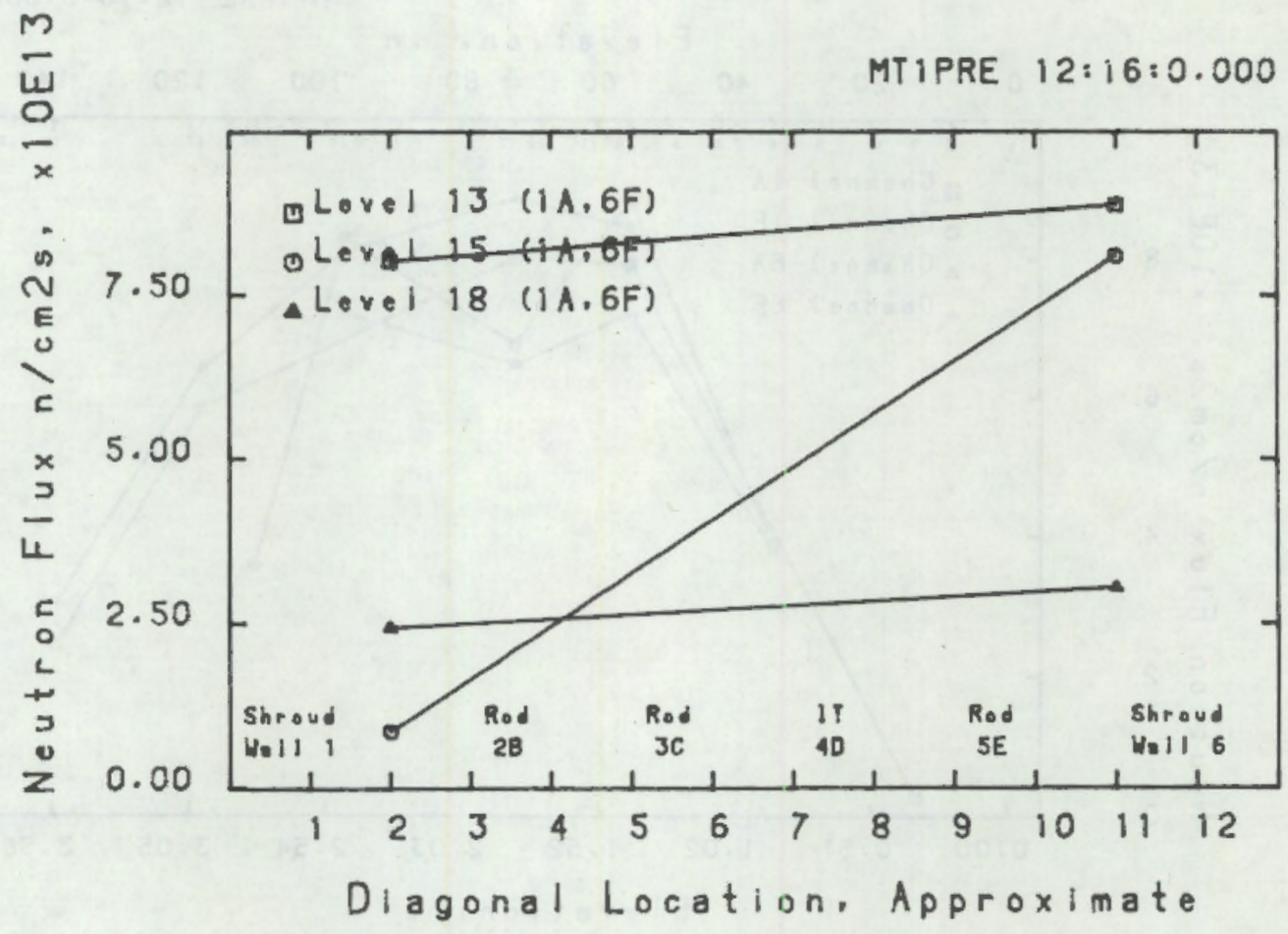

FIGURE A.2.1.2. Diagonal Neutron Flux Profile Across Test Assembly--Preconditioning 


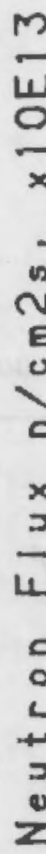

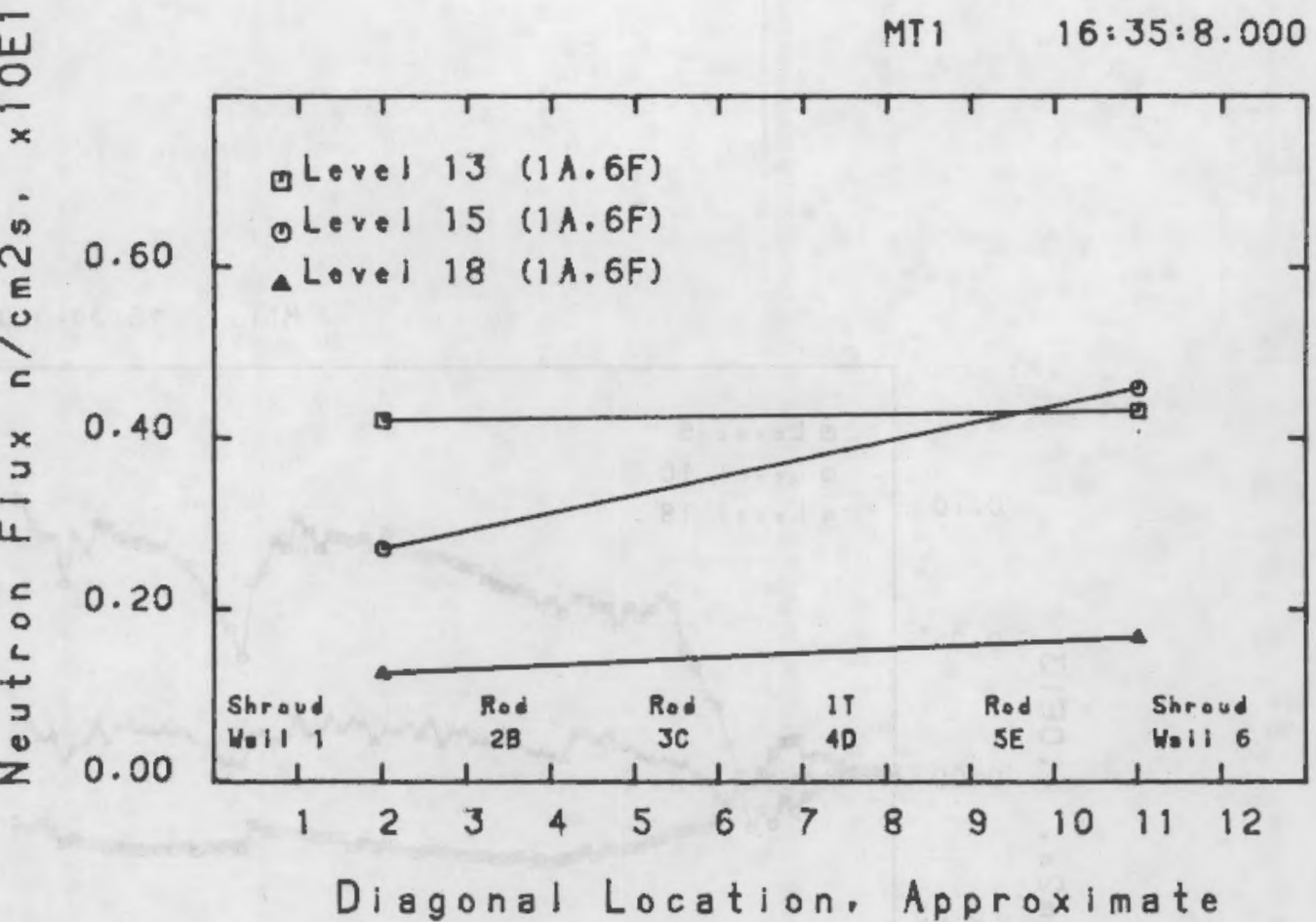

FIGURE A.2.2.1. Diagonal Neutron Flux Profile Across the Test Assembly--Pretransient MT-1

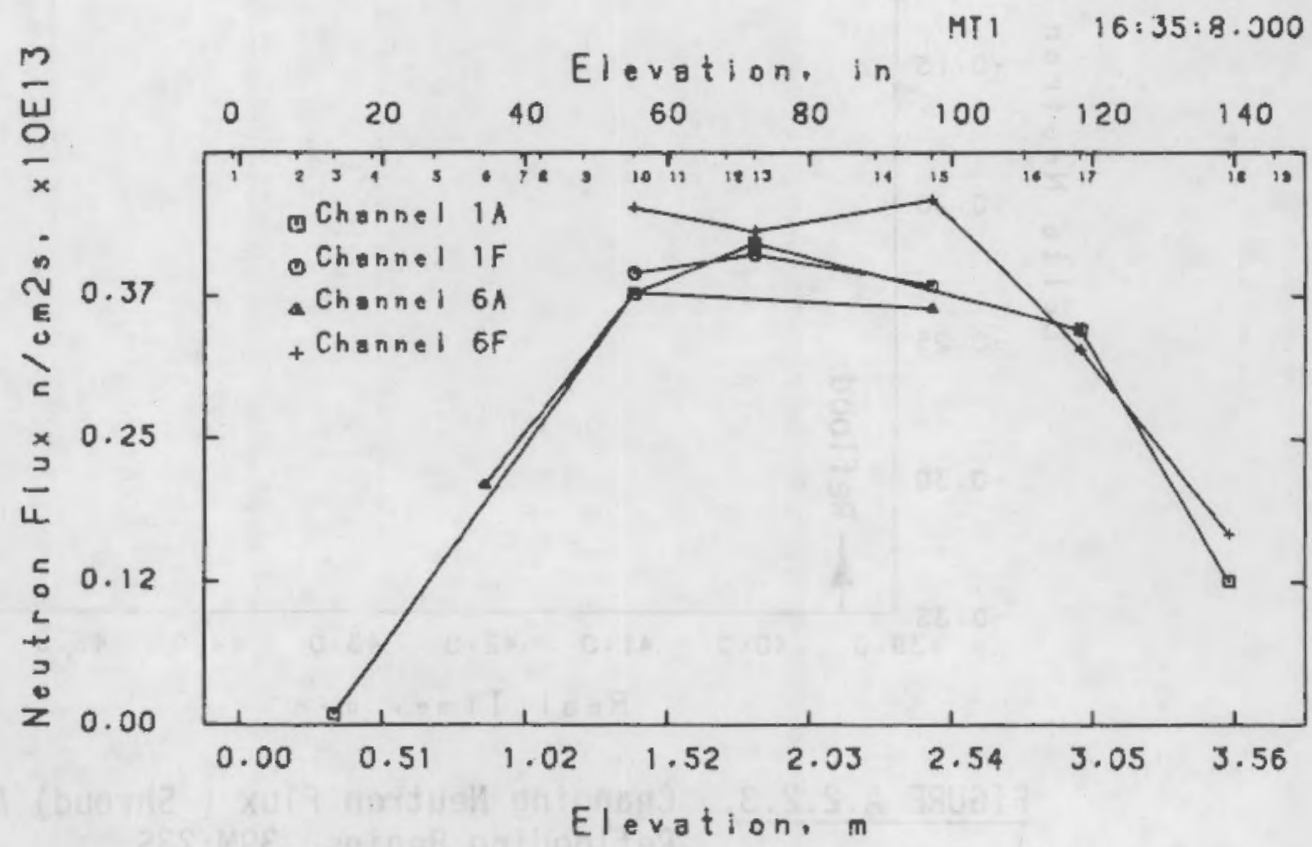

FIGURE A.2.2.2. Axial Neutron Flux Profile in the Shroud-Pretransient MT-1 


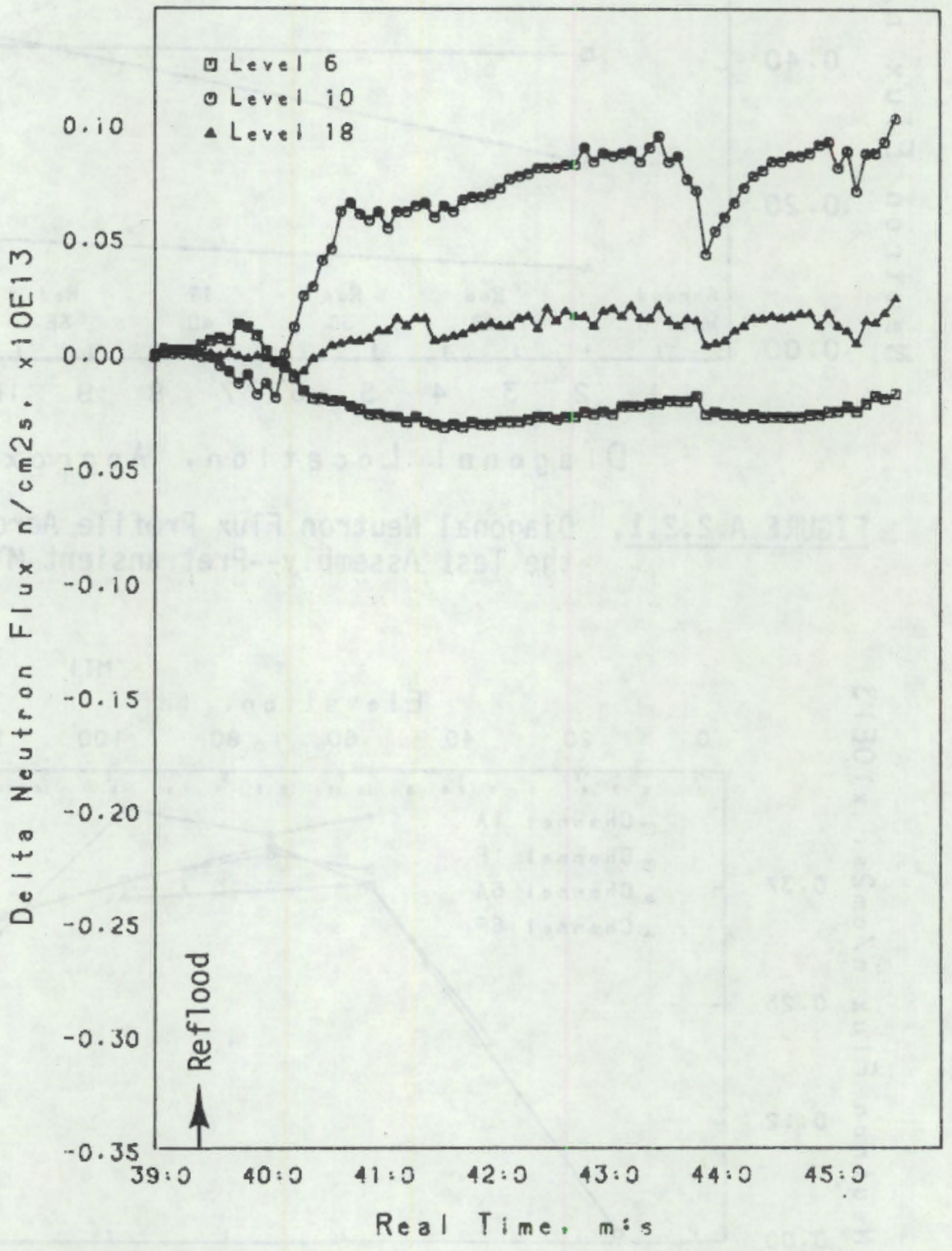

FIGURE A.2.2.3. Changing Neutron Flux (Shroud) After Reflooding Begins, 39M:23S 
SECTION 3

STEAM PROBE TEMPERATURE DATA 


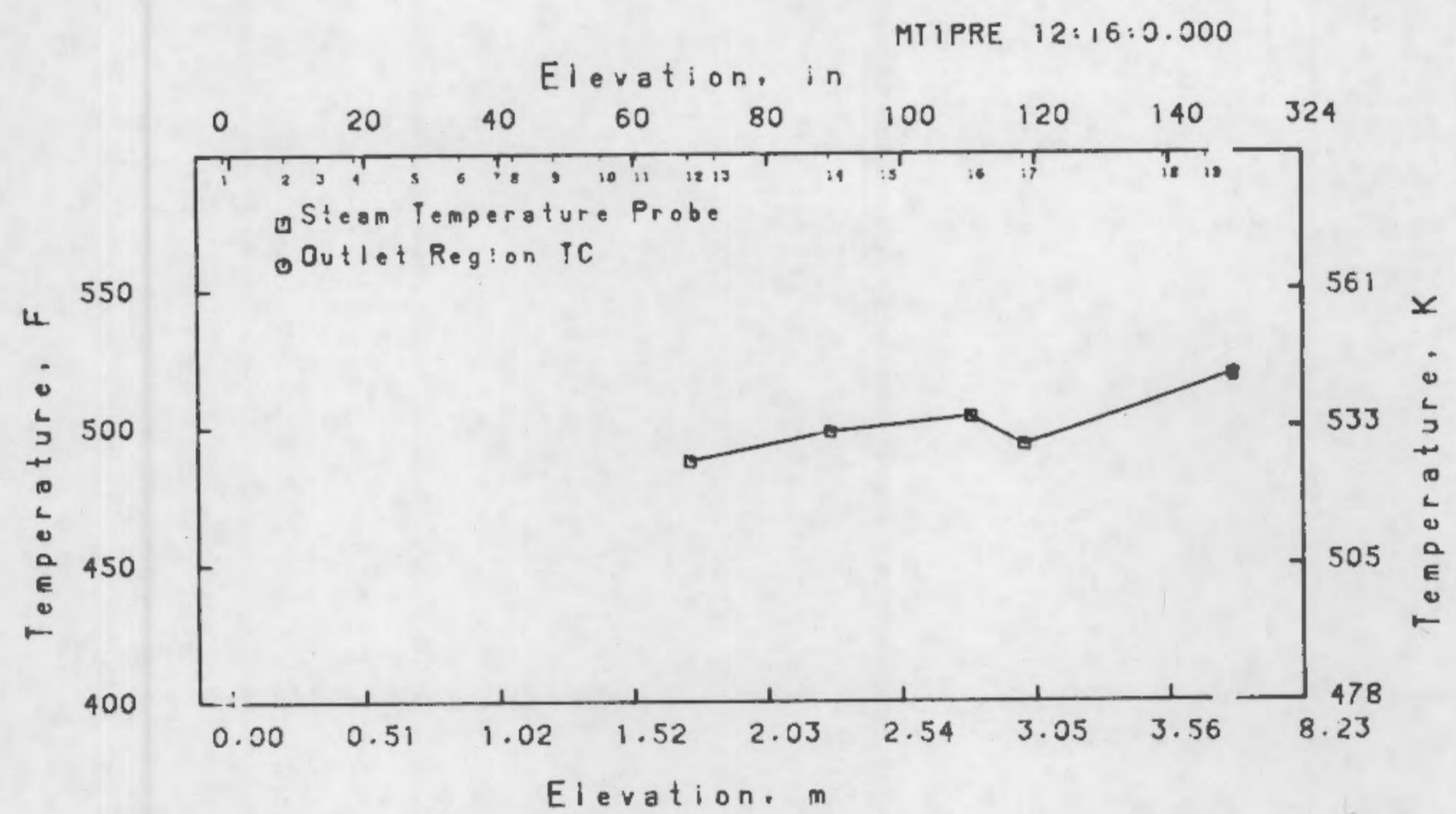

\section{FIGURE A.3.1.1. Average Steam Probe Temperature Profile} (in Water During Preconditioning)

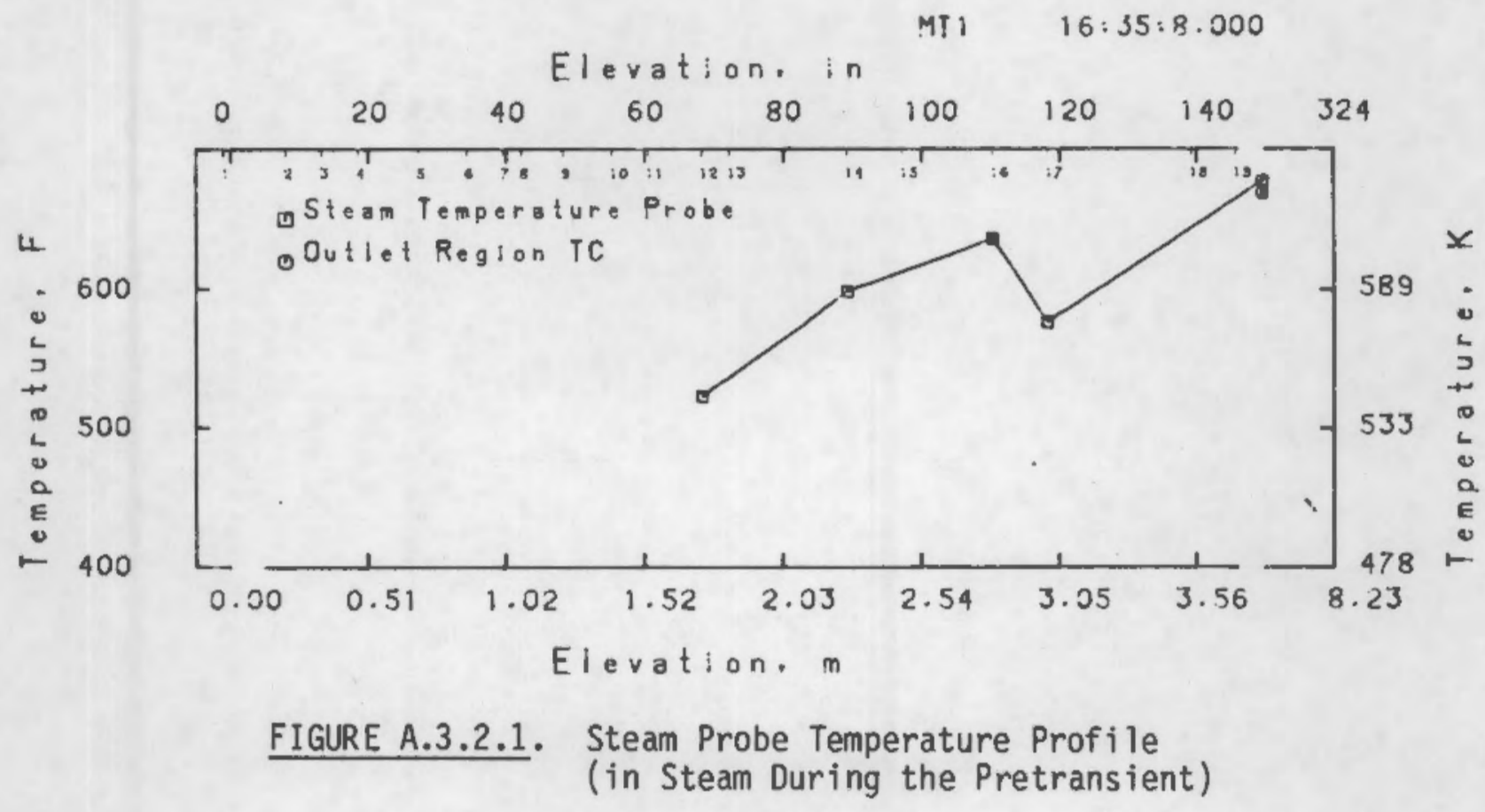



SECTION 4

FLOW TEST REFLOOD DATA 


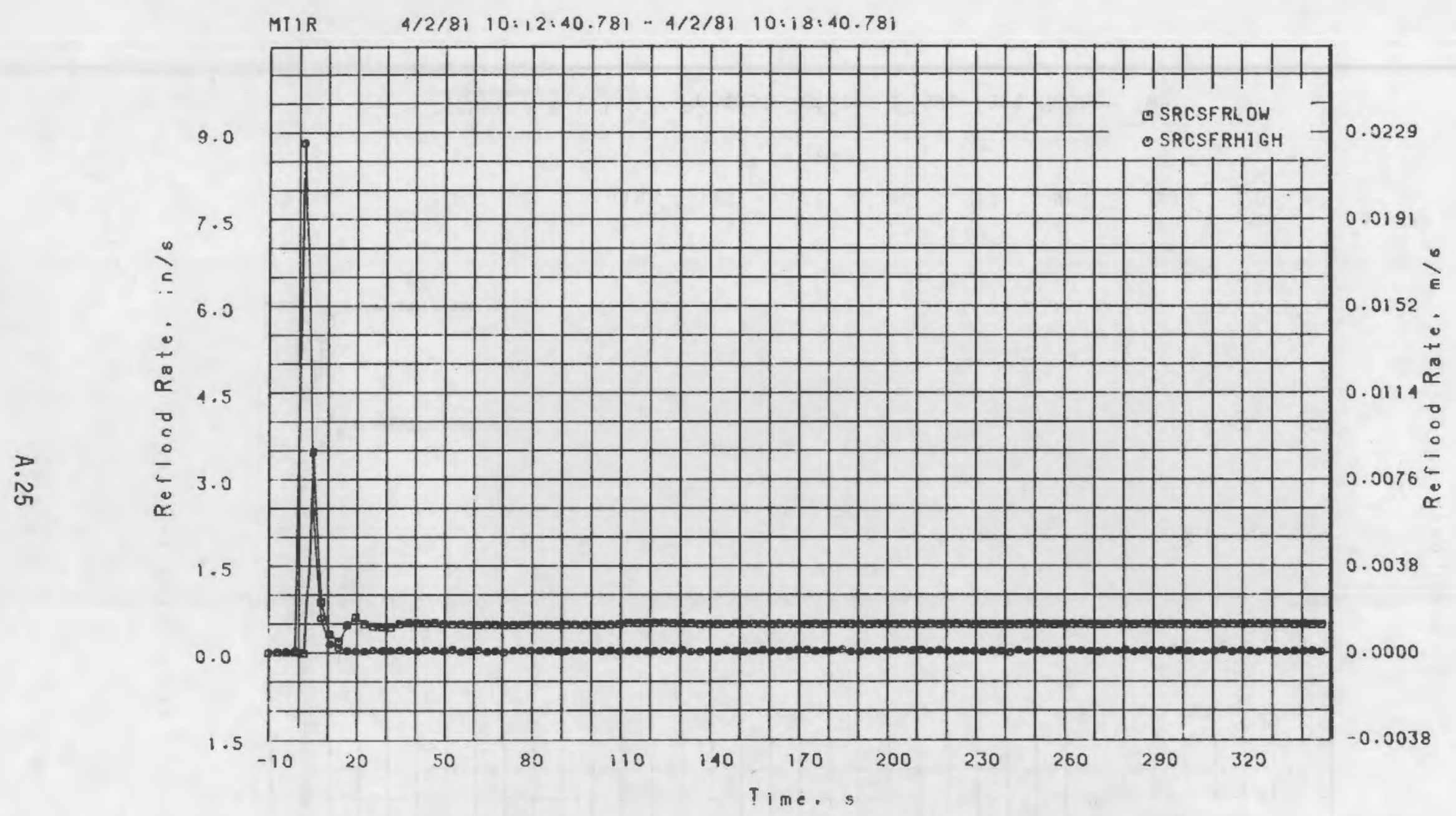

FIGURE A.4.1.1.1. Pretest Reflood Flow, Test Number One 


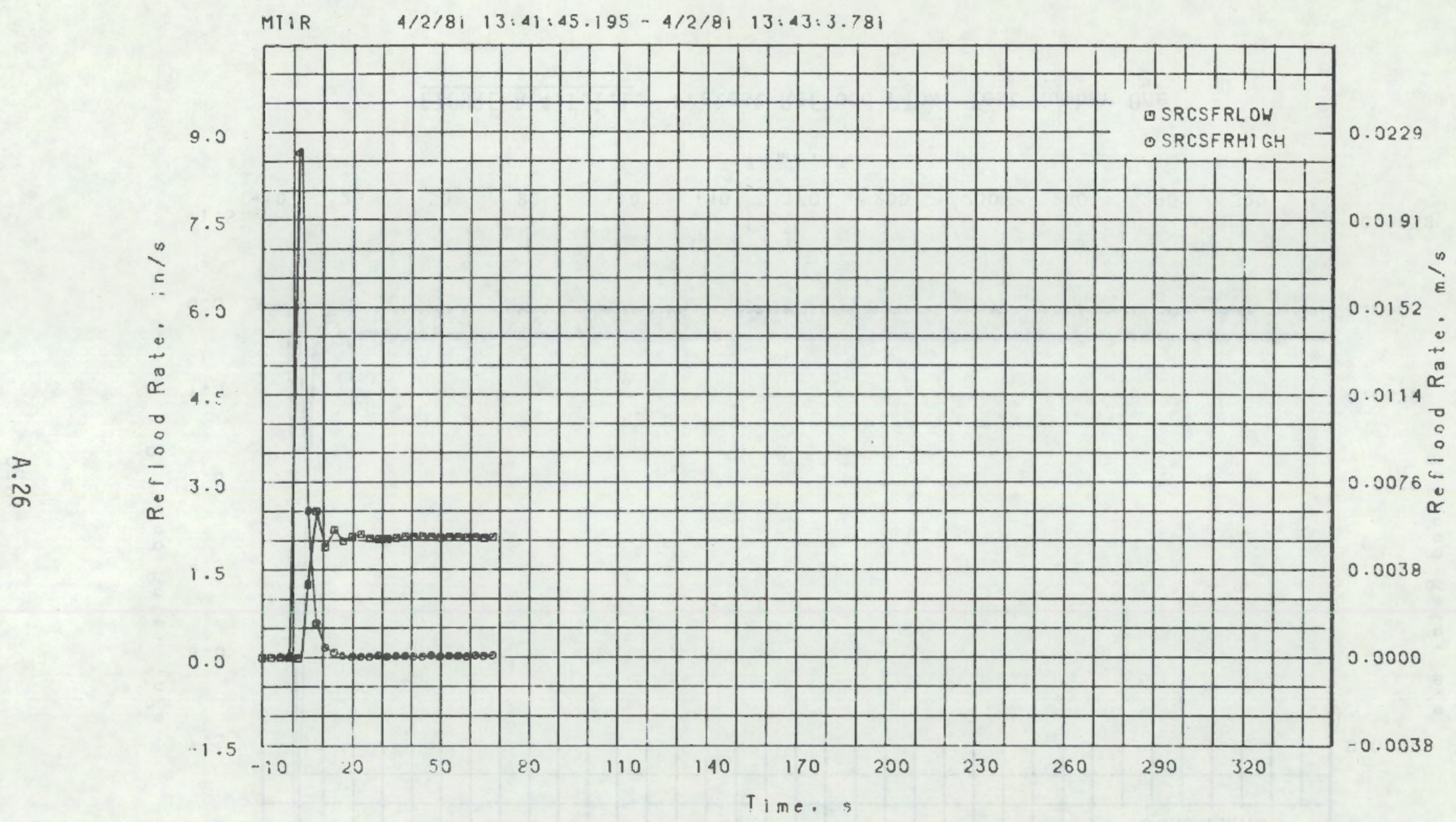

FIGURE A.4.1.1.2. Pretest Reflood Flow, Test Number Two 


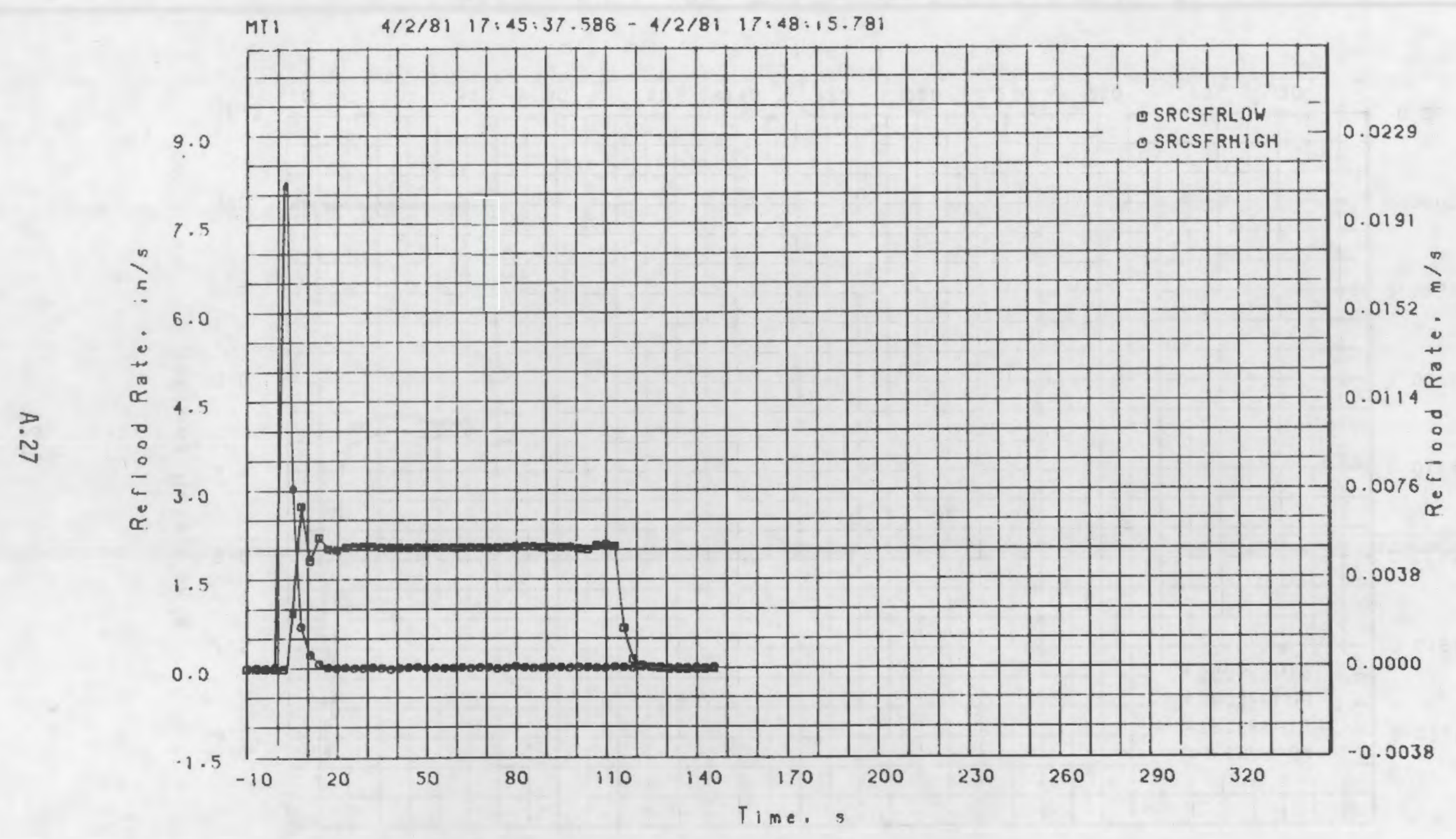

FIGURE A.4.1.1.3. Post-Test Reflood Flow, Test Number One 


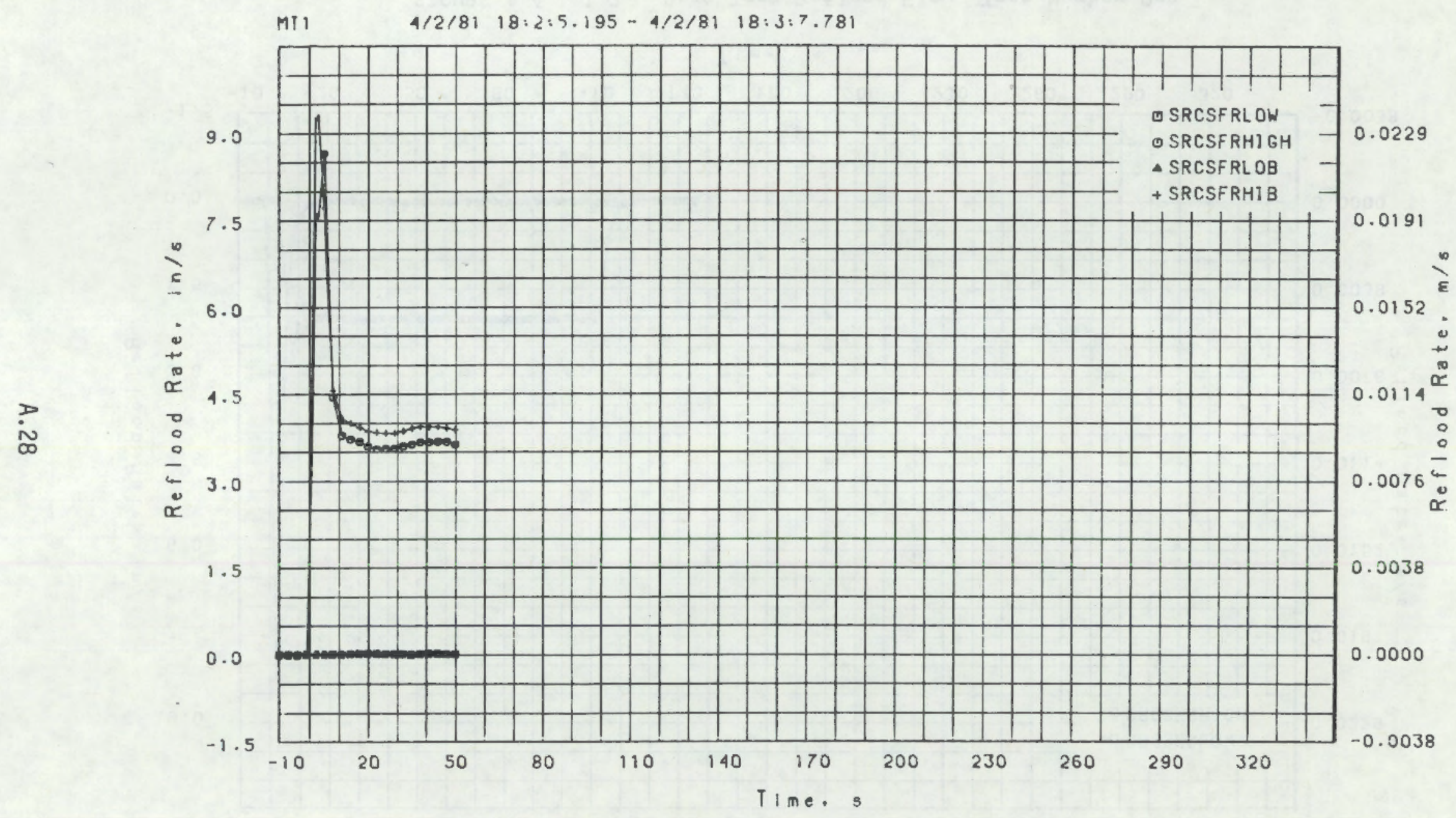

FIGURE A.4.1.1.4. Post-Test Reflood Flow, Test Number Two 


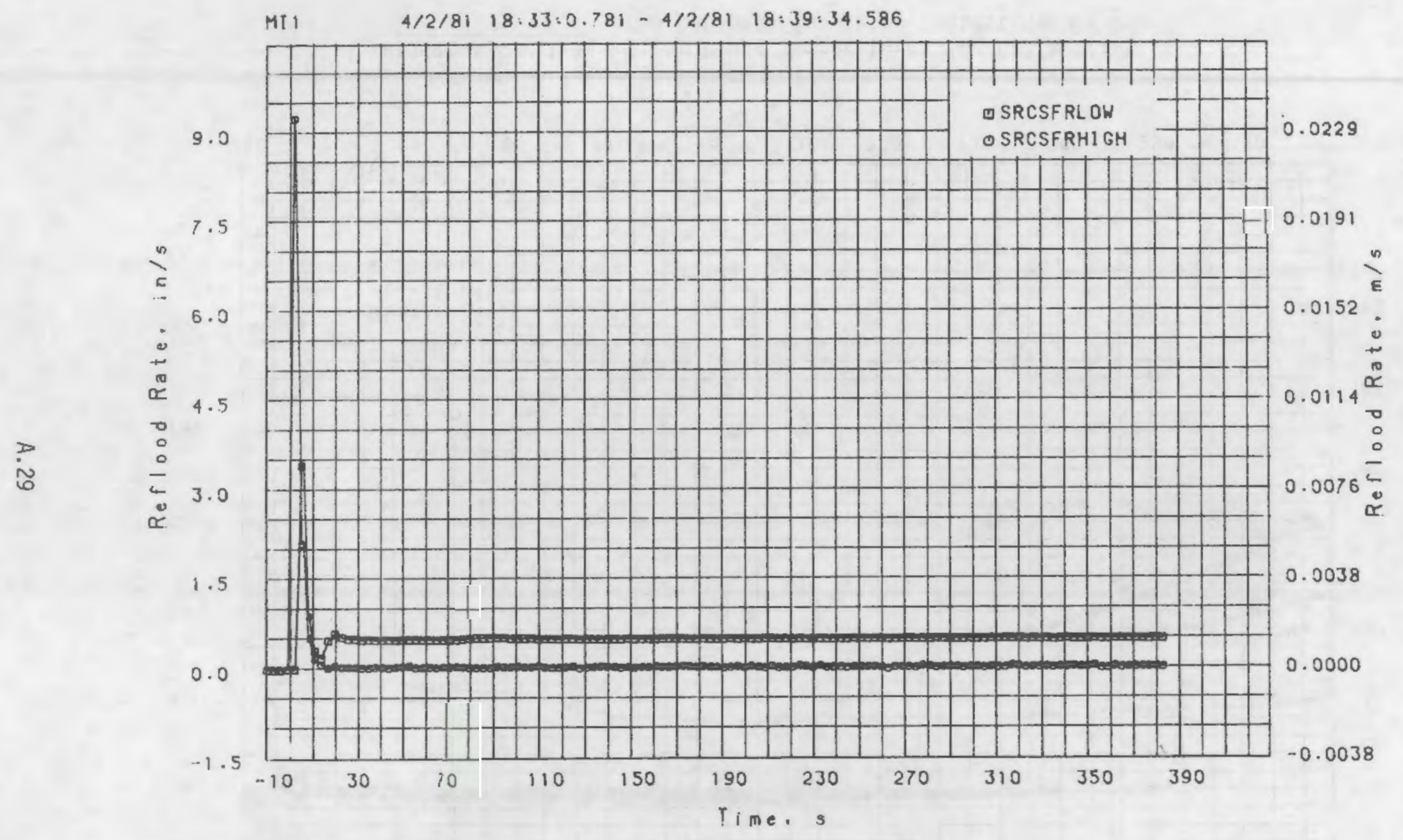

FIGURE A.4.1.1.5. Post-Test Reflood, Test Number Three 


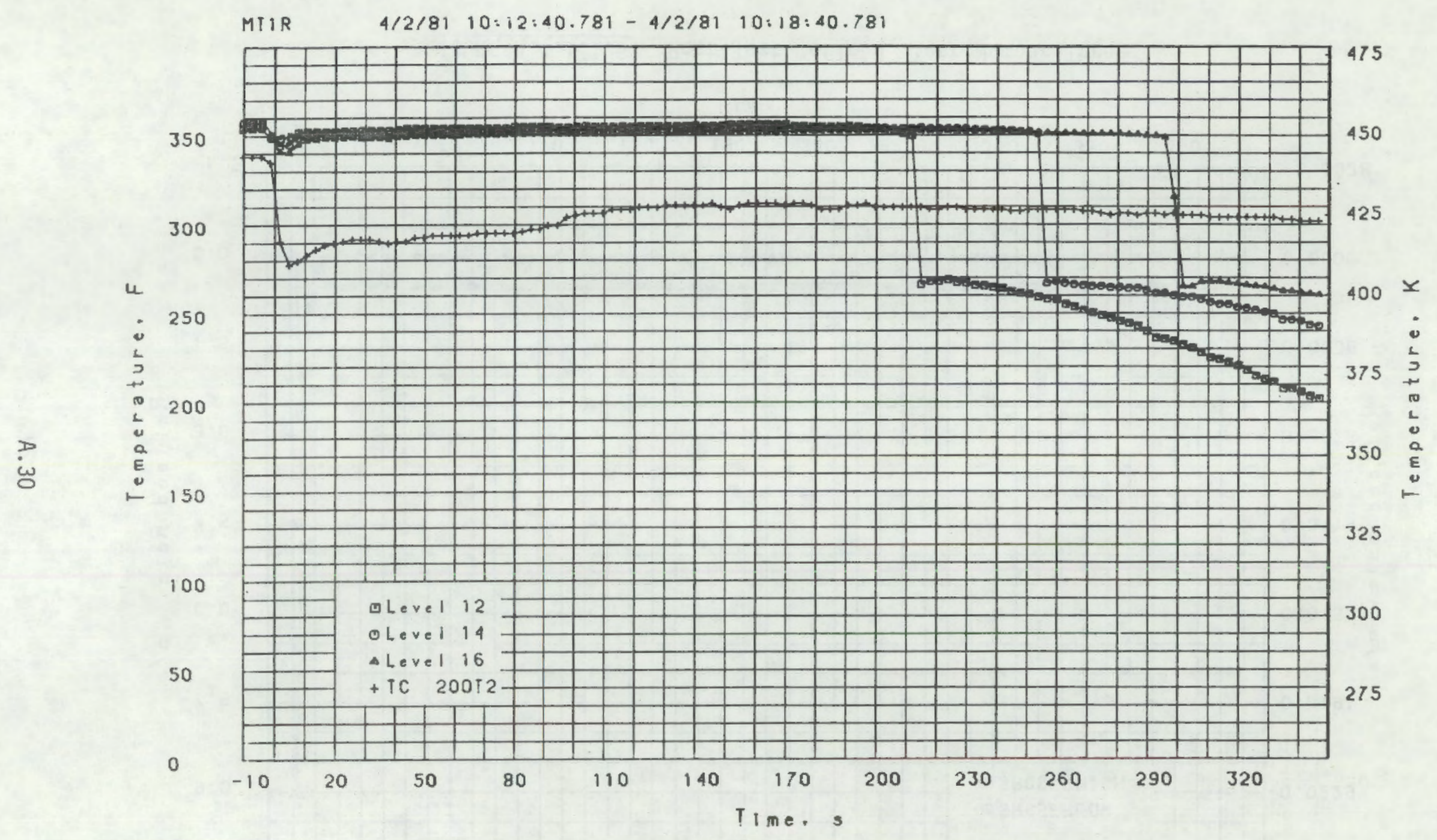

FIGURE A.4.2.1.1. Steam Probe Temperatures for Calibrating the Reflood Flow Rate, Pretest Number One 


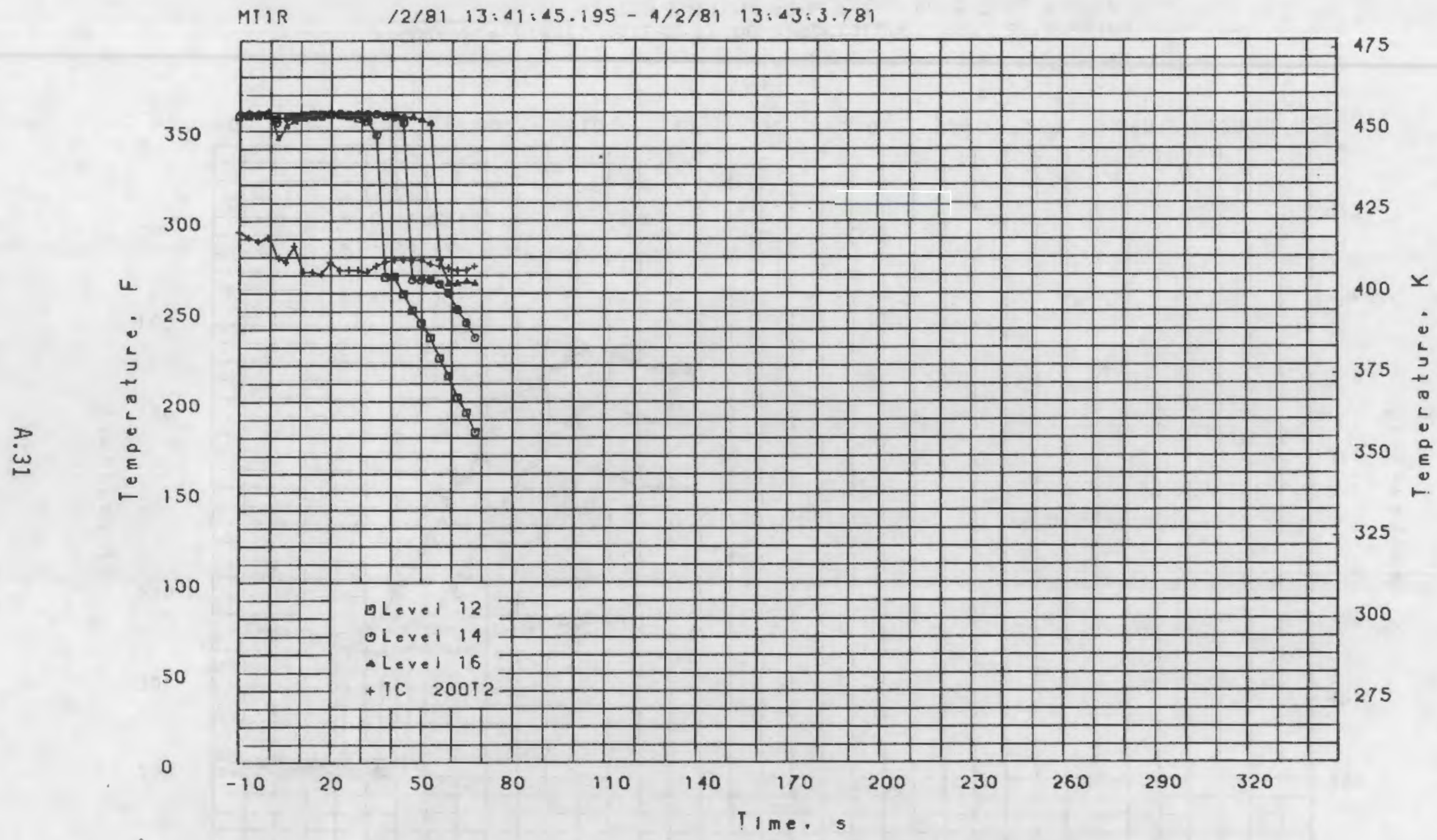

FIGURE A.4.2.1.2. Steam Probe Temperatures for Calibrating the Reflood Flow Rate, Pretest Number Two 


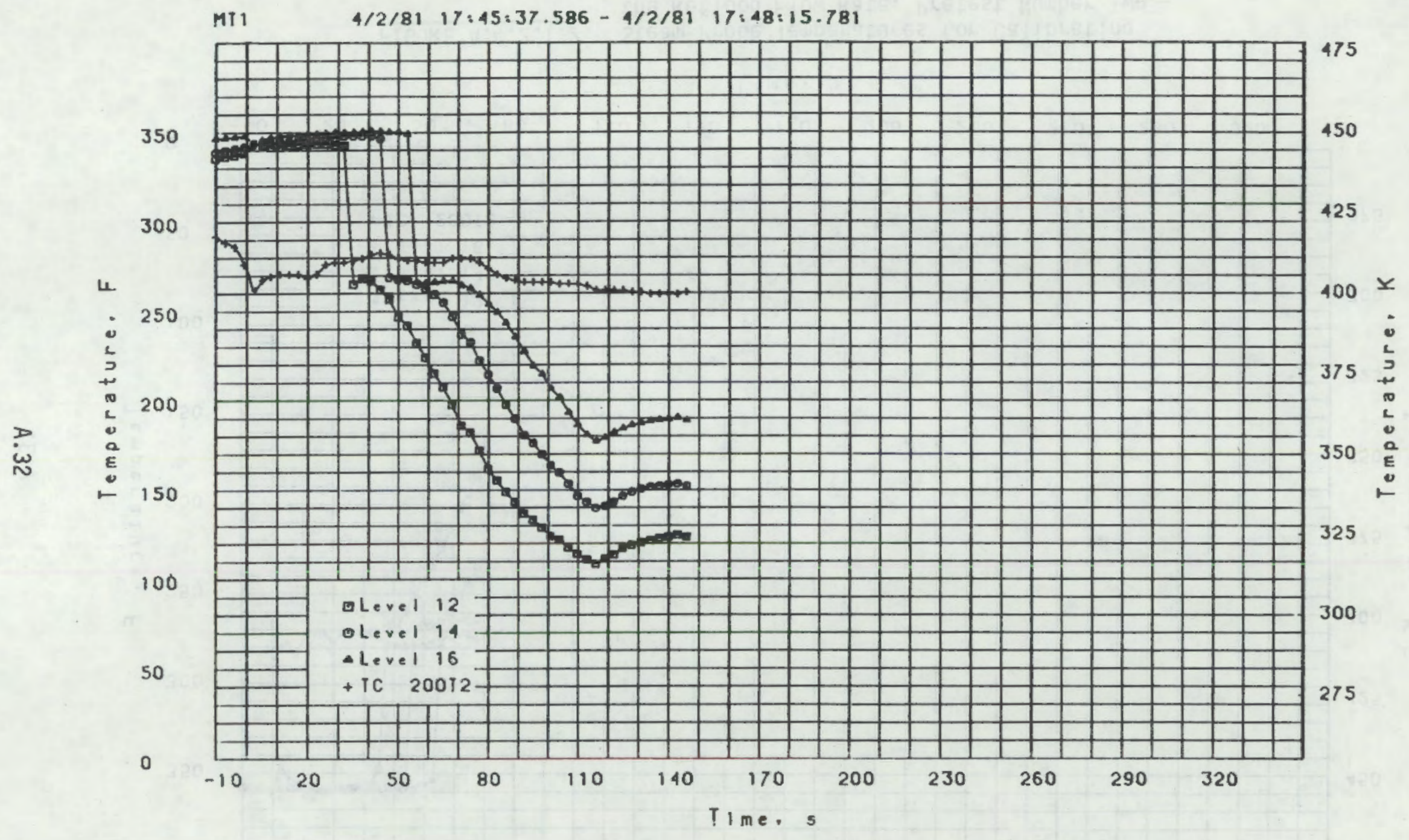

FIGURE A.4.2.2.1. Steam Probe Temperatures for Calibrating the Reflood Flow Rate, Post-Test Number One 


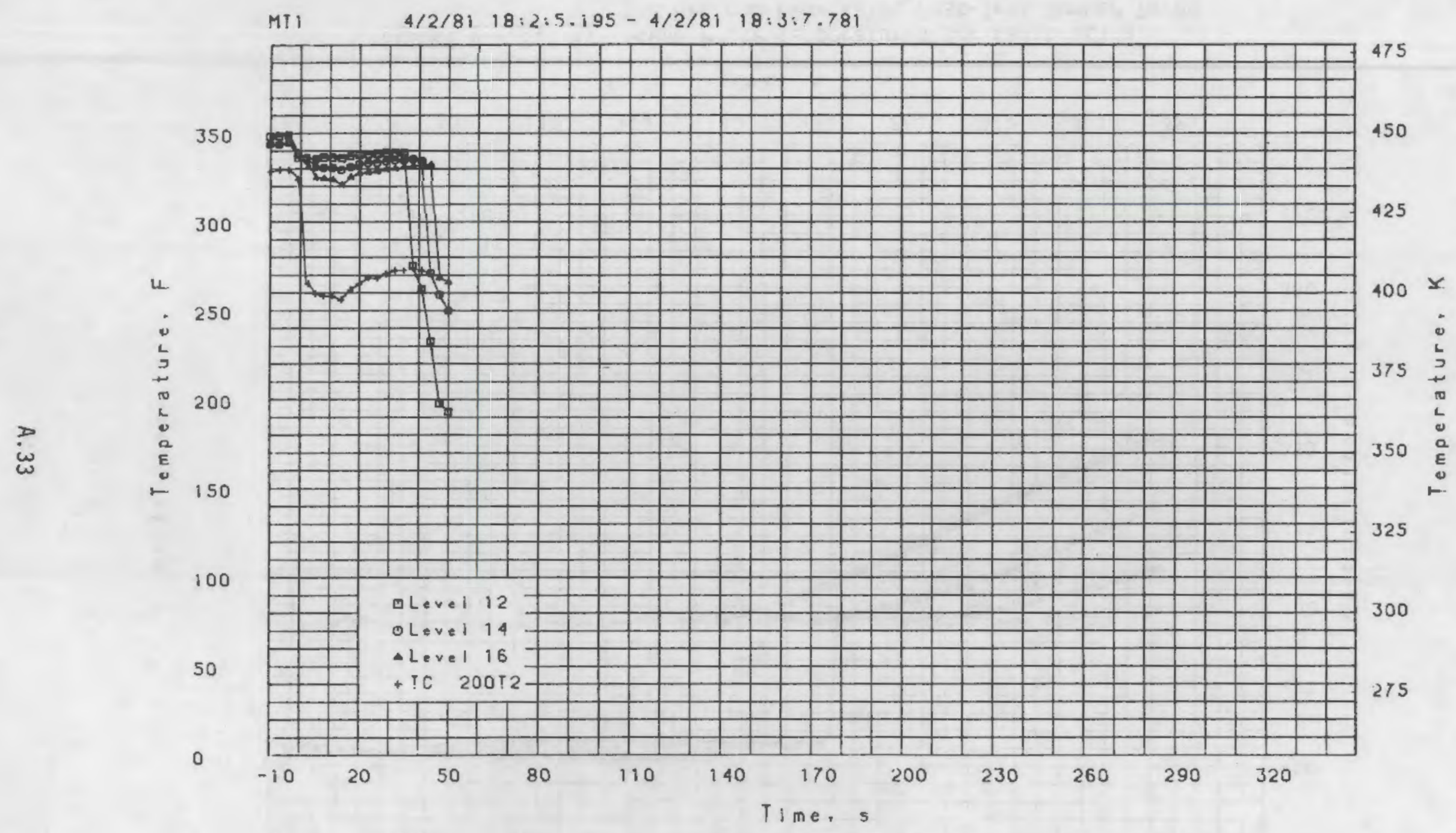

FIGURE A.4.2.2.2. Steam Probe Temperatures for Calibrating the Reflood Flow Rate, Post-Test Number Two 


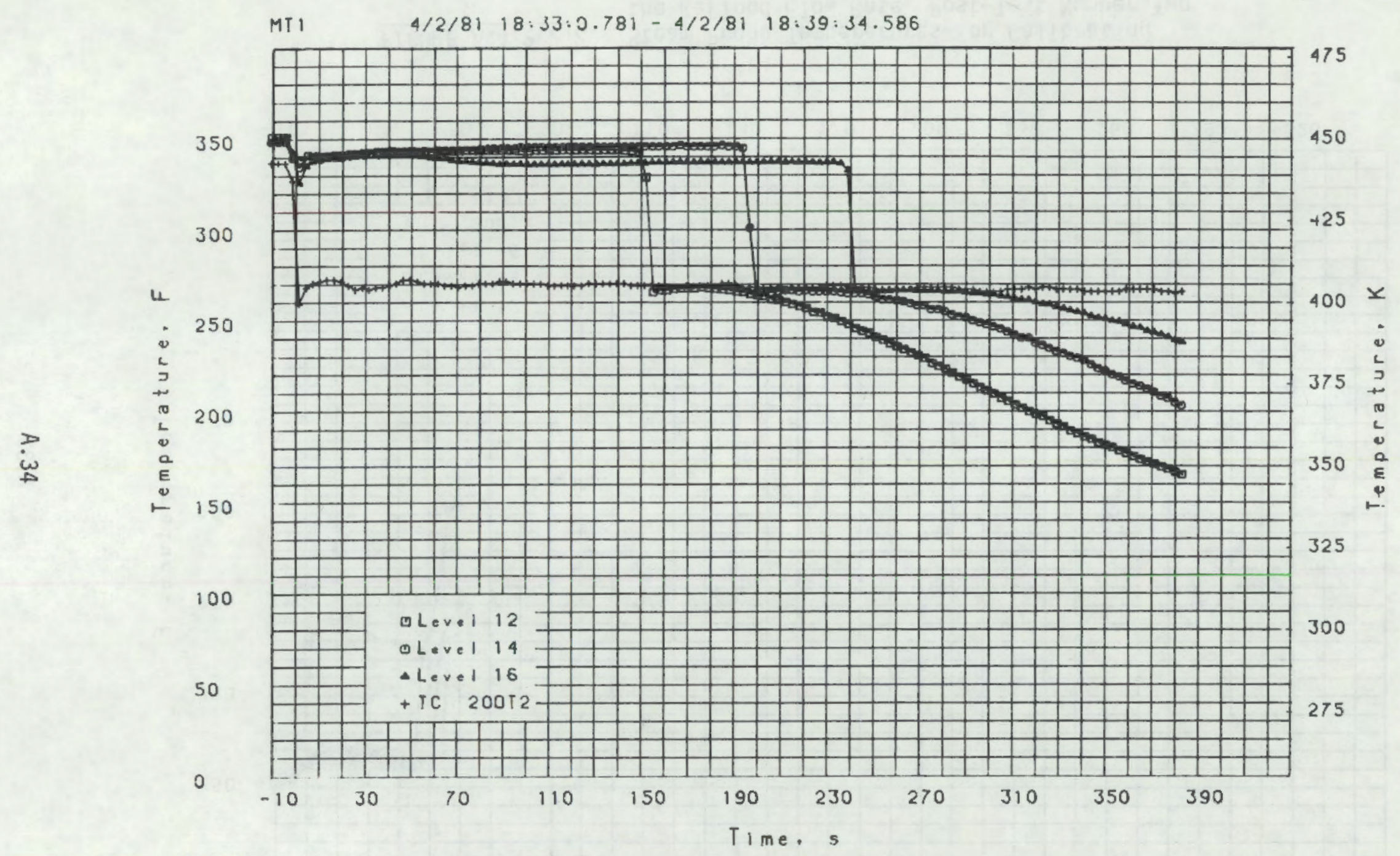

FIGURE A.4.2.2.3. Steam Probe Temperatures for Calibrating the Reflood Flow Rate, Post-Test Number Three 


\section{SECTION 5}

MT-1 TRANSIENT REFLOOD DATA 


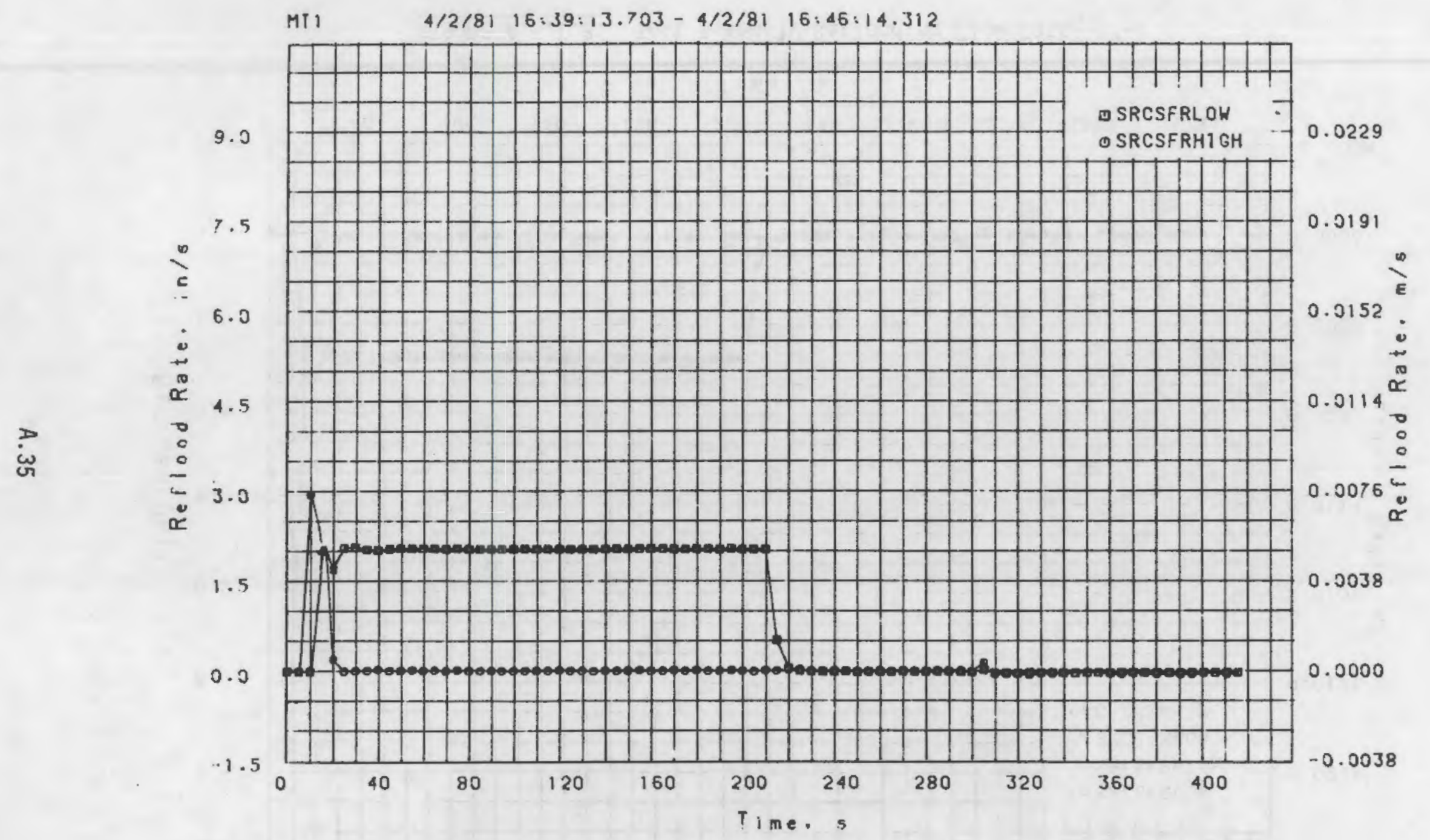

FIGURE A.5.1.1. Test Assembly Reflooding Flow Rate--MT-1 


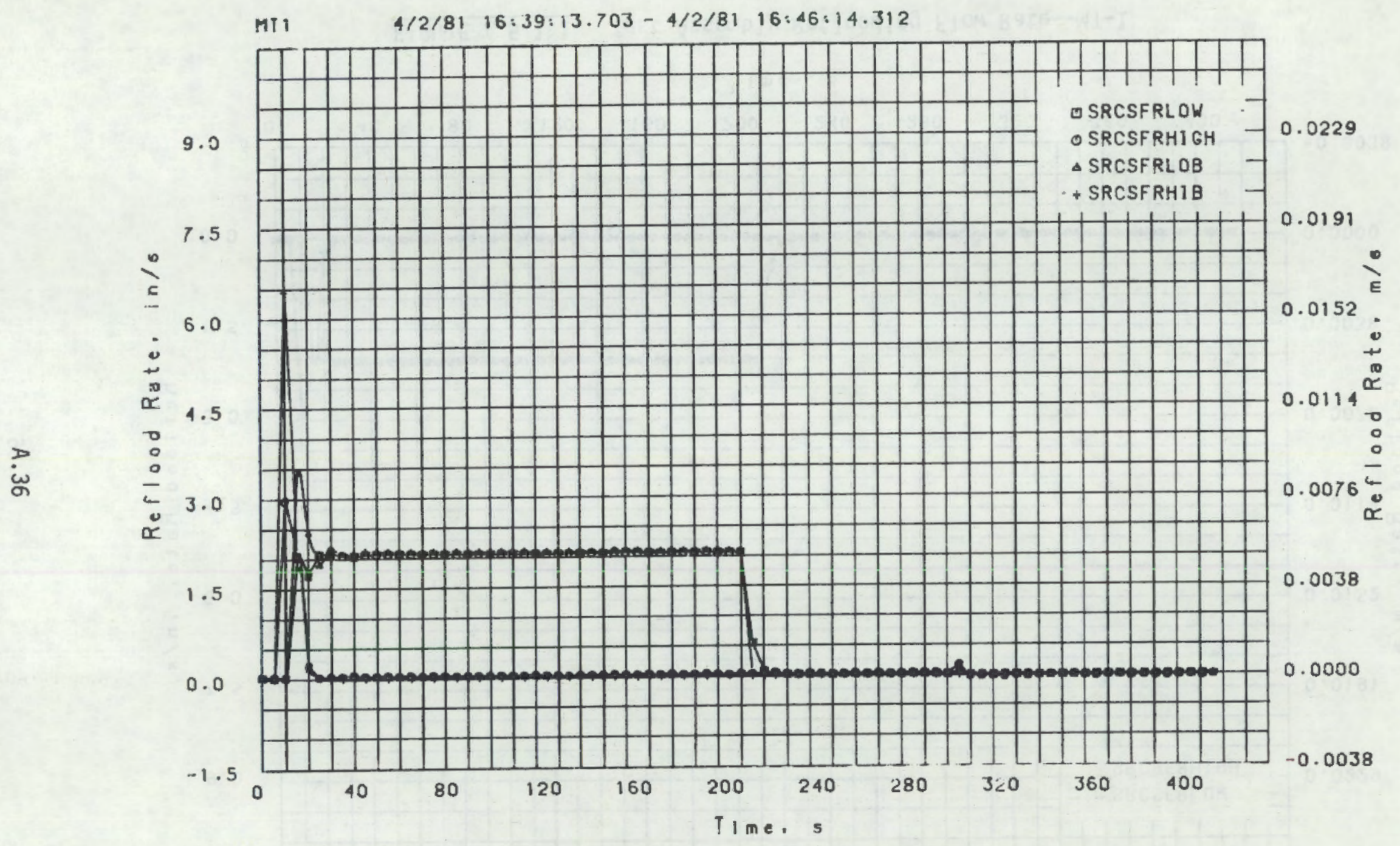

FIGURE A.5.1.2. Test Assembly Reflooding Flow Rate--MT-1 


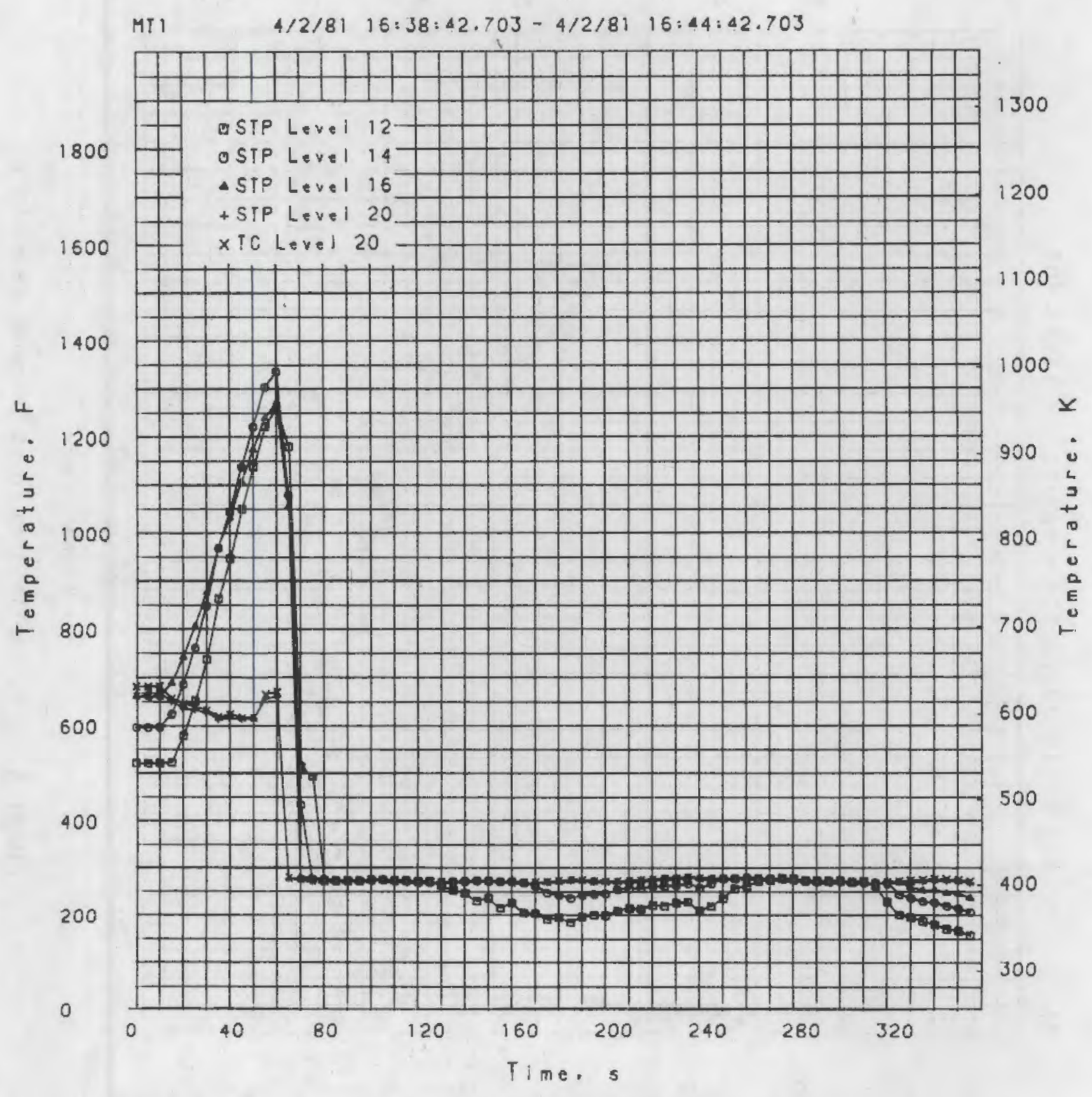

FIGURE A.5.2.1. Steam Probe and Outlet Region Temperature Histories During Transient MT-1 


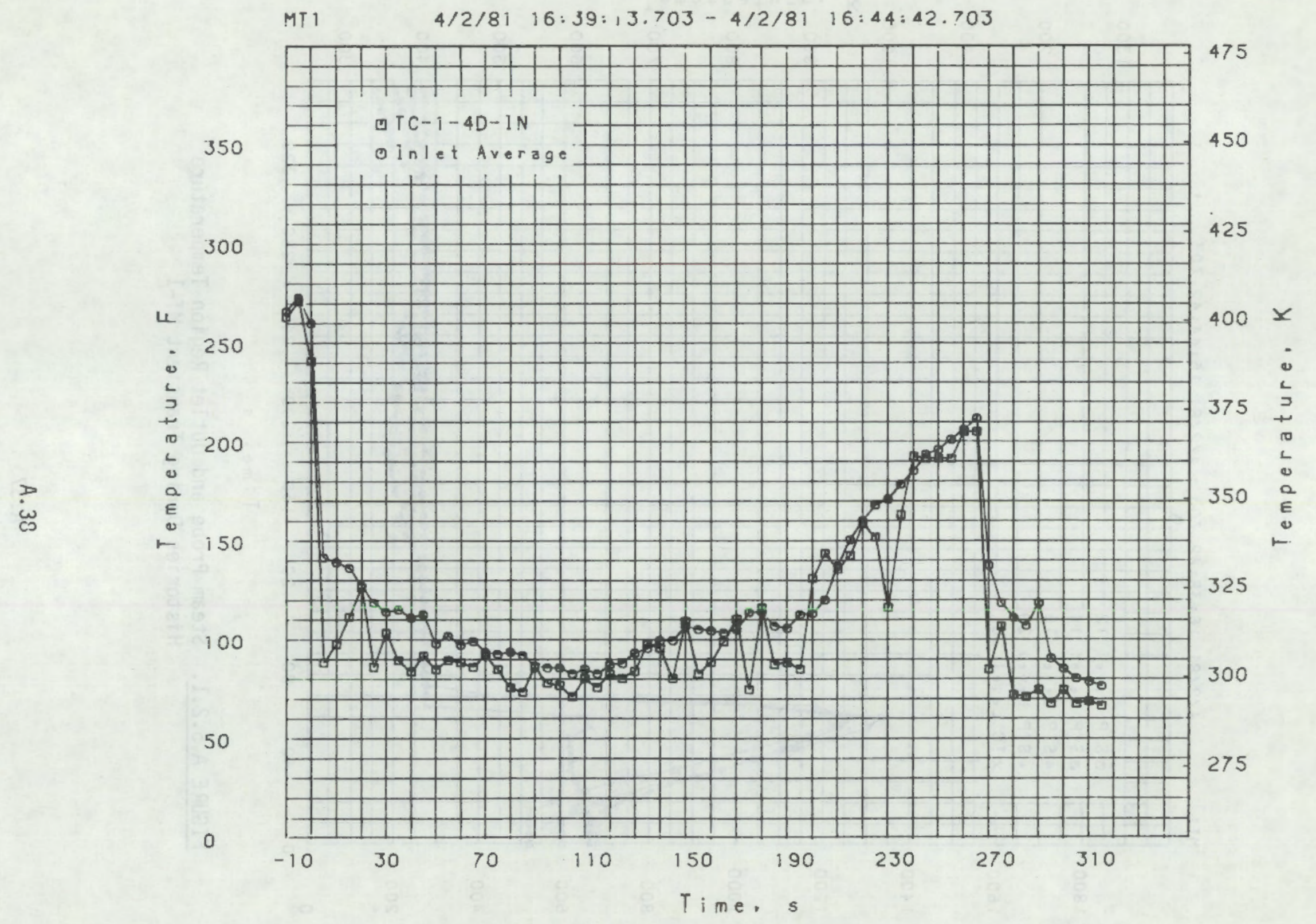

FIGURE A.5.2.2. Reflooding Inlet Temperature History 


\section{SECTION 6}

FUEL ROD PRESSURE DATA 


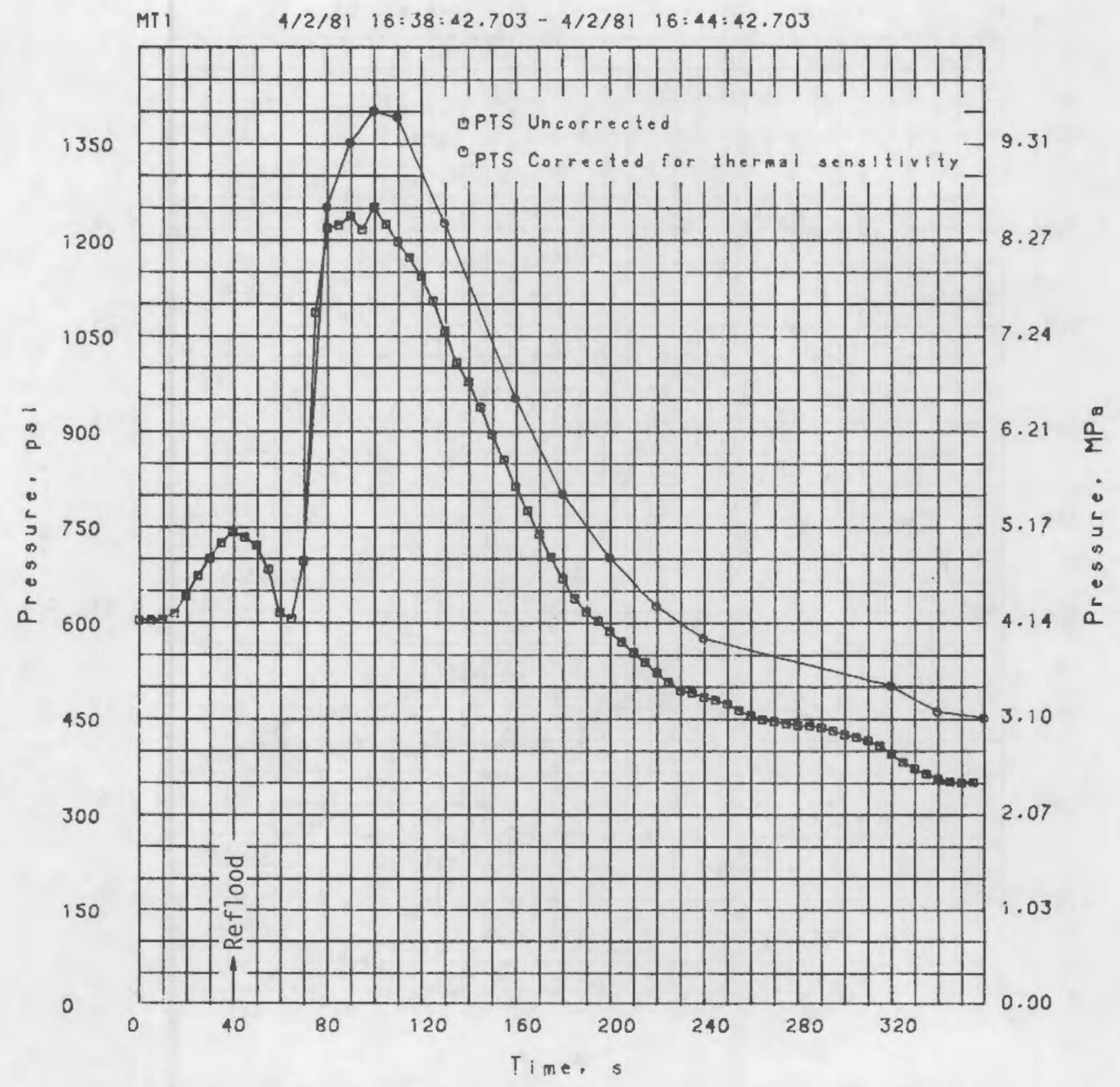

FIGURE A.6.1.1. Fuel Rod Pressure Transducer Data for Fuel Rods in Positions $5 C$ (PTS) and $3 C$ (PTK) During the MT-1 Transient 


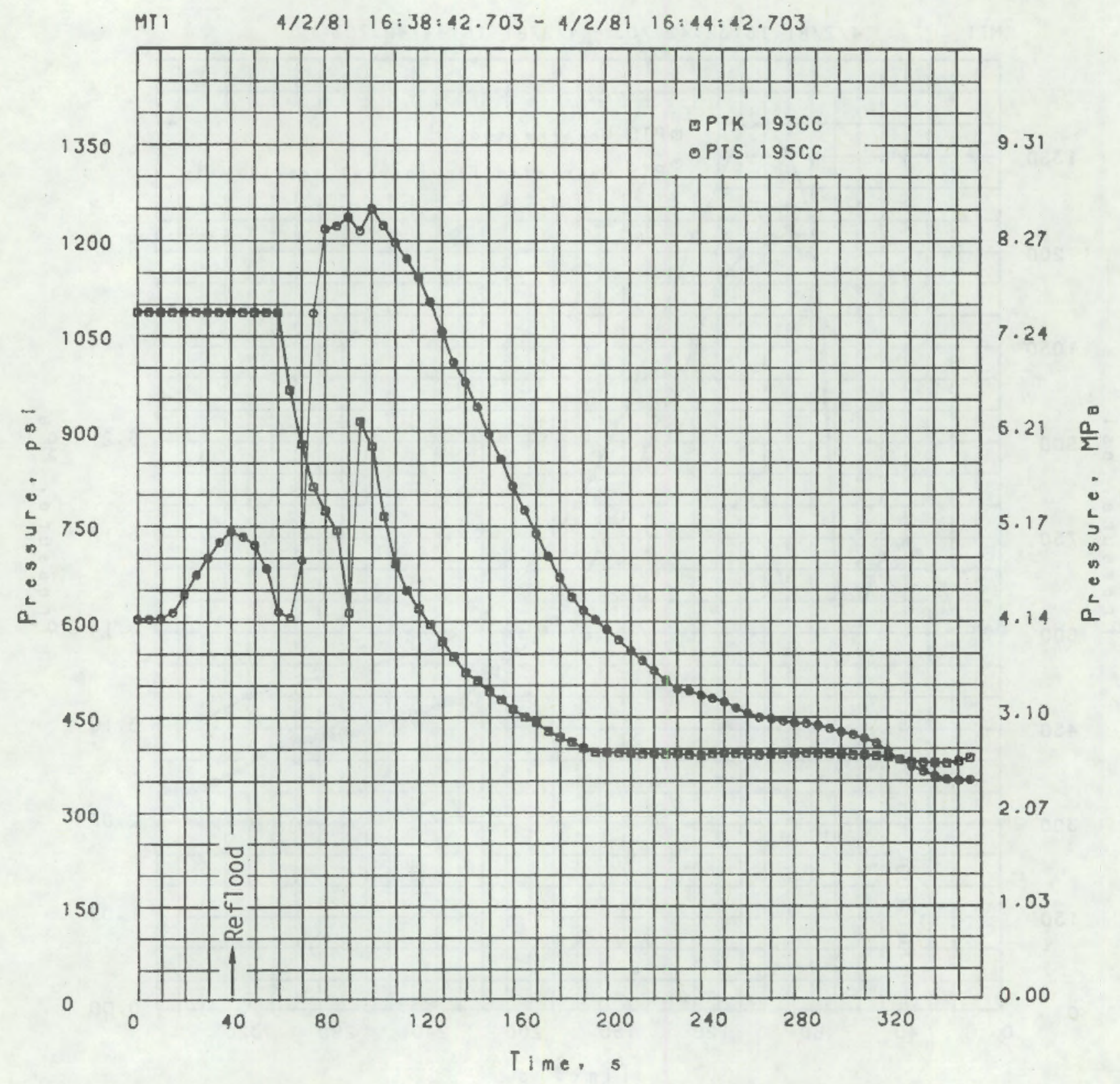

FIGURE A.6.1.2. Temperature Corrected Fuel Rod (5C) Plenum Pressure History During the MT-1 Transient 


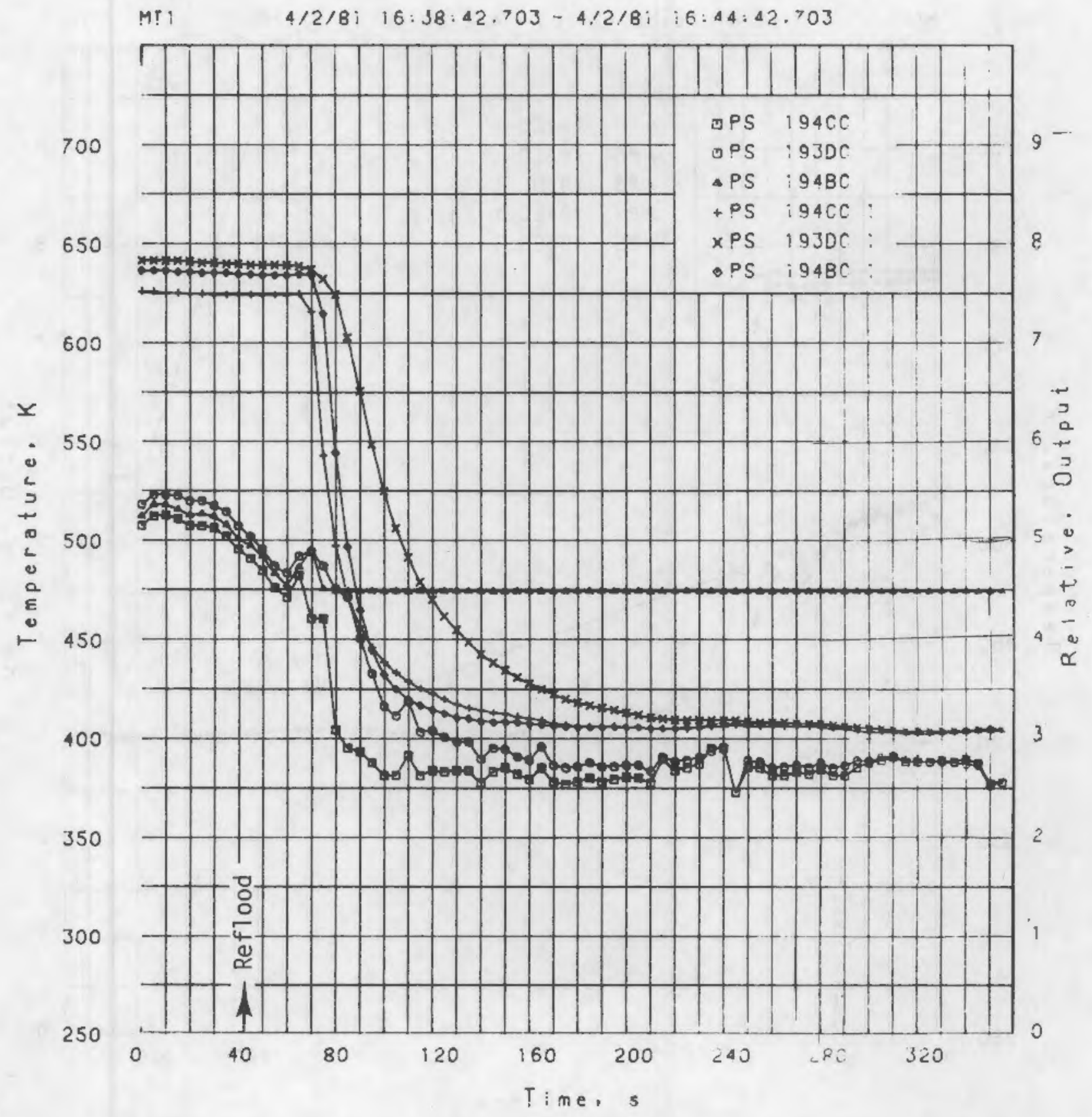

FIGURE A.6.2.1. Pressure Switch Response During the MT-1 Transient 


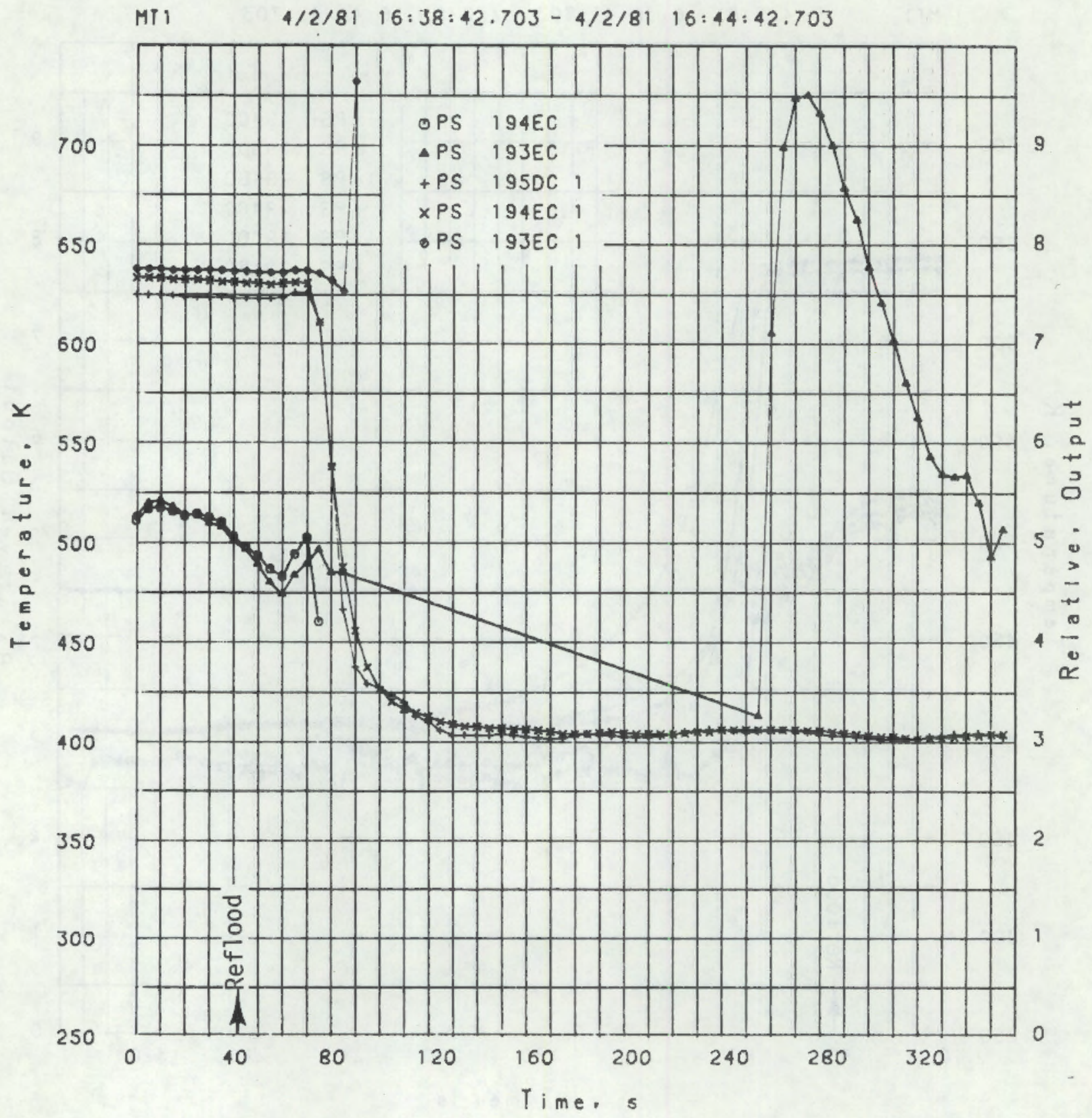

FIGURE A.6.2.2. Pressure Switch Response During the MT-1 Transient 


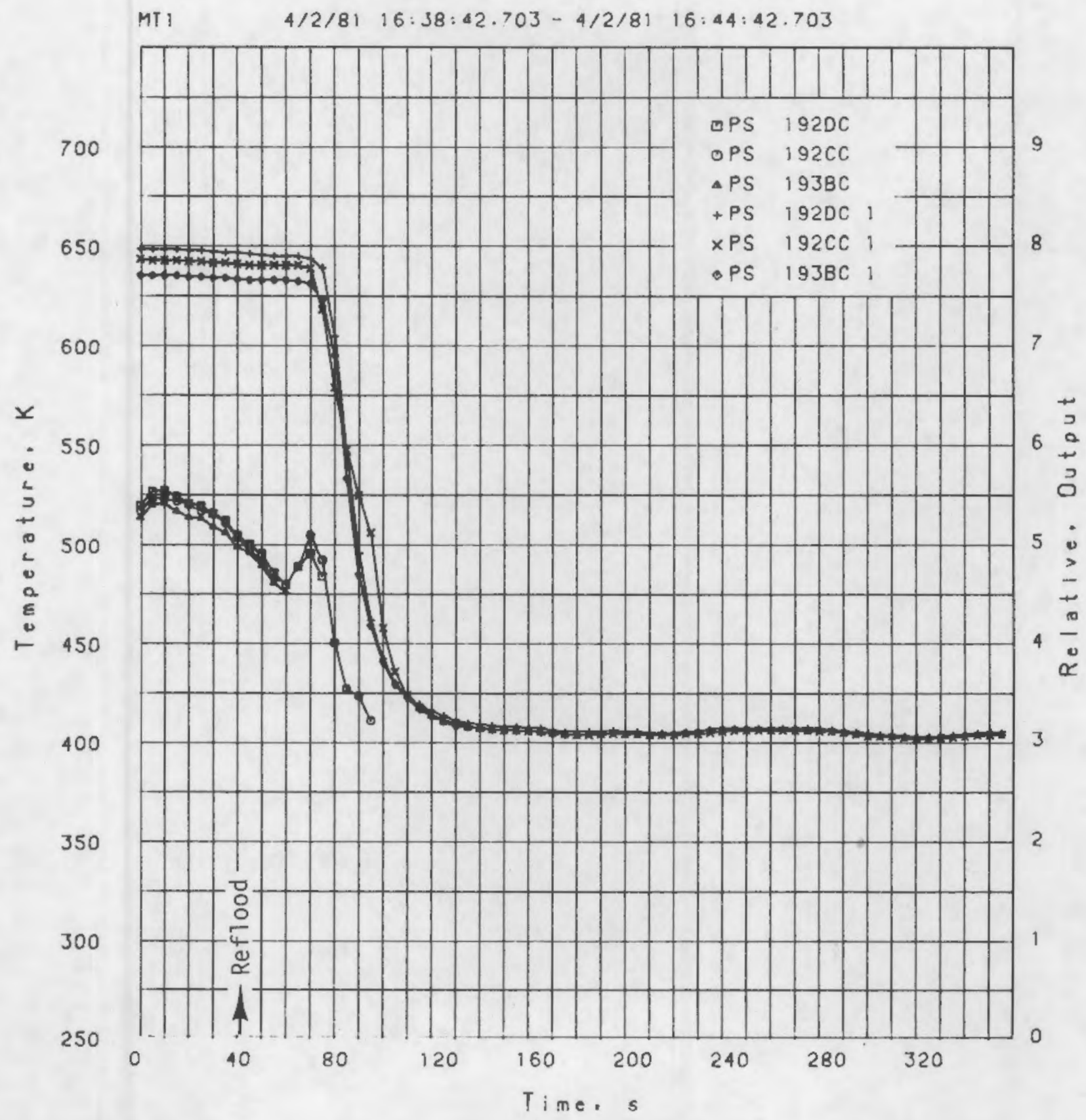

FIGURE A.6.2.3. Pressure Switch Response During the MT-1 Transient 



\section{APPENDIX B}

\section{PTH-110 GRAPHICAL DATA}

Section 1 Temperature

1.1 Preconditioning

1.2 Pretransient and Transient

Section 2 Neutron Flux

2.1 Preconditioning

2.2 Pretransient and Transient

Section 3 Steam Probe Temperature

3.1 Preconditioning

3.2 Pretransient and Transient

Section $4 \quad$ Flow Test Reflood

4.1 Flow Rates

4.2 Steam Probe Temperatures

Section 5 PTH Transient Reflood

5.1 Flow Rates

5.2 Steam Probe Temperatures

(See Section 3.2) 

SECTION 1

TEMPERATURE DATA 


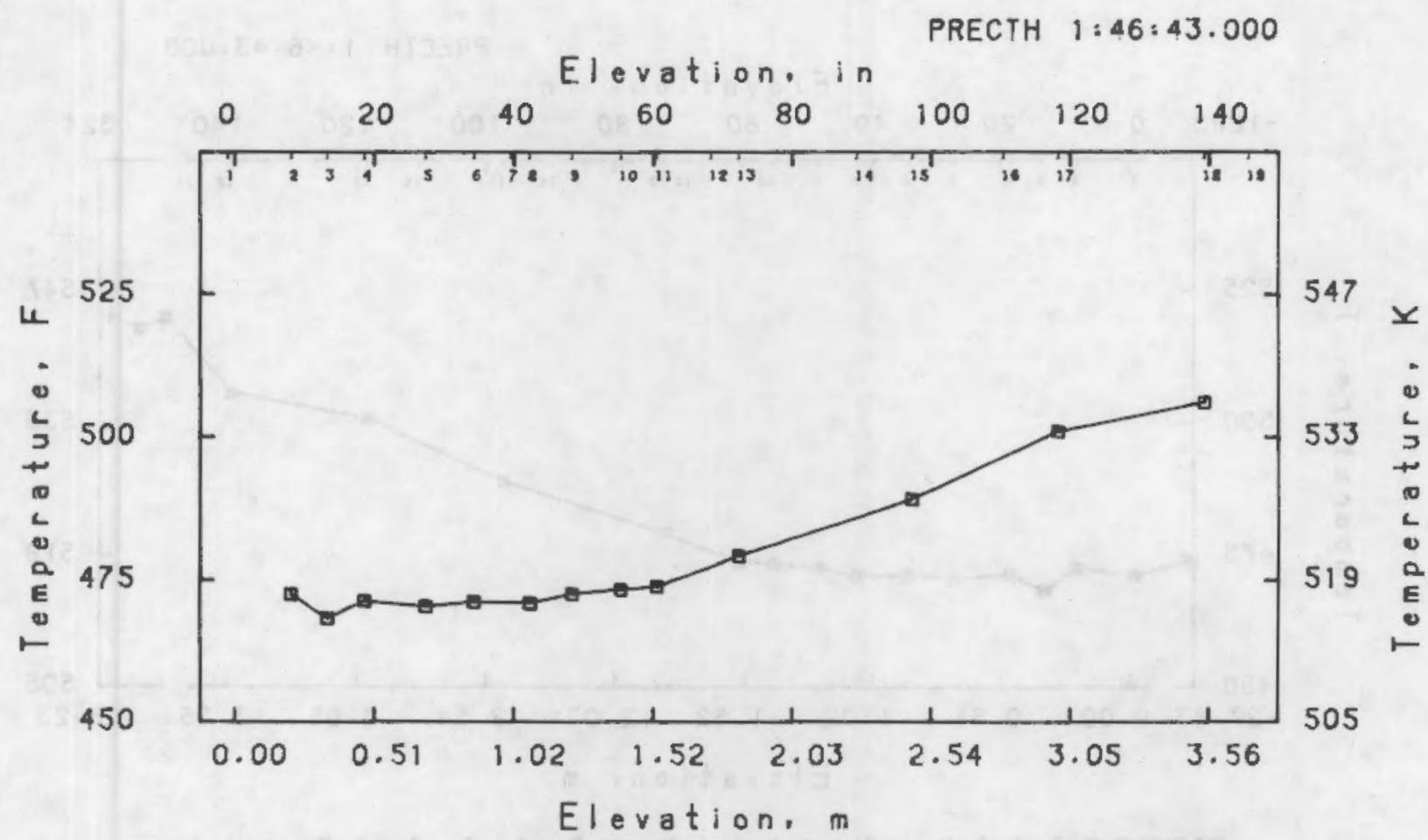

FIGURE B.1.1.1.1. Average Shroud Axial Temperature Profile

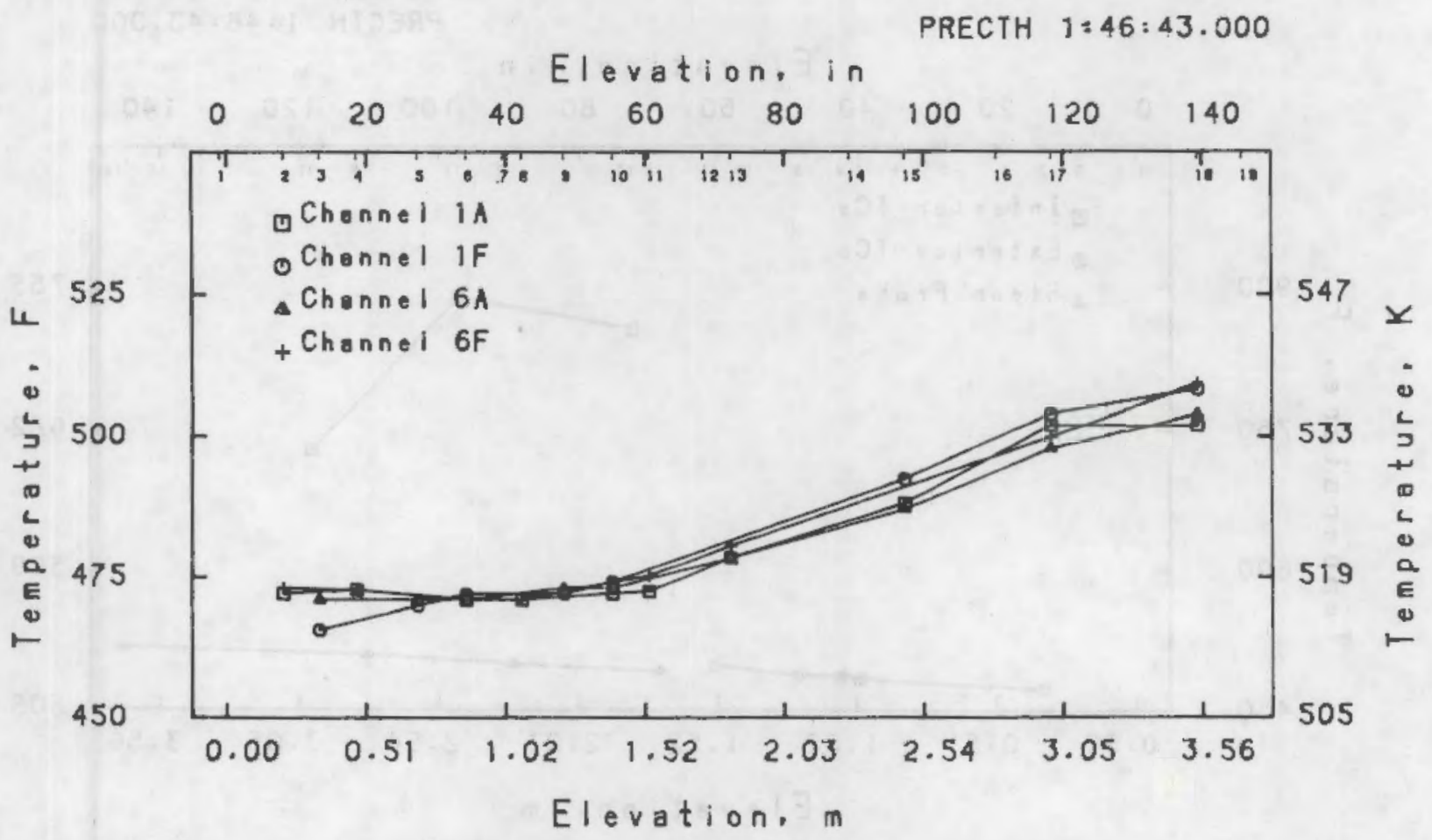

FIGURE B.1.1.1.2. Shroud Axial Temperature Profiles 


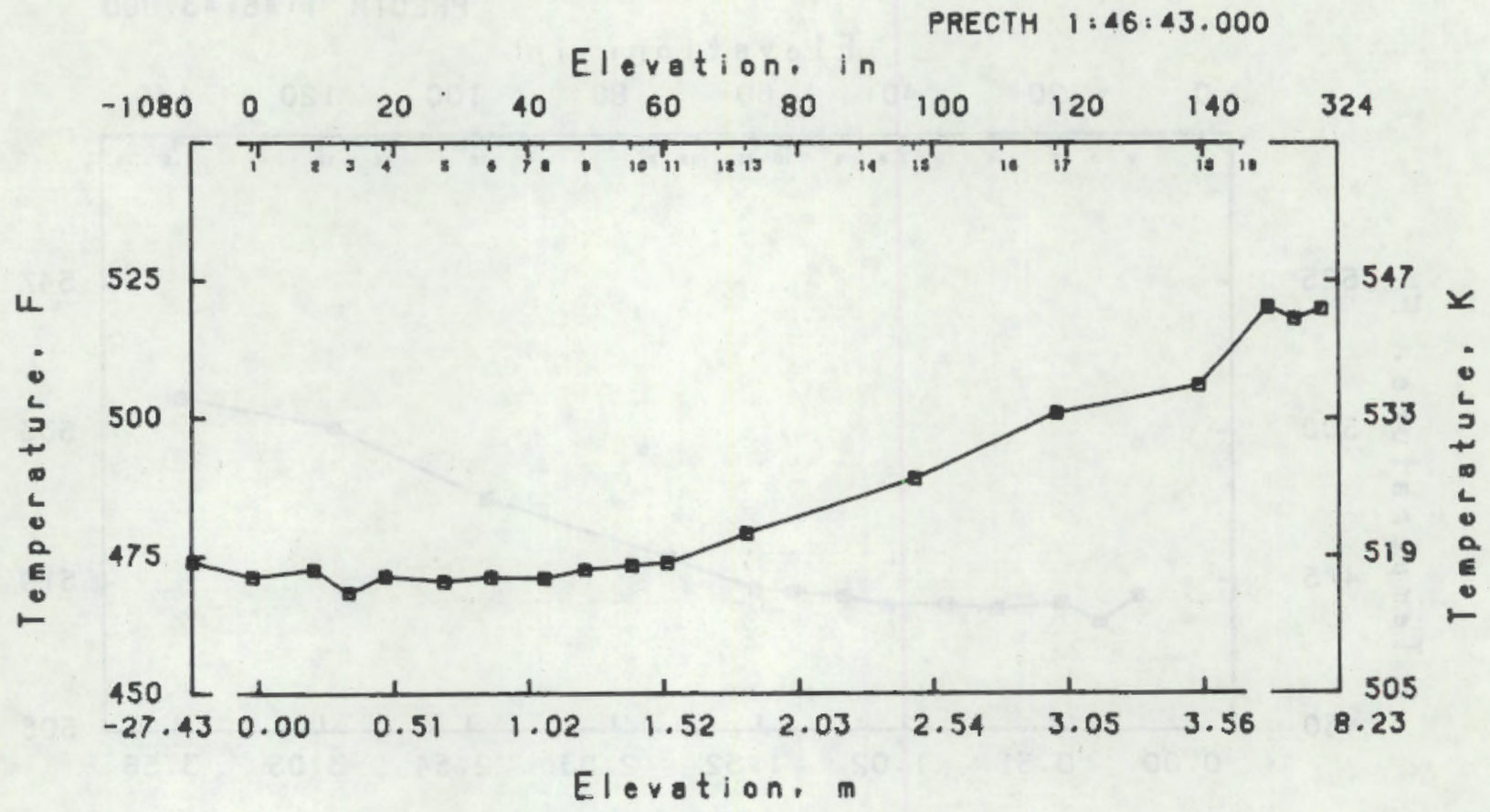

FIGURE B.1.1.1.3. Shroud and Test Train Coolant Temperatures

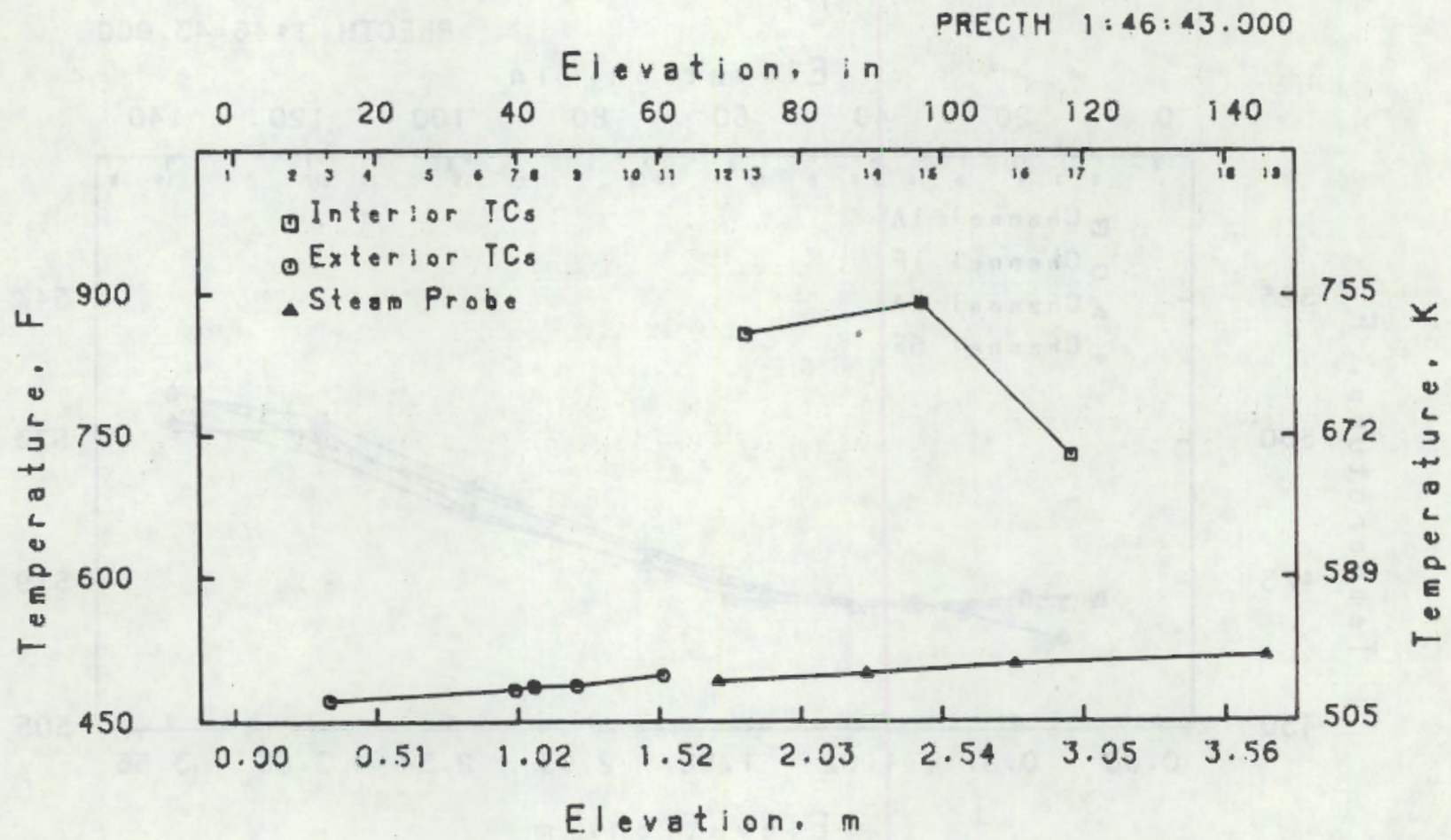

FIGURE B.1.1.2.1. Average Guard Fuel Rod Cladding Temperature Profiles-Interior and Exterior TC's, Preconditioning PTH-110 


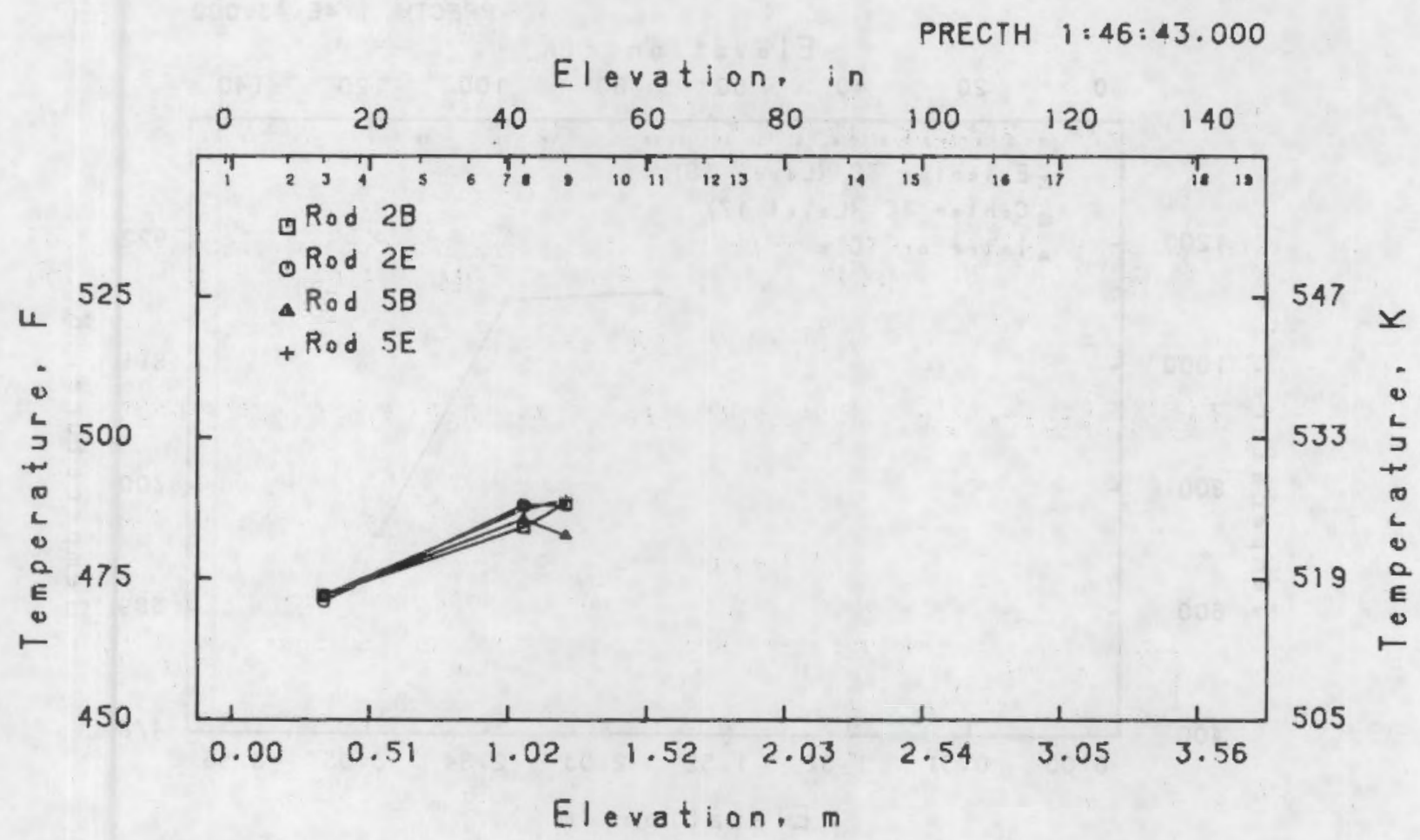

FIGURE B.1.1.2.2. Individual Guard Fuel Rod $\mathrm{Cl}$ adding Exterior Temperature Profiles During Preconditioning 


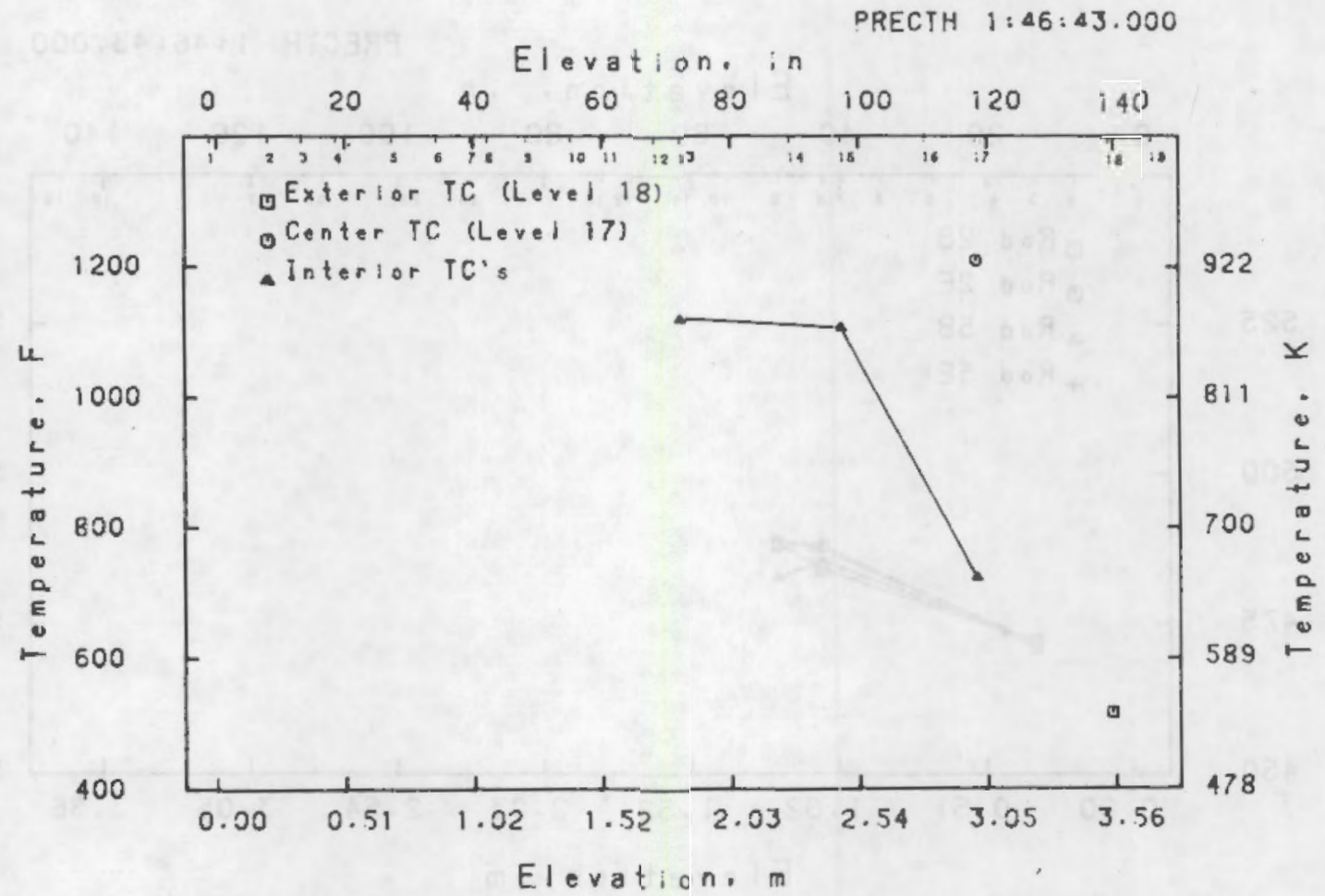

FIGURE B.1.1.3.1. Average Test Fuel Rod Temperature Profiles-Exterior, Interior, and Center TC for PTH-110 Preconditioning 
PTH110 14:50:7.039

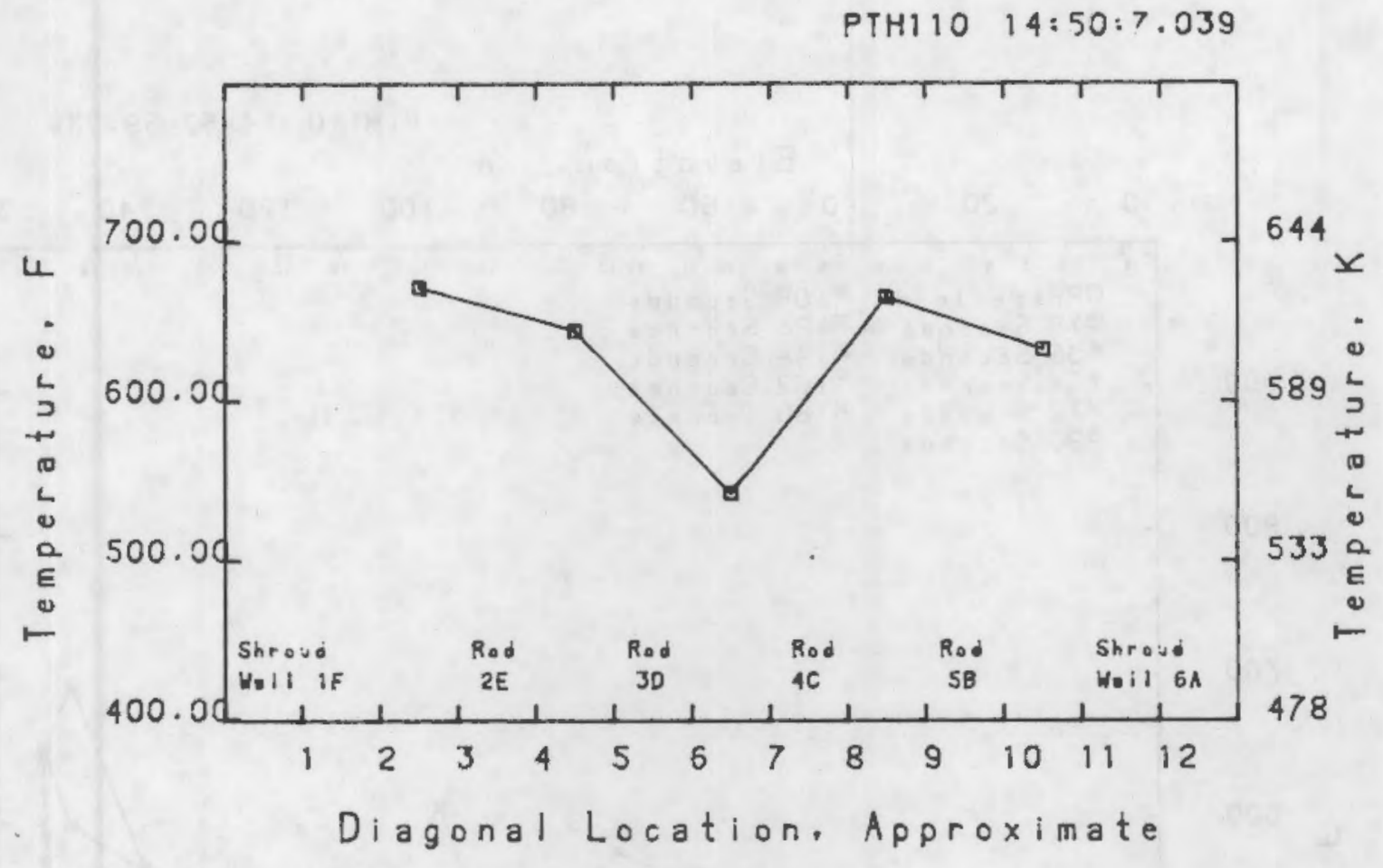

FIGURE B.1.2.1.1. Diagonal Temperature Profile Across Test Assembly Coolant During Pretransient - Level 16

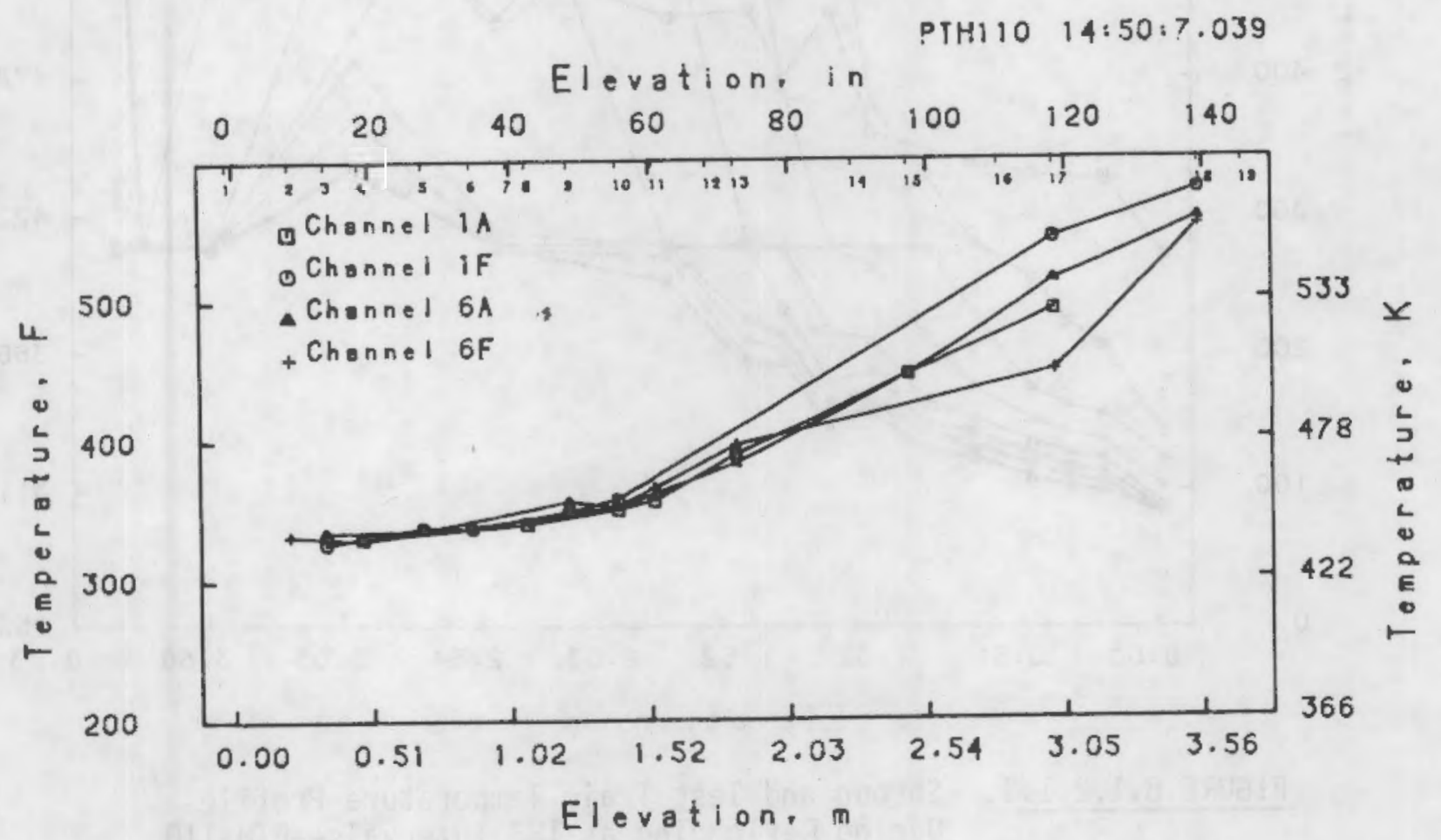

FIGURE B.1.2.1.2. Shroud Axial Temperature Profiles-Pretransient PTH-110 


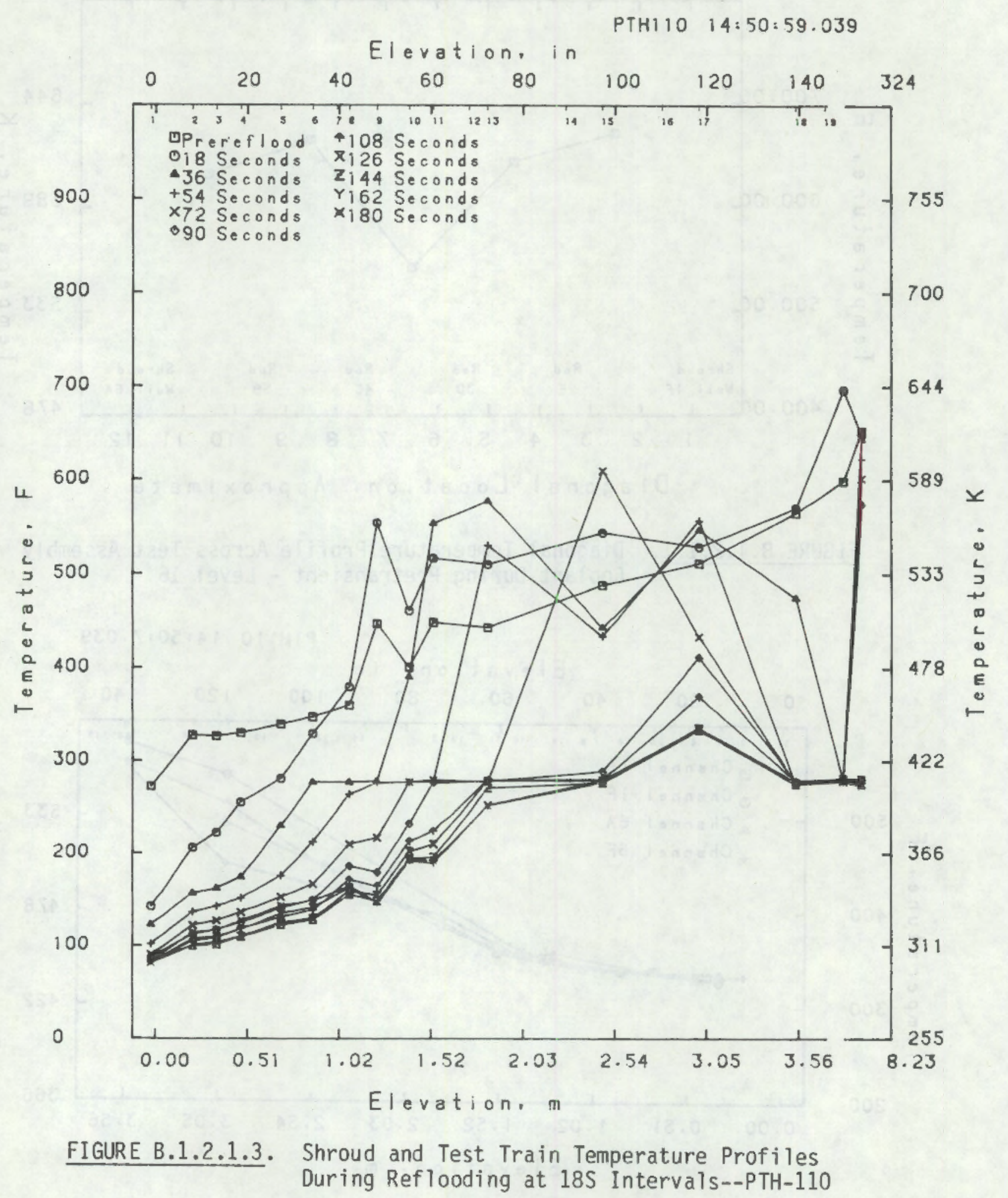




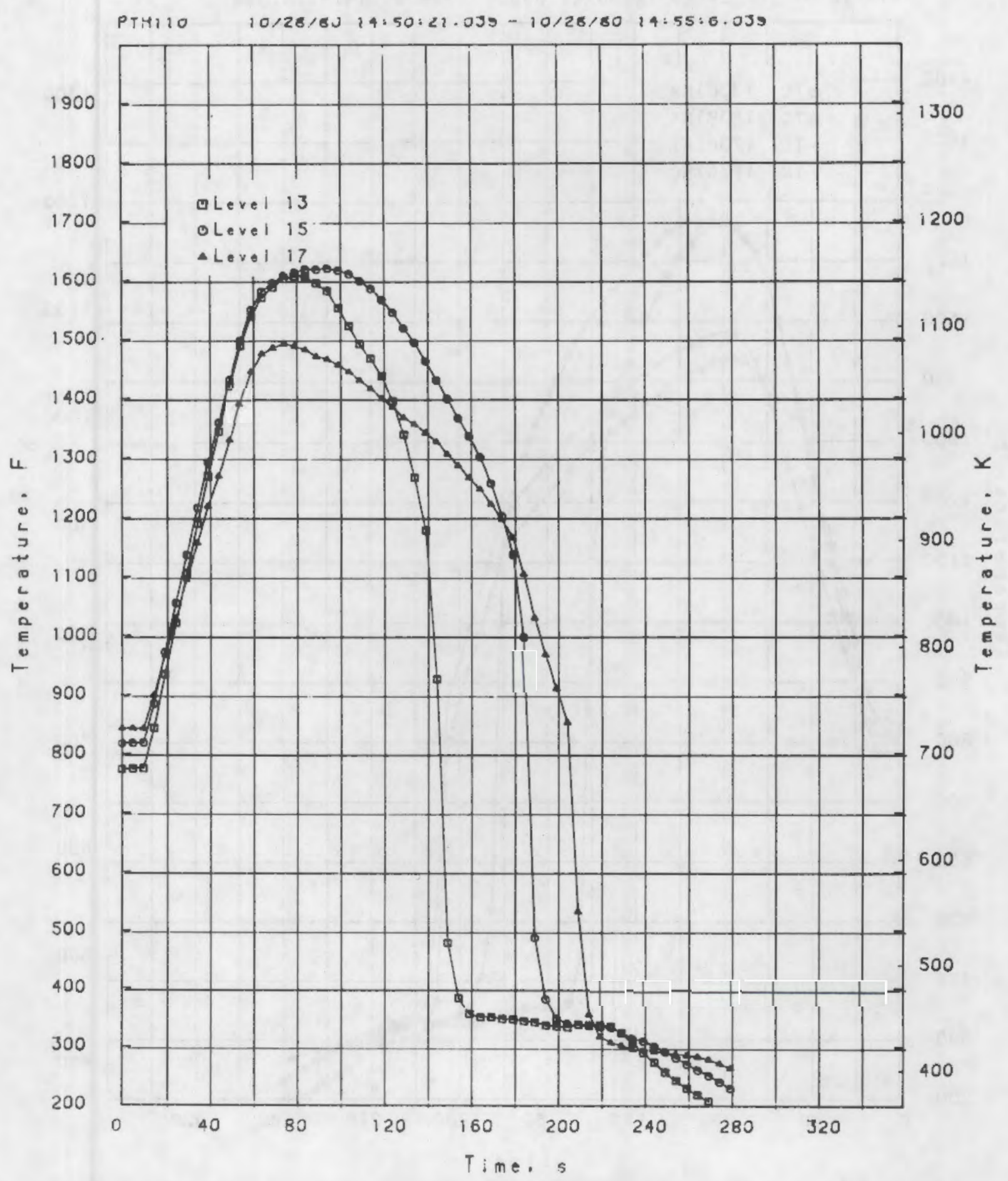

FIGURE B.1.2.2. Average Guard Fuel Rod $\mathrm{Cl}$ adding Temperature Histories (Interior TC's) During Transient PTH-110 


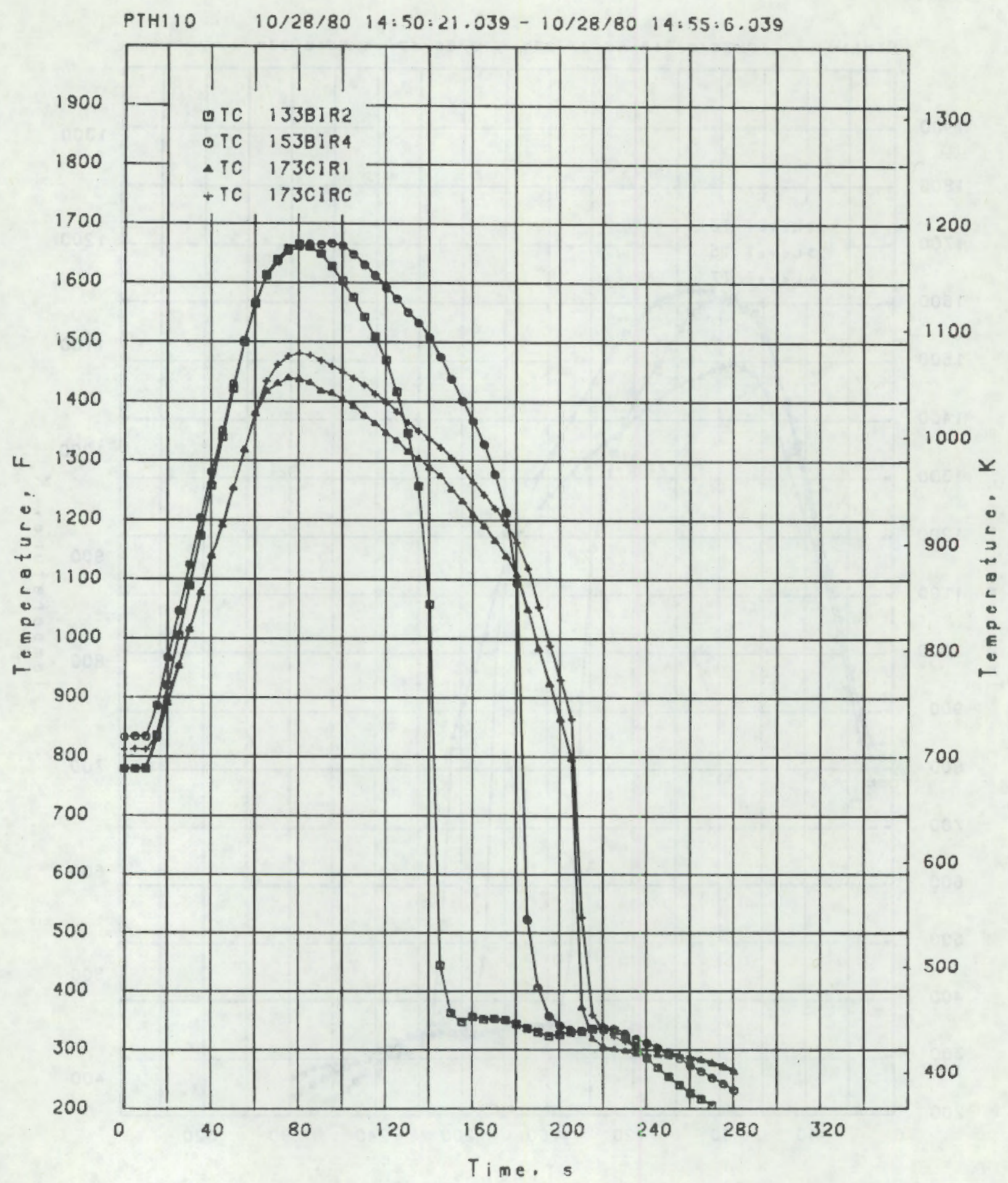

FIGURE B.1.2.3. Test Fuel Rod Center and Interior Cladding Temperature Histories During Transient PTH-110 
SECTION 2

NEUTRON FLUX DATA 


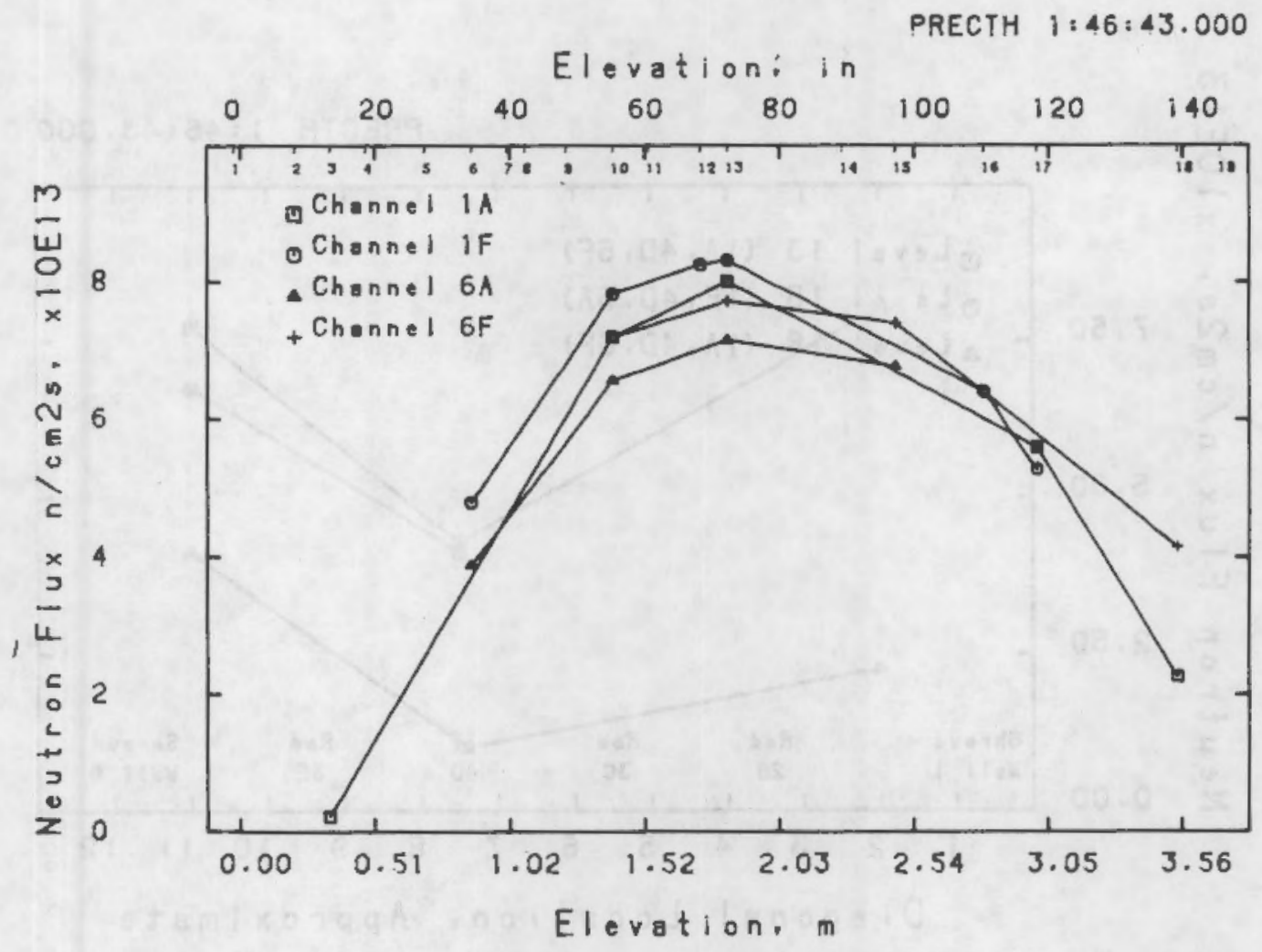

FIGURE B.2.1.1. Preconditioning (Shroud) Neutron Flux Axial Profiles 


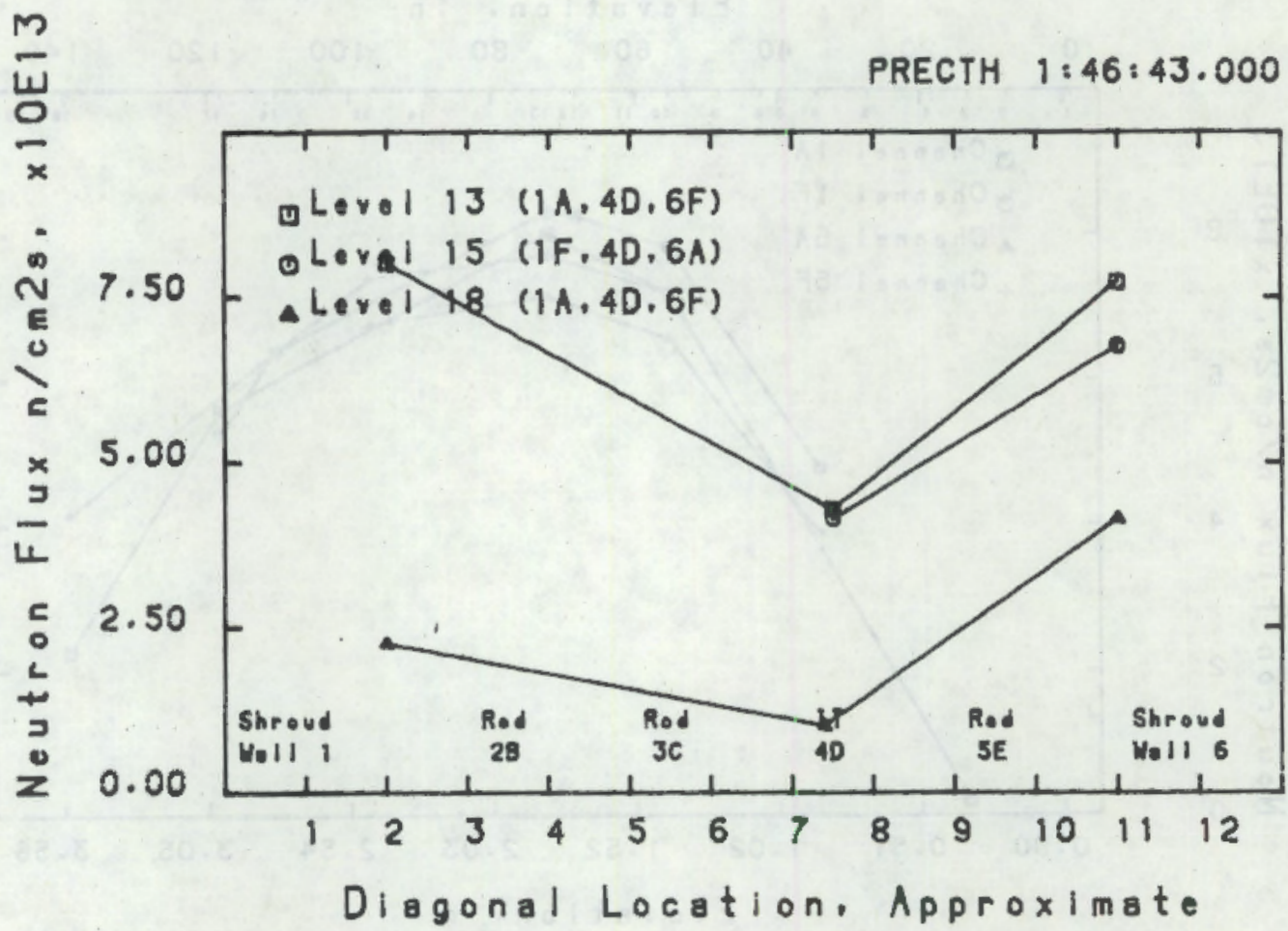

FIGURE B.2.1.2. Diagonal Neutron Flux Profile Across Test Assembly--Preconditioning 


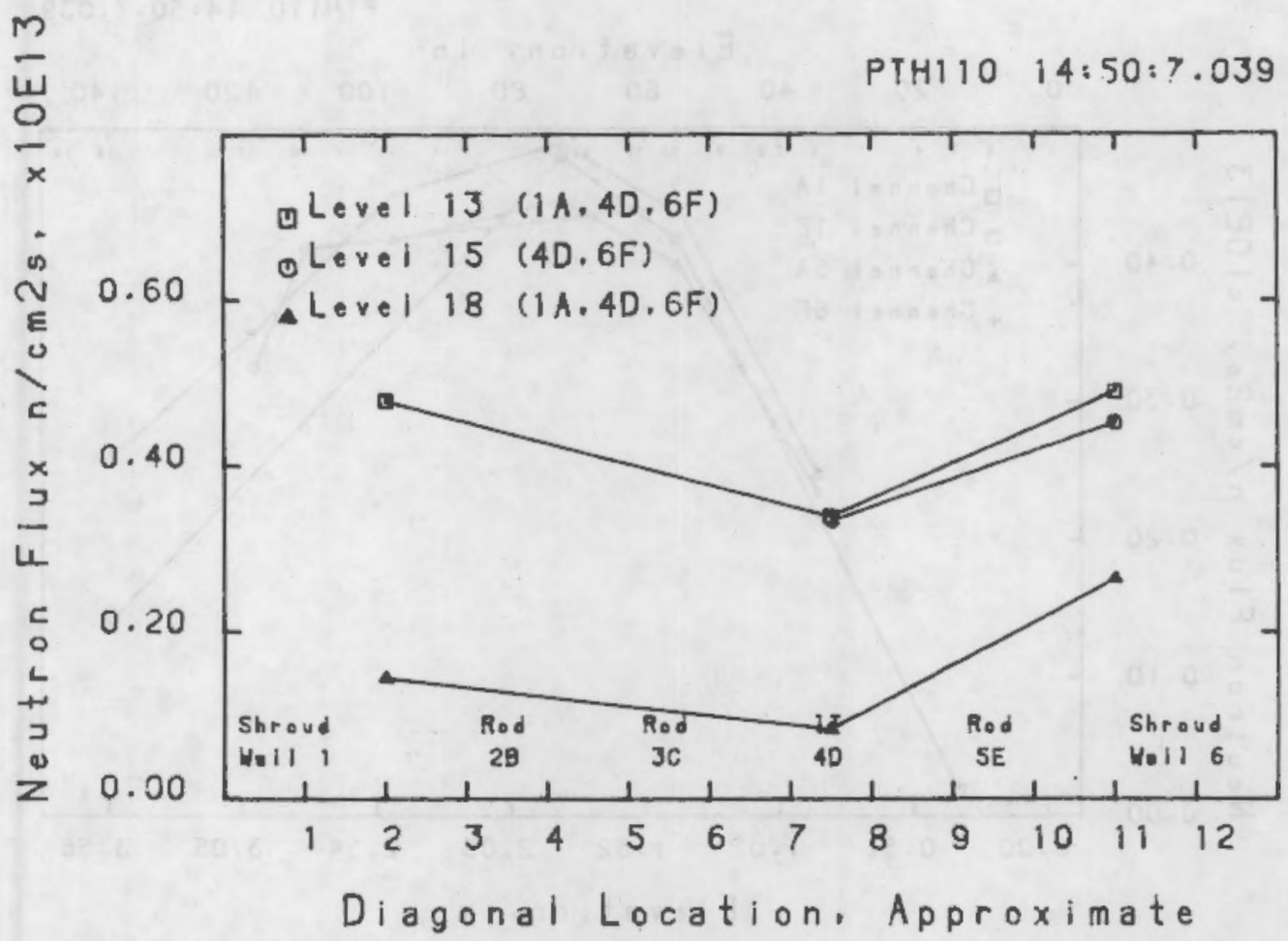

FIGURE B.2.2.1.1. Diagonal Neutron Flux Profile Across the Test Assembly--Pretransient PTH-110 


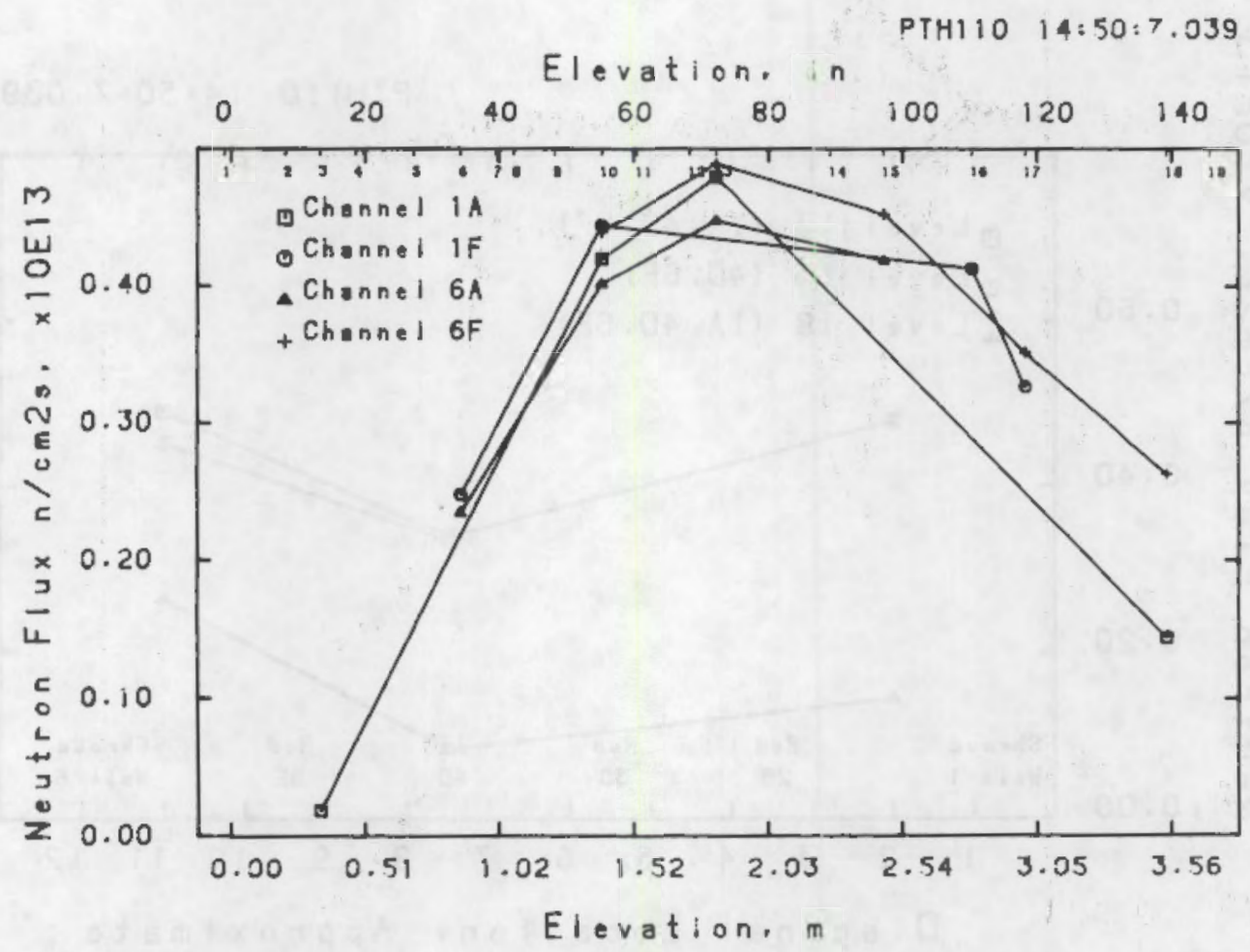

FIGURE B.2.2.1.2. Pretransient Shroud Neutron Flux Axial Profiles 
PTHI10 14:50:30.000

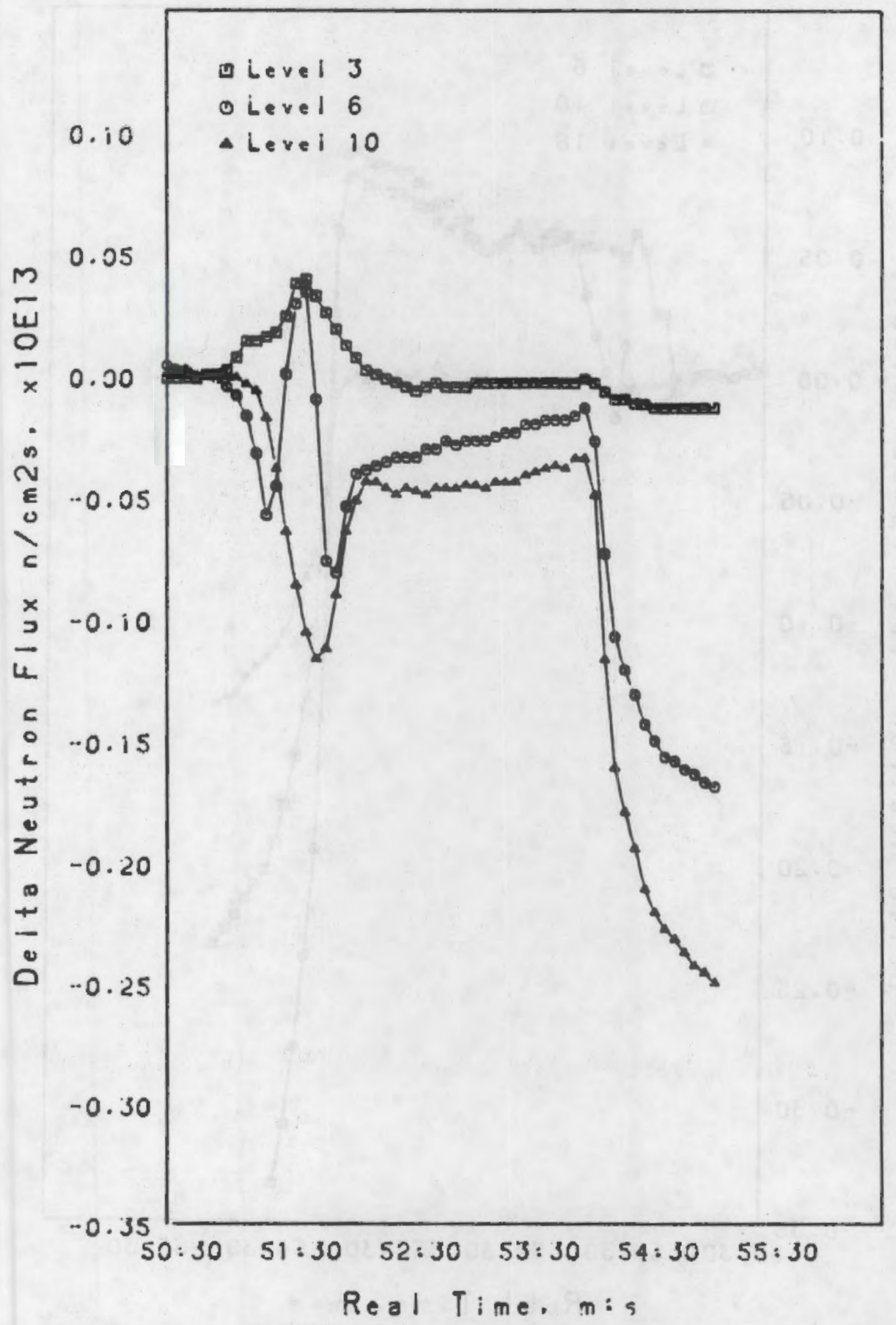

FIGURE B.2.2.2. Changing IT Neutron Flux After Reflooding Begins. $T=51 \mathrm{M}: 02 \mathrm{~S}$ 
PTH110 14:50:30.000

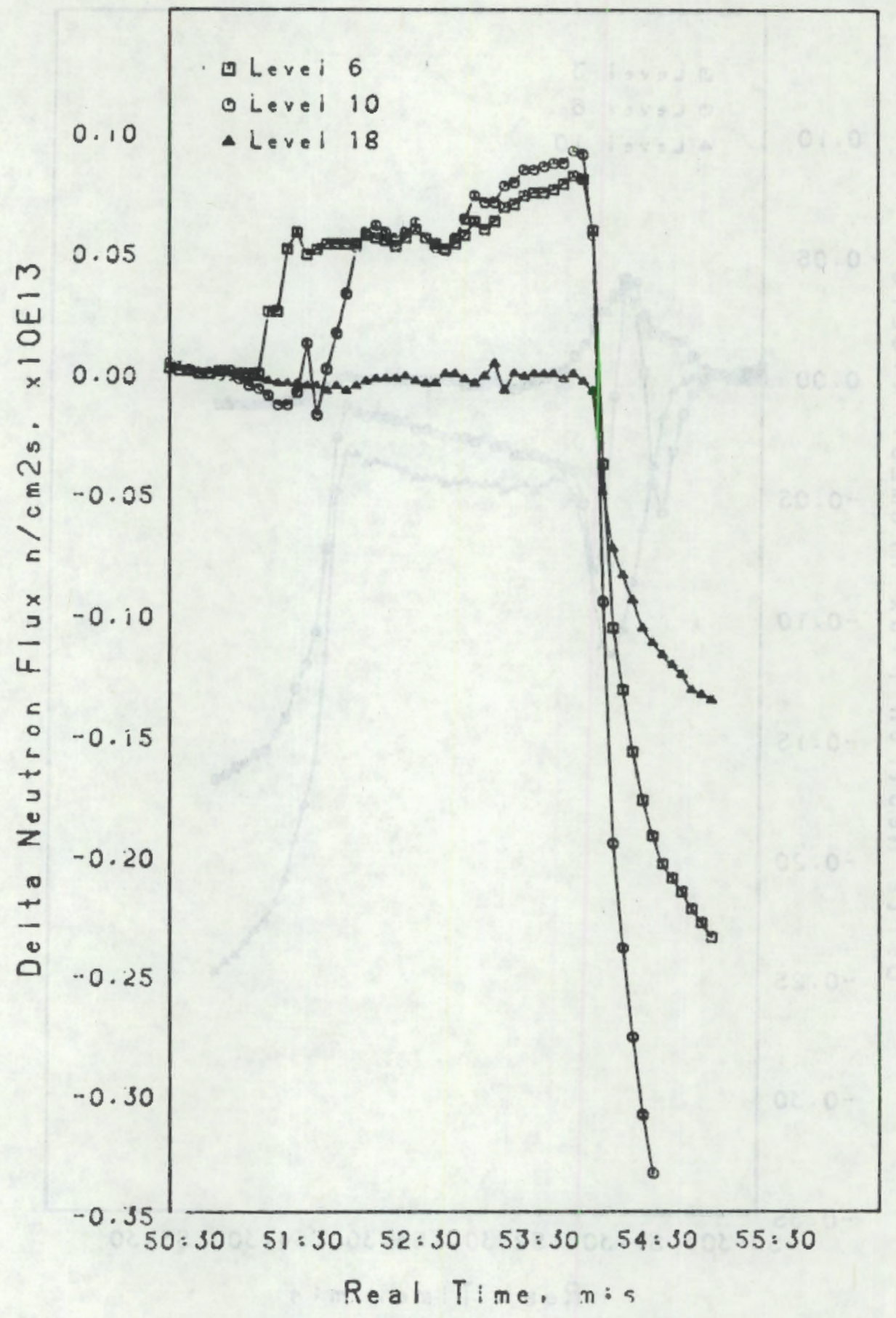

FIGURE B.2.2.3. Changing Neutron Flux (Shroud) After Reflooding Begins. $T=51 \mathrm{M}: 02 \mathrm{~S}$ 


\section{SECTION 3}

STEAM PROBE TEMPERATURE DATA 


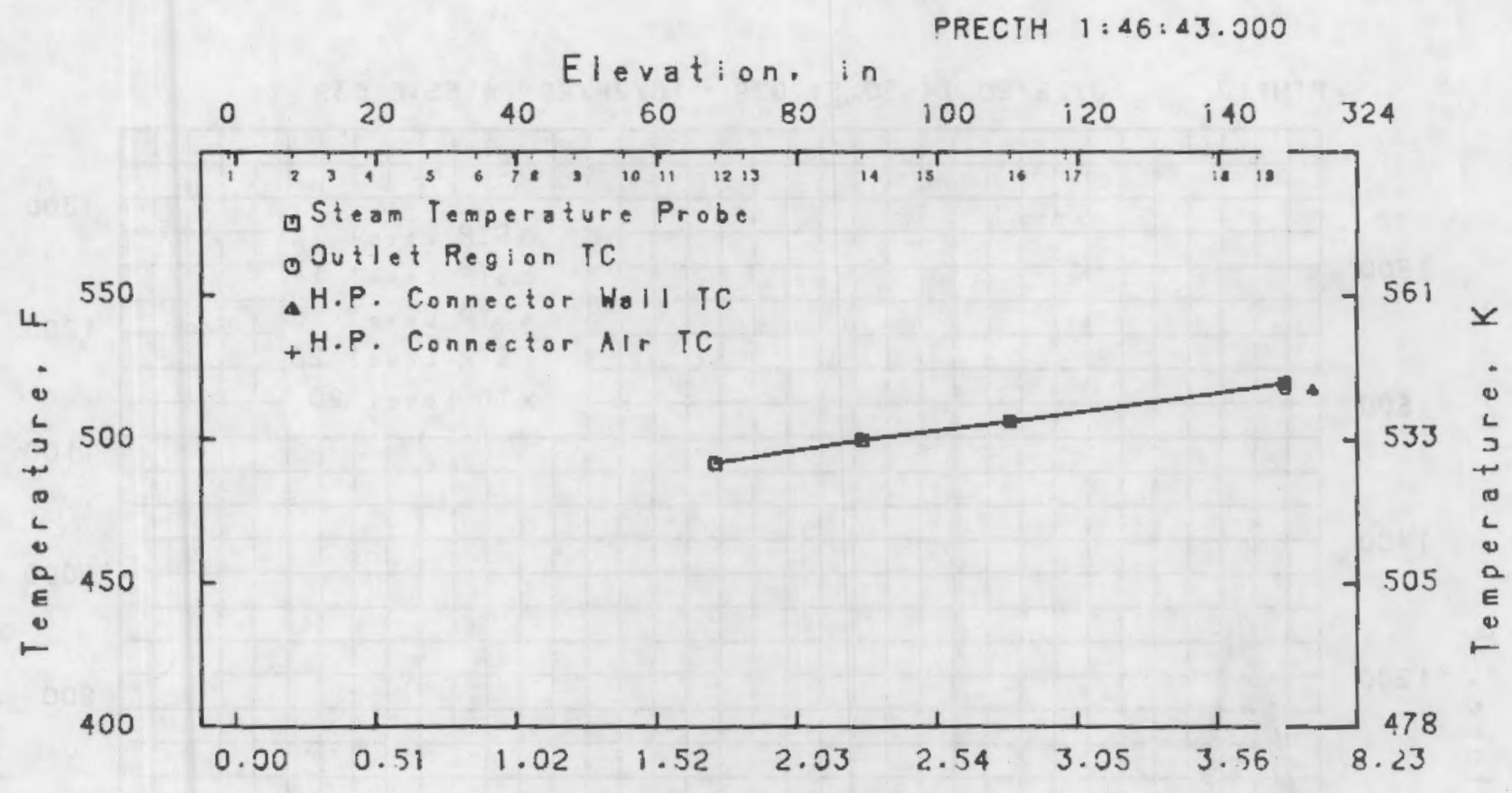

Elevation.m

FIGURE B.3.1.1. Average Steam Probe and HP Connector Temperature Profile (In Water, During Preconditioning)

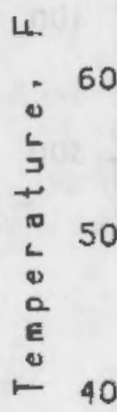

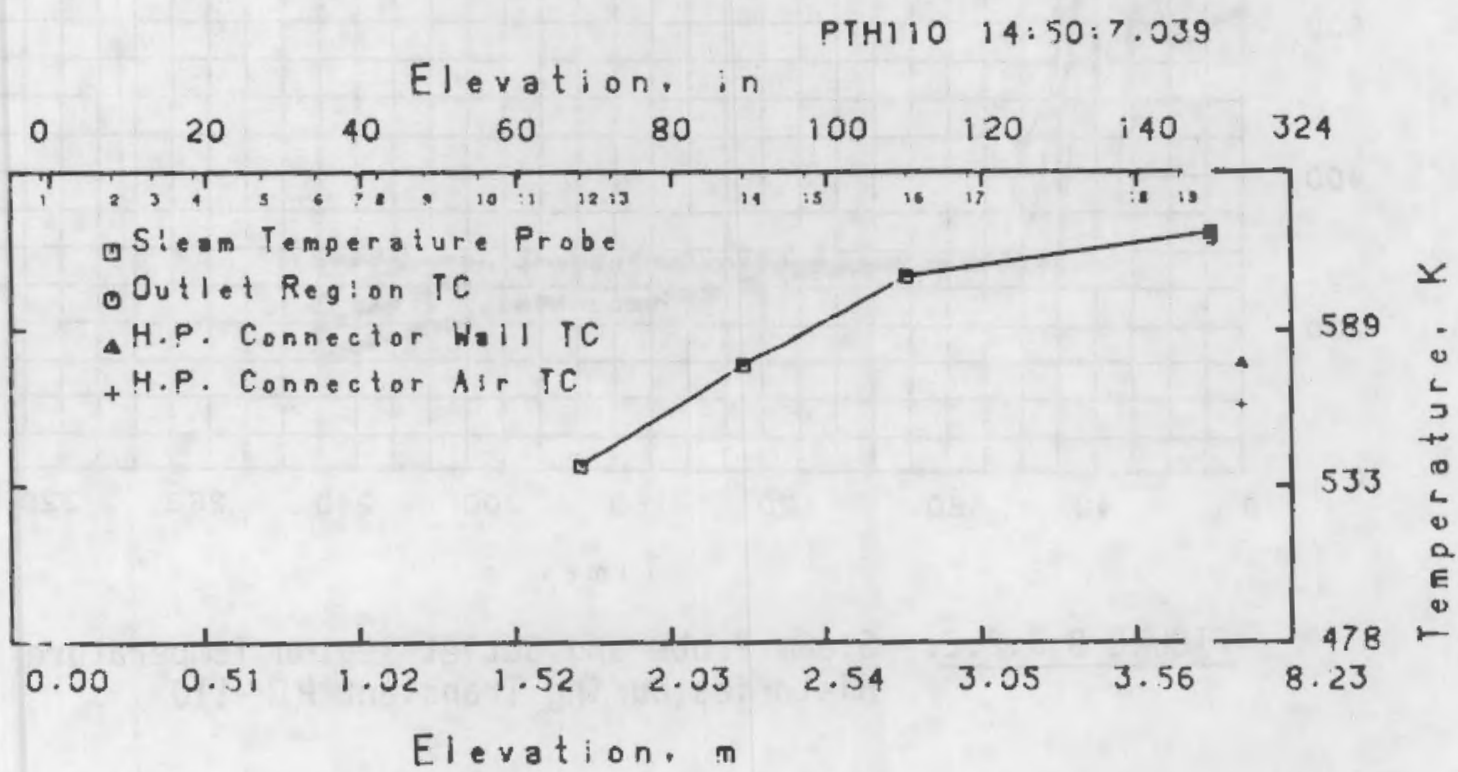

FIGURE B.3.2.1. Steam Probe and Connector Temperature Profile (In Steam, During Pretransient) 


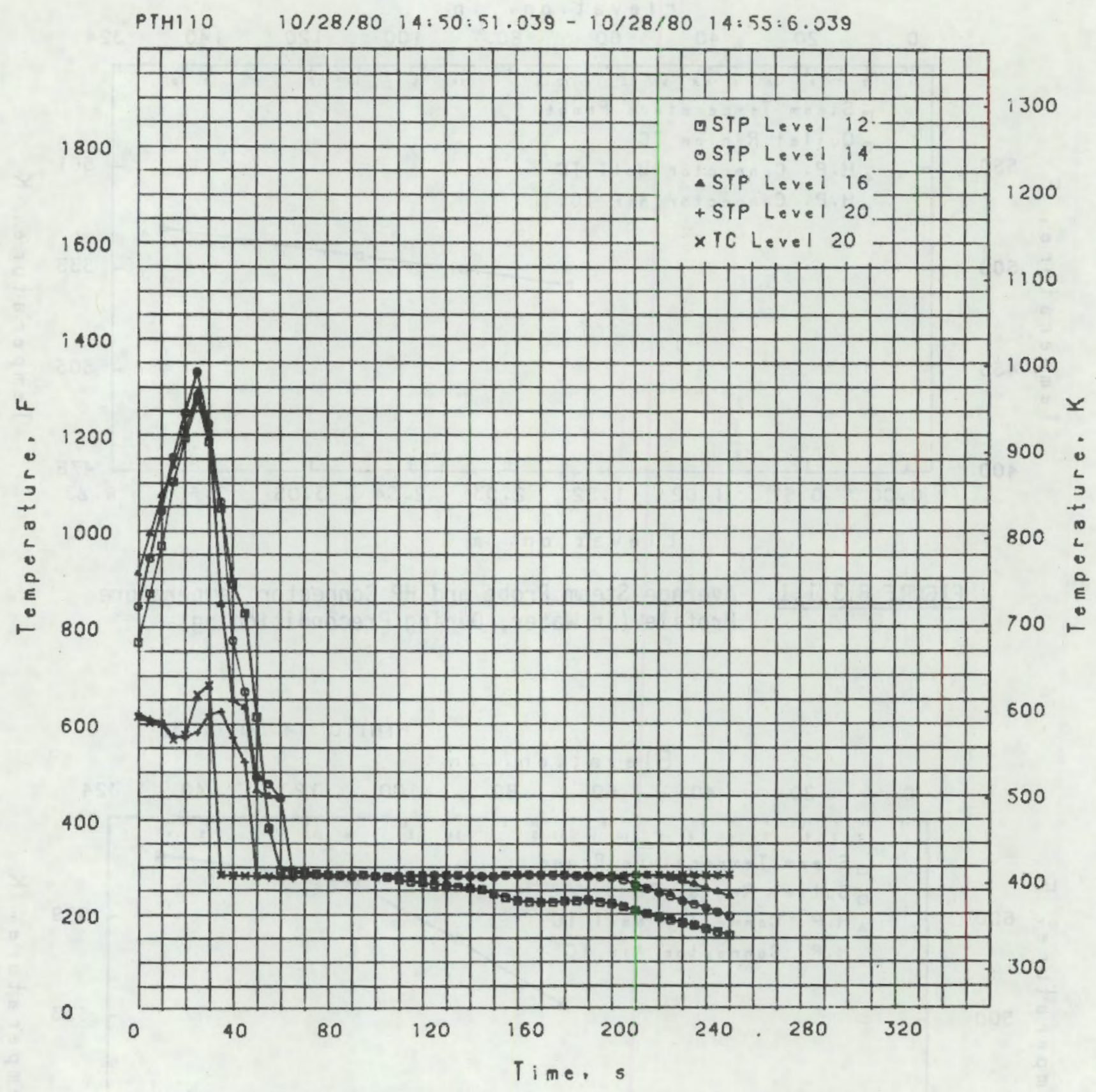

FIGURE B.3.2.2. Steam Probe and Outlet Region Temperature Histories During Transient PTH-110 
SECTION 4

FLOW TEST REFLOOD DATA 


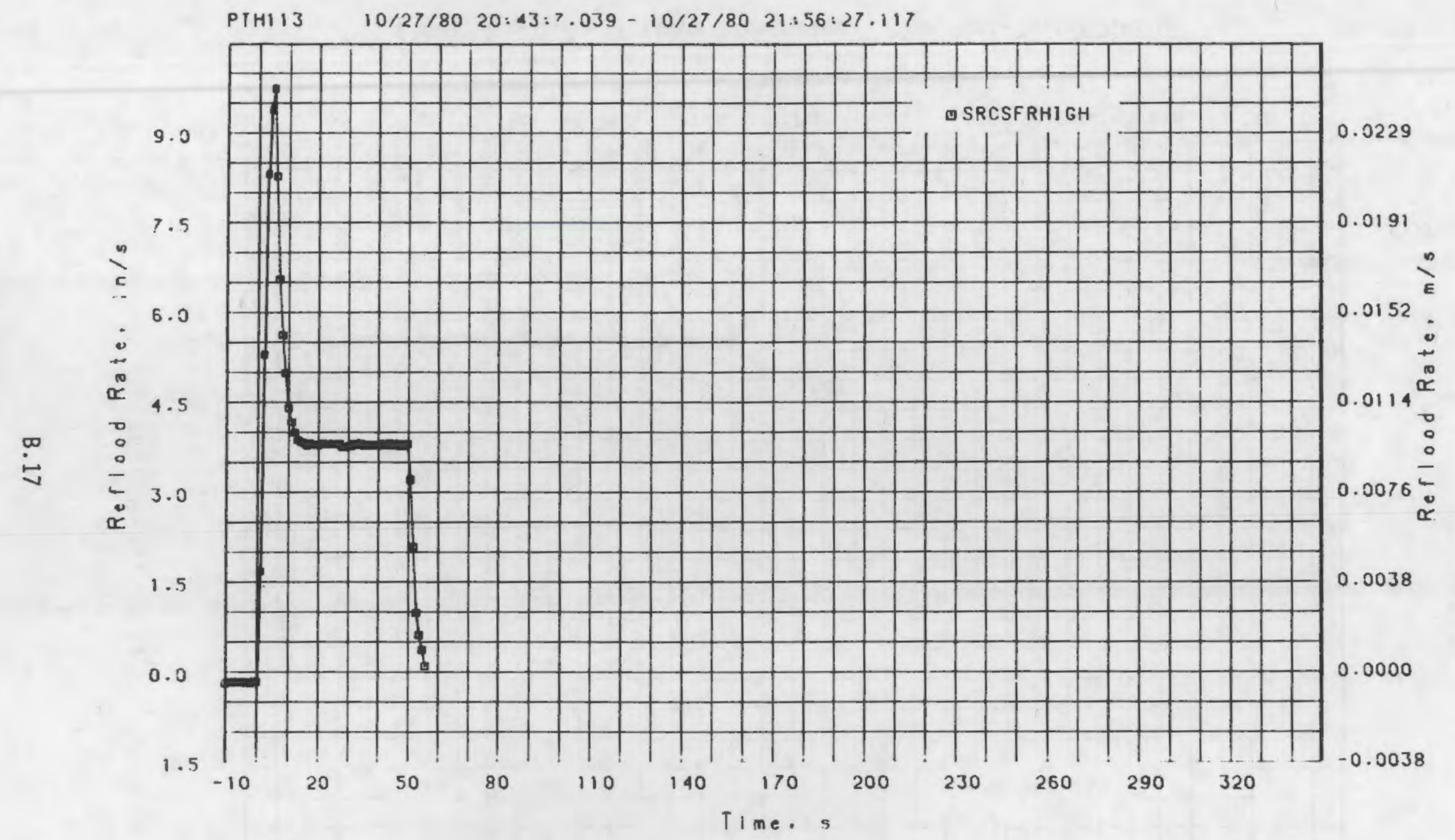

FIGURE B.4.1.1. Turbine Flow Meter. Flow Pretest PTH-110 


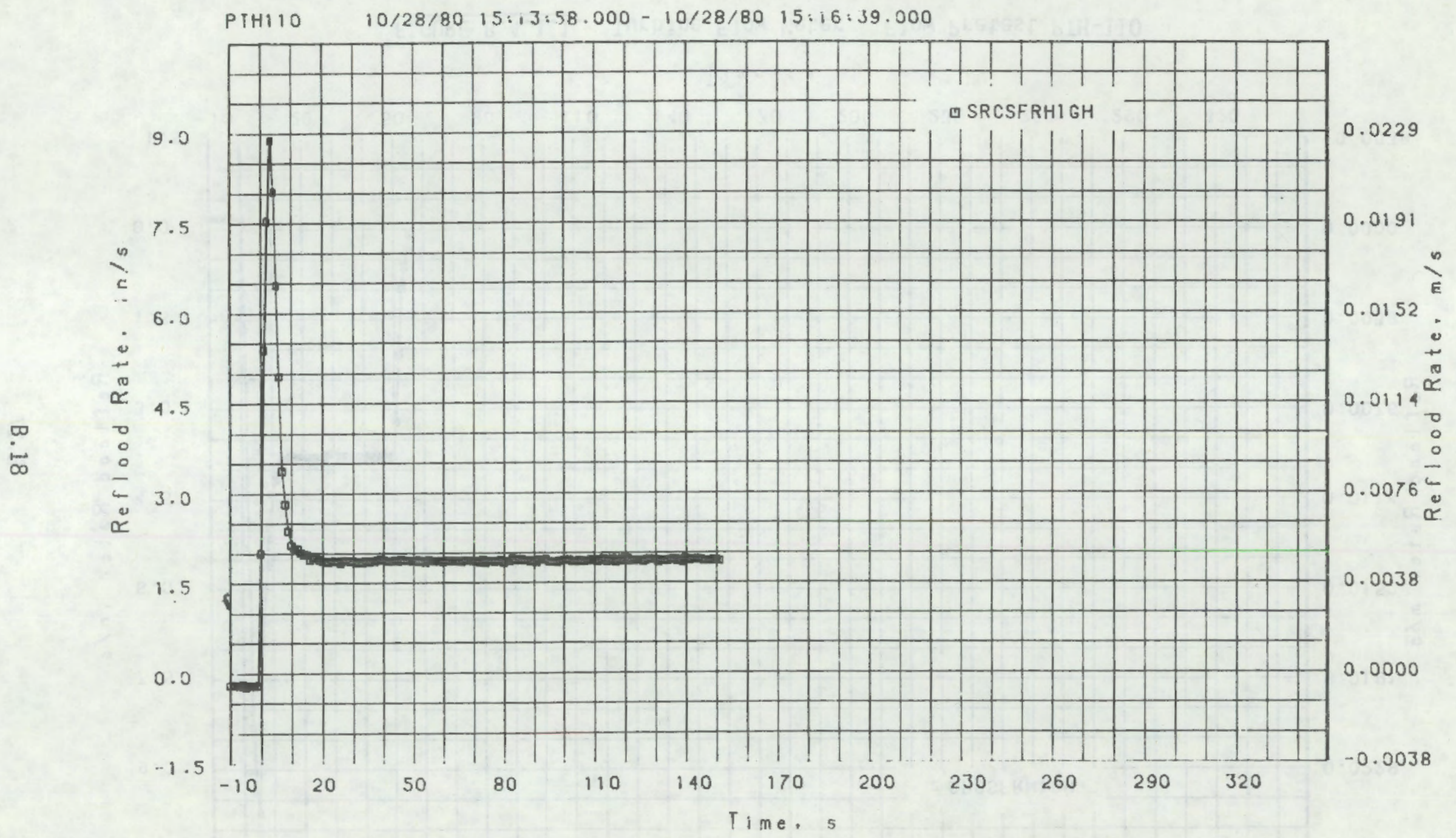

FIGURE B.4.1.2. Turbine Flow Meter. Flow Post-Test PTH-110 


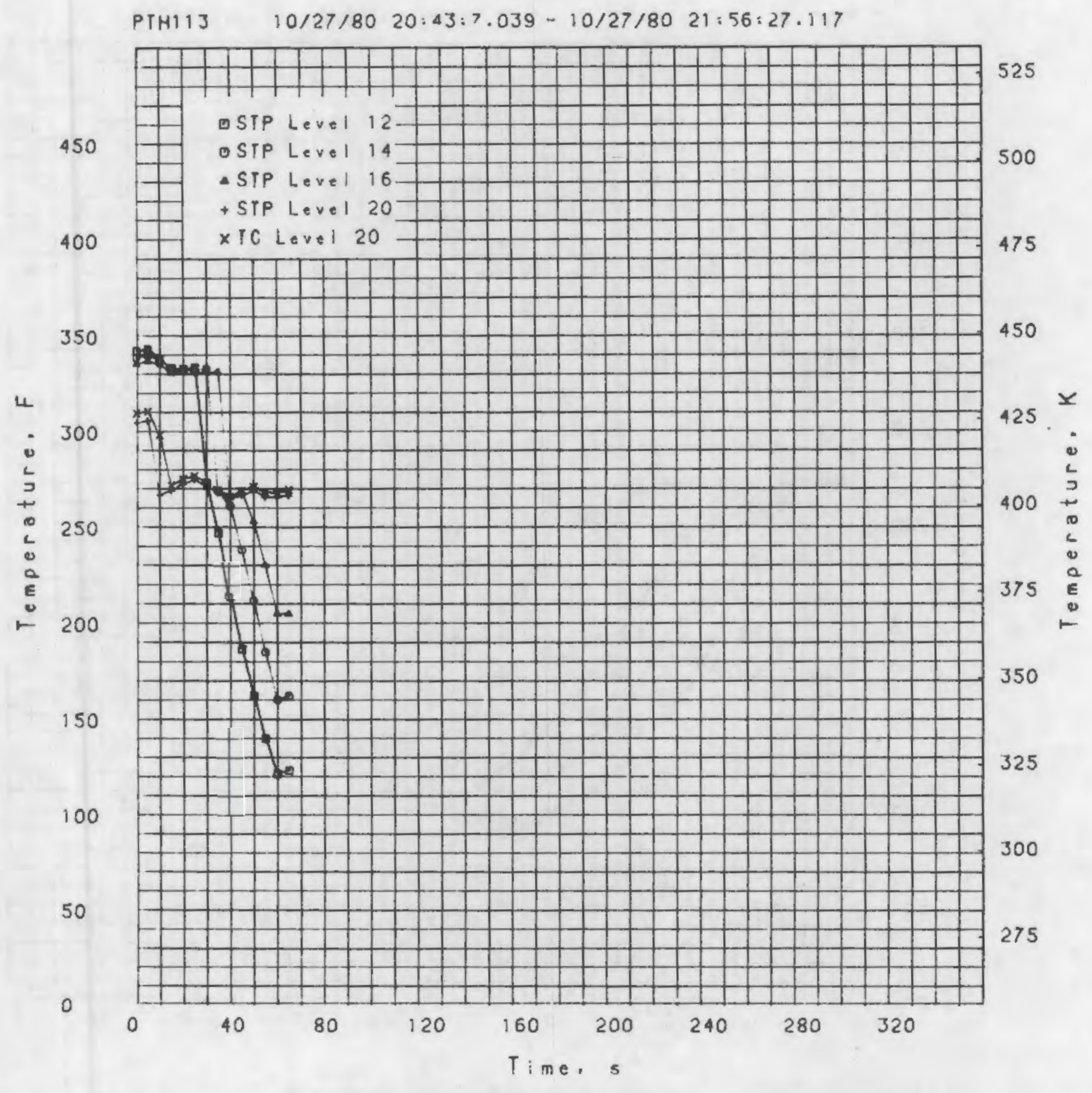

FIGURE B.4.2.1. Steam Probe Temperatures from Grid Spacers. Flow Pretest PTH-110 


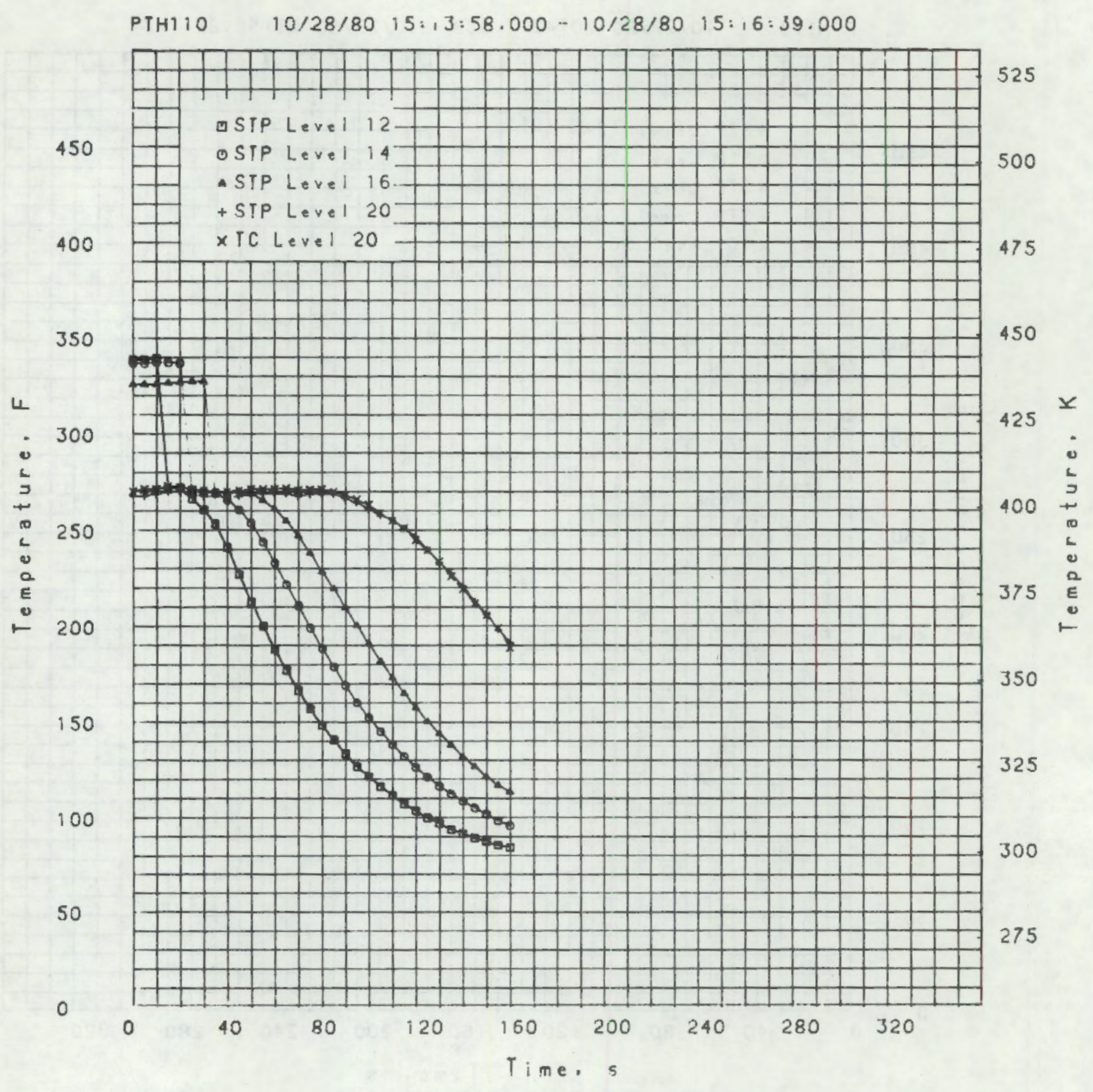

FIGURE B.4.2.2. Steam Probe Temperatures from Grid Spacers. Flow Post-Test PTH-110 


\section{SECTION 5}

PTH TRANSIENT REFLOOD DATA 


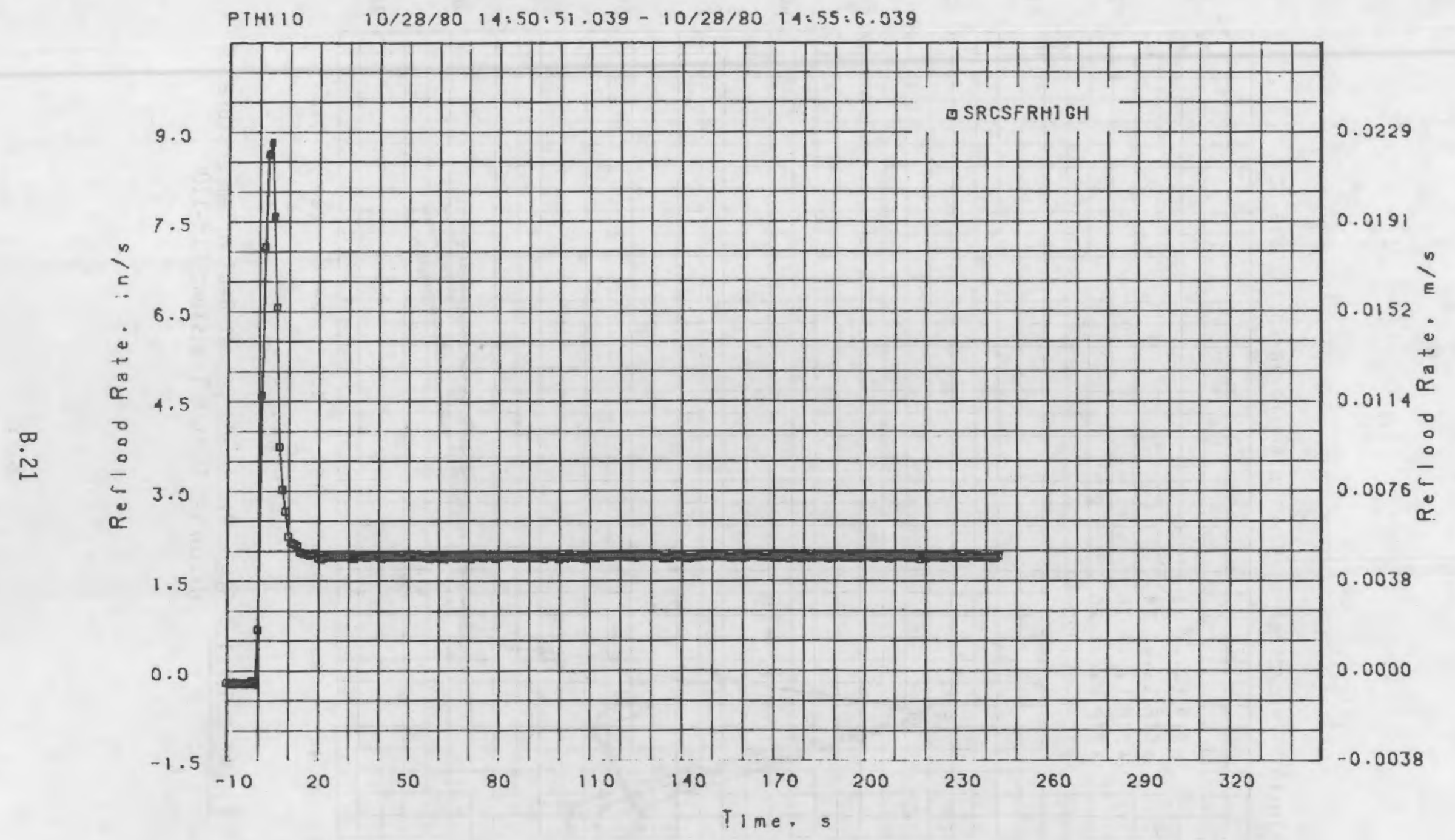

FIGURE B.5.1.1. Test Assembly Reflooding Rate--PTH-110 
PTH110 $10 / 28 / 80 \quad 14: 50: 21.039-10 / 28 / 80 \quad 14: 55: 6.039$

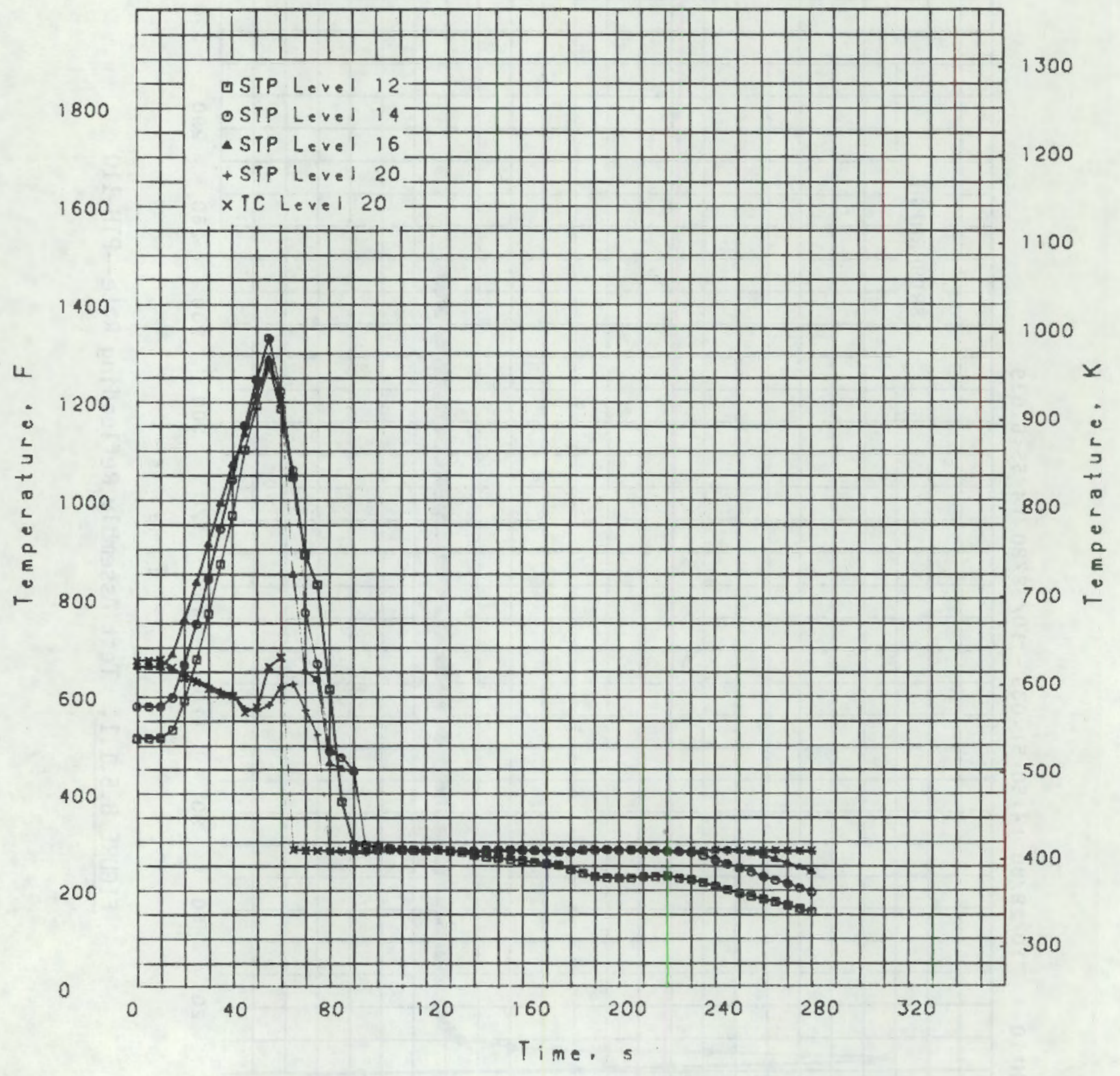

FIGURE B.5.2.1. Steam Probe and Outlet Region Temperature Histories During Transient PTH-110 


\section{APPENDIX C}

\section{MT-1 DIMENSIONAL DERM RESULTS}




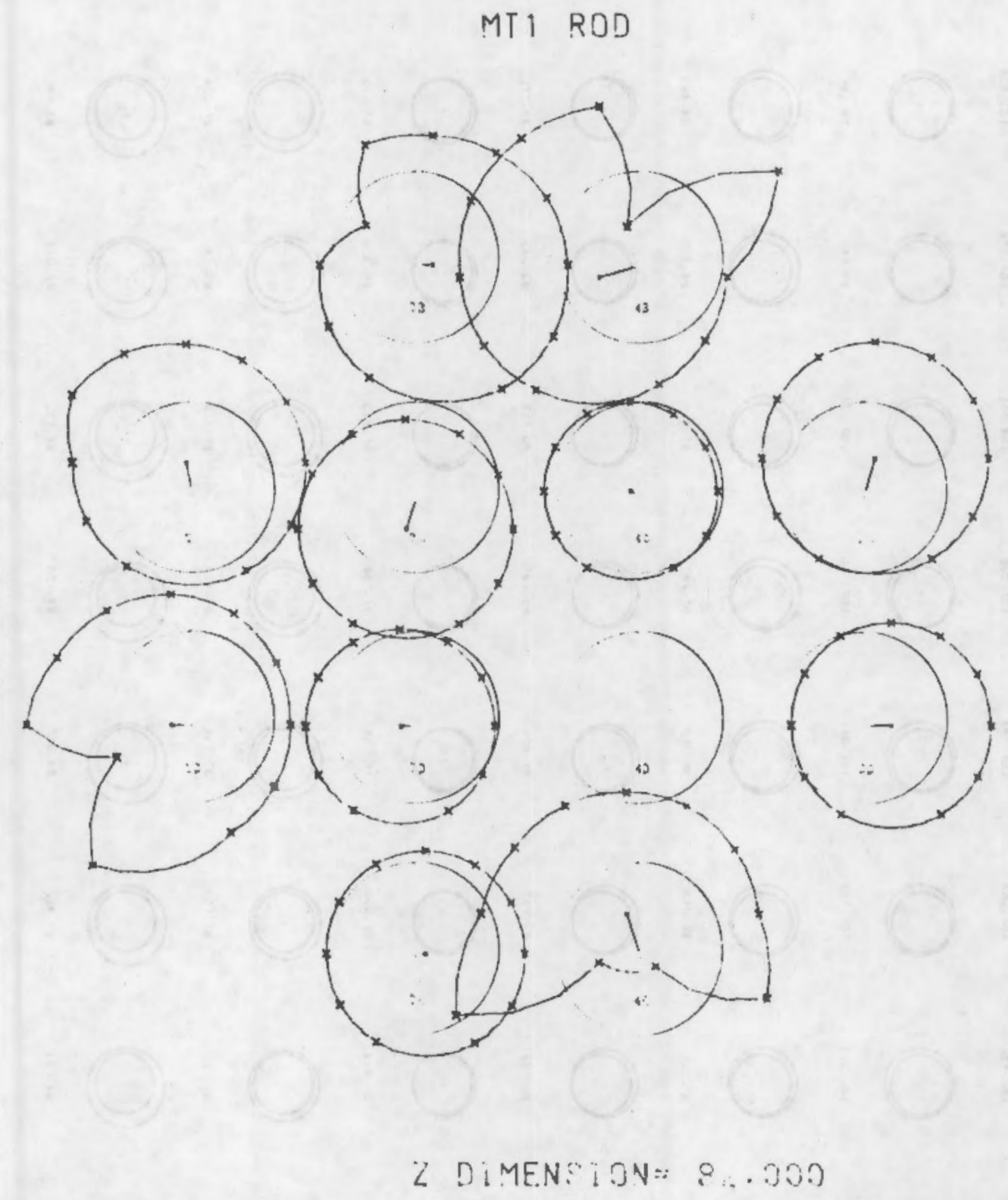

FIGURE C.1. Assembly of Single Rod Dimensions, Uncorrected for Neighbor Rods at 82.0 in. Above Bottom of Fuel Column 

$\bigcirc$
$\circ \bigcirc$
$\circ \bigcirc$
$\odot$
○
○
○
()
109.49
10.' 36
106.264
105.93
105. 322
$104.95:$
104.3?
103.029
() 0
()
()
O
()
○)
O
0

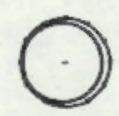
$10343: \quad 10 \%$
102.494
106.323
101.852
101.28.
100.r:0
100.35
99
- 0

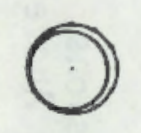
○)
○)
○)
(1)
○)
○
○ 0
○
○
○
○
O
○
O
○
$04.3: 2$
e...9
*a: i2:
๑.; a:
ง..
00.42
99. 7 :
○ 0
O
○
○
$\circ 0$
O
O
O

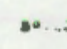
○ 0

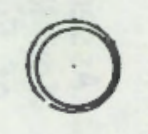
$\square$
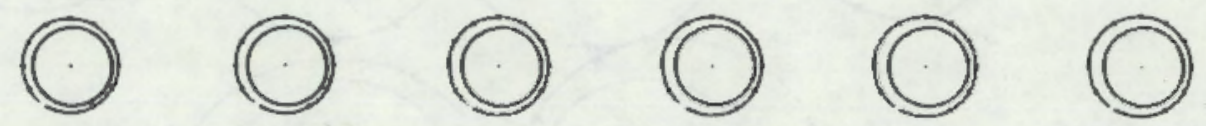

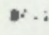
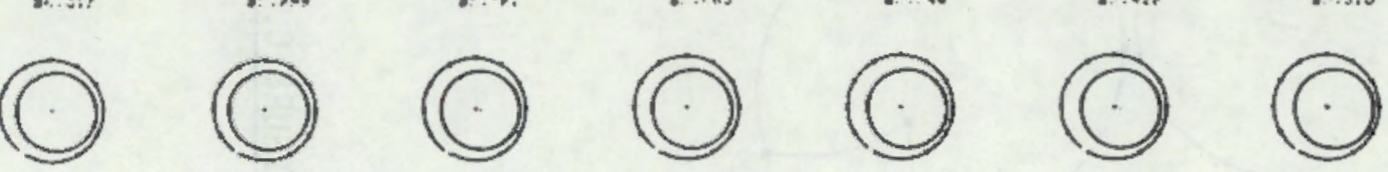
s. 9.
*.s.4
ง.e.
s4...:
(4.) 21

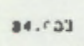
s4.495
94.35,
s4...so
s..:3.

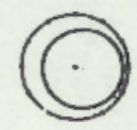
$\square$

$\stackrel{i}{i}$

FIGURE C.2.1. Dimensional Summary of Fuel Rod 202 at Axial Elevations Above the Bottom of the Fuel Column 


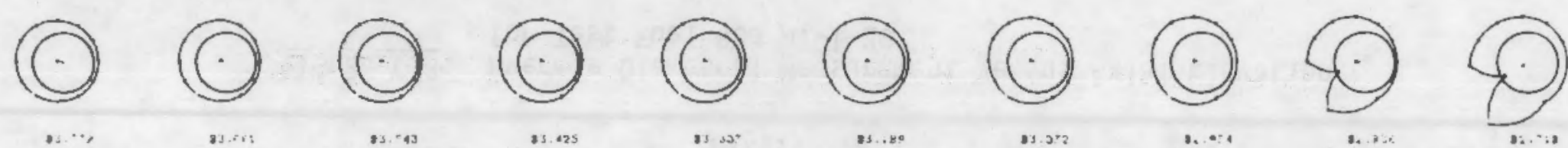

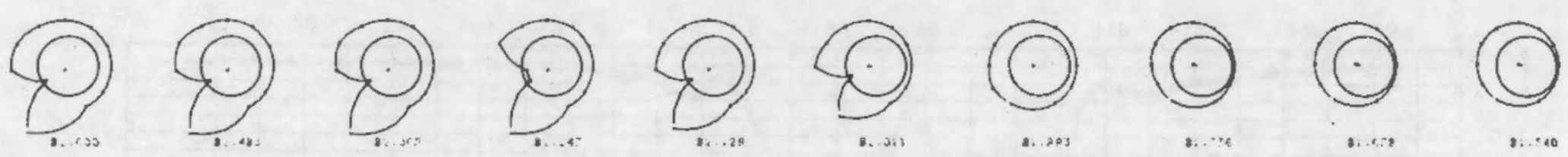

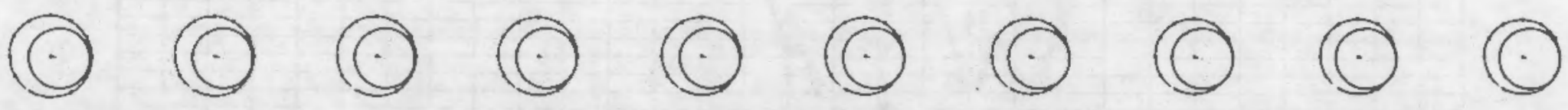

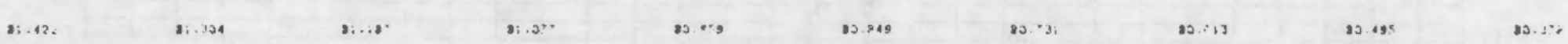

(C) (9) (9) i
2. 280
13. x.4
ta. ase
79.20
79.33
19.03:
7?.si?
$19 . .23$
(O)

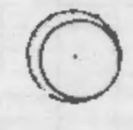
(1)

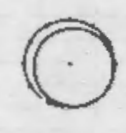
O
O
O
O
O
O
○
O
O
○
O
O
○
O
O
$\bigcirc$
O
○

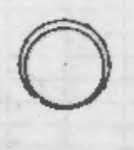
O
○

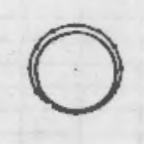
O

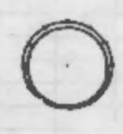
○

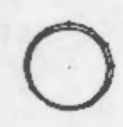

FIGURE C.2.2. Dimensional Surmary of Fuel Rod 202 at Axial Elevations Above the Bottom of the Fuel Column 


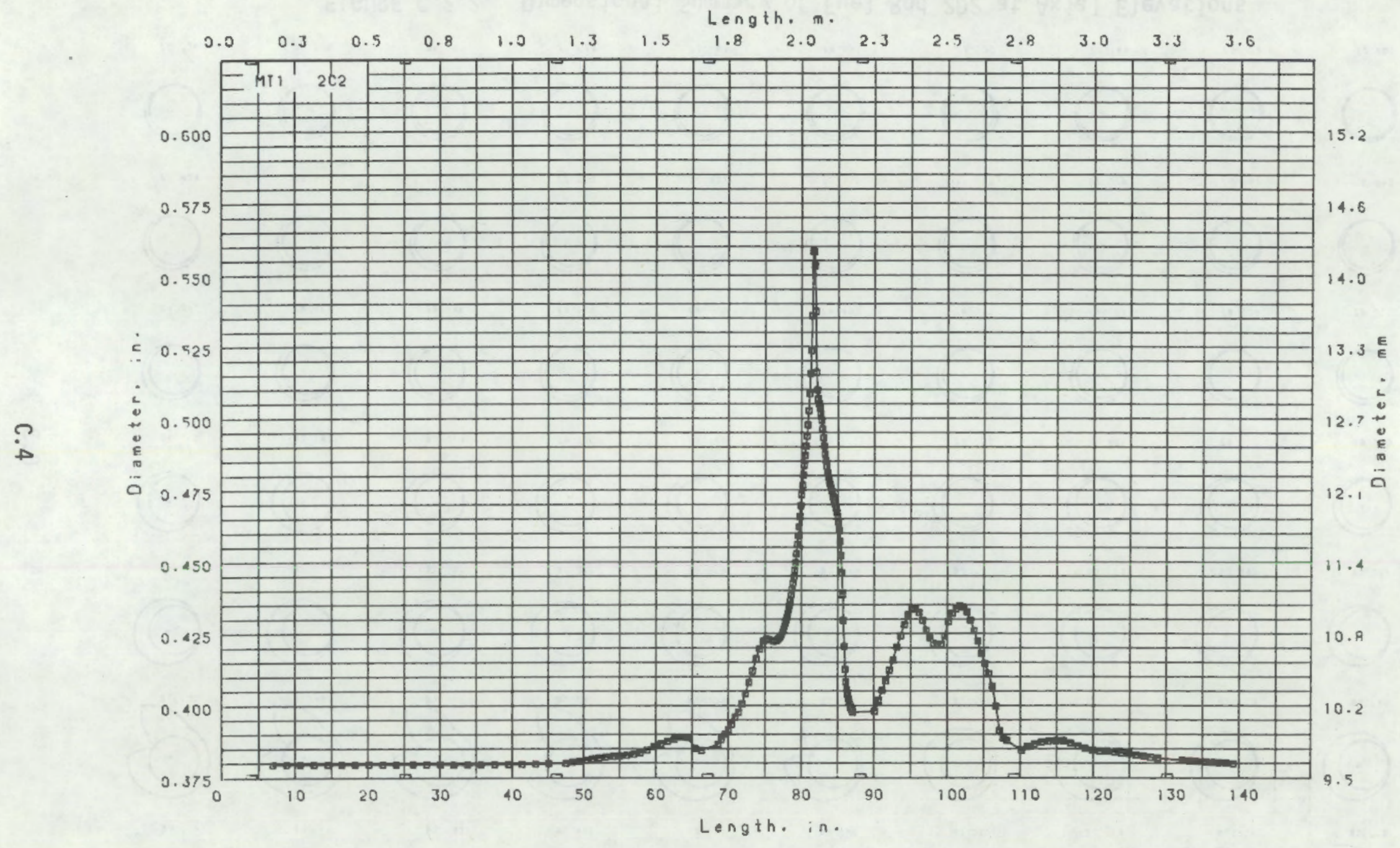

FIGURE C.3. Average Diametral Measurement Versus Axial Elevation for Test Fuel Rod MT-1-2C 


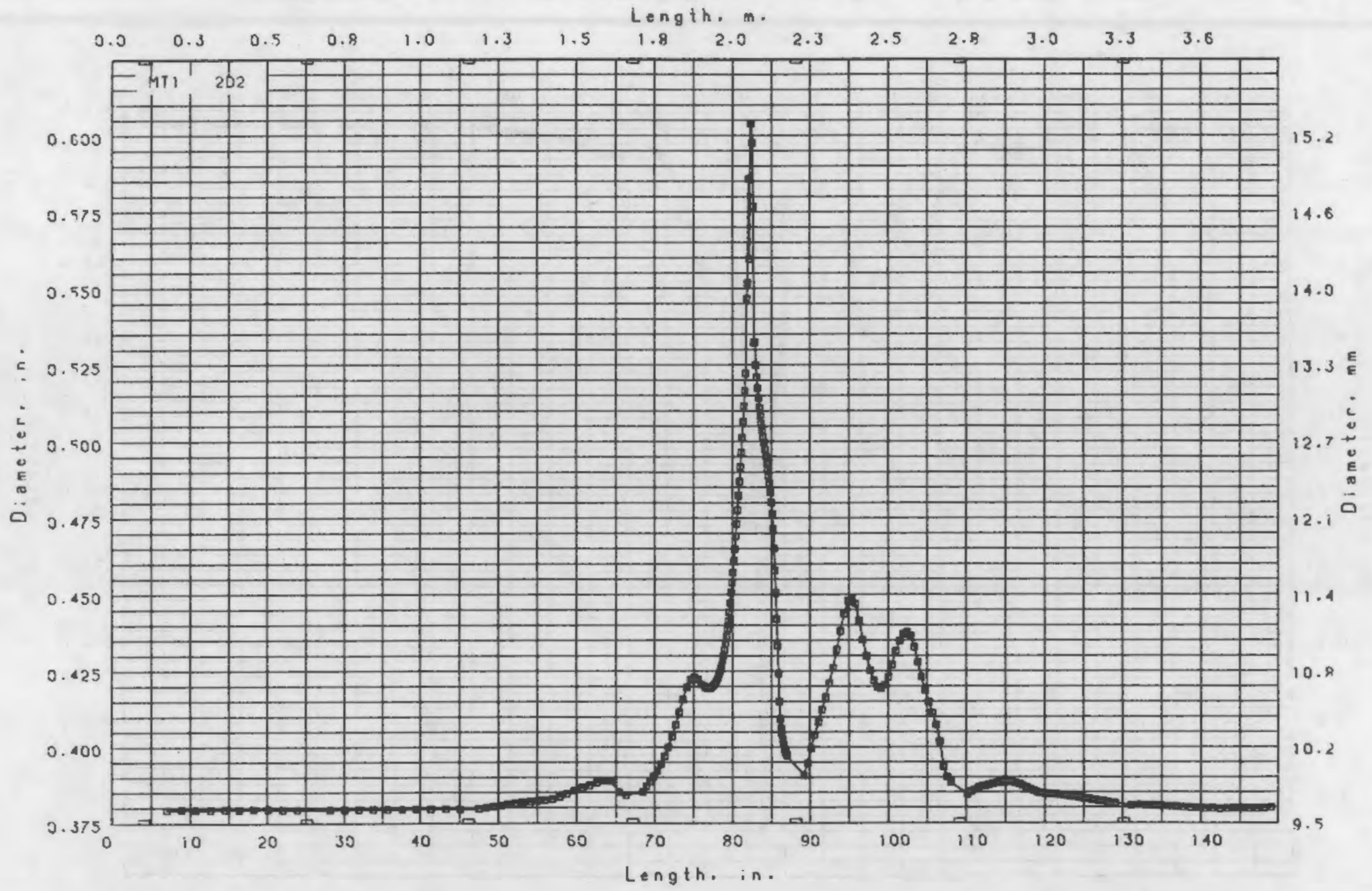

FIGURE C.4. Average Diametral Measurement Versus Axial Elevation for Test Fuel Rod MT-1-2D 


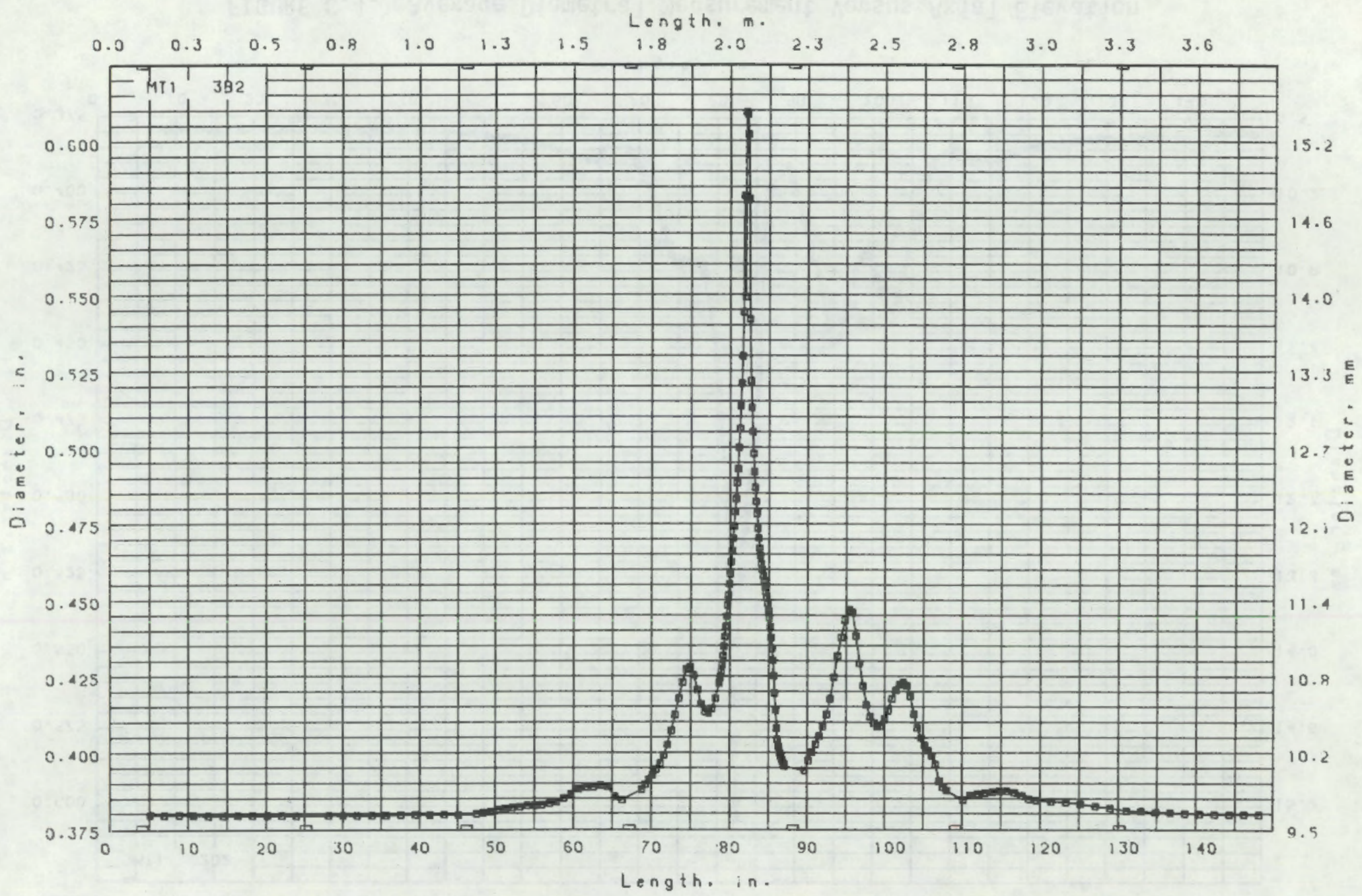

FIGURE C.5. Average Diametral Measurement Versus Axial Elevation

for Test Fuel Rod MT-1-3B 


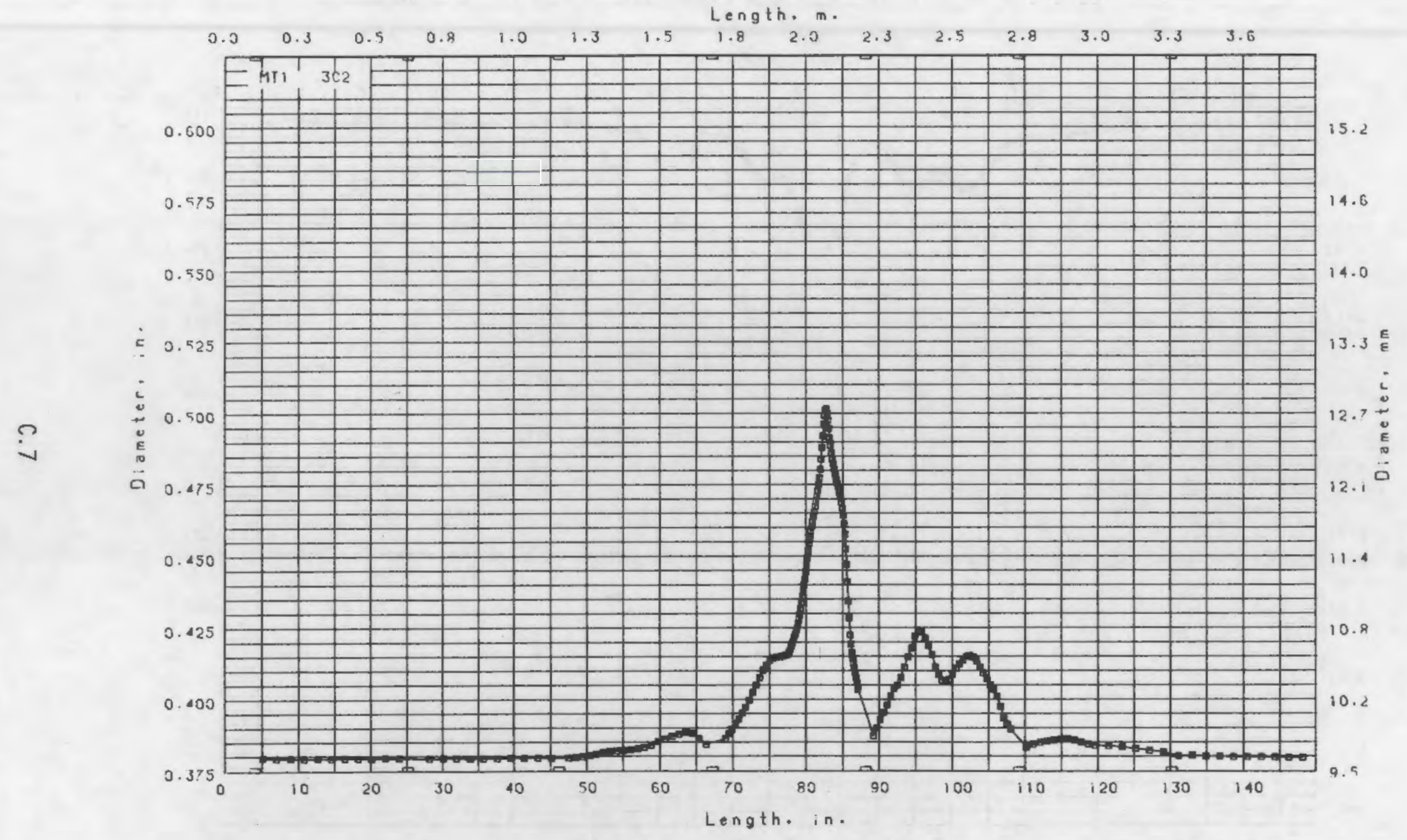

FIGURE C.6. Average Diametral Measurement Versus Axial Elevation for Test Fuel Rod MT-1-3C 


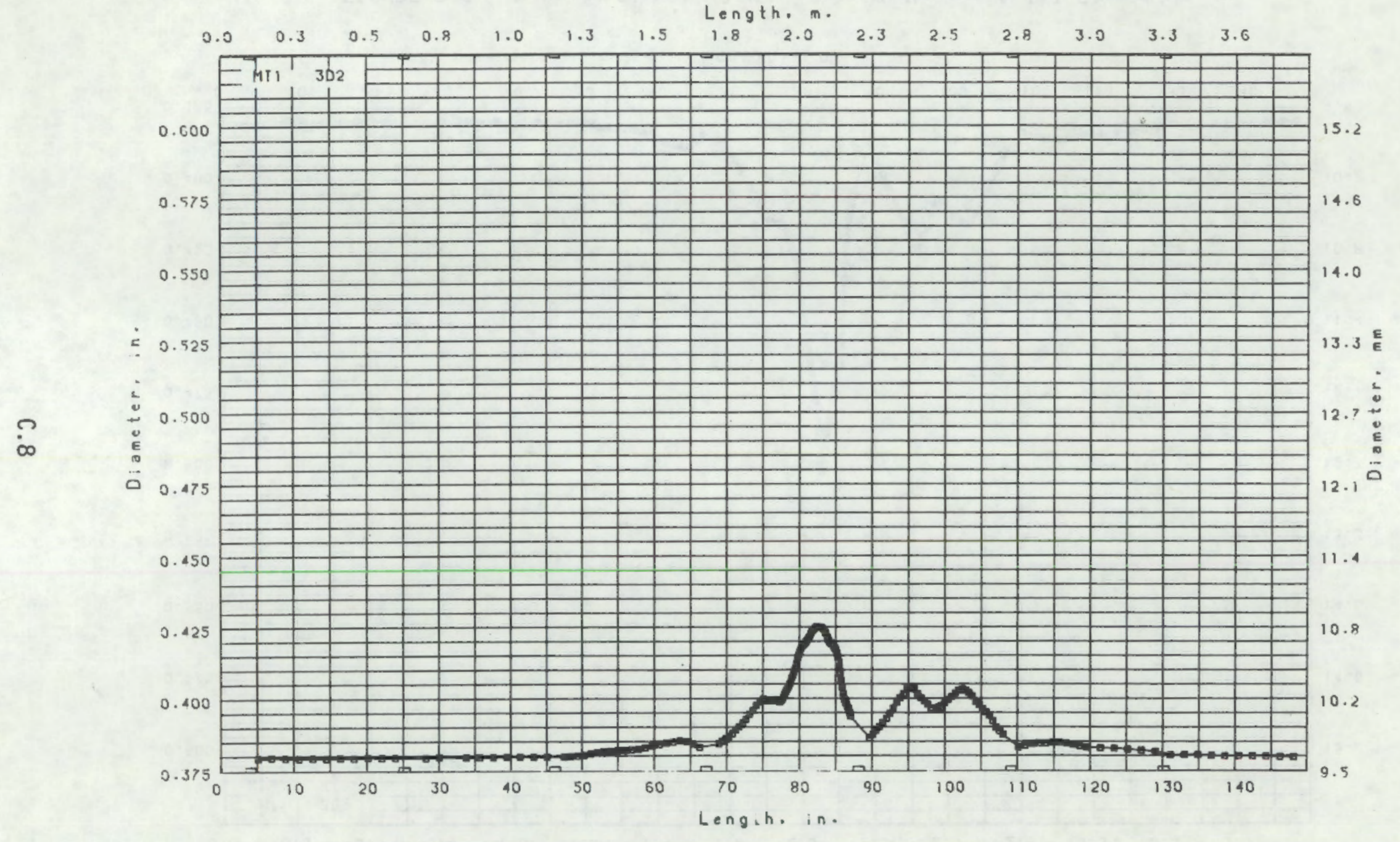

FIGURE C.7. Average Diametral Measurement Versus Axial Elevation for Test Fuel Rod MT-1-3D 


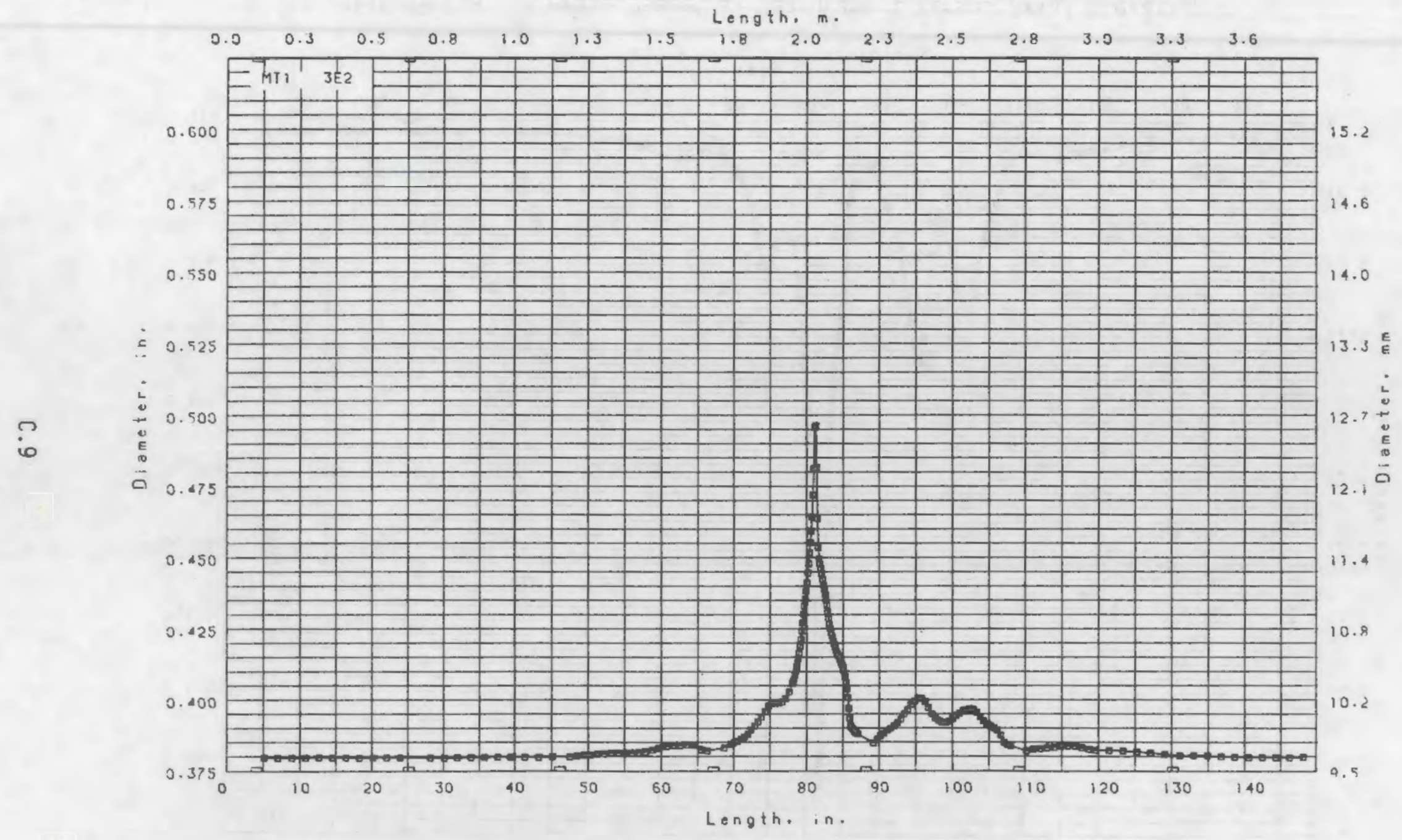

FIGURE C.8. Average Diametral Measurement Versus Axial Elevation for Test Fuel Rod MT-1-3E 


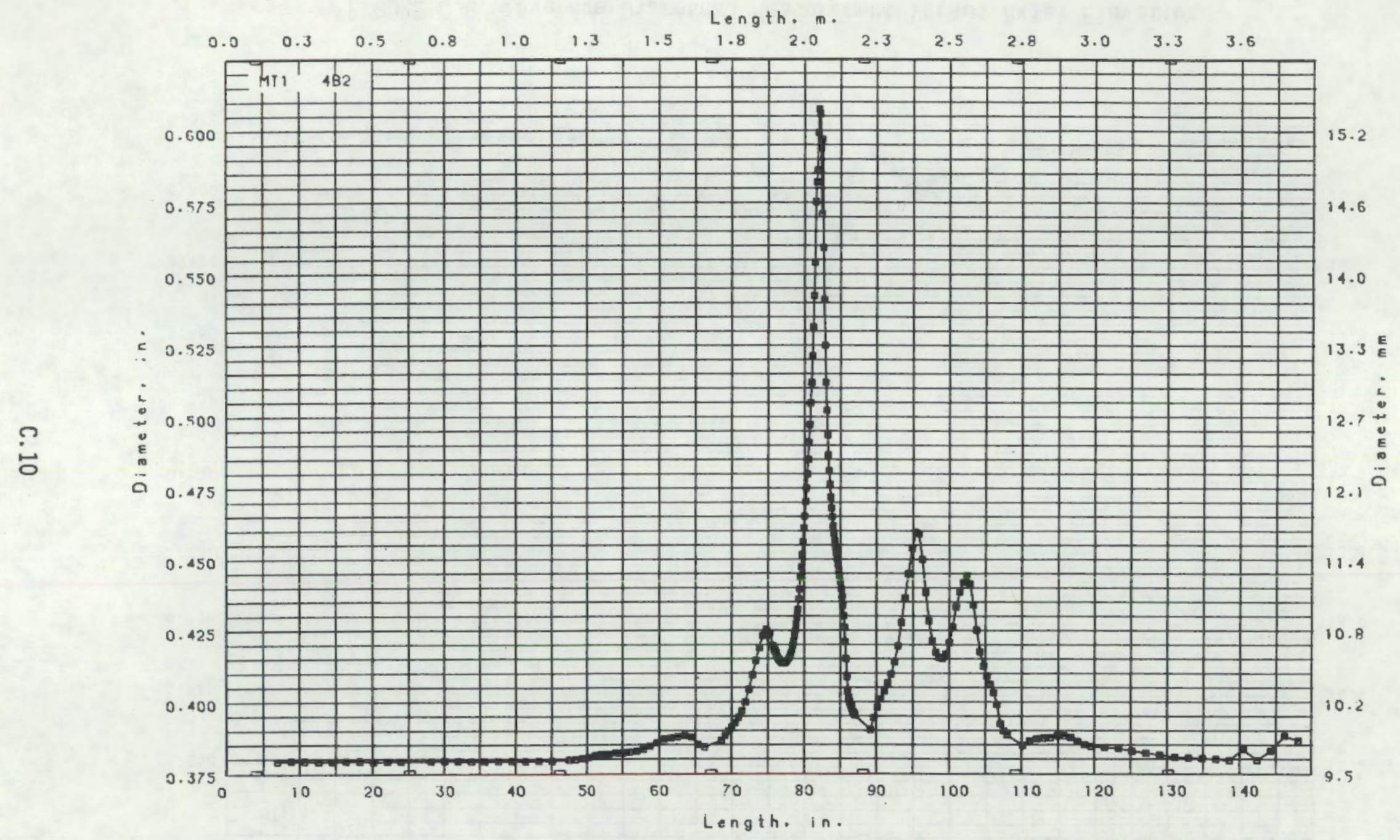

FIGURE C.9. Average Diametral Measurement Versus Axial Elevation

for Test Fuel Rod MT-1-4B 


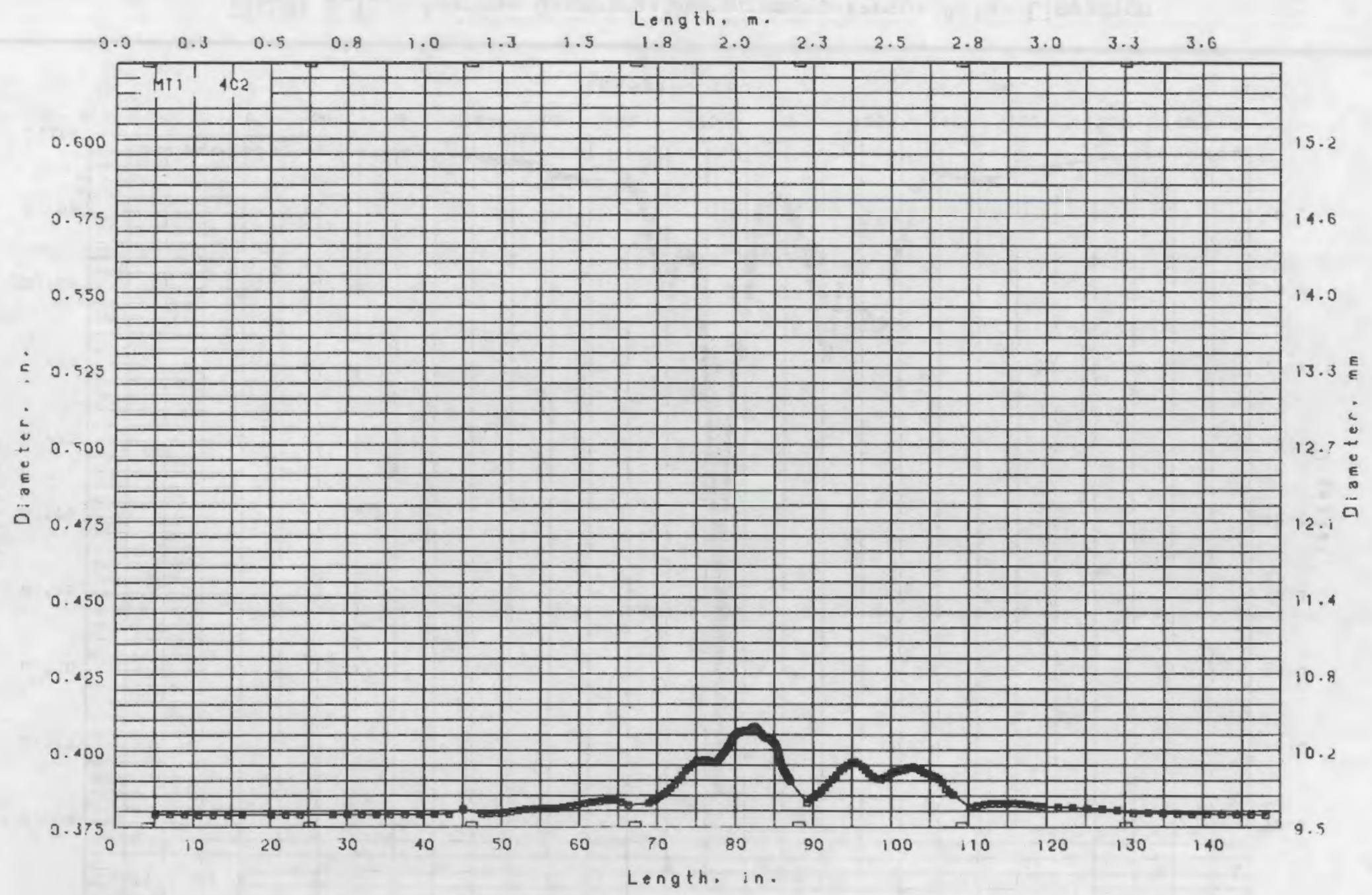

FIGURE C.10. Average Diametral Measurement Versus Axial Elevation for Test Fuel Rod MT-1-4C 


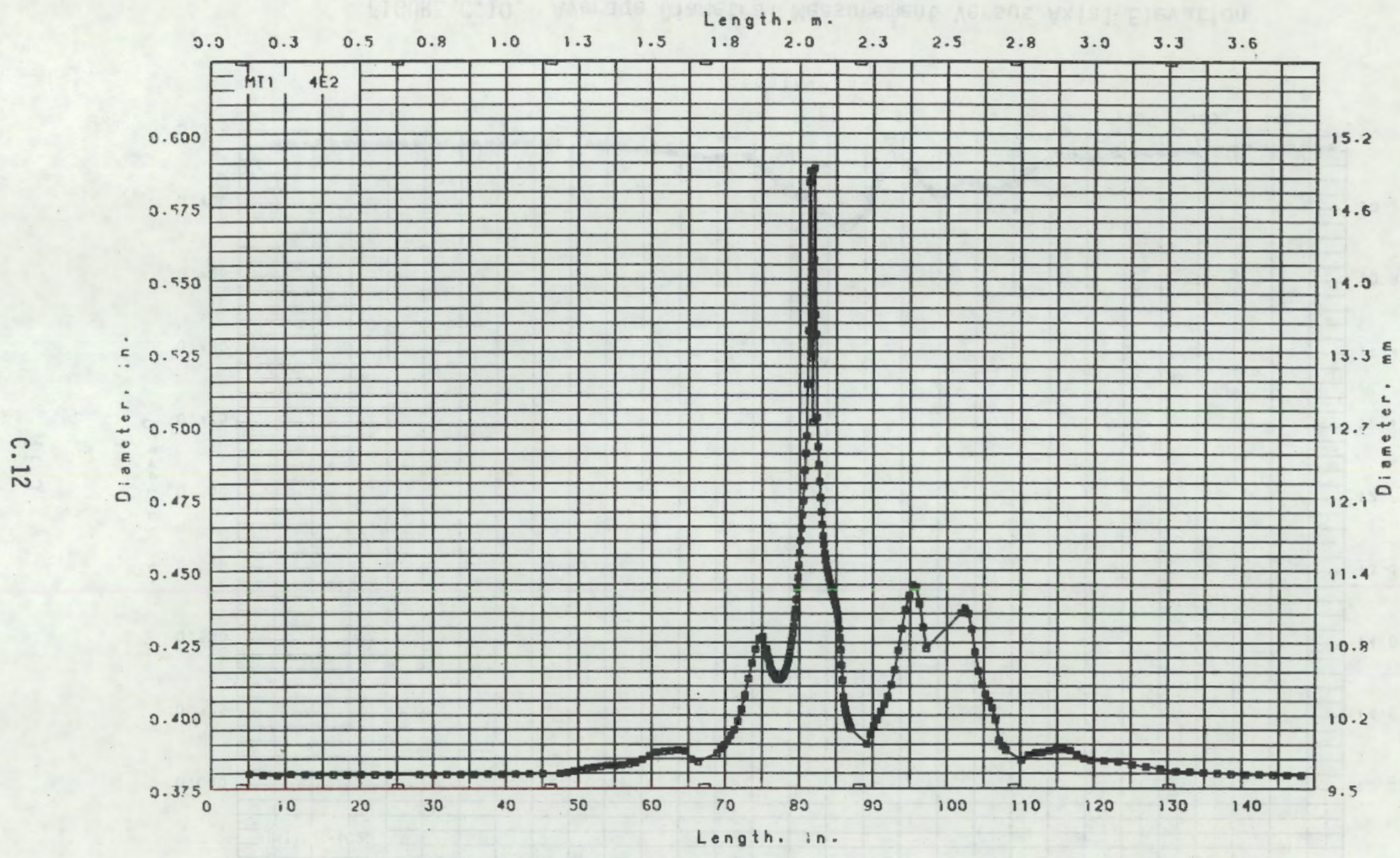

FIGURE C.11. Average Diametral Measurement Versus Axial Elevation for Test Fuel Rod MT-1-4E 


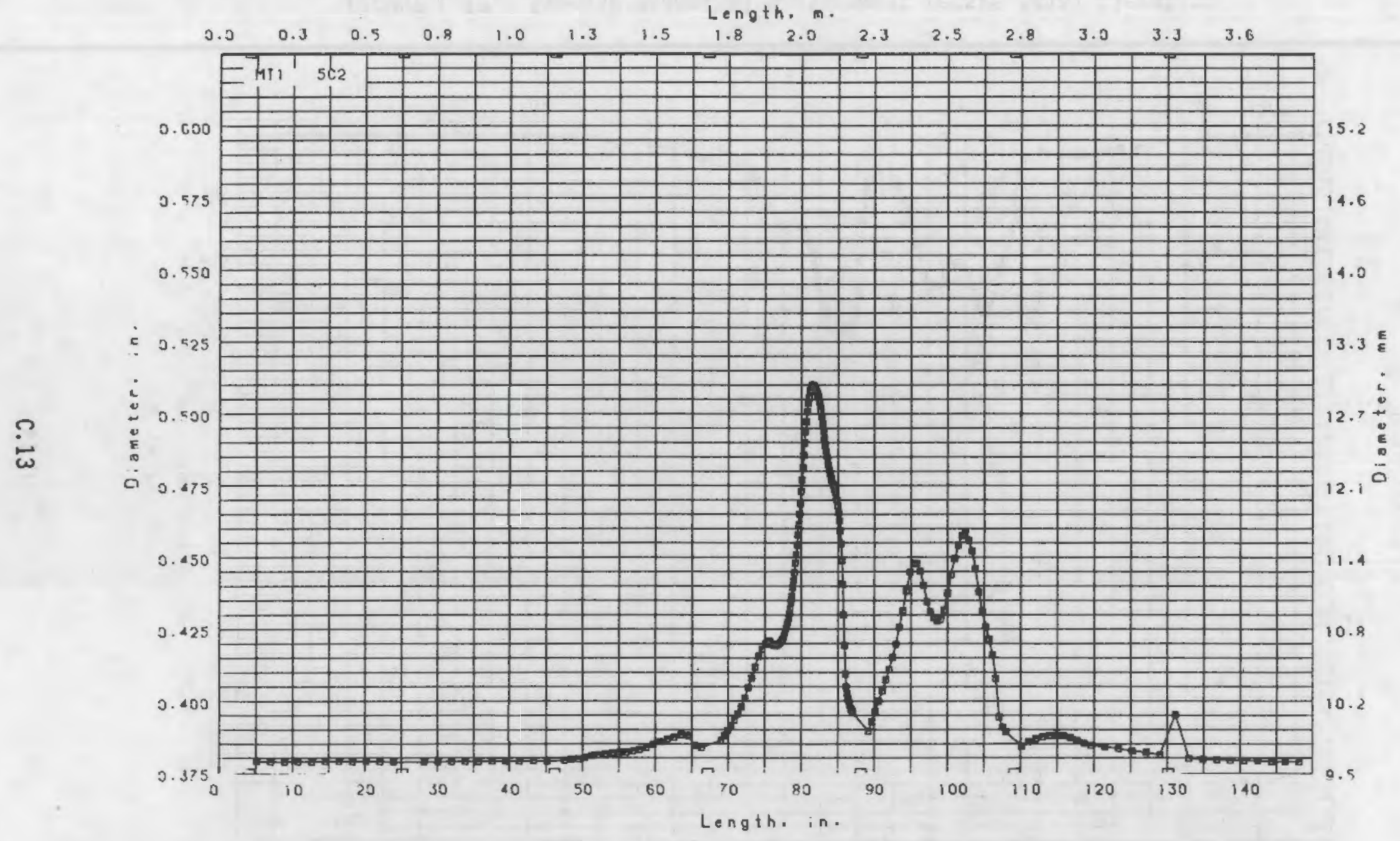

FIGURE C.12. Average Diametral Measurement Versus Axial Elevation for Test Fuel Rod MT-1-5C 


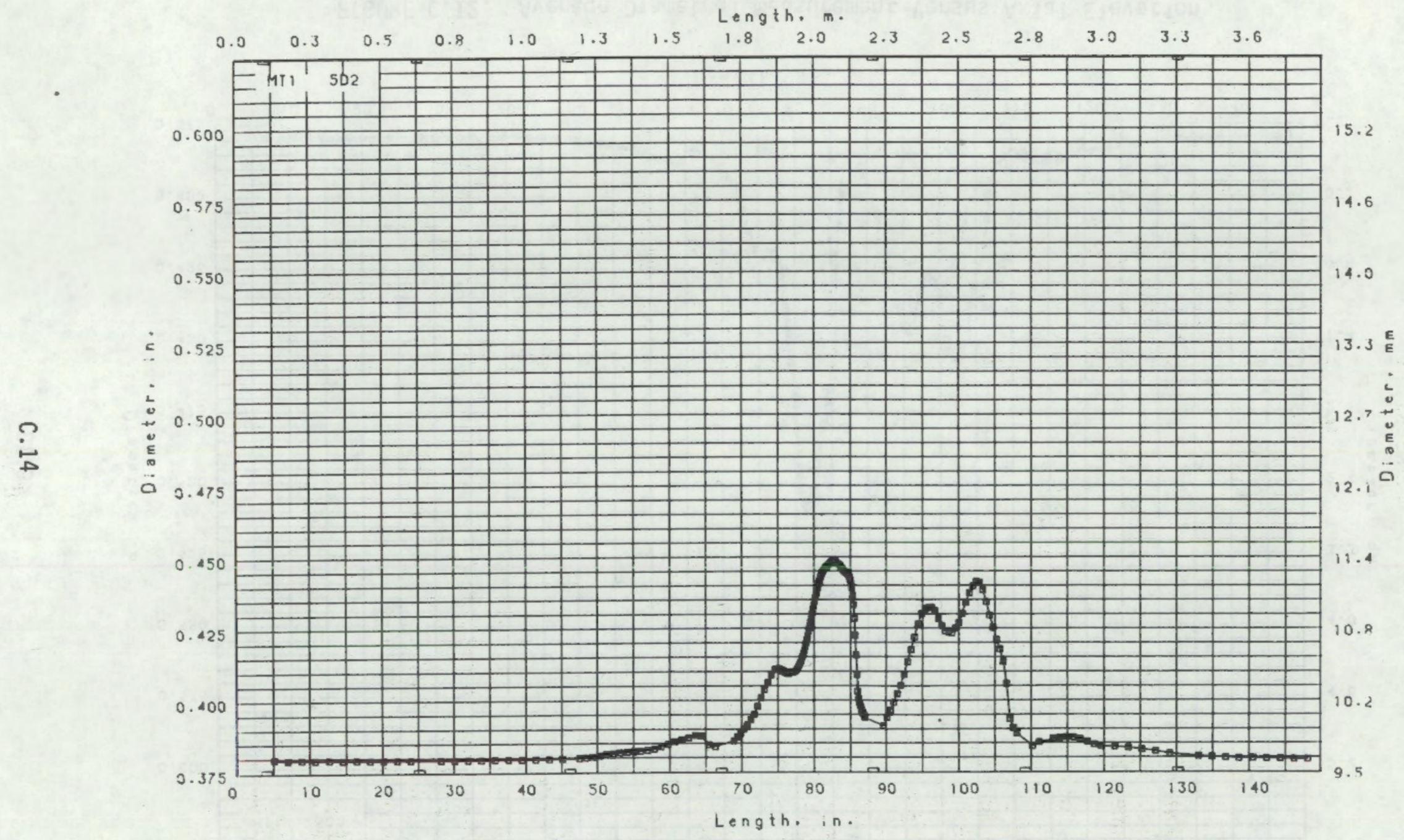

FIGURE C.13. Average Diametral Measurement Versus Axial Elevation for Test Fuel Rod MT-1-5D 
No. of

Copies

OFFSITE

A. A. Churm

DOE Patent Division

9800 S. Cass Avenue

Argonne, IL 60439

400 U.S. Nuclear Regulatory Commission Division of Technical Information and Document Control

7920 Norfolk Avenue

Bethesda, MD 20014

2 DOE Technical Information Center

\section{J. Davis}

Nuclear Engineering Department

Potomac Electric Avenue NW

Washington, DC 20068

8 Chalk River Nuclear Laboratories

Atomic Energy of Canada, Ltd.

Chalk River, Ontario, Canada

KOJ 1J0

C. A. Herriot (6)

D. T. Nishimura

M. Notley

P. Griffith

Massachusetts Institute of Technology

Department of Nuclear Engineering Cambridge, MA 02139

W. Kirchner

Los Alamos Scientific Laboratory

P. 0. Box 1663

Los Alamos, NM 87544
No. of

Copies

J. Gittus

Springfields Nuclear Power Development Laboratory

United Kingdom Atomic Energy Authority

Springfields, Salwick

Preston PR 4 ORR

Engl and

Mr. Mann

Springfields Nuclear Power Development Laboratory

United Kingdom Atomic Energy Authority

Springfields, Salwick

Preston PR 4 ORR

Engl and

4 Kerforschungzentrum Karlsruhe Weberstrasse 5

$75 \mathrm{Kar}$ lsruhe 1

Federal Republic of Germany

H. Rininsl andd (2)

A. Fiege

F. Erbacher

4 JRC-ISPRA

EURATOM

CCR ESSOR Division

21020 Cento Euratom Di Ispra (Varese)

Italy

T. Doyle

R. Klersy

J. Randles

S. Finzi 
No. of

Copies

2 Central Electricity Generating Board

Berkeley Nuclear Laboratories

Berkeley, Gloucestershire GL13 9PB

Engl and

T. Healey

4 M. Ishikawa, Chief

Reactivity Accident Laboratory

Japan Atomic Energy Research Institute

Tokai Research Establishment

Tokai-Mura, Naka-Gun

Ibaraki-Ken

Japan

D. M. Chapin

MPR Associates, Inc.

1140 Connecticut Avenue, NW

Washington, OC 20036

0. Ogden

EG\&G Idaho, Inc.

P. 0. Box 1625

Idaho Falls, I0 83401

2 Combustion Engineering 1000 Prospect Hill Road

P. 0. Box 500

Windsor, CT 06095

R. Duncan

S. Ritterbush

2 Babcock and Wilcox

P. 0. Box 1200

Lynchburg, VA 24505

C. Morgan

B. Bingham
No. of

Copies

5 General Electric Company

175 Curtner Avenue

San Jose, CA 95114

S. Armijo

R. Williams

L. Noble

G. Sozzi

N. Shirley

4 Exxon Nuclear, Inc. 2101 Horn Rapids Road

Richland, WA 99352

W. Nechodom

W. Kayser

T. Doyle

J. Morgan

3 U.S. Nuclear Regulatory

Commission

Advisory Committee on Reactor Saf eguards

Washington, DC 20555

Mail Stop $\mathrm{H}-1016$

P. Boehnert

P. Shewmon

D. Okrent

U.S. Nuclear Regulatory

Commission

Washington, OC 20555

Mail Stop

L. Shotkin

M/S 1130-SS

N. Zuber

M/S 1130-SS

R. Meyer

R. Van Houten (3)

$M / S$ P-1114

G. Marino

M/S 1130-SS

G. McPherson

M/S 1130-SS

M/S 1130-SS

J. Norberg

M/S NL-5650

N. Lauben

M/S P-1132

W. Hodges

$M / S P-1132$

L. Phillips

M/S P-1114

A. Hon

M/S 1130-SS

Y. Hsu

M/S 1130-SS 
No. of

Copies

U.S. Nuclear Regulatory (contd) Commission

Washington, DC 20555

Mail Stop
W. Johnston
M/S P-1114
D. Power
$\mathrm{M} / \mathrm{S} \mathrm{P}-1114$
M. Pickles imer
$\mathrm{M} / \mathrm{S} 1130-\mathrm{SS}$
L. Tong
T. Murley
M/S 1130-SS
$M / S$ P-1102

6 Electric Power Research

Institute

3412 Hillview Avenue

Palo Alto, CA 94022
W. Sun
P. Davis (ITI)
L. Thompson
R. Oehlberg
G. Thomas
R. Duffey

3 Westinghouse Electric Corporation

P. 0. Box 355

Pittsburgh, PA 15230

L. Hochreiter

R. Rosal

D. Burman

3 Oak Ridge National

Laboratory

P. 0. Box X

Oak Ridge, TN 37830

F. Mynatt

R. Chapman (2)
No. of

Copies

36 Pacific Northwest Laboratory P.0. Box 999

Richland, WA 99352

C. L. Mohr

J. 0. Barner

W. J. Bailey

W. D. Bennett

B. J. Breizy

L. W. Cannon

E. L. Courtright

K. E. Davis (6)

M. D. Freshley

R. L. Goodman

C. R. Hann

G. M. Hesson

L. L. King

R. K. Marshall

P. N. McDuffie

C. Nealley

L. J. Parchen

J. P. Pilger

G. E. Russcher (3)

B. J. Webb

N. J. Wildung :

C. L. Wilson

Technical Publications (5)

Publishing Coordination (2) 


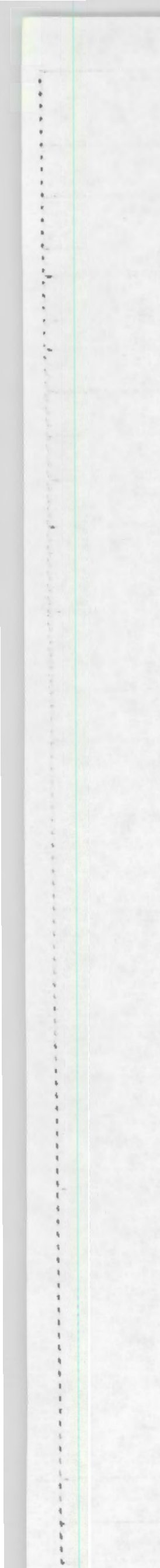




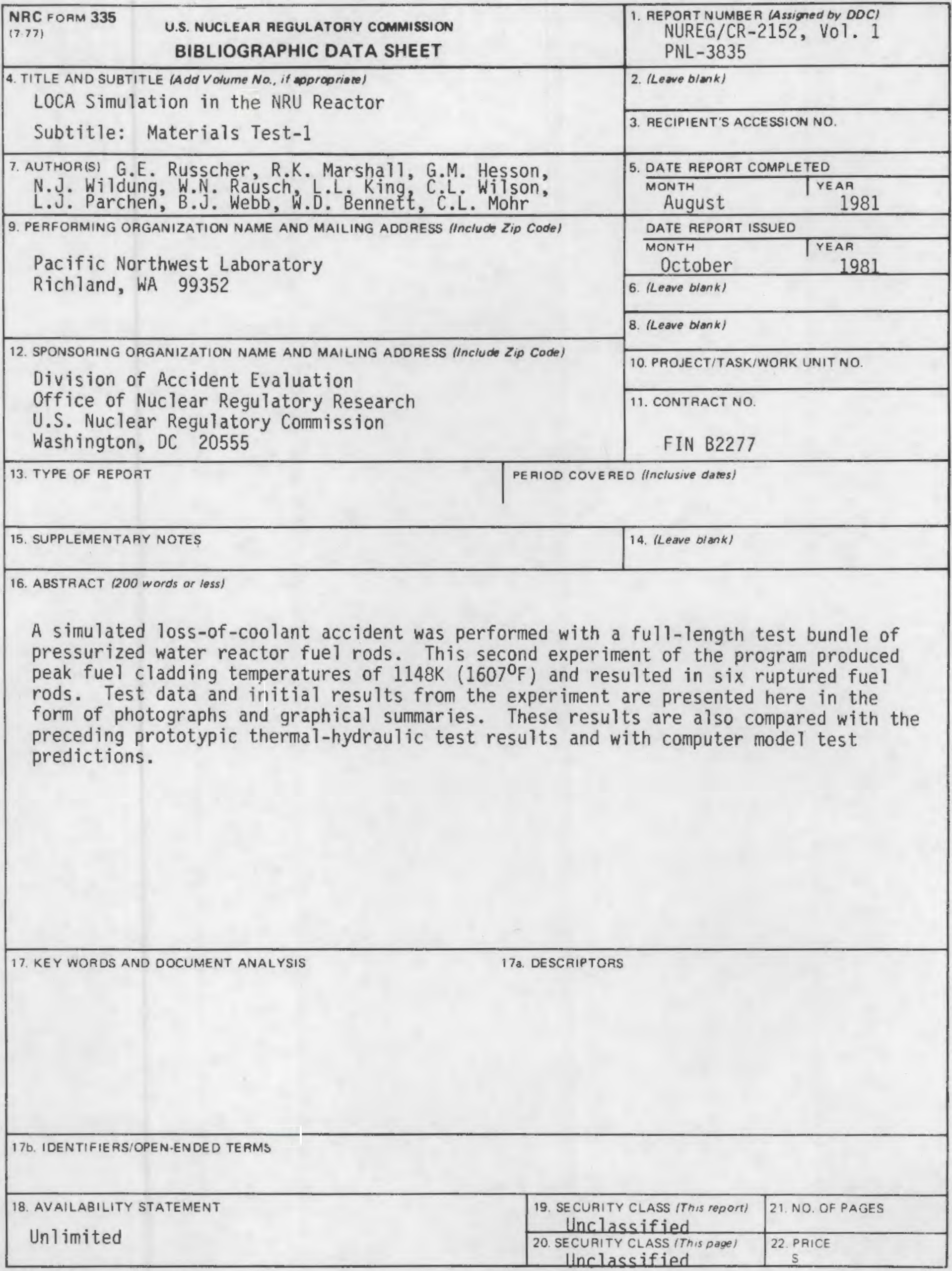


